UNIVERSIDADE FEDERAL DE SÃO PAULO

ESCOLA DE FILOSOFIA, LETRAS E CIÊNCIAS HUMANAS

BRUNO DOS SANTOS JOAQUIM

AS TDIC NA EDUCAÇÃO DE JOVENS E ADULTOS: ESTUDO DE CASO DA FORMAÇÃO CONTINUADA EM SERVIÇO DE PROFESSORES DA EJA PARA O USO EDUCACIONAL DAS TECNOLOGIAS DIGITAIS DA INFORMAÇÃO E COMUNICAÇÃO

GUARULHOS 


\title{
AS TDIC NA EDUCAÇÃO DE JOVENS E ADULTOS: ESTUDO DE CASO DA FORMAÇÃO CONTINUADA EM SERVIÇO DE PROFESSORES DA EJA PARA O USO EDUCACIONAL DAS TECNOLOGIAS DIGITAIS DA INFORMAÇÃO E COMUNICAÇÃO
}

\begin{abstract}
Dissertação de Mestrado apresentada ao Programa de Pós-Graduação em Educação da Escola de Filosofia, Letras e Ciências Humanas da Universidade Federal de São Paulo, sob orientação da Prof. ${ }^{a}$ Dr. ${ }^{a}$ Lucila Maria Pesce de Oliveira, como requisito para obtenção do título de Mestre em Educação.
\end{abstract}

\section{GUARULHOS}


Joaquim, Bruno dos Santos.

As TDIC na Educação de Jovens e Adultos: estudo de caso da formação continuada em serviço de professores da EJA para o uso educacional das tecnologias digitais da informação e comunicação / Bruno dos Santos Joaquim. Guarulhos, 2016.

$263 f$.

Dissertação (Mestrado em Educação) - Universidade Federal de São Paulo, Escola de Filosofia, Letras e Ciências Humanas, 2016.

Orientação: Prof. ${ }^{a}$ Dr. ${ }^{a}$ Lucila Maria Pesce de Oliveira

1. Educação de Jovens e Adultos. 2. Tecnologias Digitais da Informação e Comunicação. 3. Formação continuada de professores. 4. Formação de professores em serviço. 5. Cibercultura. I. Pesce, Lucila.

II. Título 


\section{AS TDIC NA EDUCAÇÃO DE JOVENS E ADULTOS: ESTUDO DE CASO DA FORMAÇÃO CONTINUADA EM SERVIÇO DE PROFESSORES DA EJA PARA O USO EDUCACIONAL DAS TECNOLOGIAS DIGITAIS DA INFORMAÇÃO E COMUNICAÇÃO}

Dissertação de Mestrado apresentada ao Programa de Pós-Graduação em Educação da Escola de Filosofia, Letras e Ciências Humanas da Universidade Federal de São Paulo, sob orientação da Prof. ${ }^{a}$ Dr. ${ }^{a}$ Lucila Maria Pesce de Oliveira, como requisito para obtenção do título de Mestre em Educação.

Guarulhos, 16 de dezembro de 2016.

Prof. ${ }^{a}$ Dr. ${ }^{a}$ Lucila Maria Pesce de Oliveira - UNIFESP (Orientadora)

Prof. ${ }^{a}$ Dr. ${ }^{a}$ Claudia Lemos Vóvio - UNIFESP (Titular Interno)

Prof. ${ }^{a}$ Dr. ${ }^{a}$ Maria da Graça Moreira da Silva - PUC/SP (Titular Externo)

Prof. ${ }^{a}$ Dr. ${ }^{a}$ Maria Elizabeth Bianconcini de Almeida - PUC/SP (Suplente Externo) 
Dedico esse trabalho aos meus pais e à memória de Zê, de Dona Neide e de Seu Macário, pelo importante papel na minha formação. 


\section{AGRADECIMENTOS}

Agradeço a minha família, em especial, meus pais, Marcos e Rosângela, a minha esposa, Fani, e a minha sogra Maria Jovem, pela presença em minha vida e apoio irrestrito aos meus estudos e minhas realizações pessoais.

Agradeço à minha orientadora, Prof. ${ }^{a}$ Dr. ${ }^{a}$ Lucila Pesce, pela amizade e pela competência, além do rigor como pesquisadora e orientadora de todo processo de pesquisa. Minha sincera gratidão pelos conselhos e pela paciência.

Agradeço à banca examinadora, Prof. ${ }^{a}$ Dr. ${ }^{a}$ Claudia Lemos Vóvio e Prof. ${ }^{a}$ Dr. ${ }^{a}$ Maria da Graça Moreira da Silva, por aceitarem o convite e por colaborarem com suas precisas intervenções durante a qualificação.

Agradeço aos professores do Programa de Pós-Graduação em Educação da Universidade Federal de São Paulo e a Prof. ${ }^{a}$ Dr. ${ }^{a}$ Maria Clara Di Pierro pelas aulas e pelo apoio ao meu processo de formação como pesquisador.

Agradeço a direção, coordenação e equipe docente do CEEJA analisado nesta pesquisa pelo apoio permanente ao meu trabalho como coordenador, como formador e como pesquisador.

Agradeço especialmente aos sujeitos de pesquisa por terem cedido seu tempo livre, tão escasso na profissão docente, para contribuir com este trabalho.

Agradeço aos colegas de mestrado e de profissão pelas palavras de incentivo e pelas constantes trocas de experiências e ideias, em especial aos amigos do Grupo de Pesquisa LEC: Linguagem, Educação e Cibercultura, os parceiros Paulo Luiz Vieira, Geane Carneiro, Fernando Dias, Valter Pedro, Silvia Nogueira e Lucas Marfim.

Enfim, agradeço a todos aqueles que, de maneira direta ou indireta, tornaram possível a realização deste trabalho. 
Vista criticamente, a tecnologia não é senão a expressão natural do processo criador em que os seres humanos se engajam no momento em que forjam o seu primeiro instrumento com que melhor transformam o mundo.

Paulo Freire (1921-1997) 
JOAQUIM, Bruno dos Santos. As TDIC na Educação de Jovens e Adultos: estudo de caso da formação continuada em serviço de professores da EJA para o uso educacional das Tecnologias Digitais da Informação e Comunicação. 2016. 263p. Dissertação. Mestrado em Educação. Universidade Federal de São Paulo.

\section{RESUMO}

A presente pesquisa qualitativa assume a abordagem metodológica do estudo de caso do tipo educacional. O objetivo geral consiste em compreender se e como o curso de formação de professor "Mídias Digitais na Educação de Jovens e Adultos", realizado em um Centro Educacional de Educação de Jovens e Adultos (CEEJA), contribuiu para o repensar da prática docente, amparado pela utilização crítica das Tecnologias Digitais da Informação e da Comunicação (TDIC), de modo a empoderar os professores, ao situar sua prática em uma perspectiva autoral. O estudo busca em documentos e nos discursos docentes: a) compreender o que fundamenta as escolhas na organização das oficinas planejadas pelos professores após o curso em tela; b) discutir suas possibilidades e seus limites para a formação docente, no que se refere ao uso educacional das TDIC e às especificidades presentes na educação de jovens e adultos (EJA); c) refletir acerca das contribuições dos conceitos de inclusão digital e do empoderamento, na acepção freireana, para o campo da EJA. O marco teórico ergue-se na intersecção de três campos conceituais: a) a formação continuada de professores em serviço e centrada na escola, a partir de uma perspectiva crítico-reflexiva; b) o uso educacional das TDIC a partir de uma concepção não instrumental, que visa à inclusão digital como meio para o empoderamento (na acepção freireana) de professores da EJA; c) a mudança no paradigma compensatório, historicamente intrínseco à EJA no Brasil, no caminhar gradual para uma concepção da modalidade fundamentada no paradigma da educação ao longo da vida. Compõem os dados desta pesquisa a análise documental do projeto político-pedagógico da escola, do plano do curso, elaborado e ministrado pelo pesquisador enquanto atuava como professor coordenador do CEEJA investigado, e dos planos de oficinas elaborados pelos professores ao final do curso de formação, além da análise temática de conteúdo dos depoimentos de sete sujeitos participantes do curso, sendo seis professores e um coordenador, entrevistados por meio de questionário semiestruturado. Os achados revelam que houve avanços no repensar dos docentes sobre suas práticas, na medida em que há relatos de experiências práticas transformadas ou impulsionadas pelas discussões oferecidas pelo curso, mas, ao mesmo tempo, sugerem limites como os diferentes níveis de apropriação tecnológica 
dos docentes, havendo um pequeno grupo mais mobilizado na direção do uso educacional crítico e inovador das TDIC e outro ainda centrado em uma perspectiva instrumental e não autoral, erguida sobre uma incipiente alfabetização digital. Os dados revelam que o curso não atingiu a totalidade de seu objetivo. Todavia, há indícios que revelam a importância desta formação como encetamento de um processo de mobilização para o uso das TDIC na instituição. A discussão dos resultados sugere um grande desafio: o fortalecimento da fluência tecnológica dos docentes a partir de uma perspectiva crítica e autoral, para que os mesmos possam se empoderar cada vez mais, como autores da sua prática docente.

Palavras-chave: educação e comunicação; formação continuada de professores; educação de jovens e adultos; formação de professores em serviço; tecnologias digitais da informação e comunicação. 


\begin{abstract}
This qualitative research assumes the methodological approach of case study of educational type. The overall objective is to understand whether and how the course of teacher training "Digital Media on Youth and Adult Education" held in an Educational Center for Youth and Adult Education (CEEJA), contributed to the rethinking of teaching, supported by the critical use of Digital Technologies of Information and Communication (TDIC), in order to empower teachers to locate their practice in an authorial perspective. The study seeks documents and speeches teachers: a) understand what underlies the choices in the organization of workshops planned by teachers after the course; b) to discuss its possibilities and its limits on teacher training, with regard to the educational use of TDIC and specificities present in adult education (EJA); c) reflect on the contributions of the concepts of digital inclusion and empowerment, in Freire's accordance for the field of adult education. The theoretical basis stands at the intersection of three conceptual fields: a) continuing education of teachers in service and focused on school, from a critical and reflective perspective; b) the educational use of TDIC from a non-instrumental conception, aimed at digital inclusion as a means of empowerment (in Freire's sense) of adult education teachers; c) the change in compensatory paradigm historically intrinsic to adult education in Brazil, gradual walk to a conception of the mode based on the paradigm of education throughout life. Compose the data in this research document analysis of the political-pedagogical project of the school, of the course syllabus, developed and taught by the researcher while serving as a teacher coordinator CEEJA investigated, and workshops plans prepared by teachers at the end of the training course, in addition to the thematic content analysis of the testimonies of seven individuals course participants, six teachers and a coordinator, interviewed using semi-structured questionnaire. The findings of this research reveal that there have been advances in the rethinking of teachers about their practices, in that there are practical experience reports processed or boosted by discussions offered the course, but at the same time, suggest limits to the different levels of technological appropriation of teachers, there is a small group mobilized more toward the critical and innovative educational use of TDIC and another still centered on an instrumental and not authorial perspective, built on an incipient digital literacy. The data reveal that the course did not achieve its entire goal. However, there are indications that reveal the importance of training as a mobilizing a process of mobilization for the use of TDIC in the institution. The discussion suggests a challenge: strengthening technological fluency of
\end{abstract}


teachers from a critical and authorial perspective so that they can be empowered increasingly as authors of their teaching practice.

Keywords: education and communication; continued teacher training; adult education; teacher in-service training; digital technologies of information and communication. 


\section{SUMÁRIO}

INTRODUÇÃO

CAPÍTULO 1 - REVISÃO DE LITERATURA: DIÁLOGOS ENTRE EJA, TDIC E FORMAÇÃO DOCENTE. 29

1.1 Pesquisas sobre as TDIC na Educação de Jovens e Adultos ...................................................... 30

1.2 Pesquisas sobre a formação de professores para o uso pedagógico das TDIC............................. 39

CAPÍTULO 2 - A FORMAÇÃO CONTINUADA EM SERVIÇO DE PROFESSORES DA EJA PARA O USO PEDAGÓGICO DAS TDIC: DIÁLOGOS SOB UMA PERSPECTIVA CRÍTICOREFLEXIVA...... 56

2.1 A formação de professores na perspectiva crítica-reflexiva.. 57

2.2 A formação continuada em serviço. 62

2.3 A formação de professores para o uso educacional das Tecnologias Digitais da Informação e da Comunicação. 68

2.4 A formação de professores para a educação de jovens e adultos . 75

CAPÍTULO 3 - O USO EDUCACIONAL DAS TDIC: DIÁLOGOS SOBRE O EMPODERAMENTO FREIREANO A PARTIR DA INCLUSÃO DIGITAL ................................... 84

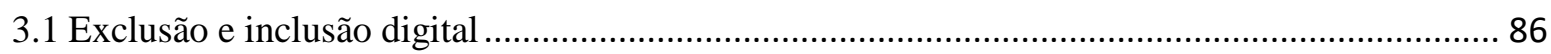

3.2 Letramento digital e empoderamento freireano ......................................................................... 94

CAPÍTULO 4 - EDUCAÇÃO DE JOVENS E ADULTOS: DO ENSINO SUPLETIVO COMPENSATÓRIO AO PARADIGMA DA EDUCAÇÃO AO LONGO DA VIDA........................ 99

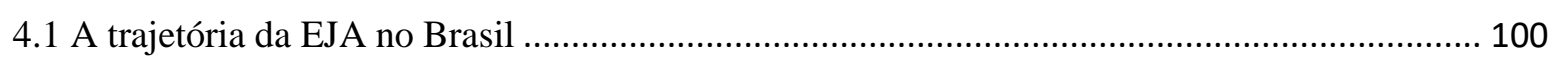

4.2 Ensino Supletivo: a EJA sob o paradigma compensatório ...................................................... 114

4.3 EJA para todos: o paradigma da educação ao longo da vida..................................................... 118

4.4 Histórico e Organização do CEEJA ……….............................................................................. 124

CAPÍTULO 5 - A PESQUISA DE CAMPO: DIÁLOGOS COM O FENÔMENO OBSERVADO . 130

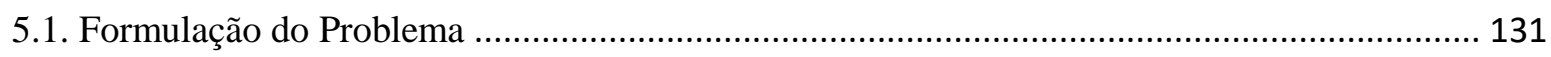

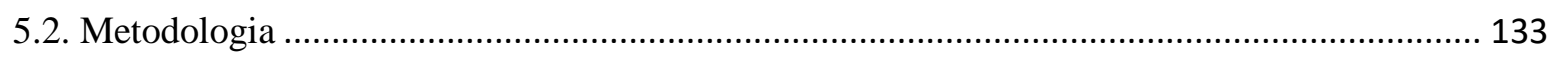

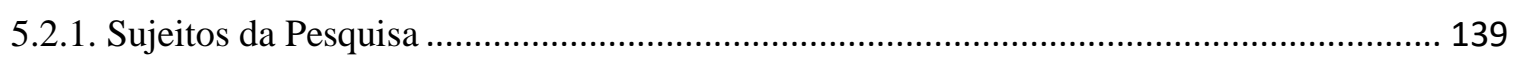

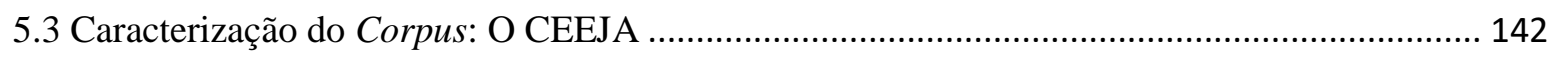

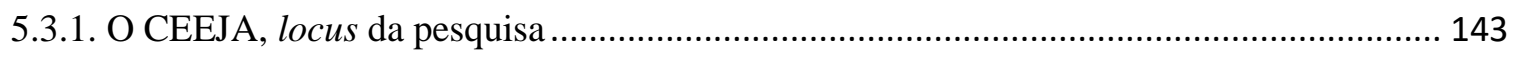

5.3.2 Curso de formação continuada em serviço centrada na escola: "Mídias Digitais na Educação

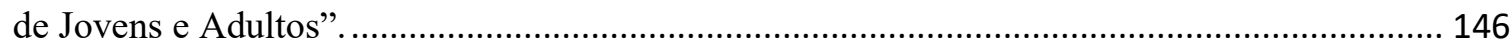

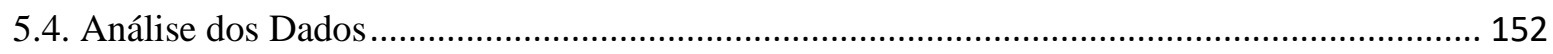

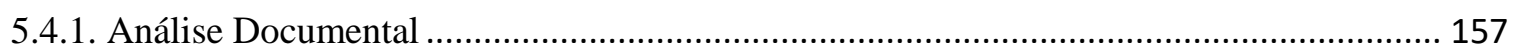




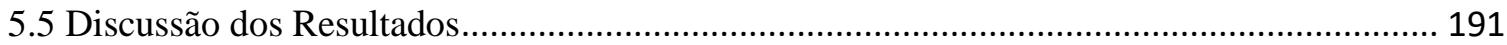

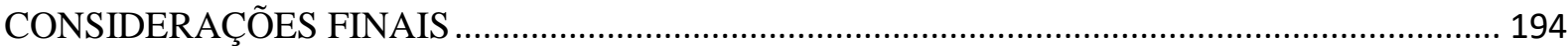

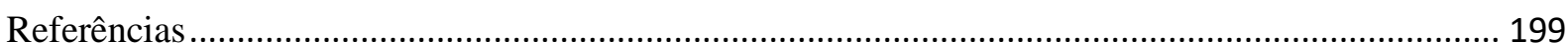

Apêndice A - Termo de Consentimento Livre e Esclarecido - TCLE................................................. 217

Apêndice B - Roteiro para entrevista semiestruturada - Professores.................................................. 219

Apêndice C - Roteiro para entrevista semiestruturada - Coordenador ............................................ 220

Anexo A - Plano de Curso "Mídias Digitais na Educação de Jovens e Adultos" ................................. 221

Anexo B - Assentimento da escola para realização da pesquisa ........................................................ 226

Anexo C - Transcrição da Entrevista - Prof. ${ }^{a}$ Rita de Cássia ............................................................. 227

Anexo D - Transcrição da Entrevista - Prof. ${ }^{a}$ Cláudia ...................................................................... 233

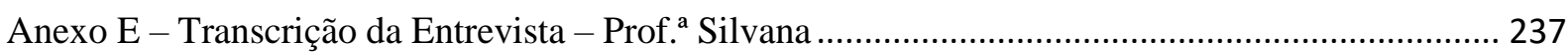

Anexo F - Transcrição da Entrevista - Prof. ${ }^{a}$ Maria............................................................................ 244

Anexo G - Transcrição da Entrevista - Prof. Luiz Roberto .......................................................... 247

Anexo H - Transcrição da Entrevista - Prof. Vinícius ...................................................................... 253

Anexo I - Transcrição da Entrevista - Prof. Renato ............................................................................ 258

Anexo J - Parecer do Comitê de Ética e Pesquisa - Unifesp................................................................224 


\section{LISTA DE QUADROS}

QUADRO 1 - Pesquisas sobre as TDIC na Educação de Jovens e Adultos 30

QUADRO 2 - Pesquisas sobre a formação de professores para o uso pedagógico das TDIC

QUADRO 3 - Critérios de seleção dos docentes entrevistados 140

QUADRO 4 - Síntese dos Padrões de Competência em TIC para Professores. 153

QUADRO 5 - Formações docentes no projeto político-pedagógico do CEEJA... 158

QUADRO 6 - Síntese dos planos de oficinas elaborados pelos professores. .164

QUADRO 7 - Síntese da análise dos planos de oficina... 170

QUADRO 8 - Síntese do nível de apropriação tecnológica dos sujeitos de pesquisa 180

QUADRO 9 - Síntese dos pontos fortes e fragilidades do curso "Mídias Digitais na Educação de Jovens e Adultos", segundo os entrevistados 187 


\section{LISTA DE ABREVIATURAS E SIGLAS}

ANPED - Associação Nacional de Pós-Graduação e Pesquisa em Educação

ATPC - Aula de Trabalho Pedagógico Coletivo

CAPES - Coordenação de Aperfeiçoamento de Pessoal de Nível Superior

CEAA - Campanha de Educação de Adultos Analfabetos

CEEJA - Centro Estadual de Educação de Jovens e Adultos

CEES - Centro Estadual de Educação Supletiva

CEJA - Centro de Educação de Jovens e Adultos

CENP - Coordenadoria de Estudos e Normas Pedagógicas

CES - Centro de Educação Supletiva

CGEB - Coordenadoria de Gestão da Educação Básica

CONAE - Conferência Nacional de Educação

CONFITEA - Conferência Internacional de Educação de Adultos

EAD - Educação a Distância

EFAP - Escola de Formação e Aperfeiçoamento de Professores

EJA - Educação de Jovens e Adultos

ENCCEJA - Exame Nacional para Certificação de Competências de Jovens e Adultos

ENEJA - Encontro Nacional de Educação de Jovens e Adultos

ENEM - Exame Nacional do Ensino Médio

EPJA - Educação de Pessoas Jovens e Adultas

E-PROINFO - Ambiente Colaborativo de Aprendizagem do PROINFO

FUNDAP - Fundação do Desenvolvimento Administrativo

FUNDEB - Fundo de Manutenção e Desenvolvimento da Educação Básica e de Valorização dos Profissionais da Educação

FUNDEF - Fundo de Manutenção e Desenvolvimento do Ensino Fundamental e Valorização do Magistério

GT - Grupo de Trabalho

HTPC - Hora de Trabalho Pedagógico Coletivo

ICT-CST - Information and Communication Technology - Competence Satandards for

Teachers (Tecnologia da Informação e Comunicação - Padrões de Competências para Professores)

IDEB - Índice de Desenvolvimento da Educação Básica

INAF - Indicador Nacional de Alfabetismo

INCRA - Instituto Nacional da Colonização e Reforma Agrária

INEP - Instituto Nacional de Estudos e Pesquisas Educacionais Anísio Teixeira 
LDB - Lei de Diretrizes e Bases

MEC - Ministério da Educação

MOBRAL - Movimento Brasileiro de Alfabetização

MOOC - Massive Open Online Courses (Cursos Online Abertos e Massivos)

MOVA - Movimento de Alfabetização de Jovens e Adultos

MST - Movimento dos Trabalhadores Rurais Sem Terra

PAS - Programa Alfabetização Solidária

PCNP - Professor Coordenador de Núcleo Pedagógico

PLANFOR - Plano Nacional de Qualificação do Trabalhador

PNE - Plano Nacional de Educação

PPP - Projeto Político Pedagógico

PROEJA - Programa Nacional de Integração da Educação Profissional com a Educação

Básica na Modalidade de Educação de Jovens e Adultos

PROEM - Programa de Extensão, Melhoria e Inovação do Ensino Médio do Paraná

PROINFO - Programa Nacional de Informática na Educação

PROJOVEM - Programação Nacional de Inclusão de Jovens

PRONATEC - Programa Nacional de Acesso ao Ensino Técnico e Emprego

PRONERA - Programa Nacional de Educação na Reforma Agrária

PROUCA - Programa Um Computador por Aluno

SCIELO - Scientific Electronic Library Online (Biblioteca Eletrônica Cientifica Online)

SE - Secretaria de Educação

SEA - Serviço de Educação de Adultos

SECADI - Secretaria de Educação Continuada, Alfabetização, Diversidade e Inclusão

SEE - Secretaria Estadual de Educação

SETEC - Secretaria de Educação Profissional e Tecnológica

SNJ - Secretaria Nacional de Juventude

TDIC - Tecnologias Digitais na Informação e da Comunicação

TCLE - Termo de Livre Consentimento e Esclarecido

TIC - Tecnologias da Informação e da Comunicação

UDESC - Universidade do Estado de Santa Catarina

UFSC - Universidade Federal de Santa Catarina

UNE - União Nacional dos Estudantes

UNEMAT - Universidade do Estado de Mato Grosso

UNESCO - Organização das Nações Unidas para a Educação, a Ciência e a Cultura

UNIFESP - Universidade Federal de São Paulo

USP - Universidade de São Paulo 


\section{INTRODUÇÃO}

Como professor da educação básica, desde 2008, diversas inquietações sempre pairaram minhas reflexões sobre a educação de jovens e adultos e suas peculiaridades. Quando em 2009, ainda recém-graduado em Ciências Sociais, entrei pela primeira vez em uma sala de aula de EJA, pude perceber que ali se corporizava um dos grandes entraves da educação básica no Brasil e que os desafios desta modalidade de ensino evidenciavam as tensões de um processo historicamente excludente de educação, especialmente pela presença de uma maioria de trabalhadores, pobres, negros, subempregados e excluídos do pleno exercício de sua cidadania, devido à baixa escolaridade.

No decorrer de minha trajetória, como professor de sociologia em escolas privadas e na rede pública estadual de São Paulo, outros questionamentos foram surgindo, a partir dos desafios oriundos do cotidiano da sala de aula. Entre eles, a questão da influência da cultura digital nas relações de comunicação entre alunos e professores e seu potencial transformador do processo de aprendizagem. Em 2013, como monografia de conclusão do curso de lato sensu do programa de pós-graduação em "Ética, Valores e Cidadania na Escola", da Escola de Artes e Ciências Humanas da Universidade de São Paulo, intitulado "Facebook e Educação: como alunos do Ensino Médio compartilham conhecimento na rede social", pude observar que estudantes e professores do ensino médio da escola investigada faziam uso de grupos na rede social Facebook, com o objetivo de compartilhar conhecimento e informação. Os resultados desta pesquisa indicaram que a cibercultura ${ }^{1} \mathrm{e}$ as redes sociais devem ser incorporadas ao processo educacional, por meio do uso pedagógico das Tecnologias Digitais da Informação e da Comunicação (TDIC) ${ }^{2}$, na medida em que os jovens estudantes do ensino médio já as reconheciam como um importante canal de comunicação e viam, por meio delas, a possibilidade de ampliar horizontes de aprendizagem.

Esses resultados me sugeriram algumas indagações que assinalam a necessidade de aprofundar a discussão sobre o uso pedagógico das TDIC. A principal refere-se à tímida participação de educadores nas relações estabelecidas pelos alunos no ciberespaço. A pergunta que deu guisa à conclusão da referida pesquisa foi: por que os professores não estão

\footnotetext{
${ }^{1}$ Cibercultura é entendida como "conjunto de técnicas (materiais e intelectuais) de práticas, de atitudes, de modos de pensamento e de valores que se desenvolvem juntamente com o crescimento do ciberespaço" (LÉVY, 1999, p. 17).

${ }^{2}$ Tecnologias Digitais da Informação e Comunicação (TDIC) podem ser entendidas como ferramentas que favorecem a utilização dos recursos tecnológicos, como o computador, o tablet, o celular e outros dispositivos midiáticos, com o objetivo de aprimorar a prática docente.
} 
efetivamente presentes nos grupos no Facebook e não fazem deles uma ferramenta para seu trabalho pedagógico?

Desta forma, minhas reflexões como pesquisador foram direcionadas a considerar a existência de um fosso tecnológico entre alunos e professores. Esse entendimento gerou a necessidade de agregar a temática do uso pedagógico das TDIC à formação de educadores. Parece-me, cada vez mais, fundamental refletir sobre como formar professores para o uso das tecnologias, a partir de uma perspectiva crítica, já que o apelo da sociedade capitalista é pela incorporação das TDIC, sob a égide de uma racionalidade técnica e instrumental (ADORNO e HORKHEIMER, 1985).

Em paralelo a esta pesquisa, no ano de 2013, comecei a atuar como professor de sociologia, em um Centro Estadual de Educação de Jovens e Adultos (CEEJA), onde exerci a função de professor coordenador pedagógico até 2016. Trata-se de uma unidade escolar da Secretaria Estadual de Educação de São Paulo, que atende exclusivamente alunos com idade igual ou superior a 18 anos. Organizados a partir da Resolução $n^{\circ}$. 77, de 6 de dezembro de 2011, os CEEJAs são caracterizados como instituições de ensino de organização didáticopedagógica diferenciada e funcionamento específico, destinados, preferencialmente, a alunos trabalhadores que não cursaram ou não concluíram as etapas da educação básica, correspondentes aos anos finais do Ensino Fundamental ou do Ensino Médio. O CEEJA nasceu da reestruturação do antigo modelo dos Centros Estaduais de Educação Supletiva (CEES), que já existiam em alguns municípios do estado há mais de duas décadas. Os CEEJA, segundo o artigo $2^{\circ}$ da referida resolução, devem oferecer uma modalidade de educação baseada no ensino individualizado, na presença flexível e na eliminação de disciplinas (SÃO PAULO, 2011).

Desta forma, apesar de minha pesquisa anterior investigar alunos do Ensino Médio inseridos na cibercultura e muito atentos ao uso das Tecnologias Digitais da Informação e Comunicação (TDIC) em seu cotidiano, ao ingressar no CEEJA, deparei-me com uma realidade completamente diferente. A multiplicidade de sujeitos das escolas/salas de aulas destinadas à educação de jovens e adultos representa um grande desafio. Por meio desta experiência, pude observar que um pequeno número de alunos fazia uso da sala de informática e das ferramentas de comunicação criadas pela escola: um website e uma página institucional na rede social Facebook. Ao mesmo tempo, constatei um enorme contingente de alunos, de diferentes idades, que não dominava as mais básicas ferramentas das TDIC ou as 
utilizam de forma limitada e, portanto, não possuem acesso à "vivência plena da cultura digital”, na expressão de Bonilla (2010).

A mesma percepção aplicava-se aos docentes do CEEJA, já que poucos faziam uso de estratégias ativas com uso das TDIC em suas práticas de atendimento individualizado ou em suas oficinas. Alguns possuíam certa dificuldade em fazer uso de ferramentas simples da informática, enquanto outros faziam apenas uso pessoal e, aparentemente, não incorporavam as TDIC em suas práticas pedagógicas.

Diante destas percepções, enquanto professor coordenador e pesquisador do campo, vi-me diante do desafio de promover na escola um curso de formação voltado para o uso das TDIC nas práticas docentes. No mesmo período em que assumi a função de professor coordenador também ingressei no Programa Pós-Graduação em Educação da Universidade Federal de São Paulo e inclui o curso de formação em meu projeto de pesquisa. Somavam-se, assim, três papéis que se coadunam, mas que, visando sua objetividade, não se confundem ao longo da pesquisa: o papel de coordenador do CEEJA, o papel de formador dos docentes do CEEJA e o papel de pesquisador do campo das TDIC.

Neste contexto, em um trabalho de parceria com outro professor coordenador da mesma escola, nasceu a proposta do curso "Mídias Digitais na Educação de Jovens e Adultos" que, de acordo com seu plano (ANEXO A), visava mobilizar o corpo docente da escola para o uso pedagógico das Tecnologias Digitais da Informação e da Comunicação (TDIC), a partir de uma visão crítica dessas ferramentas e tendo a educação de pessoas adultas como foco central. O curso é planejado, primeiramente, para atender a uma demanda constatada pelo olhar de quem, naquele momento, acabara de assumir a posição de coordenação da equipe pedagógica do CEEJA. Ao mesmo tempo, o curso situou-se como corpus de investigação da dissertação de mestrado.

A presente pesquisa consubstancia-se como um estudo de caso deste curso de formação continuada de professores deste CEEJA. Esta formação fez uso de parte do tempo destinado à formação dos professores em serviço para promover a capacitação e, acima de tudo, a reflexão sobre o uso pedagógico das TDIC, tendo em vista sua especificidade em atender exclusivamente alunos adultos e tomando como perspectiva a promoção de uma educação não compensatória e voltada para a promoção da inclusão digital e, por conseguinte, ao empoderamento, na acepção freireana (FREIRE e SHOR, 1986).

O conceito de empoderamento, na perspectiva de Paulo Freire, refere-se a um processo de ação social no qual os indivíduos tomam posse de suas próprias vidas pela interação com 
outros indivíduos, gerando pensamento crítico em relação as suas condições de vida, favorecendo a construção da capacidade pessoal e social e possibilitando a transformação de relações sociais de poder. Trata-se de um conceito que ultrapassa a esfera individual de emancipação, mas que diz respeito à transformação da sociedade como um todo (FREIRE e SHOR, 1986).

O objeto de pesquisa, desta forma, consubstancia-se na percepção dos docentes sobre o curso "Mídias Digitais na Educação de Jovens e Adultos", corpus de investigação. O curso foi realizado entre os meses de abril e maio de 2015, com cinco encontros realizados durante as Aulas de Trabalho Pedagógico Coletivo ${ }^{3}$ (ATPC) da escola. De acordo com seu plano, o objetivo do curso foi mobilizar os docentes do CEEJA para a inovação de suas práticas a partir das TDIC e conduzir a ação para o planejamento e realização de oficinas com uso das tecnologias.

O desenho do processo de formação em tela partiu de três premissas que serão discutidas a partir do referencial teórico exposto, ao longo da pesquisa. São elas:

a) O uso pedagógico das TDIC, para que ofereça a possibilidade de contribuir para a inclusão digital e para o empoderamento dos sujeitos (na acepção freireana), precisa ser compreendido a partir de uma perspectiva crítica, isto é, afastando-se do paradigma instrumental hegemônico na atual sociedade capitalista.

b) A formação crítico-reflexiva de professores precisa compreender a escola como seu locus formativo privilegiado, para que possa efetivamente situar os professores em uma perspectiva autoral.

c) A educação de jovens e adultos deve ser compreendida a partir de uma perspectiva não compensatória e, portanto, ligada ao novo paradigma da educação ao longo da vida e voltada para a emancipação dos grupos sociais.

Busco investigar, junto aos professores envolvidos na formação, se e como o curso contribuiu para a promoção das aludidas práticas autorais, que se valem das TDIC e para o empoderamento deste grupo social, por meio da análise dos depoimentos colhidos e de análise documental.

A questão da formação docente, se não for vista como a panaceia de todos os males da educação ou como a profusão de teorias da moda, pode ser um importante espaço de consolidação da identidade profissional do professor. "Mais do que um lugar de aquisição de

\footnotetext{
${ }^{3}$ Segundo Documento Orientador n ${ }^{\circ} 10$ de 2014, da CGEB, da Secretaria Estadual de Educação de São Paulo, “as Aulas de Trabalho Pedagógico Coletivo deverão ser utilizadas para reuniões e outras atividades pedagógicas e de estudo, de caráter coletivo, organizadas pelo estabelecimento de ensino" (SÃO PAULO, 2014, p.17).
} 
técnicas e de conhecimentos, a formação de professores é o momento-chave da socialização e da configuração profissional" (NÓVOA, 1995, p.18). É preciso, neste sentido, pensar a formação de professores em seu aspecto coletivo, a partir de uma perspectiva crítica e reflexiva.

Imbricada à cibercultura, a passagem do século XX para o XXI tem sido marcada pelo avanço do ciberespaço e pela transformação da relação entre o ser humano e o conhecimento. A busca por conhecimento está hoje marcada cada vez mais pela tecnologia, pela velocidade e pelo "saber fazer" (LÉVY, 1999). A produção e o compartilhamento de informação e conhecimento, assim como as demais práticas sociais contemporâneas, já não são mais viáveis senão pela fluidez das Tecnologias Digitais da Informação e da Comunicação (TDIC).

De acordo com Adorno e Horkheimer (1985), no entanto, a perspectiva crítica é a premissa para superar a égide de uma racionalidade técnica e instrumental dominante na sociedade capitalista industrial. A internet pode "revolucionar as abordagens educacionais tradicionais; ou ser utilizada para complementar ou subsidiar os processos de transmissão de informação que ainda persistem na grande maioria das escolas" (VALENTE, 2002, p. 132). O impacto transformador das TDIC na educação só será viável se estiver em confluência com a formação de professores para seu uso educacional, abrangendo todas as suas possibilidades de transformação e emancipação dos sujeitos, e não seu uso meramente instrumental.

Trata-se, portanto, de também compreender a formação de professores para o uso educacional das TDIC de forma crítica e reflexiva. Dentro desta concepção, Brito (2006) entende que a formação de professores para o uso educacional das TDIC deve ser pensada de forma desvinculada da ideia de tecnologia como objeto ou ferramenta, para que o professor “entenda a tecnologia como instrumento de intervenção na construção da sociedade democrática, contrapondo-se a qualquer tendência que o direcione ao tecnicismo, a coisificação do saber e do ser humano" (BRITO, 2006, p.17).

A perspectiva da formação de professor sugerida por estes autores contrapõe-se à "tendência de reduzir os professores ao status de técnicos especializados dentro da burocracia escolar, cuja função, então, torna-se administrar e implementar programas curriculares" (GIROUX, 1997, p. 158).Trata-se de uma perspectiva crítico-reflexiva que supõe o professor como intelectual transformador, refuta a concepção instrumental e técnica da docência e valoriza os saberes mobilizados pelos docentes: os saberes de uma prática reflexiva, os saberes de uma teoria especializada e os saberes de uma militância política (NÓVOA, 1999). 
Os programas de formação de professores, sejam de formação inicial ou continuada, possuem, de modo geral, claras deficiências científicas e pobreza conceitual. "A adequada formação do professor não pode ser imaginada como a simples e direta aplicação à situação de ensino de um saber teórico" (AZANHA, 2006, p. 57). Neste sentido, um caminho viável é “encontrar processos que valorizem a sistematização dos saberes próprios, a capacidade para transformar a experiência em conhecimento e a formalização de um saber profissional de referência” (NÓVOA, 1999, p. 18).

O uso educacional das TDIC concebido em uma perspectiva não instrumental pressupõe também a existência de professores autores que possuam o compartilhamento como princípio de ação, isto é, como atores participantes do sistema educacional (PRETTO e ASSIS, 2008). A própria expansão do ciberespaço é consequência do compartilhamento, na medida em que a dinâmica da cibercultura, segundo Lévy (1999), é resultado da construção do conhecimento que ocorre por meio de uma mobilização efetiva das competências de milhões de usuários da internet.

As contribuições das TDIC na educação podem ser mais efetivas se estiverem em confluência com o uso de metodologias mais ativas, formação de professores para seu uso educacional e crítico e políticas públicas que garantam infraestrutura para as escolas. É preciso sempre ter clareza de que "a tecnologia per se não parece garantir sucesso no aprendizado" (LAVINAS e VEIGA, 2013, p.3).

Para além desses questionamentos acerca da formação de professores para uso pedagógico das TDIC, outro campo de debates necessário para dialogar com a presente pesquisa é o da educação de jovens e adultos. É preciso pensar nas implicações de um trabalho com as TDIC em uma escola/sala de aula de EJA, a partir do conceito de inclusão digital. Trata-se de um conceito-chave para a reflexão sobre o acesso da população economicamente desfavorecida à vivência plena da cibercultura. "Como a escola deve ser espaço-tempo de crítica dos saberes, valores e práticas da sociedade em que está inserida, é da sua competência, hoje, oportunizar aos jovens a vivência plena das redes digitais" (BONILLA, 2010, p. 44). A escola é entendida, portanto, como locus primeiro e natural da inclusão digital: dimensão importante da inclusão social, na contemporaneidade.

Os mais diversos estudos sobre políticas públicas e modelos de inclusão digital, como Buzato (2008) e Lavinas e Veiga (2013) têm como foco os jovens e as crianças. Há, todavia, um enorme contingente de sujeitos já adultos que não foram incluídos no mundo digital e nem são lembrados pelas pesquisas do campo. Neste sentido, esta pesquisa propõe também a 
reflexão sobre a inclusão digital, e as discussões que por ela perpassam, na perspectiva das especificidades da educação de jovens e adultos. A discussão acerca da inclusão digital de adultos é decorrente do questionamento sobre a percepção que os professores desta modalidade fazem do uso pedagógico das TDIC.

Se a educação de jovens e adultos foi historicamente colocada em posição secundária em relação à educação de crianças e adolescentes, em uma abordagem mais ampla e sistêmica da educação, ela pode ser considerada "como uma das arenas importantes onde vêm se empreendendo esforços para a democratização do acesso ao conhecimento" (DI PIERRO et al., 2001, p. 58). Há basicamente três grandes entraves para a consolidação de uma identidade para a EJA e para a promoção da inclusão digital na modalidade, que devem ser levados em conta na construção deste projeto.

O primeiro refere-se à predominância da ideia de educação compensatória na educação de adultos. Esta visão está ligada à concepção do ensino supletivo, isto é, à ideia da reposição de estudos não realizados na infância e na adolescência.

Ao dirigir o olhar para a falta de experiência e conhecimento escolar dos jovens e adultos, a concepção compensatória nutre visões preconceituosas que subestimam os alunos, dificulta que os professores valorizem a cultura popular e reconheçam os conhecimentos adquiridos pelos educandos no convívio social e no trabalho (DI PIERRO, 2005a, p.1118).

Esta visão dificulta ações para a promoção da inclusão digital e o uso pedagógico das TDIC com o objetivo de inserção dos sujeitos no mundo digital, porque se limita apenas a reproduzir as práticas e o currículo das escolas regulares. Como ela representa um modelo de suplência, mais acelerado que a educação básica regular, é disponibilizado ainda menos tempo para que o aluno tenha contato com as tecnologias e possa, por meio dela, encontrar possibilidades de emancipação.

O currículo da educação de jovens e adultos também reproduz a perspectiva cientificista de toda a educação básica. Este é o segundo entrave para o acesso dos adultos não escolarizados às tecnologias, porque, nesta modalidade, o ensino mantém-se excessivamente "tecnicista e disciplinarista, o que dificulta o estabelecimento de diálogos entre experiências vividas, os saberes anteriormente tecidos pelos educandos e os conteúdos escolares" (OLIVEIRA, 2007, p.86). Na perspectiva crítica do uso das tecnologias, como dito, o diálogo e a construção coletiva do conhecimento devem ser os eixos centrais. Desta forma, o currículo engessado, o formalismo e a fragmentação dos saberes precisam ser superados para se almejar 
uma educação de adultos de qualidade, em que não faz sentido pressupor uma trajetória única para todos os sujeitos.

O terceiro entrave está relacionado ao processo de formação de professores para atuar na educação de jovens e adultos. Há, segundo Ribeiro (1999), ausência de programas de formação específica dos educadores que atuam nessa modalidade de ensino, resultando em uma transposição inadequada do modelo da educação básica regular. Este entrave implica dois outros problemas: a infantilização dos sujeitos e o surgimento de uma visão assistencialista da educação de jovens e adultos.

É possível perceber que o debate em torno do uso pedagógico das TDIC como meio de promoção da inclusão digital dialoga com a discussão acerca da especificidade da educação de jovens e adultos. Enquanto esta propõe a superação da perspectiva compensatória existente no modelo supletivo, aquele enfrenta a necessidade de superar a perspectiva instrumental do uso das tecnologias. Deste modo, urge a necessidade de aproximar estes dois campos de reflexão pedagógica ao campo da formação de professores.

Estes pressupostos teóricos contribuem para a compreensão do corpus de pesquisa e para a promoção de reflexões colegiadas sobre as práticas docentes consubstanciadas na realidade da escola. Avaliar a contribuição do curso em tela para esse processo reflexivo é o foco central desta pesquisa, pelo qual acredito poder contribuir tanto para o debate acadêmico quanto para a realidade da escola em que sou atuante.

Esta pesquisa articula-se ao projeto de pesquisa "Políticas de inclusão digital: desdobramentos na educação básica e na formação de professores", em andamento, coordenado pela Prof. ${ }^{a}$ Dr. ${ }^{a}$ Lucila Pesce, que se volta às políticas de inclusão digital e seus desdobramentos no campo da educação básica e no campo da formação de professores. $\mathrm{O}$ projeto supracitado abarca: a) o estudo das normativas legais sobre formação de professores para o uso pedagógico das tecnologias digitais da informação e comunicação (TDIC); b) pesquisas exploratórias de programas de inclusão digital voltados às escolas públicas brasileiras; c) investigações de programas e/ou ações de formação de professores da educação básica para o uso educacional das TDIC. A pesquisa ora apresentada articula-se ao terceiro flanco do projeto de pesquisa em andamento pela Prof. ${ }^{a}$ Dr. ${ }^{a}$ Lucila Pesce.

No tocante à justificativa científica, a presente pesquisa visa dar sua contribuição para o campo de investigação da formação de professores para o uso pedagógico das mídias digitais e também para o campo de discussão acerca da educação de jovens e adultos. É exatamente na intersecção destes três campos da pesquisa educacional que ele se acondiciona, 
com o objetivo de contribuir para o debate em torno da evolução qualitativa da educação no Brasil.

A justificativa de natureza pessoal e profissional envolve minha trajetória, como professor da EJA e ex-coordenador pedagógico do CEEJA em tela. Neste percurso pude me sensibilizar diante da indiferença das políticas públicas voltadas à formação de pessoas adultas, além de perceber no cotidiano da EJA muitas ações ainda pautadas por uma visão compensatória e/ou infantilizada desta modalidade de ensino.

Outra percepção permanente refere-se ao uso das TDIC, a partir de uma perspectiva instrumental na escola. Enquanto coordenador pedagógico, assumi o compromisso de mobilizar o corpo docente, a fim de compreender as tecnologias a partir de uma ótica mais crítica e comprometida com a inclusão digital, em seu sentido amplo. Além disso, a falta de engajamento dos professores em relação ao uso das tecnologias motivou-me a promover a formação e a investigar suas possíveis consequências.

A pesquisa também se justifica do ponto de vista acadêmico. Em busca realizada nos principais indexadores de dissertações, teses e revistas científicas do campo educacional detectou-se a escassez de trabalhos sobre a formação de professores para o uso pedagógico das TDIC ou no campo da intersecção entre as TDIC e a educação de jovens e adultos. $\mathrm{O}$ levantamento bibliográfico se deu dentro do recorte temporal de sete anos: entre 2007 (ano em que a EJA passou a ser contemplada pelo financiamento do FUNDEB $^{4}$ ) e 2014. Foram selecionadas 14 pesquisas acerca do uso de novas tecnologias na EJA e 25 que tratam da formação de professores para o uso das TDIC. Três tendências foram observadas por meio desta revisão de literatura: a) há poucos estudos sobre a formação de professores para o uso das TDIC no contexto da EJA; b) há poucos trabalhos que apresentem experiências bemsucedidas de formação continuada de professores para o uso educacional das TDIC; c) os estudos apresentados indicam que, mais do que nunca, é necessário superar a perspectiva técnica e instrumental na integração das TDIC às práticas escolares e substituí-la por uma visão mais crítica, reflexiva e que se ampare na constituição do professor como profissional da educação que pode desempenhar sua função, erguido em meio à perspectiva autoral.

Esta pesquisa tem como objetivo geral compreender se e como o curso de formação “Mídias Digitais na Educação de Jovens e Adultos", realizado em um CEEJA no ano de 2015,

\footnotetext{
${ }^{4}$ O Fundo de Manutenção e Desenvolvimento da Educação Básica e de Valorização dos Profissionais da Educação (FUNDEB) entra em vigor em 2007 em substituição ao Fundo de Manutenção e Desenvolvimento do Ensino Fundamental e Valorização do Magistério (FUNDEF). O FUNDEB foi celebrado principalmente pelos setores educacionais por incluir a Educação Infantil, o Ensino Médio e a Educação de Jovens e Adultos (EJA), modalidades até então alijadas do FUNDEF na distribuição de recursos federais.
} 
contribuiu para o repensar da prática docente, amparado pela utilização crítica das TDIC, de modo a empoderar os professores, ao situar sua prática em uma perspectiva autoral. Deste objetivo, considerando o desenvolvimento do curso em tela, emanam três objetivos específicos:

1. Analisar no projeto político-pedagógico do CEEJA em tela, nos planos de oficina e nos discursos dos professores entrevistados o que fundamenta suas escolhas na organização das oficinas planejadas após o curso "Mídias Digitais na Educação de Jovens e Adultos".

2. Discutir as possibilidades e os limites do curso em tela para a formação docente, no que se refere ao uso educacional das TDIC e às especificidades presentes na educação de jovens e adultos.

3. Refletir acerca das contribuições dos conceitos de inclusão digital e do empoderamento, na acepção freireana, para o campo da educação de jovens e adultos.

Estes objetivos imbricam-se ao problema de pesquisa: em que medida e de que modo o curso de formação "Mídias Digitais na Educação de Jovens e Adultos", realizado em um CEEJA no ano de 2015, contribuiu para o repensar da prática docente, amparado pela utilização crítica das TDIC, de forma a empoderar os professores, ao situar sua prática em uma perspectiva autoral?

Esta pesquisa qualitativa adota a metodologia do estudo de caso do tipo educacional, compreendendo que esta pode contribuir para a busca por respostas. Ainda que a abordagem da pesquisa-ação possa parecer mais adequada ao lançar vista sobre o objeto, de acordo com Gil (2002), esta tipologia tem sido alvo de grandes controvérsias, na medida em que o envolvimento ativo do pesquisador e a ação, por parte das pessoas ou grupos envolvidos no problema, podem comprometer a objetividade que caracterizam os procedimentos científicos. Evidentemente, estou profundamente envolvido com a realidade investigada, em um triplo papel de coordenador-formador-pesquisador; no entanto, compreendo o estudo de caso educacional como o mais apropriado, exatamente por ajudar na busca pelo distanciamento necessário para a compreensão do objeto.

O estudo de caso educacional é quando muitos pesquisadores, usando estudo de caso, estão preocupados não com teoria social nem com julgamento avaliativo, mas com a compreensão da ação educativa. Eles buscam enriquecer o pensamento e o discurso dos educadores pelo desenvolvimento de teoria educacional (STENHOUSE, apud ANDRÉ, 2005). 
Desta forma, busco analisar em profundidade o fenômeno em questão e não somente deter-me a descrevê-lo, mas, sobretudo, explicá-lo (GIL, 2002).

Compõem os dados desta pesquisa o projeto político-pedagógico da escola, o plano do curso "Mídias Digitais na Educação de Jovens e Adultos" e os planos de oficinas elaborados pelos professores, ao final do curso de formação, além dos depoimentos de sete sujeitos participantes do curso. Tais documentos são analisados com base no arcabouço teórico dos campos de formação de professores, uso pedagógico das TDIC e educação de jovens e adultos, além dos Padrões de Competência em TIC para professores (ICT-CST) (UNESCO, 2009a; 2009b),

Os achados da análise documental permitem perceber uma visão ainda limitada sobre a relação entre a cultura digital e o conhecimento no Projeto Político-Pedagógico (PPP) da escola, mas sugerem forte proximidade na perspectiva sobre EJA, por compreendê-la a partir do paradigma da educação ao longo da vida. O plano de curso sugere estreita relação com as perspectivas teóricas, enquanto os planos de oficinas elaborados pelos docentes demonstram resultados parcialmente positivos, em relação à influência do curso de formação sobre sua percepção do uso educacional das TDIC, como apresentado no decorrer da análise.

Os dados para análise temática do conteúdo (BARDIN, 1977) foram obtidos através de entrevistas semiestruturadas de seis dos 27 professores, além do professor coordenador que, em parceria comigo, colaborou com o planejamento e a execução dos encontros promovidos pela formação "Mídias Digitais na Educação de Jovens e Adultos". O critério de seleção dos participantes os dividiu em dois grupos: o primeiro corresponde aos professores que executaram seus planos de oficinas, tendo por base as discussões promovidas nas ATPC, do qual foram selecionados três participantes da pesquisa, um de cada área de conhecimento ${ }^{5}$ (a- códigos e linguagens, b- ciências humanas e suas tecnologias, c- ciências da natureza e suas tecnologias); o segundo grupo representa os professores que até o momento da seleção ainda não vieram a executar a oficina planejada como atividade de conclusão do processo formativo, do qual também foram selecionados um professor de cada grande área do conhecimento. Estes sete participantes foram entrevistados a partir de um roteiro semiestruturado (ANEXO B).

Os depoimentos dos docentes (ANEXOS C a I) são analisados por meio da Categoria A - Nível de apropriação tecnológica dos docentes e empoderamento - e Categoria B Pertinência e aproveitamento do curso.

\footnotetext{
${ }^{5}$ A estrutura de divisão das áreas de conhecimento corresponde ao Currículo Oficial do Estado de São Paulo, que se aplica à toda rede pública estadual, inclusive os CEEJA.
} 
Em relação à discussão dos resultados, é possível perceber que o curso "Mídias Digitais na Educação de Jovens e Adultos" contribui para o repensar docente sobre o uso pedagógico das TDIC, mas o nível de apropriação tecnológica é distinto entre os docentes e que o repensar em relação às TDIC na EJA ainda é incipiente. No entanto, apesar do curso não ter atingido a totalidade de seus objetivos, há dados que denotam a importância desta formação como o início de um processo de mobilização para o uso das TDIC na escola em tela.

Esta dissertação conta com a revisão de literatura, três capítulos teóricos e a pesquisa de campo, que abarca o delineamento metodológico, a caracterização do corpus, a análise dos dados e a discussão dos resultados.

A revisão de literatura compõe um levantamento de teses, dissertações e artigos, a partir de um recorte temporal de sete anos (2007-2014). Este capítulo procura estabelecer um diálogo entre esta pesquisa e outras publicações, tanto no campo de intersecção do uso pedagógico das TDIC e da Educação de Jovens e Adultos, quanto no campo da formação de professores para o uso educacional das mídias digitais.

O segundo capítulo trata da formação de professores, a partir da perspectiva críticoreflexiva, apoiado principalmente em Nóvoa (1995), Giroux (1997) e Tardif (2014), e sobre a formação continuada em serviço, com base em Canário (1999), Aquino e Mussi (2001) e Cunha e Prado (2010). Também define a perspectiva teórica no campo da formação de professores para o uso educacional das TDIC, com base em autores que defendem uma perspectiva crítica e autoral (BELLONI, 1998; BARRETO, 2002; BRITO, 2006; PRETTO e ASSIS, 2008; PESCE, 2014). Por fim, o capítulo trata da formação específica de docentes do campo da EJA, pautado no pensamento de Ribeiro (1999), Di Pierro (2005a), Arroyo (2006), Soares (2008) e Moura (2009).

O terceiro capítulo tem como objetivo tratar do letramento digital e do conceito de empoderamento, na perspectiva de Freire e Shor (1986), Bonilla (2010), Baquero (2012) e Pesce (2013a), além do conceito de inclusão digital, com base principalmente em Sorj e Guedes (2005) e Buzato (2008; 2010), buscando afastar-se da égide da racionalidade técnica e instrumental dominante (ADORNO e HORKHEIMER, 1985).

O quarto capítulo, por sua vez, pretende discutir a educação de jovens e adultos, a partir de uma perspectiva não compensatória, isto é, caminhando na direção do paradigma da educação ao longo da vida (ALHEIT e DAUSIEN, 2006; LIMA, 2007) e buscando articular a discussão com a urgência de inserir as TDIC nas práticas dos professores da EJA. Autores como Ribeiro (1999), Oliveira (2001), Di Pierro (2001; 2005) e Di Pierro e Haddad (2000; 
2015), situam-se como diretrizes teóricas para compreender a trajetória da modalidade no Brasil e os principais entraves para seu fortalecimento. Além disso, o capítulo dedica-se a tratar do modelo do CEEJA, dentro do contexto de formatação do ensino supletivo.

O quinto capítulo, que trata da pesquisa de campo, no tocante à metodologia utilizada para o desenvolvimento da pesquisa, procura caracterizar as premissas ontológicas e epistemológicas da pesquisa qualitativa (BOGDAN e BIKLEN, 1994; PESCE e ABREU, 2013). Além disso, o capítulo trata do processo de formulação do problema de pesquisa, da caracterização do corpus em análise, da análise dos dados e da discussão dos resultados. 


\section{CAPÍTULO 1 - REVISÃO DE LITERATURA: DIÁLOGOS ENTRE EJA, TDIC E FORMAÇÃO DOCENTE}

Com o objetivo de proceder a uma apropriação mais profunda do debate acadêmico acerca da formação de professores para o uso das TDIC no contexto da educação de jovens e adultos, foi realizado um levantamento de pesquisas científicas sobre o tema, focalizando os objetivos desses estudos, as metodologias utilizadas e os resultados alcançados. Foi realizado um recorte temporal das pesquisas desenvolvidas entre 2007 e 2014, considerando esses dados fundamentais para a contextualização do presente trabalho e necessários para a sua inserção no cenário investigativo.

O ano de 2007 serve de marco para este recorte temporal, por ser o ano de promulgação da lei 11.494/2007, que cria o Fundo de Manutenção e Desenvolvimento da Educação Básica e de Valorização dos Profissionais da Educação (FUNDEB), que entra em vigor, em substituição ao Fundo de Manutenção e Desenvolvimento do Ensino Fundamental e Valorização do Magistério (FUNDEF). O FUNDEB foi celebrado principalmente pelos setores educacionais (níveis e modalidades) alijados anteriormente do FUNDEF, principalmente a Educação Infantil, o Ensino Médio e a Educação de Jovens e Adultos (EJA). O reconhecimento da existência da EJA na distribuição de recursos da União, ainda que aquém da real necessidade e demanda da modalidade, impactou positivamente na visibilidade da EJA ante as políticas públicas (GOUVEA, 2008) e pode apresentar desdobramentos, para os estudos e pesquisas desenvolvidas no campo.

A pesquisa bibliográfica iniciou-se com a busca no banco de teses e dissertações da Coordenação de Aperfeiçoamento de Pessoal de Nível Superior (CAPES) e no Domínio Público e se estendeu pelo indexador de publicações acadêmicas Scientific Electronic Library Online - SciELO, anais das reuniões da Associação Nacional de Pós-Graduação e Pesquisa em Educação - ANPEd $^{6}$ e na plataforma de busca Google Acadêmico, estabelecendo como foco a formação de educadores para o uso educacional das Tecnologias Digitais da Informação e da Comunicação (TDIC), no contexto da educação de jovens e adultos.

Neste processo de busca foram utilizadas palavras-chave como: "formação de professores", “formação de educadores", “tecnologias digitais da informação e da

\footnotetext{
${ }^{6}$ Foram pesquisados os anais das reuniões nacionais da ANPEd entre os anos de 2004 e 2014, especificamente os Grupos de Trabalho (GT) 06 - Educação Popular; GT 08 Formação de Professores; GT 16 Educação e Comunicação; e GT 18 Educação de Pessoas Jovens e Adultas.
} 
comunicação (TDIC)", "tecnologias da informação e da comunicação", "educação de jovens e adultos (EJA)", "inclusão digital" e "empoderamento".

\subsection{Pesquisas sobre as TDIC na educação de jovens e adultos}

Em um primeiro cruzamento, buscaram-se teses, dissertações e artigos acadêmicos que tratassem do uso pedagógico das TDIC na educação de jovens e adultos, excluindo inicialmente a busca por trabalhos que se referem à formação dos professores para o uso das TDIC. O quadro abaixo apresenta 14 pesquisas acerca do uso de novas tecnologias na EJA.

Quadro 1 - Pesquisas sobre as TDIC na Educação de Jovens e Adultos

\begin{tabular}{|c|c|c|c|}
\hline Autor/Ano & Título & Instituiçãa & $\begin{array}{c}\text { Publicação } \\
\text { (Dissertação/Tese/Artigo }\end{array}$ \\
\hline $\begin{array}{l}\text { GONÇALVES, } \\
\text { Becky Henriette } \\
\text { (2007) }\end{array}$ & $\begin{array}{l}\text { O uso do computador, } \\
\text { a alfabetização e a pós- } \\
\text { alfabetização: o que } \\
\text { dizem educandos/as do } \\
\text { MOVA }\end{array}$ & $\begin{array}{l}\text { Universidade } \\
\text { Federal de São } \\
\text { Carlos }\end{array}$ & Dissertação: Educação \\
\hline $\begin{array}{c}\text { GOULART, Denise } \\
\text { (2007) }\end{array}$ & $\begin{array}{l}\text { Inclusão Digital na } \\
\text { terceira idade: a } \\
\text { virtualidade como } \\
\text { objeto e } \\
\text { reencantamento da } \\
\text { aprendizagem }\end{array}$ & $\begin{array}{c}\text { Pontifícia } \\
\text { Universidade } \\
\text { Católica do Rio } \\
\text { Grande do Sul }\end{array}$ & Dissertação: Educação \\
\hline $\begin{array}{l}\text { HIDALGO, Sivonei } \\
\text { (2007) }\end{array}$ & $\begin{array}{l}\text { A educação de jovens } \\
\text { e adultos no município } \\
\text { de Curitiba sob a ótica } \\
\text { de gênero e tecnologia }\end{array}$ & $\begin{array}{c}\text { Universidade } \\
\text { Tecnológica } \\
\text { Federal do Paraná }\end{array}$ & Dissertação: Tecnologia \\
\hline $\begin{array}{c}\text { GONTIJO, } \\
\text { Cynthia Rúbia } \\
\text { Braga } \\
\text { OLIVEIRA, Maria } \\
\text { Rita Neto Sales } \\
\text { (2008) }\end{array}$ & $\begin{array}{l}\text { Vozes docentes e } \\
\text { discentes sobre } \\
\text { condições, objetivos e } \\
\text { contribuições do uso } \\
\text { das TICs na EJA }\end{array}$ & $\begin{array}{l}\text { Centro Federal de } \\
\text { Educação } \\
\text { Tecnológica de } \\
\text { Minas Gerais }\end{array}$ & Artigo \\
\hline $\begin{array}{l}\text { NÁPOLES, Neusa } \\
\text { Nogueira (2008) }\end{array}$ & $\begin{array}{l}\text { O uso das tecnologias } \\
\text { da informação e } \\
\text { comunicação na } \\
\text { educação de jovens e } \\
\text { adultos: visão de } \\
\text { alunos e professores de } \\
\text { uma escola municipal } \\
\text { de Belo Horizonte } \\
\end{array}$ & $\begin{array}{l}\text { Centro Federal de } \\
\text { Educação } \\
\text { Tecnológica de } \\
\text { Minas Gerais }\end{array}$ & $\begin{array}{l}\text { Dissertação: Educação } \\
\text { Tecnológica }\end{array}$ \\
\hline $\begin{array}{l}\text { CRUZ, Regina } \\
\text { Maria Ribeiro } \\
\text { (2008) }\end{array}$ & $\begin{array}{c}\text { Limites e } \\
\text { possibilidades das } \\
\text { tecnologias na } \\
\text { educação de jovens e } \\
\text { adultos } \\
\end{array}$ & $\begin{array}{l}\text { Centro Federal de } \\
\text { Educação } \\
\text { Tecnológica de } \\
\text { Minas Gerais }\end{array}$ & $\begin{array}{l}\text { Dissertação: Educação } \\
\text { Tecnológica }\end{array}$ \\
\hline SANTOS, & 'Tá vendo aquele & Universidade & Dissertação: Educação \\
\hline
\end{tabular}




\begin{tabular}{|c|c|c|c|}
\hline$\overline{\text { Amaleide (2008) }}$ & $\begin{array}{l}\text { edifício moço?' - A } \\
\text { especificidade da } \\
\text { inclusão digital para } \\
\text { trabalhadores da } \\
\text { construção civil não } \\
\text { alfabetizados } \\
\end{array}$ & Federal da Bahia & \\
\hline $\begin{array}{l}\text { GONTIJO,Cynthia } \\
\text { Rúbia Braga (2008) }\end{array}$ & $\begin{array}{c}\text { Tecnologias de } \\
\text { informação e } \\
\text { comunicação na } \\
\text { educação de jovens e } \\
\text { adultos }\end{array}$ & $\begin{array}{l}\text { Centro Federal de } \\
\text { Educação } \\
\text { Tecnológica de } \\
\text { Minas Gerais }\end{array}$ & $\begin{array}{c}\text { Dissertação: Educação } \\
\text { Tecnológica }\end{array}$ \\
\hline $\begin{array}{l}\text { BRITO, Bianca } \\
\text { Maria Santana } \\
(\text { (2010) }\end{array}$ & $\begin{array}{l}\text { Jovens e Adultos em } \\
\text { Processo de } \\
\text { escolarização e as } \\
\text { tecnologias digitais: } \\
\text { quem usa, e a favor de } \\
\text { quem e para quê? }\end{array}$ & $\begin{array}{l}\text { Universidade de } \\
\text { São Paulo }\end{array}$ & Dissertação: Educação \\
\hline $\begin{array}{l}\text { COELHO, Lívia } \\
\text { Andrade (2011) }\end{array}$ & $\begin{array}{l}\text { As relações dos alunos } \\
\text { da EJA com as } \\
\text { tecnologias digitais: } \\
\text { implicações e } \\
\text { possibilidades na vida } \\
\text { de cada um. }\end{array}$ & $\begin{array}{c}\text { Universidade } \\
\text { Federal da Bahia }\end{array}$ & Dissertação: Educação \\
\hline $\begin{array}{l}\text { FLÔRES, Eneida } \\
\text { da Silva (2011) }\end{array}$ & $\begin{array}{c}\text { O uso da TV e do } \\
\text { computador nas } \\
\text { práticas docentes de } \\
\text { Língua Portuguesa na } \\
\text { educação de jovens e } \\
\text { adultos } \\
\end{array}$ & $\begin{array}{c}\text { Universidade } \\
\text { Federal de } \\
\text { Alagoas }\end{array}$ & Dissertação: Educação \\
\hline $\begin{array}{c}\text { FERNANDES, } \\
\text { Janira Rodrigues } \\
(\mathbf{2 0 1 2})\end{array}$ & $\begin{array}{c}\text { A integração das } \\
\text { tecnologias da } \\
\text { informação e } \\
\text { comunicação ao } \\
\text { currículo no PROEJA. }\end{array}$ & $\begin{array}{c}\text { Pontifícia } \\
\text { Universidade } \\
\text { Católica de São } \\
\text { Paulo }\end{array}$ & $\begin{array}{l}\text { Tese: Educação e } \\
\text { Currículo }\end{array}$ \\
\hline $\begin{array}{c}\text { AMPARO, } \\
\text { Matheus Augusto } \\
\text { Mendes; } \\
\text { SCHLÜNZEN } \\
\text { JUNIOR Klaus; } \\
\text { FURLANETT, } \\
\text { Maria Peregrina de } \\
\text { Fátima Rotta } \\
\text { (2013) }\end{array}$ & $\begin{array}{c}\text { Inclusão digital na } \\
\text { educação de jovens e } \\
\text { adultos: uma análise } \\
\text { em um município do } \\
\text { brasil }\end{array}$ & $\begin{array}{c}\text { Universidade } \\
\text { Estadual Paulista }\end{array}$ & Artigo \\
\hline $\begin{array}{l}\text { CORD, Deisi e } \\
\text { MELO, Sonia } \\
\text { Maria Martins } \\
\text { (2014) }\end{array}$ & $\begin{array}{c}\text { A produção de } \\
\text { conteúdo - vídeo - em } \\
\text { Tecnologia Digital de } \\
\text { Informação e } \\
\text { Comunicação (TDIC): } \\
\text { um recurso } \\
\text { pedagógico no } \\
\text { trabalho com uma } \\
\text { turma de alfabetização } \\
\text { da Educação de Jovens } \\
\text { e Adultos }\end{array}$ & $\begin{array}{l}\text { Universidade do } \\
\text { Estado de Santa } \\
\quad \text { Catarina }\end{array}$ & Artigo \\
\hline
\end{tabular}


Fonte: elaborado pelo pesquisador.

A dissertação de Goulart (2007), "Inclusão digital na terceira idade: a virtualidade como objeto e reencantamento da aprendizagem" objetiva compreender o que motiva pessoas da terceira idade a procurar por cursos de inclusão digital e constata que os idosos, mesmo com as perdas decorrentes do avanço de sua idade, possuem potencialidade para continuar aprendendo e que estar incluído na cultura digital é bastante significativo para os participantes da pesquisa. Os dados coletados em um curso de inclusão digital para a terceira idade em Porto Alegre, Rio Grande do Sul, apontam para a necessidade urgente de inserção deste grupo na cultura digital. Ainda que este trabalho não se relacione diretamente com a escolarização, é relevante para o debate, na medida em que serve para demonstrar a existência da demanda por inclusão de pessoas adultas no mundo digital, reconhecendo o ciberespaço como lugar de exercício da sociabilidade e cidadania.

"A educação de jovens e adultos no município de Curitiba sob a ótica de gênero e tecnologia", de Hidalgo (2007), procura caracterizar a EJA nas escolas municipais, sob a perspectiva dos estudantes frente às questões de gênero e tecnologia. Seu objetivo é identificar os motivos que levam homens e mulheres a retomar seu processo de escolarização e conhecer as relações de gênero presentes no espaço escolar. A temática da tecnologia perpassa transversalmente a pesquisa, pois aparece durante as entrevistas com os jovens e adultos como um fator decisivo em seu interesse em retornar à escola. Segundo a autora, este dado trouxe a necessidade de incluir em sua pesquisa o objetivo de conhecer as percepções que os alunos atribuem à tecnologia. Apesar de a questão tecnológica ser secundária neste trabalho, há relação com a presente pesquisa na medida em que Hidalgo (2007) compreende a EJA como um caminho para empoderar os sujeitos com a tecnologia da leitura e da escrita, o que possibilita sua inclusão na sociedade. Mais uma vez, é possível compreender uma aproximação com a noção de empoderamento freireano discutida mais profundamente em capítulo posterior.

A dissertação "O uso do computador, a alfabetização e a pós-alfabetização: o que dizem educandos/as do MOVA”, de Gonçalves (2007) objetiva analisar as contribuições da utilização do computador para a alfabetização e pós-alfabetização de jovens e adultos e para a superação da autoproteção por meio da fala dos educandos. O trabalho constata os benefícios do uso do computador na aquisição da leitura e da escrita na escolarização de jovens e adultos e aponta para a possiblidade de seu uso na emancipação dos sujeitos na Sociedade da Informação. Para indicar estes resultados, a autora se embasa no conceito de aprendizagem 
dialógica de Paulo Freire e tece seus argumentos, no sentido de valorizar as contribuições do uso da tecnologia nos processos de escolarização para o que chama de emancipação digital. Esta ideia coaduna-se com o conceito de empoderamento freireano, na medida em que emancipação digital é compreendida como a conquista da autonomia, a partir de uma perspectiva crítica, o que ultrapassa o conceito de inclusão digital, ligado apenas à perspectiva de domínio instrumental das tecnologias.

Gontijo e Oliveira (2008) apresentaram o artigo "Vozes docentes e discentes sobre condições, objetivos e contribuições do uso das TIC na EJA" no I Seminário Nacional de Educação Profissional e Tecnológica do Centro Federal de Educação Tecnológica, em Belo Horizonte, Minas Gerais, que analisa a utilização das tecnologias em termos de condições de uso, objetivos e contribuições que têm para alunos e professores da EJA, por meio do mapeamento da presença da temática na produção da área e uma revisão teórica da produção acadêmica que aborda as TDIC nos processos sócio-educacionais em curso. As autoras identificam na revisão de literatura que há poucos estudos na área, em âmbito nacional e internacional, que focalizam a utilização das TDIC na EJA. Problematizam o delineamento de uma possível dupla marginalização na área: marginalização dessa modalidade de ensino das políticas que visam à introdução das TDIC nas escolas e marginalização das TDIC nas políticas voltadas para a EJA no país.

Santos (2008), ao investigar como pensa, interage e faz uso das TDIC o imenso contingente de população não alfabetizada da Bahia, faz uma análise bastante perspicaz das narrativas da história de vida de trabalhadores da construção civil não escolarizados ou de baixa escolaridade que estão presentes em cursos de alfabetização e letramento oferecidos nos canteiros de obras. Sua dissertação "Tá vendo aquele edifício, moço? - A especificidade da inclusão digital para trabalhadores da construção civil não alfabetizados" tem como objetivo identificar como se encontra o trabalhador que não foi alfabetizado na leitura e escrita em língua portuguesa e que agora demanda por letramento digital para o pleno exercício de sua cidadania. Assim como é proposto no presente trabalho, Santos (2008) associa a inclusão digital ao processo de conquista da autonomia e exercício pleno da cidadania e alerta para o perigo das tecnologias serem utilizadas como argumento para uma possível exclusão ou incapacidade atribuída aos jovens e adultos não alfabetizados para lidar com os recursos da informação e da comunicação. Os resultados da pesquisa revelam que as salas de aula implantadas nos canteiros de obras seguem uma proposta didática centrada no analógico e não alcançam a efetividade digital demandada pelos trabalhadores-alunos. 
Entre os artigos, dissertações e teses coletados, o trabalho de Cruz (2008) merece destaque, pelo fato de apresentar em sua conclusão a constatação da necessidade de se ampliar o tempo e o espaço para a formação de professores para o uso das TDIC. A dissertação “Limites e possibilidades das tecnologias na educação de jovens e adultos" identifica as possíveis contribuições do uso das tecnologias na educação de jovens e adultos no processo de ensino e aprendizagem de uma escola que possui boas condições materiais para sua implementação. A autora parte do pressuposto de que as tecnologias são variáveis das relações de poder na sociedade contemporânea e, diante disso, ter seu domínio é uma questão de fortalecimento do sujeito frente à dinâmica social. A partir da observação participante, análise documental, questionários e entrevistas realizadas com professores e alunos, Cruz (2008) constata que a utilização das TDIC é ainda incipiente, mesmo em uma escola bem equipada. Percebe também que a ausência de tempo e espaço para o aprimoramento docente é um limite imponente ao uso das tecnologias em salas de aula da EJA, mas que a formação adequada permite que os docentes avancem em suas práticas pedagógicas, resgatando a infraestrutura tecnológica de maneira criativa e significativa. Sua conclusão é uma relevante justificativa para a presente pesquisa, na medida em que o descompromisso com a formação de professores para o uso das TDIC é um empecilho para o avanço neste campo, mesmo em escolas com acesso a elas.

As conclusões da pesquisa de Nápoles (2008) também apontam para o despreparo dos professores quanto ao uso pedagógico das TDIC, em sua dissertação "O uso das tecnologias da informação e comunicação na educação de jovens e adultos: visão de alunos e professores de uma escola municipal de Belo Horizonte". O estudo de caso, cujo objetivo é investigar a percepção que discentes e docentes de uma escola municipal de ensino médio na modalidade EJA possuem sobre as TDIC, observou a utilização do laboratório de informática da escola e entrevistou alunos e professores. A autora percebeu o subaproveitamento do espaço, especialmente pelos professores, que, segundo ela, não estão adequadamente capacitados para o uso das tecnologias de uma forma inovadora, pois apenas reproduzem suas práticas de sala de aula com o uso da ferramenta. Quanto à percepção que discentes e docentes fazem das TDIC, o estudo aponta que elas são consideradas essenciais para o desenvolvimento das aptidões necessárias à autonomia do cidadão. Em diálogo com o presente, pode-se afirmar que, mais uma vez, o conceito de empoderamento freireano está subscrito e que a formação adequada de professores para o uso pedagógico das TDIC é consensualmente mais que urgente. 
Na mesma direção e sob a mesma perspectiva de Cruz (2008) e Nápoles (2008), a dissertação "Tecnologias de informação e de comunicação na educação de jovens e adultos" de Gontijo (2008), objetiva contribuir para a compreensão do uso das TDIC na educação de pessoas jovens e adultas. A pesquisa procura identificar a natureza da formação de professores para o uso das tecnologias na EJA, além das condições em que professores usam ou deixam de usá-las em suas práticas pedagógicas. A partir de uma pesquisa teórica e empírica, baseada nas entrevistas de discentes, docentes e coordenação do laboratório de informática de uma escola municipal de Belo Horizonte, Minas Gerais, a autora sugere que professores e alunos consideram as TDIC uma inovação no contexto da EJA, mas se apropriam delas de formas diferentes. Conclui que o uso das TDIC contribui para o aumento da autoestima dos alunos e para a redução das suas taxas de flutuação. Além disso, a pesquisadora identificou uma perspectiva fortemente instrumental na formação dos professores para o uso das TDIC, na medida em que o uso das tecnologias na escola projeta-se para o nível da alfabetização digital, isto é, o domínio incipiente e mecânico das tecnologias, distante da perspectiva crítica, fundamental para o processo de empoderamento e conquista da autonomia. Em seus apontamentos finais, Gontijo (2008) também indica a necessidade urgente de pesquisas no campo da formação de professores e gestores para a incorporação das TDIC nas práticas escolares.

Brito (2010), em sua dissertação "Jovens e Adultos em processo de escolarização e as tecnologias digitais: quem usa, a favor de quem e para quê?", realiza entrevistas com alunos da modalidade EJA, em escolas públicas de São Paulo, com o objetivo de investigar a presença das tecnologias na EJA, por meio dos usos que estudantes dizem fazer desses recursos e as possíveis relações desses usos com o processo de escolarização e as aprendizagens que vivenciam. A maior parte dos alunos, segundo o trabalho, faz uso das TDIC fora das escolas para se divertir, se comunicar e aprender sobre temas de seu interesse. A autora aponta para o fato de que quanto mais escolarizados, mais os sujeitos se apropriam das tecnologias, na medida em que o seu uso depende muitas vezes de saberes prévios aprendidos na escola. $\mathrm{O}$ foco central deste trabalho está no sentido que os alunos dão às tecnologias e ao uso que dizem fazer do computador. Em sua conclusão, a autora destaca as variadas percepções que estes alunos têm sobre o uso das tecnologias e, em convergência com esta pesquisa, considera a inserção destes sujeitos na cultura digital um caminho necessário para o exercício pleno da cidadania. 
A dissertação de mestrado de Coelho (2011), intitulada "As relações dos alunos da EJA com as tecnologias digitais: implicações e possibilidades na vida de cada um" investiga uma escola na cidade de Salvador, Bahia, que faz uso das tecnologias em todas as fases de escolarização, a partir da perspectiva de que não é mais possível alfabetizar ou escolarizar ignorando as dinâmicas, concepções e tecnologias que norteiam os processos sociais contemporâneos. Seu objetivo é investigar e analisar como se dão as relações dos alunos da EJA com as tecnologias digitais e de quais formas eles ressignificam seus saberes e compreensão de mundo a partir dessas relações. Com base nos dados obtidos através de entrevistas e observações do uso do laboratório de informática da escola, Coelho (2011) conclui que o uso das tecnologias altera a visão de mundo dos alunos da EJA e o seu cotidiano, em casa e no trabalho. As TDIC na educação contribuem significativamente também para elevar a autoestima deles, para adquirirem confiança de que também são capazes de se apropriar dessas tecnologias e passar a usá-las de forma autônoma, isto é, as TDIC na educação situam-se como um instrumento de empoderamento e inclusão de jovens e adultos no exercício pleno da cidadania.

O trabalho de Flôres (2011) investiga as práticas de professores da EJA que norteiam o ensino e aprendizagem da leitura e da escrita por meio do uso da TV e do computador como ferramentas sociais e de aprendizagem. O estudo de caso, intitulado "O uso da TV e do computador nas práticas docentes de Língua Portuguesa na educação de jovens e adultos" observou e entrevistou alunos e professores de ensino fundamental na modalidade EJA em uma escola municipal e outra estadual de Maceió, Alagoas. Assim como outros autores, Flôres (2011) também adverte para o uso ainda muito incipiente dessas tecnológicas na disciplina de Língua Portuguesa na EJA das escolas investigadas e reconhece que os professores necessitam de maior capacitação para conhecer e saber utilizar as múltiplas estratégias que a TV e o computador podem oferecer para o processo de ensinoaprendizagem, ainda que reconheçam a importância das tecnologias na integração das pessoas no meio social e no trabalho, para a educação e dinamização das suas estratégias pedagógicas. Se utilizadas adequadamente pelos profissionais da educação, as tecnologias conseguem, de acordo com a pesquisa, servir de suporte para as aulas e contribuir para o processo educativo. A formação de professores aparece mais uma vez como elemento chave para compreensão do tema.

A tese "A integração das tecnologias da informação e comunicação ao currículo no PROEJA”, de Fernandes (2012), procura identificar caminhos para a utilização do potencial 
estratégico das TDIC, tendo em vista a construção do currículo integrado no âmbito do PROEJA - Programa Nacional de Integração da Educação Profissional com a Educação Básica na modalidade da Educação de Jovens e Adultos. A autora procura investigar os documentos base do PROEJA e o plano de curso do PROEJA do Instituto Federal de Educação, Ciência e Tecnologia de São Paulo, com o objetivo de compreender os significados dados à potencialidade das TDIC na integração da educação profissional à educação de jovens e adultos no ensino médio. Além disso, a pesquisadora também procura estabelecer contato com seu corpus de investigação por meio da aproximação junto aos professores do curso tomado como objeto de análise. Seu objetivo foi de criar um contexto crítico colaborativo junto ao professor de informática e demais docentes para compreender os significados que atribuem ao potencial das TDIC e compartilhar novos significados da integração das TDIC no currículo do programa. Neste trabalho, há mais centralidade na relação entre o currículo e as TDIC e no sentido que os professores dão às tecnologias no currículo do programa investigado. De modo geral, a autora conclui que parte dos professores compreendem as TDIC a partir de uma perspectiva instrumental, o que impacta significativamente na constituição do currículo, e também exclama para a necessidade de se repensar a formação de professores para o uso pedagógico das TDIC.

Nos anais do VI Seminário Luso-Brasileiro - Educação, Trabalho e Movimentos Sociais, realizado em Lisboa, Portugal, Amparo et al. (2013) publicaram o trabalho "Inclusão digital na educação de jovens e adultos: uma análise em um município do Brasil" cujo objetivo é apresentar os resultados de uma pesquisa exploratória, realizada no ano de 2012 que teve como intuito a identificação da existência de um trabalho que possa contribuir para a inclusão digital em salas de educação de jovens e adultos em um município do Brasil. Foram observadas quatro escolas por um período de quatro meses, além da realização de entrevistas com professores e estudantes. Os resultados finais, segundo os autores, apontam para uma situação preocupante: os professores das escolas investigadas não têm incitado qualquer processo de inclusão digital em suas aulas ou, quando há presença de tecnologias, ela se dá de forma mecanizada. A preocupação dos pesquisadores é com a reprodução do processo de exclusão digital. Apesar de não deixar isto claro no texto, os autores estão alertando também para a má formação para o uso das TDIC dos educadores que atuam nas escolas investigadas, na medida em que elas tinham amplas condições estruturais de promover o acesso destes sujeitos à cultura digital. 
Em trabalho apresentado no Congresso Ibero-Americano de Ciência, Tecnologia, Inovação e Educação, realizado em Buenos Aires, Argentina, Cord e Melo (2014) apresentam a experiência com a produção de conteúdo digital (vídeo) em uma turma de alfabetização na Educação de Jovens e Adultos (EJA) do município de Florianópolis, Santa Catarina. Em “A produção de conteúdo - vídeo - em Tecnologia Digital de Informação e Comunicação (TDIC): um recurso pedagógico no trabalho com uma turma de alfabetização da Educação de Jovens e Adultos", as autoras descrevem o trabalho pedagógico de produção de vídeo, cujo objetivo era convidar outras pessoas a retomar sua escolarização por meio da EJA, por estudantes da turma de alfabetização. O trabalho resultou em um processo pedagógico de construção de saberes e afirmação de identidades, com vistas ao exercício da cidadania. Segundo as pesquisadoras, o projeto também ratificou as potencialidades das TDIC, ao permitir a sujeitos em processo de alfabetização se (re)conhecerem como autores, criadores de um conteúdo inédito e tão importante para outras pessoas. A produção de conteúdo digital na EJA teria, segundo Cord e Melo (2014), a dupla função de ampliar as possibilidades de circulação dos próprios estudantes em um mundo letrado e altamente tecnologizado e também ampliar sua participação cidadã em uma sociedade cada vez mais crivada de processos de informação e comunicação. Concluem que é possível que sujeitos, como os estudantes em questão, pouco escolarizados e com pouquíssima experiência no uso das TDIC, possam assenhorar-se de todo o processo de produção e comunicação existente na produção de um vídeo e assim possibilitar a conquista de espaço para exercitar a cidadania.

Diante deste quadro de artigos, dissertações e teses publicadas entre 2007 e 2014, que relacionam as TDIC com a educação de jovens e adultos, é possível observar algumas tendências deste campo de pesquisa. A primeira delas refere-se à escassez de trabalhos preocupados em investigar o impacto das tecnologias na EJA. Trabalhos como os de Coelho (2011), Hidalgo (2007), Nápoles (2008), Santos (2008) e Fernandes (2012), por exemplo, fazem críticas à secundarização, tanto do campo de pesquisa em EJA, quanto aos estudos acadêmicos sobre uso pedagógico das TDIC. Gontijo e Melo (2007) vão além, pois observam a marginalização da EJA das políticas e estudos que visam à inserção das TDIC nas escolas e marginalização das TDIC nas políticas e estudos voltados para a EJA no país. Estes dados são representativos de que não há ainda grande mobilização de pesquisadores do campo das tecnologias educacionais, para refletir sobre sua temática no contexto específico da educação de adultos. Da mesma forma, a revisão de literatura apresenta indícios de que também não é prioridade dos pesquisadores do campo da educação de jovens e adultos a investigação sobre 
os limites e as possibilidades do uso pedagógico das TDIC e da inclusão digital nesta modalidade escolar.

A segunda tendência refere-se à percepção dos autores em relação à potencialidade do uso das TDIC na EJA como contribuição ao processo de ensino-aprendizagem e como parte fundamental do processo de inclusão digital, que se apresenta como chave para a reflexão sobre o acesso da população economicamente desfavorecida à vivência plena da cibercultura. Todos os autores partem da suposição de que ações que insiram pessoas jovens e adultas que retomam seu processo de escolarização na cultura digital podem significar ganhos em sua aprendizagem e contribuir para sua emancipação enquanto sujeitos e enquanto classe, ou seja, para seu empoderamento.

A terceira percepção que se tem da análise da revisão destas pesquisas advém de seus resultados finais. Autores como Hidalgo (2007), Santos (2008), Cruz (2008), Nápoles (2008), Gontijo (2008), Flores (2011) e Fernandes (2012) criticam a perspectiva instrumental do uso das TDIC por professores da EJA observada em situações investigadas em suas pesquisas e apontam insistentemente para a necessidade de se repensar a formação docente. Mais que uma tendência apontada por estas pesquisas, a formação de professores para uso pedagógico das TDIC é uma demanda urgente e é investigada por autores que, apesar de não terem como corpus de pesquisa o contexto da educação de jovens e adultos, também dialogam com o presente trabalho.

\subsection{Pesquisas sobre a formação de professores para o uso pedagógico das TDIC}

Em um segundo cruzamento de palavras-chave, buscaram-se teses, dissertações e artigos acadêmicos que tratassem da formação de professores para o uso das TDIC, independentemente da modalidade de ensino, desconsiderando, desta vez, a busca por trabalhos necessariamente inseridos no contexto da EJA. Foram selecionados os trabalhos que melhor dialogam com o presente estudo. O quadro abaixo apresenta 25 pesquisas acerca do subtema:

Quadro 2 - Pesquisas sobre a formação de professores para o uso pedagógico das TDIC

\begin{tabular}{|c|c|c|c|}
\hline Autor/Ano & Título & Instituição & $\begin{array}{c}\text { Publicação } \\
\text { (Dissertação/Tese/Artigo) }\end{array}$ \\
\hline $\begin{array}{c}\text { BARROS, Daniela } \\
\text { Malaré Vieira } \\
\text { (2007) }\end{array}$ & $\begin{array}{c}\text { Formação continuada } \\
\text { para docentes do } \\
\text { ensino superior: o } \\
\text { virtual como espaço } \\
\text { educativo }\end{array}$ & $\begin{array}{c}\text { Universidade } \\
\text { Estadual Paulista }\end{array}$ & Artigo \\
\hline ALONSO, Katia & Tecnologias da & Universidade & Artigo \\
\hline
\end{tabular}




\begin{tabular}{|c|c|c|c|}
\hline Morosov (2008) & $\begin{array}{c}\text { informação e } \\
\text { comunicação e } \\
\text { formação de } \\
\text { professores: sobre rede } \\
\text { e escolas } \\
\end{array}$ & $\begin{array}{c}\text { Federal do Mato } \\
\text { Grosso }\end{array}$ & \\
\hline $\begin{array}{l}\text { CANTINI, Marcos } \\
\text { Cezar (2008) }\end{array}$ & $\begin{array}{l}\text { Políticas públicas e } \\
\text { formação de } \\
\text { professores na área de } \\
\text { tecnologias da } \\
\text { informação e } \\
\text { comunicação - TIC na } \\
\text { rede pública estadual } \\
\text { do Paraná } \\
\end{array}$ & $\begin{array}{c}\text { Pontifícia } \\
\text { Universidade } \\
\text { Católica do } \\
\text { Paraná }\end{array}$ & Dissertação: Educação \\
\hline $\begin{array}{l}\text { TOZETTO, Jozeli } \\
\text { Monteiro (2008) }\end{array}$ & $\begin{array}{l}\text { Formação docente, } \\
\text { prática pedagógica, } \\
\text { tecnologias da } \\
\text { informação e } \\
\text { comunicação: rupturas } \\
\text { e transformações em } \\
\text { uma instituição de } \\
\text { ensino superior }\end{array}$ & $\begin{array}{c}\text { Pontifícia } \\
\text { Universidade } \\
\text { Católica do } \\
\text { Paraná }\end{array}$ & Dissertação: Educação \\
\hline $\begin{array}{l}\text { SANTOS, Ezicléia } \\
\text { Tavares (2009) }\end{array}$ & $\begin{array}{l}\text { A formação dos } \\
\text { professores para o uso } \\
\text { das tecnologias } \\
\text { digitais nos GTs } \\
\text { formação de } \\
\text { professores e educação } \\
\text { e comunicação da } \\
\text { ANPEDd - 2000 a } \\
2008 \\
\end{array}$ & $\begin{array}{c}\text { Universidade } \\
\text { Federal de Juiz de } \\
\text { Fora }\end{array}$ & Artigo \\
\hline $\begin{array}{c}\text { LOPES, Rosemara } \\
\text { Perpétua; } \\
\text { FÜRKOTTER, } \\
\text { Monica (2010) }\end{array}$ & $\begin{array}{l}\text { Formação para o uso } \\
\text { das tecnologias } \\
\text { digitais de informação } \\
\text { e comunicação (TDIC) } \\
\text { nas licenciaturas } \\
\text { presenciais das } \\
\text { universidades } \\
\text { estaduais paulistas }\end{array}$ & $\begin{array}{c}\text { Universidade } \\
\text { Estadual Paulista }\end{array}$ & Artigo \\
\hline $\begin{array}{l}\text { SILVA, Cleder } \\
\text { Tadeu Antão da; } \\
\text { GARÍGLIO, José } \\
\text { Ângelo (2010) }\end{array}$ & $\begin{array}{c}\text { A formação } \\
\text { continuada de } \\
\text { professores para o uso } \\
\text { das Tecnologias da } \\
\text { Informação e } \\
\text { Comunicação (TIC): o } \\
\text { caso do projeto } \\
\text { Escolas em Rede, da } \\
\text { Rede Estadual de } \\
\text { Educação de Minas } \\
\text { Gerais } \\
\end{array}$ & $\begin{array}{c}\text { Universidade do } \\
\text { Estado de Minas } \\
\text { Gerais e } \\
\text { Universidade } \\
\text { Federal de Minas } \\
\text { Gerais }\end{array}$ & Artigo \\
\hline $\begin{array}{c}\text { BARCELOS, } \\
\text { Gilmara Teixeira } \\
(2011)\end{array}$ & $\begin{array}{c}\text { Tecnologias na prática } \\
\text { docente de professores } \\
\text { de matemática: } \\
\text { formação continuada } \\
\text { com apoio de uma } \\
\end{array}$ & $\begin{array}{l}\text { Universidade } \\
\text { Federal do Rio } \\
\text { Grande do Sul }\end{array}$ & $\begin{array}{l}\text { Tese: Informática } \\
\text { Educativa }\end{array}$ \\
\hline
\end{tabular}




\begin{tabular}{|c|c|c|c|}
\hline & rede social na internet & & \\
\hline $\begin{array}{l}\text { KLAMMER, Celso } \\
\text { Rogério (2011) }\end{array}$ & $\begin{array}{l}\text { Formação continuada } \\
\text { para a prática docente } \\
\text { no paradigma da } \\
\text { complexidade com uso } \\
\text { das tecnologias da } \\
\text { informação e } \\
\text { comunicação }\end{array}$ & $\begin{array}{c}\text { Pontifícia } \\
\text { Universidade } \\
\text { Católica do } \\
\text { Paraná }\end{array}$ & Tese: Educação \\
\hline $\begin{array}{l}\text { LARA, Rafael da } \\
\text { Cunha (2011) }\end{array}$ & $\begin{array}{l}\text { Impressões digitais } \\
\text { entre professores e } \\
\text { estudantes: um estudo } \\
\text { sobre o uso das TIC na } \\
\text { formação inicial de } \\
\text { professores nas } \\
\text { universidades públicas } \\
\text { de Santa Catarina }\end{array}$ & $\begin{array}{l}\text { Universidade do } \\
\text { Estado de Santa } \\
\text { Catarina }\end{array}$ & Dissertação: Educação \\
\hline $\begin{array}{l}\text { MACHADO, } \\
\text { Lisandro Lemos } \\
\text { (2011) }\end{array}$ & $\begin{array}{l}\text { Informática educativa: } \\
\text { elementos para uma } \\
\text { proposta de formação } \\
\text { continuada de } \\
\text { professores }\end{array}$ & $\begin{array}{l}\text { Universidade de } \\
\text { Passo Fundo }\end{array}$ & Dissertação: Educação \\
\hline $\begin{array}{l}\text { MAIA, Hélio José } \\
\text { dos Santos (2011) }\end{array}$ & $\begin{array}{c}\text { Formação para o } \\
\text { ensino de ciências e o } \\
\text { uso de tecnologias da } \\
\text { informação e } \\
\text { comunicação, um } \\
\text { estudo de caso } \\
\end{array}$ & $\begin{array}{c}\text { Universidade de } \\
\text { Brasília }\end{array}$ & $\begin{array}{l}\text { Dissertação: Ensino de } \\
\text { Ciências }\end{array}$ \\
\hline $\begin{array}{c}\text { PLACIDO, Maria } \\
\text { Elze dos Santos } \\
(2011)\end{array}$ & $\begin{array}{l}\text { Formação continuada } \\
\text { de professores: análise } \\
\text { sobre o uso das } \\
\text { tecnologias da } \\
\text { informação e } \\
\text { comunicação - TIC na } \\
\text { organização do } \\
\text { trabalho pedagógico }\end{array}$ & $\begin{array}{l}\text { Universidade } \\
\text { Federal de } \\
\text { Sergipe }\end{array}$ & Dissertação: Educação \\
\hline $\begin{array}{c}\text { PROCÓPIO, } \\
\text { Elizabete Ramalho } \\
\text { (2011) }\end{array}$ & $\begin{array}{c}\text { Formação de } \\
\text { professores e } \\
\text { tecnologias: } \\
\text { implicações da } \\
\text { educação a distância } \\
\text { na prática docente } \\
\end{array}$ & $\begin{array}{c}\text { Universidade } \\
\text { Federal de Juiz de } \\
\text { Fora }\end{array}$ & Dissertação: Educação \\
\hline $\begin{array}{c}\text { SALESI, Luciana } \\
\text { (2011) }\end{array}$ & $\begin{array}{l}\text { A influência do uso } \\
\text { das tecnologias da } \\
\text { informação e } \\
\text { comunicação (TIC) na } \\
\text { formação de } \\
\text { professores }\end{array}$ & $\begin{array}{c}\text { Universidade do } \\
\text { Oeste Paulista }\end{array}$ & Dissertação: Educação \\
\hline $\begin{array}{c}\text { SANTOS, Flavia } \\
\text { Freitas Fontany dos } \\
(\mathbf{2 0 1 1})\end{array}$ & $\begin{array}{c}\text { Informática e } \\
\text { educação: formação de } \\
\text { professores e políticas } \\
\text { públicas }\end{array}$ & $\begin{array}{c}\text { Universidade } \\
\text { Federal do Estado } \\
\text { do Rio de Janeiro }\end{array}$ & Dissertação: Educação \\
\hline $\begin{array}{c}\text { SCHRAINER, } \\
\text { Juliana Cristina } \\
\text { (2011) }\end{array}$ & $\begin{array}{c}\text { Formação de } \\
\text { professores e as } \\
\text { possibilidades de }\end{array}$ & $\begin{array}{c}\text { Pontifícia } \\
\text { Universidade } \\
\text { Católica do }\end{array}$ & Dissertação: Educação \\
\hline
\end{tabular}




\begin{tabular}{|c|c|c|c|}
\hline & $\begin{array}{c}\text { utilização das } \\
\text { tecnologias da } \\
\text { informação e } \\
\text { comunicação na } \\
\text { aprendizagem } \\
\end{array}$ & Paraná & \\
\hline $\begin{array}{l}\text { SILVA, Leandro } \\
\text { Ferreira (2011) }\end{array}$ & $\begin{array}{l}\text { As tecnologias da } \\
\text { informação e } \\
\text { comunicação na } \\
\text { formação inicial de } \\
\text { professores de } \\
\text { matemática em Recife } \\
\text { e região metropolitana }\end{array}$ & $\begin{array}{c}\text { Universidade } \\
\text { Federal Rural de } \\
\text { Pernambuco }\end{array}$ & $\begin{array}{l}\text { Dissertação: Ensino das } \\
\text { Ciências e Matemática }\end{array}$ \\
\hline $\begin{array}{c}\text { TURIANI, José } \\
\text { Luis de Melo (2011) }\end{array}$ & $\begin{array}{c}\text { Formação continuada } \\
\text { de professores e TIC: } \\
\text { contribuições do Curso } \\
\text { Mídias na Educação }\end{array}$ & $\begin{array}{c}\text { Universidade } \\
\text { Presbiteriana } \\
\text { Mackenzie }\end{array}$ & $\begin{array}{l}\text { Dissertação: Educação, } \\
\text { Arte e História da Cultura }\end{array}$ \\
\hline $\begin{array}{l}\text { ZUFFO, Darci } \\
\text { (2011) }\end{array}$ & $\begin{array}{c}\text { A formação de } \\
\text { professores para o uso } \\
\text { das tecnologias } \\
\text { educacionais: o que } \\
\text { apontam as teses e } \\
\text { dissertações } \\
\text { defendidas no Brasil } \\
\text { entre } 2003 \text { e } 2008 .\end{array}$ & $\begin{array}{c}\text { Pontifícia } \\
\text { Universidade } \\
\text { Católica do } \\
\text { Paraná }\end{array}$ & Dissertação: Educação \\
\hline $\begin{array}{l}\text { CARVALHO, } \\
\text { Maurílio (2012) }\end{array}$ & $\begin{array}{c}\text { Tecnologia da } \\
\text { informação e da } \\
\text { comunicação (TIC) e } \\
\text { ensino-aprendizagem } \\
\text { de língua portuguesa: } \\
\text { implicações na } \\
\text { formação do professor }\end{array}$ & $\begin{array}{c}\text { Universidade de } \\
\text { Taubaté }\end{array}$ & $\begin{array}{c}\text { Dissertação: Linguística } \\
\text { Aplicada }\end{array}$ \\
\hline $\begin{array}{c}\text { FROZI, Valtrícia } \\
\text { Lucelita (2012) }\end{array}$ & $\begin{array}{l}\text { De contextos do fazer } \\
\text { pedagógico: entre } \\
\text { formação continuada e } \\
\text { tecnologias da } \\
\text { informação e } \\
\text { comunicação }\end{array}$ & $\begin{array}{c}\text { Universidade } \\
\text { Federal do Mato } \\
\text { Grosso }\end{array}$ & Dissertação: Educação \\
\hline $\begin{array}{c}\text { IGLESIAS, Sandra } \\
\text { Letícia Schroeder } \\
(\mathbf{2 0 1 2})\end{array}$ & $\begin{array}{c}\text { A formação do } \\
\text { pedagogo e as } \\
\text { tecnologias } \\
\text { educacionais: } \\
\text { realidade ou ficção? }\end{array}$ & $\begin{array}{c}\text { Pontifícia } \\
\text { Universidade } \\
\text { Católica do } \\
\text { Paraná }\end{array}$ & Dissertação: Educação \\
\hline $\begin{array}{c}\text { MILHOMEM, } \\
\text { André Luiz Borges } \\
(\mathbf{2 0 1 2})\end{array}$ & $\begin{array}{l}\text { A formação inicial de } \\
\text { professores nos cursos } \\
\text { de licenciatura do } \\
\text { campus universitário } \\
\text { Jane Vanini - } \\
\text { UNEMAT/Cáceres- } \\
\text { MT em relação ao uso } \\
\text { do computador na } \\
\text { educação básica. } \\
\end{array}$ & $\begin{array}{l}\text { Universidade do } \\
\text { Estado de Mato } \\
\text { Grosso }\end{array}$ & Dissertação: Educação \\
\hline $\begin{array}{l}\text { SILVA, Analígia } \\
\text { Miranda da (2013) }\end{array}$ & $\begin{array}{c}\text { O computador na } \\
\text { educação e a formação } \\
\text { docente: perspectivas }\end{array}$ & $\begin{array}{c}\text { Universidade } \\
\text { Estadual Paulista }\end{array}$ & Artigo \\
\hline
\end{tabular}




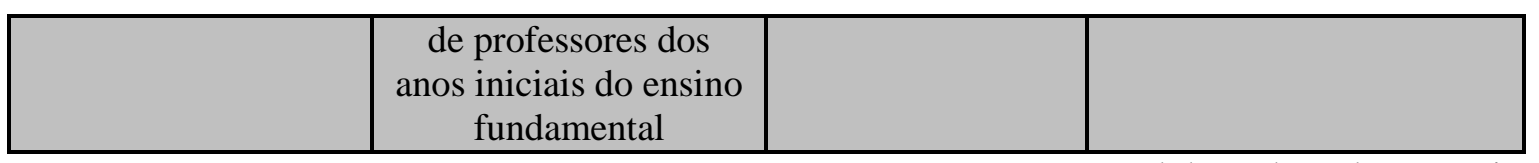

Fonte: elaborado pelo pesquisador.

Barros (2007), em artigo intitulado "Formação continuada para docentes do ensino superior: o virtual como espaço educativo" relata sua experiência na estruturação e aplicação de um curso de formação continuada, experienciado em uma instituição privada de formação de professores entre 2004 e 2005. A autora considera que a formação continuada é, atualmente, um processo emergente de atualização e mudança dos conhecimentos novos e informações relevantes e que, em conexão com o espaço da virtualidade a formação continuada, se desenvolve e promove o acesso para a formação do cidadão, que não pode estar distante da tecnologia, de seus elementos e características que mudam estilos, necessidades e, até mesmo, as exigências profissionais dos mercados mundiais. Seu estudo relaciona-se com a presente pesquisa, especialmente, devido à preocupação com a formação continuada como estratégia de contato do professor com a cibercultura.

No artigo "Tecnologias da informação e comunicação e formação de professores: sobre rede e escola", Alonso (2008) tece importantes reflexões sobre a natureza do trabalho pedagógico diante da temática das TDIC aliada à formação de professores. Ela afirma que o uso de recursos tecnológicos sofisticados não tem assegurado transformações nas práticas pedagógicas nas escolas e, objetivando investigar esta negativa, a autora considera que a lógica estabelecida pelas TDIC implica trabalho em rede, muito diferente da lógica real das escolas atualmente. A autora também refuta a visão, muitas vezes expressas em algumas pesquisas que compreendem as TDIC como uma verdadeira panaceia educativa, o que produz a necessidade de se repensar a formação inicial e continuada de professores.

A dissertação produzida por Tozetto (2008) traz considerações importantes sobre a necessidade de formação do professor, enquanto sujeito crítico, criativo e reflexivo, no contexto de uma contemporaneidade imersa na cibercultura. O estudo "Formação docente, prática pedagógica, tecnologias da informação e comunicação: rupturas e transformações em uma instituição de ensino superior" analisa, por meio de entrevistas com 16 professores de uma mesma instituição, as características e práticas do professor do ensino superior no que se refere ao uso das TDIC. Seus dados apontam para o uso restrito das TDIC nas práticas destes professores, que permanecem fazendo uso de ferramentas tradicionais em suas aulas, ou uso de recursos tecnológicos como instrumentos de reprodução de práticas tradicionais. De acordo com a autora, para que efetivamente o professor do ensino superior compreenda e faça uso do 
computador e de outras mídias digitais é preciso que ele reconheça suas possibilidades inovadoras e que supere a visão reproducionista do papel do professor em direção a um papel de mediador, dinâmico e parceiro do aluno na construção do conhecimento. Em conclusão, a autora sugere maior preocupação das Instituições de Ensino Superior na formação continuada de seu corpo docente para o uso das TDIC na formação de seus alunos.

O estudo de caso desenvolvido por Catini (2008) investiga as formas como ocorre o processo de formação continuada de professores da rede pública estadual do Paraná, no campo do uso pedagógico das TDIC, a partir da efetivação de políticas públicas estaduais e federais, como o Programa Nacional de Informática na Educação (PROINFO ${ }^{7}$ ) e o Programa de Extensão, Melhoria e Inovação do Ensino Médio do Paraná (PROEM). Em análise documental e entrevistas com os gestores responsáveis pela implementação dos programas estaduais na área de tecnologia na educação, o pesquisador detecta uma série de obstáculos ao uso das TDIC no processo pedagógico - apesar das ações dos programas citados - e reconhece sua relevância como elemento capaz de fomentar a produção de conhecimento de forma crítica e reflexiva. Há claras discordâncias entre as propostas dos programas e suas condições reais de implementação, como problemas de infraestrutura, manutenção e a própria formação pedagógica continuada dos professores da rede. Neste campo, as dificuldades no processo de progressão das carreiras dos professores que efetivem o uso das TDIC em suas práticas, a sua disponibilidade em participar da formação fora de sua jornada de trabalho, entre outros entraves, emperram a efetivação destes programas.

O artigo de Santos (2009) faz uma análise dos trabalhos publicados nos Grupos de Trabalho (GT 08 - Formação de Professores e GT 16 - Educação e Comunicação) da ANPEd, que abordam a formação dos professores para o uso das tecnologias digitais entre os anos de 2000 e 2008. O recorte temporal se justifica pela ênfase que a temática adquire a partir dos anos 2000 e seu objetivo é refletir como a questão da formação dos professores para uso das tecnologias digitais está sendo contemplada nas reuniões anuais da ANPEd. Os resultados dos trabalhos apontam caminhos para o repensar das propostas de formação dos professores na área das TDIC, ao destacarem que as práticas inovadoras surgem da reflexão sobre experiências compartilhadas, a necessidade de formação crítica reflexiva para uso das

\footnotetext{
${ }^{7}$ O Programa Nacional de Tecnologia Educacional (ProInfo) é um programa educacional com o objetivo de promover o uso pedagógico da informática na rede pública de educação básica. O programa leva às escolas computadores, recursos digitais e conteúdos educacionais. Em contrapartida, estados, Distrito Federal e municípios devem garantir a estrutura adequada para receber os laboratórios e capacitar os educadores para uso das máquinas e tecnologias.
} 
tecnologias. Sobre a formação, as pesquisas analisadas por Santos (2009) evidenciam problemas advindos de uma formação inicial distante do uso de recursos tecnológicos, uma formação continuada descontextualizada, aligeirada e centrada nas questões técnicas do computador/internet.

Em "Formação para o uso das tecnologias digitais de informação e comunicação (TIDIC) nas licenciaturas presenciais das universidades estaduais paulistas", artigo publicado na $33^{\text {a }}$ Reunião Anual da ANPEd, em 2010, Lopes e Fürkotter (2010) focalizam as TDIC na formação docente, com o objetivo de investigar se a formação do professor que atuará na Educação Básica contempla conhecimentos sobre TDIC e sob qual paradigma pedagógico os mesmos se articulam. Em busca por respostas, a pesquisa documental fez a análise de cinco cursos de licenciatura da área de exatas de três universidades estaduais paulistas, por meio de sua grade curricular e seu projeto pedagógico. A análise das licenciaturas permitiu constatar que nenhum dos projetos pedagógicos inclui em seus objetivos a formação do futuro professor da Educação Básica para o uso das TDIC. Além de alguns dos cursos pesquisados não incluírem capacidades relativas ao uso das TDIC em contextos educacionais no perfil do egresso. Os resultados apresentados neste trabalho levam as autoras a insistir no fato de que a incorporação das TDIC à educação não prescinde da adesão dos professores e esta "adesão" ainda não foi conquistada.

O artigo de Silva e Garíglio (2010) busca discutir as práticas de formação continuada de professores para o uso das tecnologias da informação e comunicação no interior da atual política pública de inclusão digital, o projeto Escolas em Rede, implantado pela Secretaria de Estado da Educação de Minas Gerais (SEE-MG). Neste estudo de caso analisam-se as metodologias de ensino utilizadas nos processos de formação dos professores, assim como os ambientes de aprendizagem e materiais didáticos privilegiados nas ações do programa em questão. Buscando compreender paralelamente à visão dos professores, formadores e coordenadores envolvidos na proposta de capacitação, a pesquisa também é composta por entrevistas realizadas entre duas turmas de professores envolvidos na formação do projeto de inclusão digital. A análise dos dados da pesquisa demonstra que a política de inclusão digital da SEE-MG vem sofrendo dos mesmos problemas históricos de outras políticas públicas da área, como a escassez infraestrutura tecnológica de ponta e de pessoal para dar suporte às práticas de uso das TIC nas escolas. Além disso, há ainda um caráter de verticalização na implantação do projeto, considerando que em nenhum momento a política dialoga com a 
realidade dos professores e de suas escolas de origem, ocasionando um distanciamento entre o programa e as reais demandas das instituições de ensino e educadores da rede estadual.

A tese de Barcelos (2011) procura apresentar uma proposta de formação continuada como estratégia de mobilização de professores de matemática para o uso das TDIC. Seu objetivo é aplicar esta proposta de formação a alunos egressos da licenciatura em matemática do Instituto Federal Fluminense e avaliar seu impacto na prática docente. Através de questionários, entrevistas e observação das trocas ocorridas em ambiente virtual, a pesquisadora obteve algumas constatações: a) a necessidade de promoção do letramento digital como pré-condição para formações deste tipo; b) a importância de sujeitos mais experientes para mediação das trocas entre os pares; c) a flexibilidade da formação contribui para o atendimento às demandas dos professores; d) a possibilidade de compartilhar informações e experiências cria um espaço informal de trocas, o que motiva atividades formais; e) a identificação do capital social obtido por meio das atividades presenciais e conteúdos publicados na rede; e f) formações deste tipo são impactantes na prática do professor. Enquanto estratégia, o estudo de caso intitulado "Tecnologias na prática docente de professores de matemática: formação continuada com apoio de uma rede social na internet" aproxima-se bastante da presente pesquisa, na medida em que também olha para formação continuada docente específica e faz a análise de seus possíveis impactos no repensar ou ressignificar da relação do professor com as TDIC em sua prática profissional.

A tese "Formação continuada para a prática docente no paradigma da complexidade com uso das tecnologias da informação e comunicação", de Klammer (2011) procura investigar a formação pedagógica do professor universitário, no que tange o uso das Tecnologias Digitais da Informação e Comunicação em suas práticas. Seu objetivo é compreender como um programa lato senso de formação pedagógica continuada de uma universidade privada de Curitiba, Paraná, contribui para a prática docente na perspectiva do paradigma da complexidade, que acolha o uso das tecnologias em uma visão crítica. O estudo de caso se propôs a aplicar questionários a 48 professores com o objetivo de coletar dados e, em seguida, realizar entrevistas com um grupo menor de docentes. Sua tese discute sociedade, educação, tecnologia e formação docente a partir de novas reflexões e atitudes que indicam a necessidade da formação continuada, da dúvida e da incerteza constante e uma visão sistêmica, intercortada em uma grande teia de relações. A conclusão de sua pesquisa traz indicações primeiramente sobre a importância de se pensar a formação de professores em uma dimensão do paradigma da complexidade, exaltando o olhar holístico, para além de respostas 
definitivas, como parte do processo contínuo de formação de docentes universitários. Além disso, Klammer (2011) conclui que o curso de formação investigado provocou uma desestabilização das certezas docentes dos sujeitos de pesquisa, o que possibilita abrir portas para a ressignificação de suas práticas. Ao investigar um curso de formação docente específico, a pesquisa também dialoga com o presente estudo.

$\mathrm{Na}$ dissertação “Impressões digitais entre professores e estudantes: um estudo sobre o uso das TIC na formação inicial de professores nas universidades públicas de Santa Catarina”, Lara (2011) interessou-se por investigar o uso que professores e estudantes de sete cursos de licenciatura da Universidade do Estado de Santa Catarina (UDESC) e da Universidade Federal de Santa Catarina (UFSC) fazem das TDIC, com o objetivo de perceber sua presença nos cursos de formação de professores da educação básica. A pesquisa qualitativa parte do pressuposto de que os usos das TDIC em contextos sociais ou formativos são essenciais para sedimentar a incorporação das tecnologias nas práticas educativas e que a formação inicial de professores tem relevância central neste processo. O estudo constata que o conhecimento dos professores universitários em relação ao uso das TDIC é inferior ao de seus alunos e que a universidade pouco faz para promover vivências de ambos no contexto da cibercultura. Além disso, os questionários aplicados demonstram que professores e alunos compreendem as TDIC a partir de uma perspectiva bastante instrumental e restritiva, como mera ferramenta de trabalho.

Machado (2011), em sua pesquisa "Informática educativa: elementos para uma proposta de formação continuada de professores" tece importantes reflexões acerca do conflito geracional existente na escola: jovens e crianças inseridas no contexto da cibercultura e uso intenso das TDIC, em relação a professores que fazem uso ainda incipiente das tecnologias em suas práticas pedagógicas. O autor caracteriza o docente como sujeito fundamental na modernização do processo de ensino-aprendizagem, procedendo a uma análise das políticas públicas de formação para a informática educativa. Pela análise das estruturas curriculares dos cursos de licenciatura da Universidade de Passo Fundo e de entrevistas com alunos e professores em diferentes momentos da carreira, além de formadores do Núcleo de Tecnologia Educacional da rede pública municipal, o autor também adverte para a necessidade de mudanças substanciais na formação universitária de professores. Também sugere alguns elementos para se pensar a formação continuada de docentes, no sentido de integrar essas tecnologias ao cotidiano escolar, de modo a proporcionar sua modernização e renovação. Trata-se, portanto, de um estudo que parte da crítica da formação 
inicial, para sugerir novas abordagens para a formação continuada de professores para o uso educacional das TDIC. Ele aproxima-se do presente estudo em sua perspectiva de formação docente: valorização da formação continuada como condição para o adequado uso educacional das TDIC.

O trabalho realizado por Maia (2011) configura-se como análise do impacto de um curso de formação em EAD, na preparação do professor para o uso educacional das TDIC. A dissertação "Formação para o ensino de ciências e o uso de tecnologias da informação e comunicação, um estudo de caso" compara, por meio de dados obtidos por meio de entrevistas e questionários, alunos dos cursos de Licenciatura em Biologia oferecidos pela Universidade de Brasília, nas modalidades presencial e a distância. O estudo verificou a ausência de disciplinas que tratem do uso das TDIC no ensino de biologia e uma aprendizagem transversal, assimétrica e não formal nos dois grupos de alunos. Os estudantes que cursam a licenciatura na modalidade EAD, de acordo com os dados obtidos, não possuem conhecimento mais amplo sobre as TDIC e suas possibilidades de uso em sala de aula, mas, ainda assim, tendem a fazer mais usos delas em sua prática de ensino.

Placido (2011), em sua dissertação "Formação continuada de professores: análise sobre o uso das tecnologias da informação e comunicação - TIC na organização do trabalho pedagógico" procura compreender se o processo de formação continuada de professores, oferecido pelo PROINFO para o uso pedagógico das TDIC tem alterado qualitativamente a organização do trabalho pedagógico. Por meio de entrevistas com professores envolvidos no programa, os dados coletados são analisados à luz das metodologias dos cursos de formação promovidos pelo PROINFO, da infraestrutura das escolas e da prática pedagógica. $\mathrm{O}$ resultado da pesquisa indica que os cursos ainda não atingiram seus objetivos de incluir a escola no contexto da cultura digital, apesar de os professores perceberem a importância das TDIC e terem participado das formações ofertadas pelo programa, isto porque afirmam não se sentirem preparados para a inserção dos recursos em suas práticas em sala de aula. Esse resultado indica a falha da formação continuada do programa para efetiva transformação do papel do professor no que se refere ao uso pedagógico das TDIC.

A pesquisa de Procópio (2011) analisa as implicações da formação de professores, por meio das tecnologias digitais da informação e comunicação, em um curso de Pedagogia na modalidade EAD, no que se refere a sua prática na sala de aula e suas relações com as tecnologias, isto é, de que forma a formação em EAD, que faz uso constante de ferramentas tecnológicas pode contribuir ou transformar o trabalho docente. Por meio de entrevistas e 
questionários aplicados a professores formados pelo curso oferecido pela Universidade Federal de Juiz de Fora, a pesquisadora pode investigar se o professor formado por meio das tecnologias utilizaria mais essas TIC como mediação pedagógica em sua prática docente, em comparação com o seu trabalho anterior a sua formação. Os dados obtidos permitiram perceber que os professores formados em pedagogia pela modalidade EAD fazem uso dos meios tecnológicos em sua vida cotidiana e profissional. Entretanto, esse uso conforma-se mais na questão da preparação de aulas, na interação nas redes sociais e buscas de pesquisa. Os possíveis motivos para a limitação ou uso incipiente e instrumental das tecnologias como recurso pedagógico referem-se à ausência ou precariedade de sala de informática das escolas e falta de incentivo dos coordenadores pedagógicos, que compreendem o uso das TDIC como complemento de outras práticas mais centrais ao trabalho docente.

A dissertação de Salesi (2011) investiga os reflexos causados pela inserção da temática das TDIC no cotidiano escolar dos alunos de graduação do curso de Licenciatura em Pedagogia da Universidade do Oeste Paulista que tiveram a incorporação de duas novas disciplinas em sua grade curricular: Tecnologias e Educação I e Tecnologias e Educação II. Para coleta de dados, a pesquisadora, que também ministrou as duas disciplinas, entrevistou nove de seus alunos, com o objetivo de compreender quais influências e aprendizagens, conduzidas pelas disciplinas, poderiam trazer para o processo de formação de tais professores e consequentemente para sua futura prática pedagógica. Os dados analisados indicam mudanças positivas na compreensão destes alunos acerca do papel do professor e das TDIC na escola, indicando possibilidades de atuação profissional, em convergência com a perspectiva crítica e reflexiva.

Em "Informática e educação: formação de professores e políticas públicas”, Santos (2011) apresenta um panorama das políticas públicas relacionadas à informática e educação, incluindo as de formação de pessoal no estado do Rio de Janeiro. O programa Conexão Professor lançado pelo Governo do Estado que distribuiu notebooks para os professores da rede com a finalidade de oferecer acesso às TDIC foi analisado com o objetivo de investigar o que estava sendo feito com o aparato tecnológico recebido e se algum tipo de formação para a utilização dos dispositivos foi oferecida para os educadores e como se deu a participação dos docentes na implementação e realização do programa. Trata-se de uma pesquisa exploratória em três municípios do estado, com a utilização de questionários fechados aplicados a professores que receberam os notebooks do programa. Os dados apontam que a maior parte dos decentes pesquisados ainda está sendo iniciado ao uso das novas tecnologias no âmbito 
pessoal e ainda não as utilizam no âmbito profissional, ou seja, não fazem uso dos novos aparatos tecnológicos disponíveis nas escolas com seus alunos. Segundo a autora, a ausência de formação continuada para os docentes é a principal causa para a morosidade no efetivo uso pedagógico da tecnologia. Em confluência com esta pesquisa, a formação inicial e continuada dos profissionais da educação para o uso pedagógico do computador, de acordo com as conclusões de Santos (2011), deve ser tratada como prioridade pelas políticas públicas, caso contrário, os investimentos em equipamentos e infraestrutura se esvaziam.

Schrainer (2011) apresenta em sua dissertação a análise do uso educacional das TDIC em duas escolas, uma pública e uma privada, do estado do Paraná. Intitulado "Formação de professores e as possibilidades de utilização das tecnologias da informação e comunicação na aprendizagem", seu trabalho considera a formação do professor como elemento fundamental à promoção de uma educação inovadora, democrática e humana e, nesta esfera, considera as TDIC como mobilizadoras desta postura. Por meio de questionários aplicados a alunos de ambas as escolas e entrevistas, a partir de grupos focais com professores, a pesquisadora observou que a utilização dos recursos tecnológicos nos ambientes escolares em estudo não garante a prática de uma educação inovadora. Por conta das deficiências na formação docente, alguns educadores acabam por desenvolver com as TDIC a mera reprodução de estratégias tradicionais, o que não favorece a tomada de consciência de seus alunos. Apesar de sua pesquisa não se ocupar da análise da formação em si, ela também aponta, por meio de seus dados, para a necessidade da abrangência do campo do uso pedagógico das TDIC em formação continuada, como estratégia para superação da reprodução das velhas práticas por práticas verdadeiramente inovadoras. Trata-se, mais uma vez, de uma proposição de superação da perspectiva instrumental do uso das TDIC na educação por meio de uma formação continuada crítica e reflexiva.

A dissertação "As tecnologias da informação e comunicação na formação inicial de professores de matemática em Recife e região metropolitana”, de Silva (2011) procura também investigar a formação inicial de professores para o uso pedagógico das TDIC, mas com foco em seis cursos de licenciatura em Matemática na região do Recife, Pernambuco. Por meio da análise documental de projetos pedagógicos e grades curriculares dos cursos e entrevistas com professores e estudantes concluintes dos mesmos, o autor verifica incipiência e timidez na inserção das TDIC nestes centros de formação de professores. A formação para o uso educacional das TDIC é compreendida como transversal e integradora de todas as 
disciplinas do curso, o que releva a necessidade de mudança de paradigma na formação inicial de professores licenciados em Matemática.

O trabalho de Turiani (2011), "Formação continuada de professores e TIC: contribuições do Curso Mídias na Educação", investiga professores da rede pública que participaram do curso "Mídias na Educação", um programa de formação continuada na modalidade EAD promovido pelo MEC e universidades conveniadas. Seu objetivo é obter, a partir da percepção dos professores, as contribuições importantes que este curso ofereceu para suas práticas pedagógicas, a forma como adquirem conhecimento e como ensinam sua disciplina ao aluno. Por meio de questionários, o autor analisa como o curso impacta nos processos de construção de conhecimento, bem como a utilização prática dos conhecimentos adquiridos ou produzidos no decorrer da formação. Suas conclusões indicam que os professores ampliaram seus conhecimentos e seu repertório de saberes profissionais docentes, além de exaltar a possibilidade do compartilhamento de práticas entre os pares, pela adoção do modelo de formação continuada na modalidade EAD. Este trabalho também se aproxima da presente pesquisa, na medida em que procura analisar o impacto de um curso de formação continuada para o uso educacional das TDIC na perspectiva do professor em formação.

A dissertação de Zuffo (2011) contribui significativamente para compreensão deste campo de pesquisa, porque procura construir um estado da arte de teses e dissertações sobre a formação de professores para o uso das tecnologias educacionais no Brasil, entre 2003 e 2008. Em sua pesquisa, o autor investigou os resumos de 97 dissertações e teses, relacionando as características metodológicas destas pesquisas, a abordagem, os tipos de estudo, os tipos de análise e de amostragem. Além disso, o trabalho também procura identificar aspectos que são abordados ou silenciados nas pesquisas sobre formação de professores para o uso educacional das tecnologias. O estudo "A formação de professores para o uso das tecnologias educacionais: o que apontam as teses e dissertações defendidas no Brasil entre 2003 e 2008" indica como tema abordado de forma recorrente o caráter burocrático apresentado pelo programa PROINFO e assinala diversas lacunas no processo de formação de professores e no próprio trabalho pedagógico com uso de tecnologias, especialmente por conta da falta de infraestrutura e políticas públicas no setor. Segundo Zuffo (2011), em similitude com a perspectiva defendida na presente pesquisa, o principal ponto silenciado neste levantamento é a necessidade de garantir uma formação que vá além da mera instrumentalização das tecnologias inseridas na escola, mas que leve em conta uma apropriação crítica e reflexiva desses recursos. 
Carvalho (2012), por sua vez, aborda a questão do uso das TDIC no contexto de ensino-aprendizagem de Língua Portuguesa e suas interações na formação do professor. A dissertação "Tecnologia da informação e da comunicação (TIC) e ensino-aprendizagem de língua portuguesa: implicações na formação do professor" entrevista gestores, professores e alunos da rede pública municipal de Taubaté, interior de São Paulo, partindo da hipótese, mais tarde confirmada, de que há insuficiência nos equipamentos tecnológicos disponíveis na escola da rede e de que estes equipamentos não estariam sendo utilizados por docentes de Língua Portuguesa para a prática do multiletramento ${ }^{8}$. A partir desta constatação, o autor investiga as grades curriculares de três cursos de licenciatura em Língua Portuguesa de três universidades do estado de São Paulo, com o objetivo de identificar ou não a presença de formação específica para o uso pedagógico das TDIC. Por fim, conclui que a formação inicial de professores de Língua Portuguesa é falha no que se refere à inserção de práticas de multiletramento com uso das TDIC.

A pesquisa intitulada "De contextos do fazer pedagógico: entre formação continuada e tecnologias da informação e comunicação", de Frozi (2012) é um estudo de caso que objetiva observar qual a influência das Tecnologias da Informação e Comunicação no fazer pedagógico dos professores de uma escola estadual do Mato Grosso, a partir dos pressupostos da formação continuada, na modalidade semipresencial oferecida pelo MEC, via plataforma E-PROINFO ${ }^{9}$. A pesquisa de tipo exploratório descritiva fez uso de questionários aplicados aos professores e observações no próprio locus de pesquisa. Os resultados revelam que, apesar de tímidas, há tentativas interessantes quanto ao uso das TDIC no cotidiano da escola, mas ainda bastante restritas ao uso instrumental, como uma extensão do livro didático. São evidentes as fragilidades da escola no que diz respeito à implantação de laboratórios de informática e outros espaços e que estes estejam articulados com os objetivos da aprendizagem. A autora conclui também que a formação continuada pode contribuir para que novos contextos surjam na prática docente, no que diz respeito ao uso integrado das TDIC, reflexão que se coaduna com o pressuposto da presente pesquisa, que compreende a formação continuada como espaço estratégico para mobilização dos docentes quanto ao uso pedagógico das TDIC.

\footnotetext{
8 "É uma palavra que se refere tanto a multimodalidade das mídias digitais, quanto a multiplicidade de práticas de letramento que circulam em diferentes esferas da sociedade, bem como a multiculturalidade (...) remete, principalmente, ao fato de que tornar-se um leitor proficiente no contexto da contemporaneidade, marcada inclusive pela presença das tecnologias e de múltiplas semioses exige uma certa capacidade de compreensão para atribuição de sentido a textos de diversos gêneros" (CARVALHO, 2012).

${ }_{9}^{9}$ Plataforma digital do Programa Nacional de Tecnologia Educacional (PROINFO/MEC).
} 
Iglesias (2012), em sua dissertação “A formação do pedagogo e as tecnologias educacionais: realidade ou ficção?" pesquisa a forma como as propostas curriculares dos cursos de Pedagogia das instituições públicas federais da Região Sul do Brasil estão contemplando a formação para o uso e compreensão crítica das tecnologias educacionais no processo de ensino. Segundo a autora, as transformações sociais orientadas pelo avanço das TDIC e a sua presença nos contextos escolares demandam um novo fazer pedagógico e, para que isto ocorra, o professor e o coordenador pedagógico precisam de uma formação que os prepare para a superação do uso operacional e os aproxime do uso pedagógico das tecnologias. Neste sentido, a pesquisa de tipo documental analisou as propostas curriculares (ementas, grades curriculares e propostas pedagógicas) de 37 instituições públicas dos estados do Paraná, Santa Catarina e Rio Grande do Sul. Os dados indicam evolução e transposição de uma perspectiva instrumental/operacional para uma concepção que compreende as tecnologias como parte do processo de construção do conhecimento. O limite, entretanto, ainda é a reduzida carga horária dispensada às disciplinas que tratam da questão e a época em que elas são ofertadas durante a formação inicial, o que caracteriza a falta de atenção dada às necessidades da formação do pedagogo para o uso educacional das TDIC. Apesar dos dados positivos a autora ressalta os limites impostos pela carga horária docente reduzida para ações de formação continuada.

A dissertação de Milhomem (2012) faz uma análise sobre o uso das novas tecnologias na educação, em especial o computador, relacionadas à formação inicial de professores para o uso desses recursos na educação básica. A pesquisa qualitativa tem como objetivo principal analisar o que está sendo feito nos cursos de formação inicial de professores do campus universitário “Jane Vanini”, UNEMAT/Cáceres, Mato Grosso, com relação à formação para o uso do computador na educação básica. Foram analisados os Parâmetros Curriculares Nacionais para o Ensino Fundamental e Médio, as Diretrizes Gerais para Formação de Professores e os Projetos Pedagógicos de oito licenciaturas envolvidas na pesquisa, além da aplicação de questionários a professores dos mesmos cursos. Os dados obtidos permitiram perceber, em conclusão, a existência de uma contraposição entre o que é o ideal e o real. No campo do ideal, há o reconhecimento da importância e necessidade de uso das TIC na educação, mas no campo do real, observa-se que os professores, em raras exceções, fazem uso das TIC, mas não sabem utilizá-las em sua prática pedagógica, revelando a necessidade de atenção especial à formação inicial e continuada. 
Em artigo apresentado na $36^{\mathrm{a}}$ Reunião Nacional da ANPEd, Silva (2013) discute os resultados de sua pesquisa cujo objetivo geral consistiu em identificar e analisar os pressupostos teóricos e metodológicos que norteiam a prática de professores dos anos iniciais, no uso do computador no processo ensino e aprendizagem, relacionando-os ao objetivo específico de analisar a inserção do computador na educação escolar e suas relações com a formação docente sob a perspectiva do professor pesquisado. Por meio da aplicação de questionários a professores de uma rede municipal no interior de São Paulo que participaram de formação continuada de um programa de inclusão digital, a pesquisa qualitativa obteve conclusões que demonstram que os computadores são incorporados na dinâmica escolar sem o devido investimento em formação continuada docente. Com uma prática pedagógica já consolidada, os professores se veem impelidos a utilizar uma ferramenta não comum ao seu cotidiano. Os resultados dessa pesquisa indicam, portanto, que a formação docente para o uso do computador na educação escolar deve ter suas bases em políticas estruturadas que considerem os desejos, necessidades e contexto profissional dos professores. Para isto, faz-se necessário pensar em uma formação centrada na escola, crítica e reflexiva, que leve em conta as especificidade de cada dinâmica escolar.

Diante deste quadro de artigos, dissertações e teses publicadas na última década sobre a formação de professores para o uso educacional das TDIC, é possível observar algumas tendências deste campo de pesquisa. Com exceção dos trabalhos de Tozetto (2008) e Klammer (2011), todas as pesquisas apresentadas tratam da formação de professores da educação básica. No entanto, vale ressaltar a inexistência de pesquisas que relacionem a formação de professores para o uso pedagógico das TDIC e a educação de jovens e adultos, o que indica a relevância científica da presente pesquisa.

Os trabalhos de Barros (2007), Tozetto (2008), Gargílio (2010), Barcelos (2011), Klammer (2011), Lara (2011), Placido (2011), Santos (2011), Schrainer (2011), Turiani (2011), Frozi (2012) e Silva (2013) tratam, assim como a presente pesquisa, de cursos de formação continuada de professores, enquanto os demais analisam a formação inicial de docentes, em cursos de licenciatura. De modo geral, a percepção dos autores sobre a formação continuada é de que ela ainda é bastante insuficiente, nos diferentes contextos investigados. Notadamente, nos trabalhos de Santos (2009), Tozetto (2008), Lara (2011), Procópio (2011), Schrainer (2011) e Frozi (2012), os dados indicam que os professores fazem uso das TDIC em uma perspectiva instrumental, como extensão do livro didático ou reprodução das práticas tradicionais de ensino e aprendizagem. 
Algumas pesquisas dialogam mais com o presente estudo de caso, porque muito mais do que observar a insuficiência da formação nos contextos em tela, apresentam propostas de formação continuada de professores para o uso educacional das TDIC. Barros (2007), Barcelos (2011) e Machado (2011) procuram sugerir estratégias ou relatar práticas de sucessos com este tipo de formação. Os trabalhos de Barcelos (2011), Maia (2011), Procópio (2011), Turiani (2011) e Silva (2013) também se relacionam com este estudo, por trazerem análises sobre o impacto ou os efeitos de cursos de formação, no repensar ou na prática docente de professores da educação básica para o uso das TDIC.

Ao aproximar os campos de intersecção entre os estudos sobre a EJA, formação de professores e uso educacional das TDIC, a partir dos 39 trabalhos comentados nesta revisão de literatura, pode-se pensar em três constatações que justificam esta pesquisa. A primeira delas é a escassez de estudos sobre a formação de professores para o uso das TDIC no contexto da EJA. Os estudos de caso envolvem instituições da educação superior ou da educação básica, mas nenhum trata especificamente de um centro especializado na formação de jovens e adultos. Em segundo lugar, foi possível constatar a existência de poucos trabalhos que apresentem experiências bem sucedidas de formação continuada de professores para o uso educacional das TDIC. A maior parte dos estudos relata a insuficiência das formações, a ineficiência do uso das tecnologias nas práticas dos docentes ou a ineficácia das políticas públicas do setor, mas não apresenta propostas novas ou ações de sucesso que possam servir de exemplo para gestores e formadores de professores. Por fim, os estudos apresentados convergem para um fator determinante e urgente para a ampliação das possibilidades de transformação qualitativa da relação entre a escola e a cibercultura: é, mais do que nunca, necessário superar a perspectiva técnica e instrumental, até então hegemônica, na integração das TDIC às práticas escolares e substituí-la por uma visão mais crítica, reflexiva e que se ampare na constituição do professor como profissional da educação que pode desempenhar sua função erguido em meio à perspectiva autoral. Nesse sentido, acredita-se que a formação inicial e as ações de formação continuada de professores, como o curso em análise no presente estudo, podem se consubstanciar como instância contribuinte para a efetivação deste ideal. E é justamente a validade dessa suposição que o presente estudo pretende investigar. 


\section{CAPÍTULO 2 - A FORMAÇÃO CONTINUADA EM SERVIÇO DE PROFESSORES DA EJA PARA O USO PEDAGÓgICO DAS TDIC: DIÁlOgOS SOB UMA PERSPECTIVA CRÍTICO-REFLEXIVA}

A formação de professores vem nas últimas duas décadas se constituindo como um campo autônomo de estudos, como afirma André (2010b). Há um crescente interesse dos pesquisadores pelas questões relacionadas à formação do professor e ao trabalho docente, o que vem provocando aumento da produção científica sobre o tema (ANDRÉ, 2010a). Surgem, a cada ano, eventos e publicações especialmente dedicadas às questões da formação docente.

Para André (2010b), a formação de professores constitui-se cada vez mais como um campo autônomo de estudos por possuir um objeto próprio, metodologias específicas, uma comunidade de cientistas com um código de comunicação próprio, integração dos pesquisadores no desenvolvimento da pesquisa e reconhecimento da formação de professores como um elemento fundamental na qualidade da ação educativa.

Além do mais, tem sido cada vez mais constante a visibilidade do tema na mídia, por meio de discussões sobre o professor, seu papel e sua formação. Nóvoa (1999) denuncia o discurso inflado acerca da importância do professor frente aos "desafios do futuro". Segundo o educador português, as atenções dos políticos e da opinião pública se viram para os professores quando outras respostas para os problemas educacionais, ou para os problemas sociais, não são encontradas. Apesar disso, não se veem propostas coerentes sobre a formação docente:

\footnotetext{
Por um lado, os professores são olhados com desconfiança, acusados de serem profissionais medíocres e de terem uma formação deficiente; por outro lado, são bombardeados com uma retórica cada vez mais abundante que os considera elementos essenciais para a melhoria da qualidade do ensino e para o progresso social e cultural (NÓVOA, 1999, p. 13-14).
}

Ao mesmo tempo, entretanto, é “impossível imaginar alguma mudança que não passe pela formação de professores" (NÓVOA, 1999, p.18). Neste sentido, a questão da formação docente não pode mais ser pensada como a panaceia de todos os males da educação, mas também é preciso ter cuidado para não se tornar apenas um espaço de profusão de teorias da moda. Das discussões sobre formação de professores não têm emergido propostas concretas. Há, na verdade, um completo desarranjo de propostas, pois, no campo da formação docente, "nem sempre se procura e se consegue distinguir entre o que são exercícios de um jargão da 
moda daquilo que tem respaldo em investigações teóricas e empíricas” (AZANHA, 2004, p. $370)$.

Com base nas reflexões destes autores e em diálogo com Giroux (1997), Nóvoa (1995, 1999), Freire (2001; 2002), Imbernón (2000), Azanha (2004; 2006) e Tardif (2014) busco, primeiramente, desenhar neste capítulo uma concepção da formação de professores a partir da perspectiva crítico-reflexiva, procurando romper com a perspectiva técnica, de simples aplicação de metodologias de ensino, ou com a perspectiva cientificista, que compreende o professor como mero aplicador de teorias pensadas pelas ciências da educação. Em um segundo momento, procuro tratar com mais especificidade da formação continuada em serviço, com o objetivo de desenvolver reflexões que contribuam para melhor fundamentação e compreensão do curso de formação em tela. Com base em autores como Levy (1999), Belloni (1998), Assmann (2005), Porto (2006) e Pretto e Assis (2008) trato da formação de professores no contexto da cibercultura e das transformações que dela decorrem nas ações pedagógicas, ou seja, a formação de professores para o uso educacional das TDIC. Por fim, procuro traçar algumas considerações acerca da formação de professores para a Educação de Jovens e Adultos, com base em Ribeiro (1999), Di Pierro (2005a; 2010b), Arroyo (2006), Soares (2008; 2011), Moura (2009) e Vóvio (2010).

\subsection{A formação de professores na perspectiva crítica-reflexiva}

Na concepção de Imbernón (2002), a formação docente é um processo contínuo de desenvolvimento profissional, que tem início na experiência escolar e prossegue ao longo da vida. Isto significa dizer que a formação está além dos momentos especiais reservados para aperfeiçoamento e abrange questões relativas a salário, carreira, estruturas e participação em decisões. Partindo desta concepção, é possível compreender que a formação docente ultrapassa os limites da dicotomia entre formação inicial e formação continuada e deve ser pensada em seu sentido mais amplo.

A formação de professores é um campo de tensões e conflitos porque não está vinculada apenas a uma ocupação no mercado de trabalho, trata-se também de uma disputa pelo controle do campo social docente (NÓVOA, 1995). Ao longo da história da educação no Brasil, por exemplo, os programas de formação docente sempre atenderam às demandas de uma classe social que, por meio da educação, busca legitimar seu projeto político. No século XIX “as primeiras iniciativas pertinentes à criação de escolas normais coincidem com a hegemonia do grupo conservador, resultando das ações por ele desenvolvidas para consolidar sua supremacia e impor seu projeto político" (TANURI, 2000, p. 63). Este processo é 
elemento característico do controle do Estado sobre o exercício docente. "O professorado constituiu-se em profissão graças à intervenção e ao enquadramento do Estado, que substituiu a Igreja como entidade de tutela do ensino" (NÓVOA, 1995, p. 29).

O controle externo do exercício docente é um entrave para a concepção de uma formação pautada por um projeto coletivo e que leve em conta os saberes profissionais produzidos pela ação coletiva dos professores. Este processo acaba muitas vezes levando o docente ao papel passivo de funcionário ao invés de assumir-se enquanto profissional autônomo. De acordo com Nóvoa (1995), a consolidação das instituições de formação de professores representa, ao mesmo tempo, um reforço do controle estatal e uma maior afirmação de sua autonomia. Este movimento representa uma característica central do exercício docente, o que Enguita (1991) qualificou como a "ambiguidade da docência". Segundo o autor, a profissão docente está em um lugar intermediário entre a profissionalização e a proletarização, isto é, ao mesmo tempo em que o professor é submetido à autoridade do Estado, luta por manter ou ampliar sua autonomia no processo de trabalho. A formação docente é um dos campos em que esta ambiguidade reside. Ela possui um "papel importante na configuração de uma 'nova' profissionalidade docente, estimulando a emergência de uma cultura profissional no seio do professorado e de uma cultura organizacional no seio das escolas" (NÓVOA, 1995, p. 24).

A perspectiva da formação docente sugerida por estes autores se contrapõe à "tendência de reduzir os professores ao status de técnicos especializados dentro da burocracia escolar, cuja função, então, torna-se administrar e implementar programas curriculares" (GIROUX, 1997, p. 158). Trata-se de uma perspectiva crítico-reflexiva que supõe o professor como intelectual transformador, refuta a concepção instrumental e técnica da docência e valoriza os saberes mobilizados pelos docentes: os saberes de uma prática reflexiva, os saberes de uma teoria especializada e os saberes de uma militância política (NÓVOA, 1999).

De acordo com as principais referências neste novo campo, os programas de formação de professores, sejam de formação inicial ou continuada, possuem, de modo geral, deficiências científicas e pobreza conceitual. "A adequada formação do professor não pode ser imaginada como a simples e direta aplicação à situação de ensino de um saber teórico" (AZANHA, 2006, p. 57). Neste sentido, um caminho viável é “encontrar processos que valorizem a sistematização dos saberes próprios, a capacidade para transformar a experiência em conhecimento e a formalização de um saber profissional de referência" (NÓVOA, 1999, p. 18). 
Para Nóvoa (1995; 1999), a formação de professores deve articular três dimensões: o desenvolvimento pessoal, o desenvolvimento profissional e o desenvolvimento organizacional. A primeira refere-se ao trabalho de reflexão crítica sobre as práticas docentes e permanente reconstrução de uma identidade pessoal. Ela pressupõe um investimento e valorização da experiência do professor como um saber fundamental para sua identidade pessoal e profissional.

A formação deve estimular uma perspectiva crítico-reflexiva, que forneça aos professores os meios de um pensamento autônomo e que facilite as dinâmicas de autoformação participada. Estar em formação implica um investimento pessoal, um trabalho livre e criativo sobre os percursos e os projetos próprios, com vista à construção de uma identidade, que é também profissional (NÓVOA, 1995, p. 25).

O desenvolvimento profissional refere-se às práticas coletivas de produção da profissão docente. "Práticas de formação que tomem como referência as dimensões coletivas contribuem para a emancipação profissional e para a consolidação de uma profissão que é autônoma na produção dos seus saberes e dos seus valores" (NÓVOA, 1995, p. 27). Para que o desenvolvimento profissional se efetive, é preciso repensar as práticas de associativismo docente, no sentido de contribuir para a formação de "um ator coletivo, portador de uma memória e de representações comuns, que cria linguagens próprias, rotinas partilhadas de ação, espaços de cooperação e dinâmicas de co-formação participada" (NÓVOA, 1999, p. 19).

O desenvolvimento organizacional, por sua vez, refere-se ao projeto da escola, em uma perspectiva em que não haja distinção entre trabalho e formação, isto é, "a formação deve ser encarada como um processo permanente, integrado no dia-a-dia dos professores e das escolas, e não como uma função que intervém à margem dos projetos profissionais e organizacionais" (NÓVOA, 1995, p. 29).

A proposta central para a criação de uma nova cultura de formação de professores, segundo Nóvoa (1995; 1999), está ligada ao associativismo e às possibilidades de partilha dos saberes docente. A identidade profissional do professor pode ser garantida pela consolidação de dispositivos de colaboração e de autoformação participada. "A troca de experiências e a partilha de saberes consolidam espaços de formação mútua, nos quais cada professor é chamado a desempenhar, simultaneamente, o papel de formador e de formando" (NÓVOA, 1995, p. 26).

Em confluência com essas ideias, o educador canadense Tardif (2014) salienta que "se os professores são, efetivamente, sujeitos do conhecimento, devem fazer, então, o esforço de 
agir como tais, ou seja, o esforço de se tornarem atores capazes de nomear, de objetivar e de partilhar sua própria prática e sua vivência profissional” (TARDIF, 2014, p. 240). Esta perspectiva, no entanto, pressupõe, para este autor, três mudanças substanciais nas concepções e nas práticas vigentes de formação de professores: a) é preciso reconhecer que, na medida em que os professores de profissão são de fato sujeitos do conhecimento, deveriam ter o direito de dizer algo a respeito de sua própria formação profissional; b) como o trabalho dos professores exige conhecimentos específicos a sua profissão e dela oriundos, então a formação de professores deveria, em boa parte, basear-se nesses conhecimentos, isto é, inserir conhecimentos práticos baseados nos saberes profissionais no próprio currículo dos cursos de formação; c) por fim, é preciso questionar as lógicas disciplinares dos cursos de formação de professores, abrindo espaço para uma lógica de formação profissional baseada na análise das práticas, das tarefas e dos conhecimentos dos professores de profissão, por meio de um enfoque reflexivo (TARDIF, 2014).

Para Azanha (2004), o desarranjo nas propostas de formação docente explica-se pelo fato de a realidade escolar contemporânea não ser levada em consideração no desenho dos programas de formação docente. É preciso levar em conta o próprio conceito de escola, sua nova e complexa conjuntura, além de suas especificidades locais.

Novas propostas de formação docente devem partir do próprio conceito de escola, não apenas como é formulado pela eventual contribuição de teorias da Sociologia, da Antropologia, da Administração e de outras áreas do conhecimento que se propõem descrever e explicar fatos da vida escolar, mas também pelo desenvolvimento de um ponto de vista pedagógico que leve em conta esses fatos na ordenação desejável das atividades escolares (AZANHA, 2004, p. 373).

O autor tece críticas acerca do tratamento da formação docente como simples aplicação de saberes metodológicos, assim como a mera aplicação de saberes teóricos. Tratase de um esforço de compreensão da escola como um projeto institucional, para transformá-la em uma comunidade fundamentada em uma visão ética cujos efeitos educativos podem se prolongar para além dos anos de escolaridade (AZANHA, 2004). Assim, sua proposta rompe com a ideia de centralização das normas gerais de formação de professores, concedendo espaço para pensar a formação no seio da própria escola e da própria reflexão acerca de sua prática profissional.

Para argumentar em favor do olhar reflexivo sobre a prática do professor, é fundamental considerar o aporte teórico trazido pelo educador Paulo Freire. Segundo Silva e Araújo (2005), apesar da orientação teórica-conceitual crítico-reflexiva ser apontada por 
diferentes estudos como a mais adequada para a formação de professor, as pesquisas não vêm levando em conta a relevante contribuição deste pensador. Para Freire (2001), a reflexão crítica permanente deve constituir-se como orientação prioritária para a formação continuada de professores que buscam a transformação por meio da prática educativa. Ela é o "movimento realizado entre o fazer e o pensar, entre o pensar e o fazer, ou seja, no "pensar para o fazer' e no 'pensar sobre o fazer'. Nesta direção, a reflexão surge da curiosidade sobre a prática" (SILVA e ARAÚJO, 2005, p. 4)

Além da noção de reflexão crítica, Freire (2002) também leva em conta a necessidade da formação permanente, ao afirmar que o homem é um ser inconcluso e deve ser consciente de sua inconclusão, através do movimento permanente de ser mais. Trata-se da condição de inacabamento do ser humano e consciência desse inacabamento.

Desta forma não basta refletir sobre a prática pedagógica docente, é preciso refletir criticamente e de modo permanente. Este processo precisa estar apoiado em uma análise emancipatório-política, para que os professores em formação possam visualizar as operações de reflexão no seu contexto sóciopolítico-econômico-cultural mais amplo (SILVA e ARAÚJO, 2005, p. 5).

Neste sentido, Freire (2001) afirma que

[...] na formação permanente dos professores, o momento fundamental é o da reflexão crítica sobre a prática. É pensando criticamente a prática de hoje ou de ontem que se pode melhorar a próxima prática. O próprio discurso teórico, necessário à reflexão crítica, tem de ser de tal modo concreto que quase se confunda com a prática. O seu "distanciamento" epistemológico da prática enquanto objeto de sua análise, deve dela "aproximá-lo" ao máximo. Quanto melhor faça esta operação tanto mais inteligência ganha na prática em análise e maior comunicabilidade exerce em torno da superação da ingenuidade pela rigorosidade (FREIRE, 2001, p. 43-44).

A perspectiva freireana, além de embasar o conceito de formação crítico-reflexiva de professores, também contribuirá mais adiante para a construção do conceito de empoderamento, que serviu como uma das premissas para a elaboração do curso de formação de professores em serviço para o uso pedagógico das TDIC no contexto da EJA, objeto desta investigação.

Em síntese, as propostas de formação de professores a partir da perspectiva críticoreflexiva trazidas neste capítulo defendem um processo formativo em que as escolas sejam concebidas como espaços de formação de seus profissionais a partir da reflexão sobre sua prática e uma instituição especial para o desenvolvimento de uma democracia crítica. Neste sentido, Giroux (1997) defende a compreensão dos professores como intelectuais que 
combinam a reflexão e a prática, a serviço de uma educação que objetive formar cidadãos também reflexivos, críticos e ativos.

Num sentido mais amplo, os professores como intelectuais devem ser vistos em termos dos interesses políticos e ideológicos que estruturam a natureza do discurso, relações sociais em sala de aula e valores que eles legitimam em sua atividade de ensino. Com esta perspectiva em mente, gostaria de concluir que os professores deveriam se tornar intelectuais transformadores se quiserem educar os estudantes para serem cidadãos ativos e críticos (GIROUX, 1997, p.162-163).

O quadro teórico apresentado sinaliza a perspectiva adotada por esta pesquisa, ao lançar luz sobre a formação de professores. A perspectiva delineada por Giroux (1997), Nóvoa (1995; 1999), Freire (2001; 2002), Imbernón (2000), Azanha (2004; 2006) e Tardif (2014) configura-se como central para o embasamento teórico e análise dos dados coletados nesta pesquisa. Como a formação investigada ocorreu ao longo de encontros de professores em Aula de Trabalho Pedagógico Coletivo ${ }^{10}$ (ATPC), é preciso traçar também algumas considerações acerca da formação continuada em serviço.

\subsection{A formação continuada em serviço}

A formação continuada tem sido cada vez mais destacada em eventos acadêmicos, publicações e associações profissionais, principalmente como alternativa compensatória para elevar a qualidade da formação docente, preenchendo lacunas da formação inicial do professor. Os resultados das iniciativas de formação continuada, no entanto, tem demonstrado pouca efetividade para o avanço qualitativo da educação.

Os processos de formação continuada desenvolvidos desde os anos 1980, quer para atualização ou complementação de conhecimentos, quer para preparar a implementação de uma reforma educativa, não produziram os efeitos esperados. Entre as razões invocadas estão a dificuldade da formação em massa, a brevidade dos cursos, realizados nos limites dos recursos financeiros destinados, e a dificuldade de fornecer, pelos motivos citados, ou ainda pelo nível de preparação das instituições formadoras, os instrumentos e o apoio necessários para a realização das mudanças esperadas (GATTI e BARRETO, 2009, p.201).

De acordo com Gatti e Barreto (2009), a designação de formação continuada cobre um universo bastante heterogêneo de atividades, que envolve ações mais institucionalizadas, com organização formal e certificação, mas também iniciativas menos formais, organizadas nas

\footnotetext{
10 Na rede pública estadual de São Paulo, em 2012, a Hora de Trabalho Pedagógico Coletivo (HTPC) foi substituída pela Aula de Trabalho Pedagógico Coletivo (ATPC), devido à Resolução SE No 08 de 2012 que regulamentou a composição da jornada docente. $\mathrm{O}$ encontro semanal de docentes passou a ser contado em 50 minutos, podendo variar entre duas e três ATPC semanais, de acordo com a jornada de trabalho do professor (SÃO PAULO, 2012).
} 
horas de trabalho coletivo ou pelas trocas entre pares e grupos, mais próximos do fazer cotidiano na unidade escolar e na sala de aula.

Com a emergência da perspectiva crítico-reflexiva de formação docente, o conceito de formação continuada passou por reformulação, procurando superar a perspectiva de compensação da formação inicial deficitária, conceito de capacitação e aperfeiçoamento, substituindo-o pela noção de desenvolvimento profissional.

As propostas inspiradas no conceito de capacitação cedem lugar a um novo paradigma, mais centrado no potencial de autocrescimento do professor, no reconhecimento de uma base de conhecimentos já existente no seu cabedal de recursos profissionais, como suporte sobre o qual trabalhar novos conceitos e opções. As representações, atitudes, motivação dos professores passam a ser vistas como fatores de capital importância a se considerar na implementação de mudanças e na produção de inovações na prática educativa. O protagonismo do professor passa a ser valorizado e a ocupar o centro das atenções e intenções nos projetos de formação continuada. Novos modelos procuram superar a lógica de processos formativos que ignoram a trajetória percorrida pelo professor em seu exercício profissional (GATTI e BARRETO, 2009, p.202-3).

Esta concepção de formação pautada pela lógica do desenvolvimento profissional adere-se à noção de formação ao longo da vida profissional, em que o processo de formação é definido como um movimento orientado a responder aos desafios que se sucedem no início da carreira, o processo de desenvolvimento e os momentos mais avançados, quando o professor consolida e compartilha seus saberes docentes.

A educação continuada de professores assenta-se na concepção de educação que se realiza ao longo da vida. Essa concepção penetra o espírito da LDB e é clarificada em seu artigo $1^{\circ}$ : "A educação abrange os processos formativos que se desenvolvem na convivência humana, na vida familiar, no trabalho, nas instituições de ensino e pesquisa, nos movimentos sociais e organizações da Sociedade Civil e nas manifestações culturais" (BRZEZINSKI, 2008, p.1148).

Para Gatti e Barreto (2009), os modelos mais aceitos pela literatura educacional partem desta concepção, especialmente ações como as oficinas de reflexão sobre a prática e a formação centrada no fortalecimento institucional. Afinal, "são os saberes produzidos na escola, junto com outros colegas e alunos, que iluminam e dirigem as práticas mais significativas do processo de formação social e intelectual a que se dedicam professores e alunos" (COLLARES et al., 1999, p.211).

De acordo com Rego e Mello (2002), a introdução de processos formativos que utilizam a reflexão crítica sobre as práticas no contexto de um compromisso com o fortalecimento da escola implica ambientes propícios a trabalho coletivo e gestão 
participativa. As oficinas de reflexão sobre a prática e a formação centrada no fortalecimento institucional supõem transformações que ultrapassam as questões de envolvimento dos professores e de formação continuada propriamente dita, dado que demandam condições institucionais e estruturais propícias.

Nóvoa (1991), ao levantar reflexões para a educação continuada, tece cinco proposições fundamentais para seu sucesso, dentro da perspectiva crítico-reflexiva. Para ele, a formação contínua deve alimentar-se de perspectivas inovadoras, valorizar as atividades de autoformação participada e de formação mútua, alicerçar-se em uma reflexão na prática e sobre a prática, incentivar a participação de todos os professores em programas e em redes de colaboração e capitalizar as experiências inovadoras e as redes de cooperação existentes nos sistemas.

Entretanto, apesar da consolidação de uma concepção de formação continuada voltada para o desenvolvimento profissional ao longo da vida, poucas pesquisas, de acordo com o vasto levantamento de Gatti e Barreto (2009), apontam para a efetiva contribuição da formação continuada nas práticas docentes. Entre os fatores apontados como problemáticos pelos docentes em formação continuada, quatro justificam a importância do repensar a formação continuada à luz da centralidade no fortalecimento institucional, isto é, pensar a formação continuada em serviço no seio da unidade escolar: a) a formação continuada é organizada com pouca sintonia com as necessidades e dificuldades dos professores e da escola; b) os professores não participam das decisões acerca dos processos de formação aos quais são submetidos; c) os formadores não têm conhecimento dos contextos escolares e dos professores que estão a formar; d) os programas não preveem acompanhamento e apoio sistemático da prática pedagógica dos professores, que sentem dificuldade de entender a relação entre o programa desenvolvido e suas ações no cotidiano escolar.

Formação continuada em serviço, ou formação docente em serviço, são práticas formativas docentes que passam a ocorrer justapostas à experiência do ofício e, muitas vezes, no próprio local de trabalho. Ela está diretamente relacionada com a prática pedagógica e ao trabalho vivenciado diariamente pelo professor e aos seus saberes, que, por sua vez, são construídos na sua relação com outros professores e alunos.

A formação concomitante ao exercício do ofício inaugura, assim, uma nova racionalização da profissionalidade, e, por extensão, da constituição dos saberes docentes. De um ponto de vista teórico, tratava-se de um dispositivo tático que fez circular, de forma mais precisa e localizada no interior da profissão, modos de se pensar professor (AQUINO e MUSSI, 2001, p.216). 
A formação em serviço funcionou, ao longo do tempo, como um instrumento de "correção" do ofício docente, validando certos saberes, práticas e metodologias e condenando outros. Desta forma, ela “operou uma dilatação dos mecanismos de poder sobre a profissão, ao funcionar como campo de validação dos tipos de saber que deveriam circular no exercício mesmo da docência, indicando gradualmente maneiras de se proceder no ofício" (AQUINO e MUSSI, 2001, p.217).

A partir do final da década de 1970, diante da inserção de teorias críticas na realidade educacional brasileira, a concepção de formação passa a ser repensada, no sentido de conceber o professor como um profissional reflexivo e não mais como um executor de tarefas pensadas fora do contexto escolar. A formação em serviço, desta forma, passa a valorizar a escola como locus de formação continuada do professor, não mais no sentido de legitimar certas ideias e práticas, mas no sentido de

[...] considerar o professor como um agente dinâmico cultural, social e curricular, capaz de tomar decisões educativas, éticas e morais, de desenvolver o currículo em um contexto determinado e de elaborar projetos e materiais curriculares com a colaboração dos colegas, situando o processo em um contexto específico controlado pelo próprio coletivo (IMBERMÓN, 2000, p. 21).

A reflexão é, portanto, a essência da formação em serviço no contexto trazido pelas teorias críticas. Ela é condição para transformação da prática pedagógica do professor e para a dura tarefa de atender às exigências que se colocam para sua profissão nos dias atuais, além de contribuir para a formação do professor enquanto pessoa, constituindo-o como sujeito autônomo no mundo (NÓVOA, 1995). A formação em serviço, desta forma, refere-se "ao desenvolvimento contínuo e permanente do sujeito professor, em uma perspectiva que contempla o individual e o profissional, no coletivo, de maneira que um âmbito não se sobreponha ao outro" (PLACCO, 2010, p.02).

As principais experiências de formação em serviço na atualidade tendem a fomentar o papel crítico e reflexivo do professor,

[...] seja pelo reexame das crenças pedagógicas que compõem suas decisões cotidianas; seja pela narrativa de suas histórias de vida; seja pela análise dos campos de conhecimento com os quais o professor interage; seja pela problematização das finalidades e valor educativo das situações que promove; seja, em última instância, pela investigação das condições sociais e históricas que vêm atravessando a constituição de sua profissão (AQUINO e MUSSI, 2001, p.218).

Assim, é possível afirmar que a formação docente que leva em conta as dimensões coletivas da profissão, que oferece condições para o compartilhamento de saberes e que 
compreende que todo professor é, em certa medida, também um formador, pode contribuir significativamente para emancipação da profissão. Diante de problemas concretos do cotidiano do professor, a formação em serviço, na perspectiva crítico-reflexiva, convoca o docente a "saber-se sujeito do conhecimento, gestor primordial da prática educativa que desenvolve, investigador de si mesmo, experimentador autônomo de seu ofício, centro decisório das transformações que deverá operar em sua prática cotidiana" (AQUINO e MUSSI, 2001, p.220).

Tendo em vista estas dimensões do trabalho docente, Placco (2010) define cinco circunstâncias a que o processo de formação em serviço precisa atender:

a) estar, em primeiro lugar, atrelado ao projeto político-pedagógico, organizado e implementado pelos próprios profissionais da escola; b) ser planejado coletivamente pelos educadores da escola, liderados pelos seus gestores (direção, coordenação pedagógica); c) prever espaços e tempos para que os processos formativos a serem desencadeados possibilitem a participação de todos, a reflexão sobre os fundamentos necessários à docência e a relação desses fundamentos com a experiência docente de cada profissional; d) garantir que o compromisso, seja dos gestores, seja dos educadores da escola, esteja voltado para o alcance dos objetivos pedagógicos e do desenvolvimento profissional, além do aprimoramento da prática pedagógica dos professores; e) possibilitar processos avaliativos contínuos para que as necessidades emergentes da escola e do próprio processo formativo possam ser incluídas (PLACCO, 2010, p.03).

Estas circunstâncias elencadas pelo autor permitem que os professores aprendam sobre si, mergulhados no contexto de sua própria escola. A formação centrada na escola decorre da formação voltada para a reflexão sobre a prática do professor, abordando de forma crítica as relações e contribuições da teoria à ação pedagógica. Obviamente, valorizar a formação centrada na escola não significa desprestigiar outros espaços formativos, assim como não significa diminuir a responsabilidade da formação inicial universitária. É preciso articular as diferentes instâncias de formação, inicial e continuada, para que ela seja compreendida como um processo. Canário (1999) destaca que uma das dimensões fundamentais da formação centrada na escola, que se baseia nas experiências dos professores, consiste em criar situações que ofereçam condições aos docentes de aprender a pensar e a agir de modo diferente. De acordo com o autor, a reflexão permite transformar a experiência em um saber utilizável.

As proposições da formação em serviço baseada na perspectiva crítico-reflexiva, em convergência com a concepção de formação centrada na escola, oferecem possibilidades de ressignificação das ATPC. 
O referencial, evidentemente, não prevê modelos de formação a serem aplicados nas escolas, mas pode inspirar professores e formadores de professores dispostos a assumir o HTPC como momento de formação compartilhada e de formalização da experiência, o que exige admitir, inclusive, que a escola, anteriormente pensada como o lugar onde os alunos aprendem e onde os professores ensinam, é também o lugar onde os professores aprendem (CUNHA e PRADO, 2010, p. 109).

Instituídas após longo processo de reivindicações dos docentes por melhores condições de trabalho e regulamentadas pelos artigos 12 e 13 da Lei Complementar 836 de 30 de dezembro de 1997 que dispõe sobre o Plano de Carreira do Quadro do Magistério Paulista, as horas de trabalho pedagógico na escola tornaram-se obrigatórias na rede estadual paulista, devendo ser utilizadas para "reuniões e outras atividades pedagógicas e de estudo, de caráter coletivo, organizadas pelo estabelecimento de ensino, bem como para atendimento a pais de alunos". (SÃO PAULO, 1997). Além disso, a legislação, assim como resoluções posteriores que a regulamentaram, também apontava para a necessidade da equipe gestora utilizar o espaço para organizar as ações de formação continuada com conteúdos voltados às metas da escola e à melhoria do desempenho dos alunos, revelando a necessidade de se compreender a ATPC como um espaço de formação continuada em serviço e centrada na escola.

O curso de formação "Mídias Digitais na Educação de Jovens e Adultos”, objeto de estudo desta pesquisa foi uma ação formativa coordenada por mim, como membro da equipe gestora de um CEEJA, e, portanto, um processo de formação continuada em serviço centrado na escola. A proposta deste curso de formação foi apresentada no início de 2015, quando, em pesquisa promovida pelos coordenadores pedagógicos acerca da visão dos professores sobre a ATPC, ficou constatado que os professores da escola a compreendiam como um importante espaço de formação e que, entre os temas considerados mais urgentes para o ano letivo de 2015, a temática do uso das TDIC destacava-se como uma das maiores urgências.

Para mais, o Documento Orientador número 10, publicado em 2014 pela Coordenadoria de Gestão da Educação Básica (CGEB), da Secretaria Estadual de Educação de São Paulo (SEE-SP), intitulado 'Aula de Trabalho Pedagógico Coletivo (ATPC) em Destaque' elenca algumas orientações às equipes gestoras das escolas na preparação de suas ATPC, considerando-a como um espaço de estudo e de pesquisa. A orientação aponta para a importância de inserção de alguns temas e princípios fundamentais nas ATPC, como a interdisciplinaridade, a contextualização, a transversalidade e as tecnologias digitais da informação e comunicação.

Além dessas discussões apresentadas devem constar das pautas das ATPC da escola as tecnologias digitais da informação e comunicação - TDIC. Estas 
constituem uma parte de um contínuo desenvolvimento de tecnologias, a começar pelo giz e os livros, todos podendo apoiar e enriquecer as aprendizagens. Como qualquer ferramenta, devem ser usadas e adaptadas para servir a fins educacionais e como tecnologia assistiva; desenvolvidas de forma a possibilitar que a interatividade virtual se desenvolva de modo mais intenso, inclusive na produção de diferentes linguagens. Assim, a infraestrutura tecnológica, como apoio pedagógico às atividades escolares, deve também garantir acesso dos estudantes à biblioteca, ao rádio, à televisão, à internet aberta às possibilidades da convergência digital. Essa distância necessita ser superada, mediante aproximação dos recursos tecnológicos de informação e comunicação, estimulando a criação de novos métodos didático-pedagógicos, para que tais recursos e métodos sejam inseridos no cotidiano escolar (SÃO PAULO, 2014).

Neste sentido, parto de três premissas: a) a de que a formação crítica e reflexiva de professores precisa compreender a escola como seu locus privilegiado para que possa efetivamente situar os professores em uma perspectiva autoral; b) a de que as ATPC são espaços importantes para o assentamento de seu papel na formação continuada em serviço; c) e a de que as discussões e formações acerca do uso pedagógico das TDIC são de importância fulcral para mobilizar os docentes para a inovação de suas práticas. Desta forma, é preciso tecer algumas considerações, tendo por base autores deste campo, acerca da formação de professores para o uso pedagógico das TDIC.

\subsection{A formação de professores para o uso educacional das Tecnologias Digitais da Informação e da Comunicação}

A relação entre educação e cibercultura é marcada principalmente pelas novas formas da sociedade lidar com o conhecimento. O ciberespaço exterioriza, amplifica e modifica funções cognitivas humanas, como a imaginação, a memória e o raciocínio. Exterioriza na medida em que o computador e outros dispositivos tecnológicos são capazes de desenvolver funções cognitivas que outrora eram exclusividade da mente humana. Amplifica porque as TDIC e o ciberespaço permitem que o indivíduo acesse mais e mais informações em uma velocidade cada vez maior. E modifica porque oferece a todos novas formas de acesso à informação e novos estilos de raciocínio e de produção de conhecimento (LÉVY, 1999).

Nesta nova relação com o saber, o conhecimento não está mais centrado na figura do professor. "A partir de agora devemos preferir a imagem de espaços de conhecimentos emergentes, abertos, contínuos, em fluxo, não lineares, se organizando de acordo com os objetivos ou contextos, nos quais cada um ocupa uma posição singular e evolutiva" (LÉVY, 1999, p. 158). Esta novidade oferece possibilidade de mudanças no papel do professor, que agora é incentivado a tornar-se um animador da inteligência coletiva de seus alunos em vez de 
um fornecedor direto de conhecimentos. É importante que ele perceba que "seu novo papel já não será o da transmissão de saberes supostamente prontos, mas o de mentores e instigadores ativos de uma nova dinâmica de pesquisa-aprendizagem" (ASSMANN, 2005, p. 14).

Esta concepção vai ao encontro da aprendizagem dialógica na perspectiva de Freire (2001), na medida em que é o diálogo e o incentivo à participação que diferencia a aprendizagem baseada nos princípios instrumental, racional, em que o docente define o que deve e o que não deve ser estudado à aprendizagem derivada da utilização das habilidades comunicativas. No prisma freireano e na ótica de uma formação docente crítico-reflexiva, trata-se de uma pedagogia dialógica que se comunica com os estudantes, que possibilita o estudante situar-se diante da realidade que vivencia, respeitando a diversidade cultural e de ideias.

Freire destaca a dialética relação da educação, como toda e qualquer instância social desenvolvida no seio do sistema capitalista: reproduz o modus vivendi ou o reconstrói, a depender do enfoque que se dê. Ao distinguir a dialética relação de emancipação e subordinação que os seres humanos podem estabelecer com as TIC, de modo a humanizá-los ou a coisificá-los, o estudioso vai à contramão do fetiche a elas auferido. Nesse movimento, ressalta a tensão e o valor relativo deste instrumental à humanização. No movimento de denúncia e superação, Freire situa a linguagem e as relações dialógicas por meio dela estabelecidas, como instrumento capital à constituição dos sujeitos sociais realizadores das circunstâncias históricas que os entornam (PESCE, 2012, p. 130).

Há, contudo, a necessidade de pensar em um novo movimento pedagógico, em que o docente se propõe a "se reconhecer como aprendente e que, ao interagir com o aluno, envolve-se e o convida a envolver-se em um complexo processo de criação de fins imprevisíveis" (LOPES, 2005, p. 51). Neste sentido, Coll e Monereo (2010) acreditam que a imagem de um professor transmissor de informação, protagonista central das trocas entre seus alunos e guardião do currículo começa a entrar em crise com o avanço das redes digitais.

Se o papel do professor muda, as escolas e universidades também deveriam se adaptar ao novo contexto, pois, de acordo com Lévy (1999), elas já perderam o monopólio da criação e da produção do conhecimento. As escolas e universidades devem agora orientar os percursos individuais e coletivos de seus alunos na busca pelo saber e contribuir para o reconhecimento também dos saberes não acadêmicos, produzidos colaborativamente. O saber tornou-se intotalizável e indomável, o que gera um sentimento de desorientação no campo da educação. Desta forma, ou as instituições de ensino se adequam a isso ou se tornarão ainda mais obsoletas. "A escola não pode dar-se ao luxo de ignorar o papel cada vez mais 
significativo que a mídia digital passou a desempenhar na vida da maioria dos jovens" (BICKINGHAM, 2010, p. 53).

As transformações, no entanto, devem ir além do papel do professor e infringir também sobre a cultura escolar e sua relação com a sociedade imersa na cultura digital. "Além dos educadores, é preciso criar condições para que a escola como um todo tome parte da cultura digital e, portanto, se articule com a comunidade global, que se estrutura, dentre outros componentes, por meio das TDIC e mídias digitais" (ALMEIDA e SILVA, 2011, p. 6).

Segundo Porto (2006), o maior desafio da escola está em trazer as TDIC para seu cotidiano articulando-as com os conhecimentos escolares. De modo geral, alunos lidam cotidianamente com tecnologia e com o ciberespaço, mas seria uma novidade atraente usá-las na escola, pois há um amplo leque de saberes que precisam ser trabalhados em uma perspectiva comunicacional que a tecnologia proporciona. A autora propõe o uso da tecnologia como uma alavanca para reflexão na sala de aula, como um dos elementos desencadeadores de percepção e como mediadores de processos comunicacionais. Essa mudança de postura vai além do uso de tecnologias. "As escolas promovem situações de vivências, transitando para além dos seus muros, integrando as tecnologias aos conhecimentos do senso comum e aos conhecimentos tradicionais" (PORTO, 2006, p. 49). Entretanto, é preciso também que o uso pedagógico das TDIC, seja na educação de pessoas adultas, seja na educação de crianças e adolescentes, possa ser pensado na perspectiva da inclusão digital, que será tratada em capítulo adiante.

A escola precisa, por conseguinte, aproveitar esse momento de inovações tecnológicas e modernizar suas práticas e propostas de ensino-aprendizagem, tanto na forma quanto no conteúdo, atendendo às novas necessidades impostas pelo mundo dinâmico e globalizado (AMARAL e AMARAL, 2008, p. 12).

O potencial educacional das TDIC está associado, segundo Porto (2006), à rapidez na busca por informação, na mudança de linguagem, na recepção individualizada, que permite um atendimento específico, de acordo com a subjetividade dos alunos, além da interatividade, hipertextualidade $^{11}$, realidade virtual e as possibilidades da digitalização.

De acordo com Pretto e Assis (2008), o desenvolvimento das TDIC provocaram transformações radicais da forma de produzir conhecimentos, conceitos, valores e saberes.

\footnotetext{
11 “O prefixo hiper, na palavra hipertexto, refere-se à capacidade do texto para armazenar informações que se fragmentam em uma multiplicidade de partes dispostas em uma estrutura reticular. Através das ações associativas e interativas do receptor, essas partes vão se juntando, transmutando-se em versões virtuais que são possíveis devido à estrutura de caráter não sequencial e multidimensional do hipertexto" (SANTAELLA, 2014, p.209).
} 
Todos os aspectos da ação humana, em maior ou menor escala, são atingidos pela cibercultura. "A cultura digital é um espaço livre de vivência dessas novas formas de relação social no espaço planetário" (PRETTO e ASSIS, 2008, p.79). No campo da educação a tecnologia digital também é transformadora. Ela é elemento fundante da nova relação que a sociedade estabelece com a comunicação e com o saber.

A articulação entre cultura digital e educação se concretiza a partir das possibilidades de organização em rede, com apropriação criativa dos meios tecnológicos de produção de informação, acompanhado de um forte repensar dos valores, práticas e modos de ser, pensar e agir da sociedade, o que implica na possibilidade de transformação social (PRETTO e ASSIS, 2008, p. 82).

As mídias digitais, portanto, são ferramentas que exigem a mudança de postura de educadores. Segundo Aquino e Bezerra (2011), os professores e pesquisadores precisam se lançar diante da tecnologia para elaborar propostas de como usá-la adequadamente na prática pedagógica. É a partir do trinômio educação-tecnologia-cultura que a educação do século XXI se constrói.

Em se tratando das tecnologias da informação e comunicação, é mister que a escola tente transpor o discurso da novidade/modernidade, peculiar ao senso comum, e volte-se para uma compreensão teórico metodológica crítica do tema, que lhe permita elaborar e desenvolver práticas educativas que integrem os diferentes recursos tecnológicos disponíveis (AQUINO e BEZERRA, 2011, p. 850).

Criada para os séculos XIX e XX, a escola já não se adequa mais ao modo de viver de uma sociedade cada vez mais imersa na cibercultura. A escola uniformizadora, homogeneizadora e normalizadora vem sendo questionada por estes autores, pois desdenha das capacidades que a tecnologia educacional visa ressaltar: criatividade, autonomia, prazer na aprendizagem, proatividade e colaboração.

As salas de aula de hoje seriam facilmente reconhecidas pelos próprios pioneiros da educação pública do século XIX: as formas de ensino e aprendizagem são organizadas de modo similar, os tipos de habilidade e conhecimento levado em conta na avaliação e até mesmo boa parte dos conteúdos curriculares mudaram apenas de forma superficial desde aqueles tempos (BUCKINGHAM, 2010, p.44).

A partir deste olhar, pesquisadores e educadores devem se dedicar em não perder de vista a criticidade em relação às transformações sociais advindas destas novas relações. É preciso ter clareza de que as tecnologias não são neutras. Reconhecer que, ao longo da história, os avanços tecnológicos por diversas vezes representaram instrumentos de dominação de classe é fundamental para que se faça um estudo crítico do tema. "As 
tecnologias também determinam as relações de poder e os limites de ação e de construção do ser social em cada momento" (KENSKI, 2003, p. 91). Elas podem significar dominação e emancipação. Podem representar o consumo desenfreado e os instrumentos para o processo excludente de globalização, ao mesmo tempo em que podem ser entendidas como espaço aberto ao exercício da cidadania e de lutas sociais.

Na educação, as TDIC podem ser incorporadas a partir de dois caminhos. O primeiro deles é a formatação de novos consumidores acríticos de informações e produtos da indústria tecnológica. Esta perspectiva vislumbra apenas o uso instrumental da tecnologia, atendendo à reprodução da lógica de mercado. O segundo, de acordo com Oliveira (2013) e Kenski (2003), pressupõe que as TDIC podem promover a emancipação dos sujeitos e da coletividade. É na ambiguidade desta relação que estaria o trabalho crítico do professor com formação adequada para o trabalho pedagógico no contexto da cultura digital. Isto significa dizer que as TDIC podem, ao mesmo tempo, servir aos interesses do capital em reproduzir mão de obra barata, reduzir os custos da educação e elevar as taxas de lucro - por meio da expansão da educação à distância, por exemplo - e expandir o consumo em massa, ao mesmo tempo em que podem contribuir para a emancipação de classe, na medida em que democratizam o acesso à informação e ao conhecimento e abrem espaço para uma educação inovadora e democrática.

A educação nesse momento pode, portanto, cooptar para abraçar as novas tecnologias, caminho natural para estar de acordo com os valores e padrões estabelecidos pela nova ordem internacional ou entender as novas tecnologias como espaço de luta e transformação (KENSKI, 2003, p. 96).

É clara nesta discussão a centralidade que a superação da racionalidade instrumental vem adquirindo. A formação de professores não pode estar unicamente associada ao treinamento para o uso das mídias digitais. "É grande a tentação de enveredar para uma planificação rígida ou por uma tecnologização do ensino" (NÓVOA, 1999, p.18). Este processo pode reduzir o professor a um papel secundário, na medida em que a tecnologia e materiais didáticos produzidos por especialistas ganham centralidade. Barreto (2002) tece suas críticas a este processo, ao afirmar que

[...] as mudanças promovidas na formação de professores assumem pressupostos inextricavelmente ligados ao esvaziamento de habilidades e competências consensuais, desejáveis em curto prazo, e o de que a utilização das tecnologias da informação e da comunicação possa dar conta, de modo muito econômico e eficaz, do desenvolvimento dessas habilidades e competências. Há 'tarefeiros' inscritos na nova proposta de formação e uma 
aposta cada vez maior nas tecnologias que irão formá-los (BARRETO, 2002, p.138).

Belloni (1998) faz considerações pertinentes acerca do discurso comum de que o uso educacional das tecnologias impacta somente na economia de orçamento.

Do ponto de vista do macroplanejamento, é ilusório pensar que se fará economia de orçamento com o uso de tecnologias ou com o ensino a distância. Ao contrário do que se tem muitas vezes ouvido autoridades do setor declararem, a integração das novas tecnologias à educação não significará economia de custos: o professor terá que ser valorizado e sua formação inicial e continuada terá que ser repensada, além dos investimentos em equipamentos, é claro. Mas certamente o investimento em formação de professores com tecnologias resultará em aumento de produtividade dos sistemas e, portanto, a médio e longo prazo significará maior rentabilidade, evitando não só o desperdício com o fracasso escolar, como as frustrações decorrentes dele e da inadequação às demandas sociais (BELLONI, 1998, p. 246).

Há, portanto, a percepção de que a formação de professores para o uso educacional das TDIC pode colaborar efetivamente para melhoria da qualidade da educação pública, na medida em que democratiza o acesso ao conhecimento, permite práticas colaborativas e oferece novas possibilidades para o processo de ensino-aprendizagem (BRITO, 2006).

Para formar futuros professores para o trabalho com nativos digitais ${ }^{12}$ faz-se necessário enfrentar a responsabilidade de uma constante atualização, a defasagem entre o seu letramento digital e o do aluno, e manter o distanciamento possibilitador de um olhar crítico diante do que a tecnologia digital oferece (FREITAS, 2010, p. 349).

O uso pedagógico das TDIC, quando descolado da racionalidade técnica e instrumental (ADORNO e HORKHEIMER, 1985), implica principalmente o aumento da produtividade do professor com o objetivo de melhorar qualitativamente seu exercício e combater o fracasso escolar. É preciso ressaltar, no entanto, que se esta formação for concebida a partir de uma perspectiva acrítica, servirá somente para legitimar o consumo desenfreado de produtos tecnológicos e atender aos interesses do capital.

Além disso, a racionalidade instrumental, inserida no contexto das reformas educacionais da década de 1990, também modificou perversamente a maneira de conceber a formação docente. "A pujança de expressões, como 'competências e habilidades', nos

\footnotetext{
${ }^{12}$ Segundo Prensky (2001) são nativos digitais os jovens e crianças que já nasceram em um ambiente mediado por novas tecnologias e reconhecem facilmente seu caráter intuitivo. Os imigrantes digitais, por outro lado, são aqueles que nasceram antes do surgimento da internet e do mundo digital e teriam dificuldades em reconhecer este caráter, em lidar com a velocidade e com a virtualidade do ciberespaço. Prensky (2012) revê esses conceitos de nativos e imigrantes digitais em um artigo posterior Homo sapiens digital: dos imigrantes e nativos digitais à sabedoria digital. Neste texto, cria o conceito de Homo Sapiens digital: aquele que aceita a tecnologia digital como parte integrante da existência humana, independentemente de sua geração.
} 
parâmetros e nas diretrizes curriculares dos distintos níveis de educação brasileira, demonstra como a racionalidade instrumental tem permeado tais documentos legais" (PESCE, 2014, p. 161). No que se refere à formação docente para o uso educacional das TDIC, que também passa a ser inserida nos documentos oficiais e programas de formação a partir desta década, Pesce (2014), pautada pelo princípio da formação de qualidade social (CONAE, 2010), lança vista para

A formação docente voltada ao uso pedagógico das TIC que se erga em meio ao princípio da formação de qualidade social, por diferir significativamente da racionalidade instrumental, que visa ao treinamento do trabalhador para atuar nos atuais processos de produção capitalista, vai de encontro à fetichização da técnica ${ }^{13}$ (PESCE, 2014, p. 162).

É pertinente que a abordagem crítico-reflexiva da formação de professores também abarque a formação para o uso educacional das TDIC, na medida em que se objetiva uma educação transformadora e comprometida com a democracia.

A incorporação das TIC pode compreender muito mais do que um formato novo ou uma maquiagem mais atraente para os 'mesmos conteúdos'. Para tanto, é preciso investir nos cursos de formação de professores, redimensioná-los, sem deslocar os sujeitos dessa condição. Formar professores que se apropriem das TIC, em lugar de consumidores de mercadorias postas cada vez mais baratas, acessíveis e de manuseio mais simples. Professores que sejam formados no/pelo trabalho com as TIC, e não monitorados por elas. E que, portanto, não lhes atribuam o estatuto de meros instrumentos para quaisquer finalidades (BARRETO, 2002, p. 117).

"Uma das maiores ameaças aos professores é o desenvolvimento crescente de ideologias instrumentais que enfatizam uma abordagem tecnocrática para a preparação dos professores e também para a pedagogia de sala de aula.” (GIROUX, 1997, p.158). Esta postura crítica é fundamental para que, do ponto de vista político, os professores tenham condições de se apropriar da cibercultura, das mídias e das tecnologias digitais, compreendendo-as como possibilidades de produção e compartilhamento de conhecimento e informação com o objetivo de situá-los em uma perspectiva autoral.

Sem dúvida, as tecnologias podem ser novos e muito úteis meios de construir e difundir conhecimentos sem risco de desumanizar o ser humano. Tudo depende do modo como as utilizamos: se nos apropriamos de seu potencial pedagógico e comunicacional e as colocamos a serviço do homem ou se, ao contrário, nos deixamos dominar por elas, transformando-nos em consumidores de gadgets concebidos para um mercado de massa planetário (BELLONI, 1998, p. 255)

\footnotetext{
13 "Fetichismo da técnica" consiste em uma idolatria por coisas, máquinas, em si mesmas. Ele cria uma relação do homem com ela que contém algo de "exagerado, irracional, patogênico" (ADORNO, 1995).
} 
Almeida e Silva (2011) destacam que as TDIC, ao serem incorporadas na formação e nas práticas docentes, reconfiguram o currículo.

A problemática da integração das TDIC na educação precisa levar em conta a formação de professores em articulação com o trabalho pedagógico e com o currículo, que é reconfigurado no ato pedagógico pelos modos de representação e produção de conhecimentos propiciados pelas TDIC. Evidencia-se assim a constituição de um currículo que é reconstruído por meio da web e demais propriedades inerentes às TDIC, o que denominamos de web currículo (ALMEIDA e SILVA, 2011, p. 8).

Por fim, é possível extrair uma importante questão deste debate, que vem a compor os objetivos específicos deste trabalho: quais os limites e possibilidades da formação continuada em serviço de professores da EJA para o uso pedagógico das TDIC? Para caminhar em busca de respostas, é preciso traçar algumas considerações acerca da formação de professores para atuar na EJA, na medida em que esta intersecção entre as pesquisas sobre TDIC, formação de professores e educação de jovens e adultos demanda o levantamento de bases teóricas nos três campos.

\subsection{A formação de professores para a educação de jovens e adultos}

Em capítulo adiante, serão compilados os principais aportes teóricos da educação de jovens e adultos que embasam esta pesquisa. Entretanto, ao tratar-se da formação de professores para o uso educacional das TDIC especificamente junto a professores de um CEEJA, é preciso levar em conta as especificidades da formação de professores da EJA. A EJA ainda é "um campo educativo de pouco prestígio e baixo grau de formalização" (DI PIERRO 2005a, p. 18), o que implica uma série de entraves históricos para seu desenvolvimento com qualidade. Já a formação de professores da EJA é um campo pedagógico em construção e sua constituição "implicaria a existência de um conjunto de práticas e saberes minimamente articulados em torno de princípios, objetivos ou outros elementos comuns" (RIBEIRO, 1999, p. 185).

Considerando que este trabalho estabelece considerações acerca da formação de professores para o uso educacional das TDIC, a partir de uma perspectiva crítica-reflexiva, é preciso também fazê-lo no campo da EJA. A importância de estabelecer esta interlocução emana da própria constituição da EJA como campo pedagógico e, por conseguinte, como campo de pesquisa científica. "A formação do educador da EJA pode contribuir para o fortalecimento e a (re)configuração desse campo e, consequentemente, para o melhor 
atendimento a parcelas significativas da população que foram precocemente excluídas das ações de escolarização" (SOARES, 2008, p. 83).

Ao longo da história da educação de jovens e adultos no Brasil, o improviso de professores sempre foi bastante marcante, na medida em que a maioria dos docentes da EJA não possui habilitação ou qualificação específica para atuar na modalidade (DI PIERRO e HADDAD, 2000). As principais implicações negativas deste improviso é o fato dos docentes não levarem em conta as características específicas do aluno adulto em processo de escolarização, fazendo uso de estratégias descontextualizadas.

Sem a devida qualificação, os professores passam a desenvolver a prática pedagógica ignorando as especificidades e peculiaridades dos sujeitos em processo de escolarização. Utilizam metodologias (técnicas, recursos e atividades) sem qualquer significado para os alunos-trabalhadores, desconsiderando o contexto e a historicidade desses sujeitos (MOURA, 2009, p. 46).

A falta de formação específica dos educadores da EJA é um grande entrave para esta modalidade, pois resulta "numa transposição inadequada do modelo de escola consagrado no ensino fundamental de crianças e adolescentes" (RIBEIRO, 1999, p.185). Soares (2008), Di Pierro (2010b) e Campero (2015) também consideram a profissionalização dos educadores da EJA um fator fundamental para sua constituição enquanto campo em grande parte da América Latina:

En muchos países de la región Latinoamericana la professionalización de las educadoras e educadores de personas jóvenes e adultas es uno de los principales desafios para avanzar em el derecho a la educación com calidad, y es también um derecho de ellos y ellas, por lo que el Estado tiene la obrigación de brundarles oportunidades para su desarrollo professional (CAMPERO, 2015 p.1) $)^{14}$.

Para Campero (2015), a formação é um componente chave da construção da identidade e profissionalização docente, um direito dos educadores a ser assegurado pelo Estado e componente do direito das pessoas jovens e adultas a uma educação de qualidade. Trata-se de um conjunto de processos sistemáticos que permitem aos educadores terem acesso a conhecimentos teóricos e metodológicos, ferramentas e valores sobre educação de jovens e adultos, visando favorecer a reflexão e a análise da prática educativa cotidiana. Sua concepção foca nos sujeitos articulados em redes, e se apoia no diálogo, no trabalho em grupo, no

\footnotetext{
${ }^{14}$ Em muitos países da América Latina a profissionalização dos educadores e educadoras de jovens e adultos é um dos principais desafios para avançar no direito de educação com qualidade, e também direito deles e delas, de modo que o Estado tem a obrigação de garantir oportunidades de desenvolvimento profissional. (Tradução Livre)
} 
intercâmbio de experiências e na reflexão sobre as práticas, através de um enfoque socioeducativo que integra dimensões de desenvolvimento e transformação social a aspectos propriamente educativos.

Di Pierro (2010b) observa um círculo vicioso que se constitui na relação entre o desprestígio social da educação de jovens e adultos e a ausência de formação de educadores:

Observa-se a conformação de um círculo vicioso: a posição desvantajosa
ocupada pela EPJA ${ }^{15}$ na agenda das políticas educativas e o desprestígio
social da modalidade fazem com que o mercado de trabalho seja pouco
atrativo para os profissionais do ensino, esvaziando a demanda por formação
específica; como a demanda é pequena, é raro que a formação pedagógica
em cursos em nível superior ofereça opção de habilitação específica para sua
modalidade educativa, ou até mesmo que contemple em seu currículo
conteúdos referidos a esse ciclo de vida e suas necessidades de
aprendizagem (DI PIERRO, 2010b, p. 168).

Segundo estatísticas do Censo Escolar realizado pelo MEC no ano de 2014 (BRASIL, 2014), há cerca de 250 mil docentes atuando na EJA, dos quais 66,8\% são mulheres. Deste total, 83,8\% dos docentes atuam nos meios urbanos e a maior parte (54\%) atua nas redes estaduais de ensino. No que se refere à formação, a pesquisa aponta que 83,5\% possui formação superior, sendo $75,8 \%$ composto por professores licenciados, isto é, a maioria dos professores da EJA atua conforme a formação exigida por lei.

Ainda são poucos os estudos acerca do perfil social e identidade profissional dos educadores de jovens e adultos no Brasil, segundo Di Pierro (2010b). De acordo com a autora, os perfis destes educadores diferem-se em alguns pontos e assemelham-se em outros. As motivações para atuar no campo da educação de jovens e adultos, por exemplo, são de origens muito diversas, pois podem ser de ordem religiosa, política, assistencial, educativa, ou outra. A mesma diversidade existe na constituição dos estatutos profissionais destes agentes, que podem variar desde trabalhadores voluntários até docentes licenciados e concursados. Entretanto, de modo geral, Di Pierro (2010b) define as condições de trabalho adversas um ponto em comum entre esses sujeitos: vínculos profissionais instáveis, ambientes de trabalho precários, baixa remuneração, escassa valorização social e, principalmente, as raras oportunidades de formação específica, seja ela inicial ou continuada, no campo da EJA.

O Marco de Ação de Belém ${ }^{16}$, documento elaborado em 2009 como resultado da VI Conferencia Internacional de Educação de $\operatorname{Adultos}^{17}$ (CONFINTEA VI) reconhece a

\footnotetext{
${ }^{15}$ Di Pierro (2010b) faz uso do termo Educação de Pessoas Jovens e Adultas (EPJA).

${ }^{16} \mathrm{O}$ Marco de Ação de Belém constitui peça fundamental no longo processo de mobilização e preparação nacional e internacional, que teve início em 2007 e culminou na sua aprovação no último dia da Sexta
} 
insuficiência de ações e políticas de formação de professores da EJA. O documento assinala a necessidade de "melhorar a formação, a capacitação, as condições de emprego e a profissionalização dos educadores de adultos, por exemplo, por meio do estabelecimento de parcerias com instituições de ensino superior, associações de professores e organizações da sociedade civil” (UNESCO, 2010, p. 13).

As ações das universidades, no entanto, ainda são bastante tímidas, no que se refere à formação de educadores de jovens e adultos. É preciso ampliar os espaços da EJA nas universidades, tanto como espaços de debates educacionais ligados ao tema, quanto como potenciais espaços de formação de educadores. A formação do educador da EJA, da maneira como é feita hoje, normalmente oferecida por treinamentos e cursos aligeirados, é insuficiente para atender a demanda da educação de jovens e adultos (SOARES, 2008).

Moura (2009) afirma que as instituições formadoras e as instituições mantenedoras da modalidade consentem um quase completo silêncio em relação à formação inicial e continuada de docentes da EJA. Nas instituições de ensino superior, com raras exceções, não há preocupação com a formação de professores para EJA. Sobre este silêncio permitido, a autora constata que

[...] a formação de educadores e alfabetizadores de jovens e adultos, mesmo com toda ênfase que vem sendo dada a área, em termos de discussões e reivindicações, em nível nacional e internacional, continua no ostracismo, como se ensinar a esses sujeitos fosse a mesma coisa que trabalhar com crianças (MOURA, 2009, p.63).

Laffin e Gaya (2013), ao desenvolverem um estudo do estado da arte das pesquisas no campo da formação inicial docente para educação de jovens e adultos, com base nas pesquisas concluídas entre 2000 e 2011, também apontam para a ausência da oferta de formação inicial em instituições de ensino superior no âmbito das licenciaturas. O silêncio e o vazio institucional na formação inicial de professores para essa modalidade também não é adequadamente compensada nas ações de formação continuada, que ressentem de uma base teórica sólida (MOURA, 2009). Além da formação continuada ter adquirido muito mais um caráter de suprimento das lacunas da formação acadêmica inicial, as ações deste tipo são assimétricas, "consistindo no mais das vezes em cursos esporádicos e ciclos de conferências pontuais precariamente articulados às práticas docentes cotidianas" (DI PIERRO, 2010b, p. 171).

Conferência Internacional de Educação de Adultos - CONFINTEA VI, ocorrida em Belém, em dezembro de 2009. 
De acordo com Ribeiro (1999) e Moura (2009), a principal explicação para o descaso em relação à formação de educadores da EJA está relacionada à visão assistencialista que historicamente se construiu sobre a educação de jovens e adultos. Esta assimilação da educação como ação filantrópica sustenta as representações que descambam para a infantilização do aluno adulto.

Sem dúvida, a perspectiva assistencialista e infantilizadora da educação de jovens e adultos é um fator que prejudica a constituição do campo, limitando as condições de se ofertar aos educadores uma formação adequada, que considere as especificidades do público dessa modalidade educativa (RIBEIRO, 1999, p. 188-189).

A partir de uma visão mais prospectiva, que reconhece a EJA como um direito do cidadão, é possível pensar em ações de formação de professores desta modalidade que superem este paradigma, na direção de uma educação emancipatória. Segundo Soares (2011), os estudos e pesquisas mais recentes no campo da EJA apontam para uma fase de transição, em que se vê um resgaste da sua importância, especialmente após a inclusão da modalidade nas bases de financiamento do FUNDEB. Sob a perspectiva da EJA como um direito, como se deve pensar uma formação adequada do professor desta modalidade?

Para pensar em respostas, é preciso primeiramente reconhecer que a educação de jovens e adultos possui especificidades. É preciso, neste sentido, construir uma formação de educadores que as leve em conta.

A construção de uma proposta de trabalho que reconheça as especificidades do público da EJA perpassa diversos aspectos como: a diversidade dos sujeitos educandos com características peculiares; a preocupação com a existência de uma infraestrutura que acolha a realidade desse público; a elaboração de propostas curriculares que vá ao encontro das necessidades, das exigências e dos interesses desses sujeitos, incluindo a flexibilidade dos tempos e espaço; a disponibilidade de recursos didáticos que atendam e desenvolvam as potencialidades desses sujeitos; as iniciativas de formação inicial e continuada de educadores; políticas compensatórias de alimentação e transporte que favoreçam a permanência dos educandos (SOARES, 2011, p. 308).

Para Moura (2009)

Os currículos dos cursos Normais e das Licenciaturas precisam contemplar a formação específica desses profissionais de forma que eles tenham acesso a saberes gerais e específicos numa relação teoria-prática que dê conta das peculiaridades socioculturais e pedagógicas dos jovens e adultos trabalhadores (MOURA, 2009, p.64).

Desta forma, é preciso que as pesquisas acadêmicas se mobilizem, no sentido de identificar e organizar esses saberes gerais e específicos necessários aos docentes da EJA. Ao 
institucionalizar as práticas de educação de jovens e adultos e sua consolidação como campo de pesquisa, passa a ser possível o acúmulo de saberes práticos e teóricos "passível de ser organizado como conteúdo da formação inicial dos educadores e fonte para seu aperfeiçoamento profissional por meio da formação contínua” (RIBEIRO, 1999, p.190).

Em análise dos estudos recentes sobre formação de educadores da EJA, produzidos no âmbito da pós-graduação entre 1998 e 2008, Di Pierro (2010b) aponta para a valorização dos saberes docentes construídos na experiência de ensino e aprendizagem e estratégias dialógicas de reflexão e partilha sobre práticas como as principais tendências presentes na literatura sobre formação de professores da EJA, além da necessidade de articulação entre teoria e prática e entre as dimensões política e técnica da prática pedagógica.

Há no âmbito acadêmico poucas pesquisas que procuram elencar os saberes teóricos e práticos necessários à docência com jovens e adultos. Sobre referenciais teóricos, por exemplo, Moura (2009) acredita na importância de incorporar na formação de educadores da EJA saberes da psicogênese da leitura e da escrita, além da teoria histórico-cultural e aporte das ciências da linguagem, principalmente sociolinguística e linguística aplicada. Segundo a autora, estes aportes possibilitarão ao professor a compreensão do ato de escolarizar, permitindo que não mais ignore a complexidade do processo.

Esses conhecimentos permitirão a compreensão das características e especificidades dos alunos nos aspectos antropológico, histórico, filosófico, cultural, psicológico, sociolinguístico. Com essa base é possível entender e colocar, na prática cotidiana, questões e problematizações dos conteúdos das áreas específicas como matemática, linguagem, ciências sociais e naturais criando e desenvolvendo, junto com os alunos, numa perspectiva de mediação, processos metodológicos inovadores que possibilitem aos sujeitos a apropriação das habilidades básicas e essenciais de leitura, escrita e conhecimentos gerais (MOURA, 2009, p.47).

Além do mais, é preciso valorizar os saberes experienciais (TARDIF, 2014) daqueles docentes que atuam na educação escolar de jovens e adultos, assim como aqueles que atuam no âmbito não escolar da educação popular. Vóvio (2010) destacou a importância de considerar o rico patrimônio de saberes acumulados pelos educadores na docência com jovens e adultos. "Esse reconhecimento acerca do conjunto de experiências e trajetórias formativas e do modo como a significam a ação educativa com jovens e adultos constituem-se em ponto de partida para formular programas de formação" (VÓVIO, 2010, p.74).

Arroyo (2006) apresenta uma proposta de formação de educadores da EJA com um caráter político. Em sua concepção, os processos formativos devem se ancorar na formação política e na recorrência de conhecimentos advindos da história da educação de jovens e 
adultos e da sociologia, para que o docente em formação seja capaz de compreender a complexidade desta modalidade, levando em conta sua trajetória ligada aos movimentos sociais, bem como a condição sociocultural e particularidades da condição étnica, racial e social dos sujeitos da EJA. Esses componentes permitiriam ao educador o entendimento da EJA em sua especificidade, tendo por base princípios, métodos e processos praticados e produzidos no passado.

A proposta de Arroyo filia-se a uma concepção de educação engendrada nas práticas emancipatórias cunhadas no campo da educação popular, o que justifica a inclusão de componentes com fortes traços de saberes relacionados à história de lutas e resistência de grupos subalternizados, dos direitos humanos, da própria educação de jovens e adultos, numa perspectiva ampla, bem como dos educadores que nela atuaram e das proposições e práticas empreendidas nessas experiências. Imbricada a essa proposição concentra-se um processo formativo que, segundo o autor, desafia-nos a construir uma teoria pedagógica, com matrizes formadoras que tem como referência a vida juvenil e adulta, tal como o trabalho, os movimentos sociais e a cultura (VÓVIO, 2010, p.71).

A proposta de Ribeiro (1999) estabelece três temas-chave a serem incluídos nas formações iniciais e continuadas dos educadores de jovens e adultos: a) a dimensão política da EJA, que se aproxima e se articula com a proposta de Arroyo (2006); b) a funcionalidade das aprendizagens escolares para os jovens e adultos trabalhadores e a consideração das formas de pensamento que lhes são características, que leva em conta toda discussão sobre o currículo da EJA e sobre as especificidades cognitivas dos sujeitos jovens e adultos; c) a necessidade de processos formativos que habilitem educadores a experimentar formas alternativas para a organização do ensino na EJA, que se articulem com uma ação criativa e propositiva, adequada às finalidades dessa educação.

Sobre a necessidade da incorporação do diálogo como elemento crucial na formação de educadores da EJA, Ribeiro (1999) tece suas considerações:

Somada à consciência crítica sobre as estruturas sociais que geram a desigualdade e sobre o papel da educação na manutenção ou transformação dessas estruturas, a valorização do diálogo como princípio educativo, com a decorrente assimilação da noção de reciprocidade na relação professoraluno, constitui-se pilar importante da formação do educador de jovens e adultos. A disposição para o diálogo é base para procedimentos que são essenciais nessa modalidade educativa: a definição de objetivos compartilhados, a negociação em torno de conteúdos e métodos de ensino e ganho de autonomia dos educandos no controle de seus processos de aprendizagem (RIBEIRO, 1999, p. 193).

Essa leitura é fortemente influenciada pelo arcabouço freireano, pois toma como princípio a relação dialógica entre educador e educando, assumindo como ponto de partida 
para ação pedagógica o respeito pelo conhecimento do sujeito (FREIRE, 2001). Além disso, o paradigma emancipatório e as experiências inovadoras de alfabetização e da EJA compõem também parte do legado da pedagogia humanista e crítica de Paulo Freire e da educação popular.

Ao sistematizar suas propostas, Ribeiro (1999) e Arroyo (2006), alertam para as especificidades da EJA, que precisam ser levadas em conta em qualquer programa de formação de educadores. Contudo, segundo Vóvio (2010), ambos ancoram-se nas suas visões sobre a educação de jovens e adultos e na maneira como cada um concebe as finalidades desta modalidade, mas não nas práticas pedagógicas que de fato ocorrem em programas de EJA. Em crítica, a autora também afirma que as duas propostas "não dialogam com as representações que educadores da EJA produzem sobre a finalidade e a própria ação educativa em que estão envolvidos, sobre os sujeitos e interações que estabelecem com eles, sobre o que consideram relevante abordar em tais processos" (VÓVIO, 2010, p.72). Desta forma, as propostas tampouco estão em diálogo com as identidades profissionais em construção e com os saberes experienciais dos educadores, a partir dos quais "os professores concebem modelos de excelência profissional dentro de sua profissão" (TARDIF, 2014, p.48).

Nessa perspectiva, seria interessante que a pesquisa educacional pudesse aportar mais dados sobre como as práticas de educação de jovens e adultos de fato funcionam, em situações diversas, discutindo elementos que se correlacionam positivamente à alteração de graves quadros de desigualdade de oportunidades de acesso a conhecimentos e bens culturais (VÓVIO, 2010, p. 73).

Di Pierro (2010b) também constata que a formação de professores da EJA ainda é um campo completamente aberto à pesquisa e à teorização, pois o conhecimento produzido sobre o tema é ainda pequeno e incipiente. A pesquisadora aponta três grandes lacunas neste campo que demandam maior esforço acadêmico: a) investigar o perfil e a identidade profissional dos educadores; b) investigar os saberes teóricos e práticos necessários à docência com jovens e adultos, que comporiam o conjunto de conteúdos específicos da formação de educadores da EJA; c) investigar as políticas de formação que, apesar do quase completo silêncio em relação à formação inicial, vem promovendo ações, ainda que esporádicas e aligeiradas, de formação continuada.

A formação continuada em serviço centrada na escola e decorrente da formação voltada para a reflexão sobre a prática do professor, de acordo com autores como Canário (1999), Aquino e Mussi (2001) e Placco (2010), parece ser um caminho viável para a formação de professores da EJA, na medida em que as ações via políticas públicas do Estado são 
incipientes e esporádicas. O curso "Mídias Digitais na Educação de Jovens e Adultos", objeto de análise desta dissertação, teve como foco a necessidade de formar a equipe docente do CEEJA para o uso educacional das TDIC, mas levando em conta as especificidades da formação de professores da EJA. Os saberes teóricos e experienciais dos próprios professores compuseram as discussões e foram fundamentais para a formatação do curso.

A ausência de formação para professores da EJA coincide com a ausência de formação para o uso pedagógico das TDIC. Ambas representam entraves para a garantia plena do direito de acesso à educação de qualidade social (CONAE, 2014) e formação do aluno para o exercício pleno da cidadania. Esta pesquisa parte do pressuposto de que a formação de professores da EJA para o uso pedagógico das TDIC pode contribuir para a inclusão digital de alunos trabalhadores em processo de escolarização e, por conseguinte, para o empoderamento deste grupo social, na acepção freireana.

O próximo capítulo traz a discussão do conceito de inclusão digital e do empoderamento freireano, com o objetivo de refletir acerca das contribuições desses conceitos para o campo da educação de jovens e adultos. 


\section{CAPÍTULO 3 - USO EDUCACIONAL DAS TDIC: DIÁlOGOS SOBRE O EMPODERAMENTO FREIREANO A PARTIR DA INCLUSÃO DIGITAL}

Diante de uma sociedade marcada cada vez mais pelo uso das Tecnologias Digitais da Informação e Comunicação (TDIC), possuir fluência tecnológica é entendido por Pesce (2013a) como requisito para o pleno exercício da cidadania. A produção e compartilhamento de informação e conhecimento, assim como as demais práticas sociais contemporâneas, não são mais viáveis senão pela fluidez da cibercultura, o que demanda políticas públicas de inclusão da população menos favorecida na cultura digital.

Para que os direitos ao acesso e à produção de conhecimento sejam garantidos, é necessário que as políticas públicas voltadas à educação de jovens e adultos sejam pensadas no sentido de oferecer aos sujeitos condições de acesso às TDIC. Conforme discussão apresentada no capítulo anterior, a concepção de tecnologia apresentada por autores como Pinto (2005), Brito (2006), Bonilla (2010), Lavinas e Veiga (2013) e Pesce (2013a) rejeita a representação da tecnologia como instrumento, como produto e não processo. Toda discussão proposta neste capítulo parte do pressuposto de que a tecnologia não é apenas um instrumento do qual os sujeitos se apropriam em busca de qualificação profissional ou do qual a educação se apropria para torná-la nova ferramenta didática. Para Bonilla (2010), “é necessário ultrapassar a ideia de uso das TIC como ferramenta de capacitação para o mercado de trabalho [...] ou então como meras ferramentas didáticas pra continuar ensinando os mesmos conteúdos na escola.” (BONILLA, 2010, p.40).

A criação de novas práticas pedagógicas, como as metodologias ativas, a garantia de condições de infraestrutura para as escolas e a adequada formação de professores são necessidades fundamentais para o que impactado do uso das TDIC na educação possa ser transformador. Afinal, somente as tecnologias, desvinculadas de ações de promoção de um ambiente escolar propício, não garantem sucesso no aprendizado (LAVINAS e VEIGA, 2013). Neste sentido, é fundamental que o professor atribua outros significados às TDIC, que ultrapassem a perspectiva instrumental, contrapondo-se à tendência de tecnicismo, coisificação do saber e do ser humano (BRITO, 2006).

Diante destas colocações, o conceito de inclusão digital apresenta-se como chave para a reflexão sobre o acesso da população economicamente desfavorecida à vivência plena da cibercultura. É preciso garantir que a escola cumpra sua competência de valorizar a crítica dos saberes, valores e práticas da sociedade em que se insere e, portanto, oportunize aos jovens a 
vivência da cibercultura (BONILLA, 2010). Outro pressuposto em que as discussões deste capítulo se assentam, é o de que a escola é entendida como locus primeiro e natural da inclusão digital.

Estudos, como os de Lavinas e Veiga (2013), Bonilla (2010) e Pesce (2013a), sobre políticas públicas e modelos de inclusão digital têm como foco os jovens e as crianças. Os adultos não são entendidos, de modo geral, como sujeitos da inclusão digital nos estudos e nas políticas públicas.

Compreendendo a educação de jovens e adultos como um direito daqueles sujeitos que outrora estiveram excluídos da escola, é preciso refletir criticamente sobre o lugar da inclusão digital na sua formação, com o objetivo de promover a consciência crítica e a sua efetiva conquista da cidadania por meio da fluência tecnológica. Esta discussão oferece também possibilidades de reflexão acerca do conceito de letramento digital, percebido por Pesce (2013a) como uma das instâncias do empoderamento freireano.

Paulo Freire, em diálogo com Ira Shor, no livro "Medo e Ousadia - o cotidiano do professor" (1986) chama de empowerment (empoderamento) o processo que emerge da ação social em que os indivíduos tomam posse de suas vidas, de modo a emancipar-se na relação com outros indivíduos. Esta transformação, que só se constrói por meio de uma educação libertadora, promove nos sujeitos o pensamento crítico em relação à realidade, o que implica favorecer sua capacidade pessoal e social de articulação com outros sujeitos em vistas de transformar as relações sociais e, por conseguinte, as relações de poder (BAQUERO, 2012).

Considerando a necessidade da fluência tecnológica para o exercício da cidadania, a inclusão digital torna-se, na educação de jovens e adultos, peça fundamental para o empoderamento, na acepção freireana do termo, dos sujeitos que retomam seu processo de escolarização, na medida em que confere a eles acesso às novas possibilidades de intervenção em sua realidade pessoal e social.

Este capítulo procura compilar as ideias de diferentes pesquisadores que tratam da inclusão digital e do empoderamento freireano, em busca de um ponto de intersecção entre os dois conceitos, sob a perspectiva das especificidades da educação de jovens e adultos.

Para aprofundar esta discussão e contribuir para a compreensão da importância da formação de professores para uso das TDIC, em uma escola dedicada exclusivamente a pessoas jovens e adultas, este capítulo visa a discutir a temática da exclusão/inclusão digital no Brasil, compreendendo a escola como locus primeiro e natural deste processo. Esta perspectiva tem por base estudos como os de Sorj e Guedes (2005), Silva et al (2005), Buzato 
(2008; 2010), Bonilla (2010), Pesce (2013a; 2013b), entre outros autores que contribuem para valorização das TDIC como instrumento de exercício da cidadania e emancipação.

Pensar o conceito de empoderamento freireano na perspectiva da conquista da autonomia e com vistas à promoção da transformação cultural dos grupos sociais formados por estudantes adultos em processo de retomada de sua escolarização (FREIRE e SHOR, 1986), também perpassa os objetivos do presente capítulo, isto é, empoderar o professor para empoderar o estudante da EJA. Para esta discussão conceitual, as contribuições de Baquero (2012) e Pesce (2013a) são fulcrais.

\title{
3.1 Exclusão e inclusão digital
}

Há uma profusão de sentidos atribuídos ao binômio exclusão/inclusão que os constituem como uma arena de disputa por diferentes significações. Segundo Buzato (2008), a maior parte das interpretações sociais que fazem uso do conceito de inclusão fala do lugar do incluído, isto é, do lugar de quem definiu o que é bom para todos e se mobiliza para oferecer o mesmo aos excluídos. Desta forma, o conceito de inclusão adquire o sentido de hegemonia, um processo de subordinação de valores considerados ideais por um grupo que se coloca em posição superior.

\begin{abstract}
Assim como palavras mais desgastadas como "justiça", "cidadania", "nação", entre outras, "inclusão" é também uma palavra habitada por vozes sociais diversas, uma arena de disputa por sentidos vinculados a forças centralizadoras (conservadoras, estabilizadoras, apontadas para o centro) e descentralizadoras (inovadoras, desestabilizantes, apontadas para a margem) que atuam concomitantemente (BUZATO, 2010, p.284).
\end{abstract}

Buscando posicionar-se nesta disputa, o autor propõe um conceito de inclusão digital a partir de outro sentido, adepto às forças mais descentralizadoras:

Inclusão, então, seria a possibilidade de subversão das relações de poder e
das formas de opressão que se nutrem e se perpetuam por meio da
homogeneização, da padronização, da imposição de necessidades de alguns a
todos e do fechamento dos significados das tecnologias da comunicação e da
informação em função de tais necessidades (BUZATO, 2008, p.326).

Esta visão, que considera a inclusão digital como pressuposto para o exercício pleno da cidadania, com vistas à transformação social e dos sujeitos, também se aproxima do olhar lançado por Silva et al (2005). Os autores constroem em seu estudo o conceito de inclusão digital, a partir da preocupação com a garantia do direito de acesso à informação. Nesta perspectiva, "a inclusão digital deve ser vista sob o ponto de vista ético, sendo considerada como uma ação que promoverá a conquista da 'cidadania digital' e contribuirá para uma 
sociedade mais igualitária, com a perspectiva da inclusão social"' (SILVA et al, 2005, p. 30).

Dias (2011) destaca a importância de discutir o conceito de inclusão a partir de seu oposto: a exclusão. O conceito de exclusão digital é defendido em seu sentido alargado, com o objetivo de superar a prática de incluir, via formação de mercado consumidor de produtos da informática e se encaminhar na perspectiva da conquista da autonomia. Trata-se da denúncia dos processos que impedem a maioria da população de acessar plenamente a cultura digital, ou apenas "a instância mais recente da velha exclusão social e econômica" (TAKAHASHI, 2005, p. 57). As políticas de combate à exclusão devem "evitar o surgimento de novas pendências provocadas pelo consumo de informações e serviços de comunicação concebidos e produzidos em uma época puramente comercial ou imperial” (LÉVY, 1999, p.238).

De forma aproximada, Sorj e Guedes (2005) trabalham o conceito de exclusão digital, sob o foco de sua multiplicidade. De forma crítica, os autores afirmam que, apesar de grande parte da bibliografia da área enfatizar o potencial das TDIC para reduzir a pobreza e a desigualdade, "na prática a dinâmica social funciona em sentido inverso: aumentam a exclusão e a desigualdade sociais" (SORJ e GUEDES, 2005, p. 102). Neste sentido, a universalização do acesso, entendida apenas como parte do processo de inclusão digital, é um instrumento para diminuir os prejuízos sociais do ponto de vista da luta por igualdade e justiça.

Os autores explicam que a introdução de novos produtos tecnológicos no mercado aumenta o patamar abaixo do qual uma pessoa é considerada pobre (SORJ e GUEDES, 2005). O acesso a novos produtos se inicia entre os ricos e só depois se estende aos pobres.

Os ricos são os primeiros a usufruir das vantagens do uso e/ou domínio dos novos produtos no mercado de trabalho, enquanto a falta destes aumenta as desvantagens dos grupos excluídos. Em ambos os casos, os novos produtos TICs aumentam, em princípio, a pobreza e a exclusão digital (SORJ e GUEDES, 2005, p. 102).

A este encontro, Pinto (2005) apresenta uma perspectiva que propõe o rompimento com uma dinâmica, ideologicamente disseminada como universal, em que ao mundo da periferia caberia a condição de "paciente receptor" das inovações técnicas, enquanto o domínio do centro da tecnologia seria para poucos. Ao tratar a técnica como libertadora, o filósofo Álvaro Vieira Pinto aponta para a importância da educação como meio pelo qual o trabalhador adquire consciência e para transformar sua realidade na direção do acesso pleno às técnicas vigentes (BANDEIRA, 2011).

Há uma relação bastante próxima entre os conceitos de exclusão/inclusão digital e 
exclusão/inclusão social, no ponto de vista destes autores. "Não há como optar entre investir em TIC, ou investir em combate à pobreza" (TAKAHASHI, 2005, p. 58). O termo exclusão social não se refere apenas à pobreza, mas à falta de acesso a todos os direitos da cidadania (MARTINS, 2009). Assim, garantir à população excluída o acesso a bens de consumo não significa garantir a ela todos os direitos de cidadania, justiça e dignidade, assim como prover o acesso a produtos e serviços tecnológicos não significa promover uma efetiva inclusão digital.

Neste sentido, a pesquisa de Sorj e Guedes (2005) procura investigar a inclusão digital na periferia do Rio de Janeiro, levando em conta não somente o acesso a computadores e à internet, mas também o tempo e a qualidade deste acesso.

A exclusão digital não se refere a um fenômeno simples, limitado ao universo dos incluídos e excluídos, polaridade real, mas que por vezes mascara seus múltiplos aspectos. A razão é simples: a oposição entre acesso e não acesso é uma generalização razoável quando se trata de serviços públicos ou de bens tradicionais de consumo intermediário. Para aferir a exclusão digital, contudo, o número de proprietários do computador ou de pessoas com acesso à Internet é uma medida primitiva demais, já que vários outros fatores devem ser considerados (SORJ e GUEDES, 2005, p. 103).

O Mapa da Inclusão Digital (2012), produzido pelo Centro de Políticas Sociais da Fundação Getúlio Vargas em parceria com a Fundação Telefônica/Vivo, é um dos poucos estudos quantitativos de larga escala produzidos no Brasil, com objetivo de mapear as diversas formas de acesso à tecnologia digital, sua qualidade, seu uso e seus retornos. O mais relevante da pesquisa é que seus microdados ultrapassam a simples preocupação em captar informações sobre a conectividade e a convergência, através da problematização do "como?" e “onde?” ocorrem os acessos à rede digital. Também são preocupações do documento, medir a qualidade destes acessos, isto é, compreender o "o que?" os sujeitos fazem uso e o "por que?" o fazem. A primeira pergunta refere-se ao conteúdo acessado, enquanto a segunda, a mais fundamental entre elas, refere-se às capacidades associadas às possibilidades de se realizarem diferentes coisas por meio das TDIC.

Comparado a outros países do mundo, o Mapa da Inclusão Digital (2012) posiciona o Brasil na $63^{\mathrm{a}}$ colocação, entre os 155 países do ranking que mede o nível de conectividade domiciliar, o que equivale dizer que $33 \%$ da população brasileira tem acesso à internet em seu domicílio. Este dado, de acordo com o documento, aproxima o Brasil da média mundial e corresponde ao intenso processo de urbanização e elevação do padrão de consumo da população brasileira na última década.

$\mathrm{O}$ documento ainda retrata o acesso às TDIC e à internet, de acordo com a unidade da 
federação e com o município. O estado de São Paulo aparece na segunda posição, com 56,9\% da população com acesso ao computador e 48,22\% da população com acesso domiciliar a internet. O município de Praia Grande, litoral Sul do estado, onde se localiza o Centro Estadual de Educação de Jovens e Adultos, locus desta pesquisa, apresenta um índice de $52,7 \%$ da população com acesso domiciliar ao computador e $43,9 \%$ da população com acesso residencial à internet (MAPA DA INCLUSÃO DIGITAL, 2012).

As desigualdades de acesso às TDIC e à internet são determinadas por uma série de variáveis ligadas à escolaridade, à renda, ao gênero, à atividade profissional, etc. No entanto, o estudo ressalta que a educação é a grande variável que determina a diferença de acesso, mais do que as faixas de renda. "A chance de uma pessoa com pelo menos superior incompleto acessar a rede é 100,8 vezes maior que a de um analfabeto e seis vezes maior do que aqueles com pelo menos ensino médio incompleto" (MAPA DA INCLUSÃO DIGITAL, 2012, p.31).

Ao questionar o principal motivo pelo qual os participantes não acessaram à internet nos últimos três meses, o estudo identificou que 33,14\% da população não achava necessário seu uso, enquanto 31,45\% afirmou não saber utilizá-la e 29,79\% afirmou não possuir acesso ao computador. "Isto significa que quase dois terços das pessoas em idade de uso da rede não o fazem por falta de demanda intrínseca, seja pela falta de interesse ou de conhecimento" (MAPA DA INCLUSÃO DIGITAL, 2012, p.32). Neste sentido, a natureza das políticas de inclusão digital deve estar relacionada à compreensão das possibilidades oferecidas pela internet, ligadas ao exercício pleno da cidadania e à qualificação para o mundo do trabalho, bem como formação para seu uso adequado e crítico. De acordo com a análise feita nas conclusões do texto principal do estudo, talvez a melhor forma de combater o apartheid digital seja investir diretamente no aluno da escola pública, para que possa ele ter acesso desde cedo às novas tecnologias (MAPA DA INCLUSÃO DIGITAL, 2012).

Esta demanda parece ser ainda maior, na medida em que o estudo realiza o cruzamento destas informações com a idade dos sujeitos. Isto porque o motivo declarado pelos mais jovens para não utilizar a internet é a ausência de acesso, enquanto os adultos e idosos alegam não saber utilizar ou não se interessar pelo seu uso (MAPA DA INCLUSÃO DIGITAL, 2012). Em consonância, a pesquisa de Sorj e Guedes (2005) também identifica esta mesma tendência: quanto maior a idade, menor são as chances de uso do computador e da internet. Estes dados evidenciam não só a necessidade de valorizar a escola pública como locus de 
formação crítica para o uso das TDIC, mas também a importância de se edificar a formação de pessoas jovens e adultas para o mundo digital nas salas de aula da EJA.

Ainda que contribua significativamente para a compreensão do quadro da exclusão/inclusão digital no Brasil, é preciso fazer pelo menos uma ressalva acerca dos dados apresentados pelo Mapa da Inclusão Digital (2012). Vale ressaltar que o documento é datado e, na medida em que o desenvolvimento tecnológico e as mudanças nos padrões de consumo são muito velozes, eles podem não mais corresponder integralmente à realidade, especialmente por não levar em conta a expansão do consumo de outros equipamentos de acesso à internet, como tablets e smartphones. O número de pessoas usando smartphones para acessar a internet chegou, segundo dados da pesquisa Mobile Report, realizada pela Nielsen Ibope ${ }^{18}$, a 72,4 milhões no Brasil, no segundo semestre de 2015.

Como forma de combate à exclusão, o estudo defende investimentos em estratégias de (re)distribuição do acesso às TDIC, por meio de centros comunitários e escolas. Assim, o documento identifica a relevância do combate à desigualdade de acesso, a que denomina de brecha digital brasileira, e reconhece nela a possibilidade de combater à exclusão, não só digital como também social.

A brecha digital preocupa não apenas porque a distância de oportunidades e
resultados entre providos e desprovidos de acesso à Tecnologia da
Informação e Comunicação (TIC) tende a aumentar numa época de forte
inovação tecnológica, mas pela oportunidade de diminuir esta mesma
desigualdade através de ações que melhorem a distribuição da quantidade e
da qualidade do acesso digital. Entretanto, existem ainda poucos
diagnósticos empíricos no contexto brasileiro sobre o binômio
exclusão/inclusão digital e políticas associadas à ele. [...] A discussão
raramente é enveredava pelo acesso às tecnologias pelo lado do pobre
usuário, ou do usuário pobre, seja ele empregado, desempregado ou
estudante, seja ele um trabalhador por conta própria. É preciso desenvolver
tecnologias para o uso da tecnologia da informação no combate à pobreza e à
desigualdade (MAPA DA INCLUSÃO DIGITAL, 2012, p.42).

Sob esta perspectiva, outros autores acenam para o reconhecimento da escola como locus primeiro e fundamental da inclusão digital entre os segmentos sociais menos favorecidos. No entanto, a desarticulação entre educação escolar e cultura digital traz a falsa ideia de que os centros públicos de acesso ou os laboratórios de informática das escolas, por si só, promovem a inclusão (SILVEIRA, 2008).

\footnotetext{
${ }^{18}$ O IBOPE Nielsen Online é a unidade de negócios do Grupo IBOPE que realiza pesquisas sobre a utilização da internet no Brasil e América Latina, gerando informações detalhadas sobre os hábitos de navegação dos internautas, a atividade publicitária online e o comportamento das pessoas nas redes sociais, além de entregar estudos customizados com foco no mapeamento de cenários para o meio digital.
} 
A escola, que se constitui como um espaço de desenvolvimento de práticas sociais se encontra envolvida na rede e é desafiada a conviver com as transformações que as tecnologias e mídias digitais provocam na sociedade e na cultura, e que são trazidas para dentro das escolas pelos alunos, costumeiramente pouco orientados sobre a forma de se relacionar educacionalmente com esses artefatos culturais que permeiam suas práticas cotidianas (ALMEIDA e SILVA, 2011, p. 5).

A verdade é que estes espaços são normalmente destinados à realização de atividades escolares, onde uma infinidade de plataformas, sites, redes sociais e outros recursos não podem ser acessados.

Enquanto isso acontece nos espaços de acesso público, os filhos das famílias com melhor poder aquisitivo estão explorando ampla e livremente os ambientes digitais, vivenciando a cultura, a interatividade, a produção colaborativa a partir de seus computadores pessoais, em casa (BONILLA, 2010, p.42).

Neste sentido, é importante pensar no processo de inclusão digital como a vivência plena e autônoma da cultura digital. Para Demo (2005), a exclusão digital da população mais pobre é agravada pela má qualidade da escola pública, na medida em que as escolas públicas, por razões ligadas à infraestrutura, às deficiências na formação dos professores e à própria visão instrumental do uso das TDIC, ficam aquém da promoção da autonomia dos sujeitos perante o avanço tecnológico.

Ao encontro desta concepção, Bonilla (2010) acrescenta que:

$\mathrm{Na}$ maioria das análises não está presente a perspectiva da produção de conteúdos, da colaboração, da autoria e co-autoria dos sujeitos no mundo digital, dimensão que efetivamente pode ser significativa educacionalmente para as comunidades, uma vez que somente se apropriando dessas possibilidades é que os sujeitos sociais poderão efetivamente participar das dinâmicas da web 2.0 (BONILLA, 2010, p.42).

Portanto, a inclusão digital é entendida também como a inclusão da sociedade, no processo de aprendizagem e produção colaborativa de conhecimento. "A aprendizagem em espaços colaborativos pode promover a cidadania ativa, ao permitir a autoexpressão e a participação no discurso público" (OKADA e BUJOKAS, 2012, p.13). Parte daí a necessidade desta análise ser tangenciada também pelas discussões em torno da aprendizagem colaborativa $^{19}$ e pelos Recursos Educacionais Abertos $\left(\mathrm{REA}^{20}\right)$. Isto porque uma concepção

\footnotetext{
19 A aprendizagem colaborativa parte da ideia de que o conhecimento é resultante de um consenso entre membros de uma comunidade de conhecimento, algo que as pessoas constroem conversando, trabalhando juntas direta ou indiretamente e chegando a um acordo (TORRES et al., 2004).

20 "Recursos Educacionais Abertos são materiais de ensino, aprendizado e pesquisa em qualquer suporte ou mídia, que estão sob domínio público, ou estão licenciados de maneira aberta, permitindo que sejam utilizados ou adaptados por terceiros." (UNESCO, 2011, p.6).
} 
de inclusão digital na perspectiva não instrumental, como a proposta por Okada e Bujokas (2012), precisa se propor a romper com algumas amarras da educação tradicional, que centraliza o conhecimento no professor e não permite abrir-se à ideia de rede.

A articulação entre cultura digital e educação se concretiza a partir das possibilidades de organização em rede, com apropriação criativa dos meios tecnológicos de produção de informação, acompanhado de um forte repensar dos valores, práticas e modos de ser, pensar e agir da sociedade, o que implica na possibilidade de transformação social (PRETTO e ASSIS, 2008, p.82).

Nesse sentido, Pesce (2013b), em concordância com Pretto (2012), salienta a importância de que os REA sejam produzidos e utilizados na interface das culturas local e global, de modo a situar alunos e professores não só como consumidores do conhecimento concebido por outrem e veiculado nos REA, mas também como autores em rede, na expressão de Pretto (2010), criando-os, em um movimento de ressignificação de produções já realizadas, para o contexto regional.

De acordo com Mattos e Chagas (2008), é fundamental que haja investimento em infraestrutura, mas não basta que as políticas públicas invistam em bens materiais, como a compra de equipamentos e expansão da banda larga. É preciso, segundo os autores, investir em uma educação básica que possa dotar a população de capacidade cognitiva para compreender e processar informações e símbolos disponibilizados pelo acesso dessas pessoas à cibercultura.

Estando mal preparada a escola, continua falando seu próprio latim, à revelia da realidade digital. O aluno perde a oportunidade de aprender a "ler a realidade" incidindo em outro nível de discriminação digital: embora possa saber lidar com ela, não sabe ler, no sentido de compreender, interpretar, reconstruir. Não sabe pensar os desafios de uma sociedade e economia informacionais (DEMO, 2005, p. 38).

Sorj e Guedes (2005) reiteram o valor de fortalecer os espaços escolares como espaços de inclusão digital, na medida em que a escola deve, em sua essência, ser o lugar da universalização do acesso à informação e ao conhecimento. "O valor efetivo da informação depende da capacidade dos usuários de interpretá-la. [...] Portanto, combater a exclusão digital supõe enfrentar a exclusão escolar" (SORJ e GUEDES, 2005, p. 116).

Silva et al (2005), partindo da perspectiva da ciência da informação, também depositam na educação as maiores expectativas de construção de uma sociedade em que o acesso à informação e ao conhecimento sejam direito garantido. "A educação para informação está, portanto, no cerne de uma nova e desejada sociedade 'incluída', que seja amparada na 
consideração 'cuidadosa' de uma educação que envolva novas e ousadas abordagens relacionadas ao acesso à informação por meio das TICs" (SILVA et al, 2005, p.35).

A escola pública, na visão de Bonilla (2010), é o espaço onde este processo deveria acontecer, mas a autora observa desarticulação entre as políticas públicas de educação e de inclusão digital. As poucas ações para inclusão digital que se articulam com a educação básica, no entanto, contemplam crianças e adolescentes, como, por exemplo, o Programa Um Computador por Aluno ${ }^{21}$ (PROUCA). A educação de jovens e adultos, assim como em tantas outras políticas públicas para a educação básica, não é contemplada por nenhum programa estruturado específico para promoção da inclusão digital.

Entre os sujeitos da EJA, a articulação entre políticas de promoção da inclusão digital e a escola ganha outro fator de relevância: a mínima fluência digital é hoje um fator decisivo na alocação dos jovens e adultos no mundo do trabalho. O estudo de Sorj e Guedes (2005) indica consenso em relação à importância do conhecimento da informática para obtenção de emprego.

A posse do computador, porém, está também associada a um componente
intangível: a disseminação de uma cultura de valorização da informática
associada em especial à noção de que seu domínio é condição de emprego e
sucesso na educação. Em outras palavras, à medida que o sistema produtivo
se informatiza, a noção de que é necessário dominar esse instrumento para
assegurar maiores chances de trabalho se "infiltra" rapidamente entre os
diversos setores sociais, uma vez que seu uso passa a ser visto como
condição para obtenção de trabalho e sucesso escolar (SORJ e GUEDES,
2005, p. 105).

É evidente que, dentro da perspectiva em discussão neste estudo, promover capacitação para o mercado de trabalho não precisa ser o objetivo final das políticas de promoção da inclusão digital e nem das políticas de EJA. Trata-se, na verdade, de romper com a ideia de uso das TDIC como meras ferramentas de trabalho ou como simples ferramentas didáticas. $\mathrm{O}$ que se discute é o quanto suas mais diversas utilidades "contribuem para que os sujeitos se articulem ativamente nas dinâmicas sociais contemporâneas, através das tecnologias, para gerar as transformações necessárias às suas demandas sociais, culturais e políticas" (BONILLA, 2009, p. 184).

Em suma, os autores mobilizados nesta discussão deixam clara a urgência pela inclusão digital como parte importante do processo de transformação social e combate à desigualdade. Isto porque ela é vista como requisito fundamental para o pleno exercício da cidadania. A

\footnotetext{
${ }^{21}$ Iniciativa do Governo Federal para a adoção intensiva de tecnologias da informação e da comunicação nas escolas por meio da distribuição de computadores portáteis aos alunos da rede pública de ensino.
} 
escola pública é compreendida como o espaço em que as ações em benefício da democratização do acesso às TDIC podem ser mais efetivas, desde que as políticas públicas se pautem pela preocupação com a infraestrutura e com a formação de professores para o uso pedagógico das TDIC, em uma perspectiva não instrumental.

A conclusão dos estudos apresentados, que revelam o fato de os sujeitos adultos possuírem menores oportunidades de acesso ao computador e à internet, justifica a necessidade de se buscar compreender a relevância de pensar a inclusão digital e a formação de professores para o uso pedagógico das TDIC em uma escola destinada exclusivamente a estudantes adultos. É preciso que os professores empoderem-se e assumam para suas práticas a inclusão digital, na medida em que a ela se associa a garantia de um direito fundamental, conforme propõe Pinto (2005). Isto posto é relevante também a discussão conceitual sobre o letramento digital que leva ao empoderamento dos sujeitos, na medida em que lhes garante acesso a um direito que instrumentaliza a classe trabalhadora para transformação de suas condições, a partir de suas próprias demandas.

\subsection{Letramento digital e empoderamento freireano}

As políticas públicas de inclusão digital entendem como prioritária a necessidade de promover a alfabetização digital, isto é, garantir o acesso e certa fluência dos sujeitos para o uso das TDIC. O conceito de alfabetização digital, entretanto, é contestado por Buzato (2003), para quem parece mais adequado o conceito de letramento digital, na medida em que pessoas alfabetizadas não são necessariamente letradas. Em sua perspectiva, o alfabetizado é capaz de decifrar códigos, mas não aprendeu a construir uma argumentação, interpretar um gráfico ou encontrar um livro em um catálogo, por exemplo.

Buzato (2003) adota o termo letramento digital, em sentido lato, por entender que esta é a habilidade de se inserir em práticas sociais nas quais a escrita, mediada pelas TDIC, tem um papel significativo e a competência de construir sentido, capacidade para localizar, filtrar e avaliar criticamente informação eletrônica.

Parece haver uma tendência no entendimento de que alfabetização é a simples habilidade de reconhecer símbolos do alfabeto e fazer as relações necessárias para a leitura e a escrita, o que encontra correspondente na alfabetização digital como aprendizagem para o uso da máquina. $\mathrm{O}$ letramento, contudo, é a competência em compreender, assimilar, reelaborar e chegar a um conhecimento que permita uma ação consciente, o que encontra correspondente no letramento digital: saber utilizar as TICs, saber acessar informações por meio delas, compreendê-las, utilizá-las e com isso mudar o estoque cognitivo e a consciência crítica e agir de forma positiva na 
vida pessoal e coletiva (SILVA et al, 2005, p. 33).

Pesce (2013a) entende que o letramento vincula-se diretamente à cidadania e procura, em suas considerações, encontrar os pontos de entrelaçamento entre este conceito e acepção de Paulo Freire do conceito de empoderamento. Segundo ela,

[...] o letramento digital deve integrar os modos de constituição dos atores sociais, já que a utilização da Cibercultura - como mediadora das práticas sociais desenvolvidas no suporte online - tem se apresentado de modo cada vez mais contundente nos modos de ser e de estar dos atores sociais do mundo contemporâneo (PESCE, 2013a, p. 6).

Preocupar-se com o letramento e a inclusão digital de pessoas adultas é também conceber esta modalidade educacional sob a perspectiva da formação ao longo da vida, isto é, a concepção da educação como um direito de todos e em favor da formação de um cidadão crítico, que valorize a participação democrática e a justiça. O impacto da inserção desta camada da população na cibercultura, de acordo com Pesce (2013a), incide sobre os modos de subjetivação e socialização das pessoas e, portanto, em favor do empoderamento freireano.

A inclusão digital, se promovida em seu sentido emancipador, pode ser elemento facilitador da educação libertadora, por oferecer ao socialmente excluído o acesso à cultura digital e suas potencialidades de exercício da cidadania. Neste sentido, ela pode contribuir para aquilo que Paulo Freire chama de empowerment.

A origem do termo empowerment, de acordo com Baquero (2012) tem suas raízes ligadas às transformações provocadas pela Reforma Protestante de Lutero do século XVI, na Europa, movimento que buscava protagonismo na luta por justiça social. A possibilidade de parte da população ter acesso à leitura dos textos bíblicos, após a tradução do latim para as línguas locais, possibilitou empoderar os sujeitos diante de sua própria religiosidade. Neste sentido, a leitura e a escrita sempre estiveram diretamente ligadas às relações de poder, como no contexto dos escribas da civilização egípcia e dos textos bíblicos em latim anteriores às Reformas Protestantes.

A partir da segunda metade do século XX é que o termo é apropriado pelos movimentos sociais de luta contra o sistema de opressão, em favor da libertação da contracultura nos EUA, por exemplo. Desta forma, empowerment passa a ser entendido como sinônimo de emancipação social e se assentar no seio do discurso da luta por direitos civis, do movimento negro, das mulheres, dos homossexuais e das pessoas com deficiência (BAQUERO, 2012).

O conceito de empoderamento ainda carece de uma definição mais acurada. De acordo com Baquero (2012), seu uso é recorrente na literatura sociológica e da ciência política, mas é 
no campo da educação em que a definição conceitual possui melhor formatação. Há, no entanto, convergência no reconhecimento de que o empoderamento pode ocorrer em diferentes níveis: individual, comunitário, organizacional etc. Entre eles, o empoderamento individual é o sentido mais recorrente dado ao termo, inclusive em documentos produzidos pelo Banco Mundial.

Trata-se, desta forma, de um conceito que, assim como a inclusão digital, pode possuir múltiplas significações e se configura como arena de disputa entre forças conservadoras, que focam os processos individuais tendo por base o pensamento liberal, e forças progressistas, que fortalecem processos sociais tendo por fundamento a contestação das relações de poder. A primeira concepção entende que empoderamento "é investir ou dar poder e autoridade a outros, a segunda compreensão envolve tornar os outros capazes, ou auxiliar os outros a desenvolver habilidades para que possam obter poder por seus próprios esforços" (BAQUERO, 2012, p.179).

A acepção freireana do termo empowerment aproxima-se da segunda perspectiva, ultrapassando a conotação de protagonismo ou progresso individual, muito utilizado pelo pensamento individualista liberal norte-americano. Isto porque "do ponto de vista de uma educação crítica, os educadores não podem 'dar poder às pessoas', mas podem torná-las capazes de aumentar suas habilidades e recursos para ganhar poder sobre suas vidas" (BAQUERO, 2012, p.179).

Por exemplo, quando estou contra a posição autoritária, não estou tentando cair naquilo de que falei antes, na posição do laissez-faire. Quando critico a manipulação, não quero cair num falso e inexistente não-direcionamento da educação. Isto é, para mim, a educação é sempre diretiva, sempre. A questão é saber em que direção e com quem ela é diretiva. Esta é a questão. Não acredito na autolibertação. A libertação é um ato social (FREIRE e SHOR, 1986, p.71).

Empowerment configura-se como um processo de tomada de consciência coletiva que se dá na interação entre indivíduos e envolve, em certa medida, um desequilíbrio nas relações de poder na sociedade. Trata-se do empoderamento de classe social. "Não individual, nem comunitário, nem meramente social, mas um conceito de empowerment ligado à classe social" (FREIRE e SHOR, 1986, p. 72). Nesta perspectiva,

[...] o empoderamento, como processo e resultado, pode ser concebido como emergindo de um processo de ação social no qual os indivíduos tomam posse de suas próprias vidas pela interação com outros indivíduos, gerando pensamento crítico em relação à realidade, favorecendo a construção da capacidade pessoal e social e possibilitando a transformação de relações sociais de poder (BAQUERO, 2012, p.181). 
Apesar de defender um conceito de empowerment afinado com a ideia de classe social, Freire não reduz toda sua explicação a esta perspectiva.

A questão do empowerment da classe social envolve a questão de como a classe trabalhadora, através de suas próprias experiências, sua própria construção de cultura, se empenha na obtenção do poder político. Isto faz do empowerment muito mais do que um invento individual ou psicológico. Indica um processo político das classes dominadas que buscam a própria liberdade da dominação, um longo processo histórico de que a educação é uma frente de luta (FREIRE e SHOR, 1986, p.73).

De acordo com Pesce (2013a), Paulo Freire considera que a educação é o caminho para o empoderamento da classe trabalhadora. Ele destaca o "papel fulcral da Educação, para promover práticas sociais contribuintes da construção do capital cultural de grupos, cuja cultura socialmente legitimada ainda não tenha sido incorporada" (PESCE, 2013a, p.5-6).

Neste sentido, toda ação para inclusão digital cujo objetivo seja inserir os sujeitos na cibercultura a fim de emancipá-los e de desequilibrar as relações de poder na sociedade deve ser pensado como um movimento de classe, um movimento libertador. Segundo Freire e Shor (1986), não basta empoderar um aluno ou um grupo de alunos, pois a emancipação pessoal não é suficiente, em uma perspectiva de educação para transformação social.

Enquanto que o empowerment individual ou o empowerment de alguns alunos, ou a sensação de ter mudado, não é suficiente no que diz respeito à transformação da sociedade como um todo, é absolutamente necessário para o processo de transformação social. Está claro? O desenvolvimento crítico desses alunos é fundamental para a transformação radical da sociedade. Sua curiosidade, sua percepção crítica da realidade são fundamentais para a transformação social, mas não são, por si sós, suficientes (FREIRE e SHOR, 1986, p.136).

A inclusão digital, ao servir como acesso às TDIC, tem um papel importante na luta pela conquista da cidadania plena. Isto significa empenho da classe trabalhadora na obtenção do poder político. A aprendizagem promovida pela inclusão digital e pelo letramento digital que dá origem ao empoderamento está relacionada com a transformação mais ampla da sociedade. É preciso avaliar "a favor de quem e contra quem eles usam sua nova liberdade na aprendizagem e como é que essa se relaciona com os outros esforços para transformar a sociedade" (FREIRE e HORTON, 2003, p. 136).

O empoderamento envolve um processo de conscientização, a passagem de um pensamento ingênuo para uma consciência crítica. Mas isso não se dá no vazio, numa posição idealista, segundo a qual a consciência muda dentro de si mesma, através de um jogo de palavras num seminário. A conscientização é um processo de conhecimento que se dá na relação dialética homemmundo, num ato de ação-reflexão, isto é, se dá na práxis (BAQUERO, 2012, p.181). 
O processo de conscientização, na visão freireana, se desenvolve através do diálogo e da educação dialógica que tem por base a pedagogia crítica. Para Freire (2001), o diálogo não se constitui apenas na verbalização de palavras e não tem como objetivo a transferência de conhecimento. Seu sentido é problematizar a forma oficial do conhecimento, questionando as relações dominantes que o produziram. O diálogo, assim, envolve um processo de contestação e redescoberta do conhecimento, a serviço de uma educação para a emancipação.

A educação de jovens e adultos adquire destaque na obra e na trajetória de Paulo Freire, na medida em que seu conceito largo de empoderamento abarca o sentido de classe social e é, portanto, central no processo de transformação da sociedade. Nesta direção, a educação para formação de sujeitos conscientes é um caminho em favor deste processo. "Uma educação para a emancipação, concebida, conforme Freire, como ação cultural para a libertação, pode se constituir em instrumento valioso em projetos e ações direcionados ao empoderamento dos sujeitos" (BAQUERO, 2012, p.184).

A inclusão digital na educação de jovens e adultos, se configurada como ação cultural para libertação, poderá ter um impacto significativo na vida social dos sujeitos adultos reinseridos no espaço escolar. Isto poderá ser viável, no entanto, se for compreendida a partir de uma perspectiva não compensatória, que tenha por base o sentido pleno de educação ao longo da vida. Se dotada desta significação, ela possivelmente permitirá reconhecer os sujeitos adultos como dotados da capacidade de aprender, de se incluir social e digitalmente e, portanto, de se empoderar. 


\section{CAPÍTULO 4 - EDUCAÇÃO DE JOVENS E ADULTOS: DO ENSINO SUPLETIVO COMPENSATÓRIO AO PARADIGMA DA EDUCAÇÃO AO LONGO DA VIDA}

A história da EJA no Brasil é marcada por uma trajetória de abandono, indefinição, improviso e é representativa da própria constituição do país, como portador de uma estrutura social que oferece a sua população oportunidades desiguais (DI PIERRO, 2005a). A lógica da compensação remonta à própria história de formação de uma educação destinada a pessoas adultas no Brasil. Com o objetivo de demarcar o rompimento com a visão compensatória, o presente capítulo procura agregar a este estudo uma discussão teórica sobre a educação de jovens e adultos no Brasil, pautado em uma perspectiva histórica e sociológica.

Primeiramente, o capítulo procura apresentar um quadro histórico da EJA no Brasil, com base em Di Pierro e Haddad (2000). A análise histórica é fundamental para compreensão das marcas de abandono ou improviso que, ao longo do tempo, definem a modalidade. No entanto, é preciso observar que a história da EJA, como toda a história da educação no Brasil, não é linear. Ela é, na verdade, pautada por uma trajetória complexa e difusa. Portanto, é necessário compreender este panorama histórico apenas como uma contextualização da trajetória da EJA no Brasil para, a partir daí, elencar reflexões sobre o ensino supletivo em seu paradigma compensatório.

É preciso, além disso, compreender de que forma as políticas educacionais voltadas à população adulta se constituíram ao longo de nossa história e, desta forma, refletir sobre a conjuntura atual da EJA no Brasil, considerando o perfil de exclusão dos sujeitos a quem a modalidade se destina.

A educação de jovens e adultos - EJA tem sua história muito mais tensa do
que a história da educação básica. Nela se cruzaram e cruzam interesses
menos consensuais do que na educação da infância e da adolescência,
sobretudo quando os jovens e adultos são trabalhadores, pobres, negros,
subempregados, oprimidos, excluídos. (ARROYO, 2005, p. 221)

Em seguida, tomando por base os principais autores do campo da EJA, objetiva-se propor questionamentos sobre as contribuições da inclusão digital para o empoderamento, na acepção freireana do termo, dos grupos sociais inseridos nos espaços escolares da educação de jovens e adultos, traçando reflexões que objetivam definir com mais clareza o perfil dos seus educandos, a discussão entorno do seu currículo e da construção de sua identidade. Para esta reflexão, lança-se um olhar que leve em conta as especificidades do 
aluno da EJA e a compreensão desta modalidade em uma perspectiva não compensatória, no sentido mais largo da educação ao longo da vida. Para isso, faz-se necessário centrar as discussões sobre o campo da EJA, a partir da perspectiva de autores como Alheit e Dausien (2006), Lima (2007), e Torres (2015).

Este capítulo tenciona o paradigma compensatório, que predomina o pensamento e as políticas de EJA no Brasil desde o início de sua trajetória, e o paradigma da educação ao longo da vida, que se fortalece nas últimas décadas. O CEEJA, deste modo, possui uma história marcada por esta tensão. Como se verá adiante, é um projeto que percorre os meandros desta dualidade, pois é marcado pelas duas perspectivas desde sua concepção.

\subsection{A trajetória da EJA no Brasil}

Desde o período colonial as missões religiosas jesuíticas exerciam suas ações educativas junto à população adulta. Não se tratava ainda de uma educação legitimamente brasileira, uma vez que a cultura era predominantemente portuguesa, e nem de uma educação para a população adulta, já que privilegiava a educação das crianças indígenas no processo de catequese. "Além de difundir o evangelho, tais educadores transmitiam normas de comportamento e ensinavam os ofícios necessários ao funcionamento da economia colonial, inicialmente aos indígenas e, posteriormente, aos escravos negros" (DI PIERRO e HADDAD, 2000, p. 109).

Os jesuítas desenvolveram a educação formal escolar no Brasil Colônia, destinada principalmente aos filhos dos portugueses e aos futuros membros da própria Companhia de Jesus em alguns poucos colégios reais localizados em centros urbanos de maior porte (COSTA e MENEZES, 2009). A educação de adultos, desta forma, desde as primeiras experiências de ações educativas em terras brasileiras, se constituiu como uma ação secundária, mesmo que a existência de adultos alfabetizados fosse exceção no Brasil colonial.

Após a expulsão dos jesuítas do Brasil em 1759, a educação da colônia entra em um extenso período de desorganização e abandono. Somente no período imperial é que ocorre uma incipiente organização de uma educação pública no Brasil. Especialmente após a promulgação da primeira Constituição brasileira, que em 1824, sob o entusiasmo iluminista, previa a garantia de instrução primária e gratuita para todos os cidadãos. A iniciativa, no entanto, não passou de uma mera intenção legal, pois pouco efetivamente foi feito neste sentido. "A implantação de uma escola de qualidade para todos avançou lentamente ao longo da nossa história. É verdade, também, que tem sido interpretada como direito apenas de crianças" (DI PIERRO e HADDAD, 2000, p. 109). 
As preocupações liberais-iluministas presentes na Constituição acabaram por não se consubstanciar. A estrutura social vigente prevaleceu, de modo que apenas a população mais abastada assistiu à consolidação de seu direito à educação. A ideia de cidadania restringia-se à elite econômica, excluindo negros, indígenas e grande parte das mulheres. Para Saviani (2008) o período desenrola-se entre as reformas da política pombalina, a partir de 1759, e a criação, já depois da promulgação da Constituição de 1824, da lei geral de ensino em 1827. Uma série de reformas foi empreendida no âmbito educacional, tanto em Portugal com as reformas na Universidade de Coimbra quanto no Brasil com a expulsão dos Jesuítas e a formação das aulas régias como saída adotada para organização escolar do Primeiro e Segundo Reinados.

O período da Primeira República (1889-1930), assim como o anterior, foi marcado pela garantia do direito à educação apenas às elites, em detrimento das camadas sociais mais pobres. A Constituição de 1891, a primeira constituição republicana do Brasil, delegou novamente às províncias a função de gestão da educação. Em uma sociedade em que a maioria da população adulta era iletrada, a Constituição de 1891 estabeleceu também a exclusão doa analfabetos do direito ao voto. Foi um período de muitas reformas educacionais, motivadas por um princípio de normatização e preocupadas com a qualidade do ensino básico, mas, principalmente diante das restrições orçamentárias destinadas à educação, pouco efeito produziram (SAVIANI, 2008).

De acordo com Di Pierro e Haddad (2000), até este momento a preocupação com a educação de jovens e adultos não se distinguia como fonte de um pensamento pedagógico ou de políticas educacionais. Havia uma preocupação geral, principalmente entre os renovadores da educação, com a educação das camadas populares, normalmente interpretada como instrução elementar das crianças. A partir da década de 1920, o movimento de educadores em prol da qualidade e garantia de acesso à educação elementar começou a estabelecer condições favoráveis à educação de jovens e adultos.

Os renovadores da educação passaram a exigir que o Estado se responsabilizasse definitivamente pela oferta desses serviços. Além do mais, os precários índices de escolarização que nosso país mantinha, quando comparados aos de outros países da América Latina ou do resto no mundo, começavam a fazer da educação escolar uma preocupação permanente da população e das autoridades brasileiras. Essa inflexão no pensamento político-pedagógico ao final da Primeira República está associada aos processos de mudança social inerentes ao início da industrialização e à aceleração da urbanização no Brasil (DI PIERO e HADDAD, 2000, p. 110). 
A Revolução de 1930 trouxe para o universo das políticas educacionais um novo sentido de Estado. O fim do federalismo, que prevalecera até então, serviu para reafirmar o papel do Estado-Nação, a partir da Constituição de 1934, e suas responsabilidades com a educação pública. Neste sentido, o Plano Nacional de Educação serviu para definir claramente os papéis dos estados, municípios e união nas políticas públicas educacionais, responsabilizando o setor público pelo desenvolvimento de um sistema educacional brasileiro. Pela primeira vez, a educação de jovens e adultos é especificamente tratada em uma legislação brasileira: a Constituição de 1934 inclui em suas normas o ensino primário integral gratuito, de frequência obrigatória e extensiva à população adulta (DI PIERRO e HADDAD, 2000).

Na década seguinte, desta forma, a educação de jovens e adultos vem a se consolidar como um problema da política nacional. A criação do Fundo Nacional do Ensino Primário, em 1942, que previa distribuição de recursos para a progressiva ampliação da educação primária e incluía o Ensino Supletivo para adolescentes e adultos, representou um marco nas políticas públicas destinadas à EJA. Em 1945 o fundo passa a destinar 25\% dos seus recursos para um plano geral de ensino supletivo destinado a adultos analfabetos (DI PIERRO e HADDAD, 2000).

Durante o Estado Novo, quando o investimento na alfabetização de adultos representava todo um projeto de formação de mão de obra urbano-industrial nos grandes centros do país, a Campanha de Educação de Adultos Analfabetos (CEAA), coordenada pelo recém-criado Serviço de Educação de Adultos (SEA) e por Lourenço Filho e implantada a partir de 1947, já consolidava uma visão centrada na compensação da ausência. $\mathrm{O}$ adulto analfabeto ou pouco escolarizado era entendido como um sujeito incapaz de decidir por si mesmo, nas diversas esferas da vida social. "Projetava-se a imagem da 'criança grande', que de forma deficiente desempenharia suas responsabilidades familiares e profissionais" (FREITAS e BICCAS, 2009, p. 221).

Apesar da perspectiva preconceituosa sobre o adulto analfabeto, a CEAA foi responsável por colocar a educação de jovens e adultos na agenda das políticas educacionais de responsabilidade do Estado e instaurar no país um novo campo de reflexão pedagógica. Além disso, foi responsável por criar toda uma infraestrutura de atendimento à educação de jovens e adultos, posteriormente aproveitada pelas administrações locais (DI PIERRO e HADDAD, 2000). 
É importante situar a mudança de perspectiva do Estado em relação à educação de jovens e adultos nesta década.

Tal ação do Estado pode ser entendida no quadro de expansão dos direitos sociais de cidadania, em resposta à presença de amplas massas populares que se urbanizavam e pressionavam por mais e melhores condições de vida. Os direitos sociais, presentes anteriormente nas propostas liberais, concretizavam-se agora em políticas públicas, até como estratégia de incorporação dessas massas urbanas em mecanismos de sustentação política dos governos nacionais. A extensão das oportunidades educacionais por parte do Estado a um conjunto cada vez maior da população servia como mecanismo de acomodação de tensões que cresciam entre as classes sociais nos meios urbanos nacionais. Atendia também ao fim de prover qualificações mínimas à força de trabalho para o bom desempenho aos projetos nacionais de desenvolvimento propostos pelo governo federal. Agora, mais do que as características de desenvolvimento das potencialidades individuais, e, portanto, como ação de promoção individual, a educação de adultos passava a ser condição necessária para que o Brasil se realizasse como nação desenvolvida (DI PIERRO e HADDAD, 2000, p. $111)$.

No contexto da década de 1950 e início da seguinte, o discurso do desenvolvimento e da constituição de uma sociedade moderna estava vinculado à qualificação do trabalhador para atender às necessidades advindas do progresso. Estes esforços provocaram a queda dos índices de analfabetismo das pessoas acima de cinco anos de idade para 46,7\%, segundo o censo de 1960. Quarenta anos antes, segundo o censo de 1920, este índice era de $72 \%$. As taxas de escolarização, no entanto, permaneceram baixas, o que denuncia um olhar ainda muito voltado para a alfabetização de adultos e pouco preocupado com sua formação escolar mais completa (DI PIERRO e HADDAD, 2000).

Deste cenário advém uma perspectiva renovadora da educação de adultos, que se contrapunha ao discurso hegemônico da época. As ideias de Paulo Freire voltam-se à defesa de ações direcionadas à formação da consciência crítica do cidadão, do ponto de vista individual e coletivo, especialmente a população mais pobre, historicamente excluída do pleno exercício de sua cidadania (FREITAS e BICCAS, 2009). Já no II Congresso Nacional de Educação de Adultos, realizado no Rio de Janeiro, em 1958, percebia-se a necessidade de pensar a EJA como uma modalidade específica de ensino, dotada de especificidades, confrontando velhos preconceitos em relação ao adulto analfabeto (PAIVA, 1973).

De acordo com Flecha (2004), a educação de jovens e adultos, na concepção freireana, está acima de tudo centrada no diálogo, como requisito para uma educação emancipadora. $\mathrm{O}$ autor extrai do pensamento de Paulo Freire sete princípios, segundo os quais a educação de jovens e adultos se assenta: 1) O princípio do diálogo igualitário, que confere horizontalidade 
às ações educativas e valorizam a educação enquanto direito; 2) $\mathrm{O}$ princípio da inteligência cultural, que é a valorização dos saberes a disposição de todos; 3) O princípio da dimensão instrumental da educação, como possibilidade de superação das desigualdades; 4) O princípio da ideia de transformação, que aleija a educação de qualquer concepção determinista e confere capacidade emancipadora ao processo educacional; 5) O princípio da criação de sentido, que é experimentada quando a ação educativa afeta todos os aspectos da vida dos sujeitos; 6) O princípio da igualdade das diferenças, que supõe gerir as diferenças em benefício da igualdade; 7) O princípio da solidariedade, que faz avançar as comunidades no sentido da superação da desigualdade social.

O método Paulo Freire e os projetos de alfabetização executados neste período são marcados por uma nova concepção de educação, baseada no diálogo e em vistas da conscientização e emancipação, e também de uma nova concepção de Homem.

Compreendia o homem como um ser de relações, ontologicamente limitado e ao mesmo tempo aberto para o mundo, e também situado, datado, marcado pela sua 'circunstância', mas capaz de transcender os seus condicionamentos e de interferir criadoramente nessas condições de existência. As possibilidades de interferência do homem definiam-se encontravam limitações no interior de uma realidade histórica-social determinada. Somente a formação e o desenvolvimento de uma consciência capaz de apreender criticamente as características dessa particular realidade possibilitariam a sua ação livre e criadora. Assim, aquela humanização do homem, isto é, a plena realização do homem como criador de cultura e determinador de suas condições de existência passava, necessariamente, pela formação e pelo desenvolvimento da consciência crítica (BEISIEGEL, 1999, p. 895).

Na efervescência das propostas de Paulo Feire, que ganhavam corpo nas mais diferentes experiências de educação popular do início da década de 1960, residia uma educação concebida como "constructo que se estrutura pela própria cultura, mais especificamente pela cultura popular, partindo sempre dos conhecimentos prévios do povo" (FREITAS e BICCAS, 2009, p. 234). Diante de tudo o que o movimento representou, o período de 1959 e 1964 é considerado o período das luzes para a educação de jovens e adultos (RESENDE, 2008).

As ideias renovadoras para a educação de jovens e adultos serviram de sustentação política para as propostas progressistas do período pré-1964.

Foi dentro dessa conjuntura que os diversos trabalhos educacionais com adultos passaram a ganhar presença e importância. Buscava-se, por meio deles, apoio político junto aos grupos populares. As diversas propostas ideológicas, principalmente a do nacional-desenvolvimentismo, a do pensamento renovador cristão e a do Partido Comunista, acabaram por ser pano de fundo de uma nova forma de pensar a educação de adultos. Elevada agora à condição de educação política, através da prática educativa de 
refletir o social, a educação de adultos ia além das preocupações existentes com os aspectos pedagógicos do processo ensino-aprendizagem (DI PIERRO e HADDAD, 2000, p. 113).

Nesta conjuntura são empregadas diversas campanhas destinadas à alfabetização e escolarização de adultos, a maior parte delas com forte influência freireana, como o Movimento de Educação de Base, da Conferência Nacional dos Bispos do Brasil, estabelecido em 1961; o Movimento de Cultura Popular do Recife, a partir de 1961; os Centros Populares de Cultura, órgãos culturais da UNE; a Campanha "De Pé no Chão Também se Aprende a Ler", da Secretaria Municipal de Educação de Natal; o Movimento de Cultura Popular do Recife; e, finalmente, em 1964, o Programa Nacional de Alfabetização do Ministério da Educação e Cultura. A essas ações agregava-se uma "forte missão de resgate e valorização do saber popular, tornando a educação de adultos o motor de um movimento amplo de valorização da cultura popular" (DI PIERRO e HADDAD, 2000, p. 113).

Este projeto, no entanto, sofre uma profunda ruptura com o Golpe Militar de 1964, que resulta na repressão e desmantelamento dos programas de educação popular e no retrocesso radical da concepção progressista para a qual a educação de adultos encaminhava-se. Durante o Regime Militar, a educação de jovens e adultos passa a ocupar um importante lugar no processo de mediação entre o Estado, tomado por um projeto de desenvolvimento econômico, aliado ao controle social e à sociedade brasileira. Ela foi um dos instrumentos que possibilitaram a coerção social e foi projetada como um símbolo "democrático" em um país que passava por um regime de 'exceção' (FREITAS e BICCAS, 2009).

As principais ações do Regime Militar no campo da educação de adultos foram o Movimento Brasileiro de Alfabetização (MOBRAL), criado em 1967 com o objetivo de fazer frente às elevadíssimas taxas de analfabetismo no país, e a regulamentação do ensino supletivo, através da Lei n. 5692, de 1971. Trata-se da retomada da responsabilidade do Estado em promover a escolarização de adultos, porém a partir de uma perspectiva que se propunha "a recuperar o atraso, a reciclar o presente formando uma mão-de-obra que contribuísse no esforço para o desenvolvimento nacional, através de um novo modelo de escola" (DI PIERRO e HADDAD, 2000, p. 119). A lógica da compensação, mais uma vez, passa a ser o mote da educação de pessoas adultas, na medida em que não é dada nenhuma atenção especial ao preparo de material didático adaptado, formação de professores ou reflexões sobre estratégias didáticas específicas para os cursos supletivos.

De acordo com Di Pierro e Haddad (2000), O MOBRAL partia de uma perspectiva economicista e conservadora que compreendia a alfabetização do adulto como um 
instrumento de modernização do país, sem qualquer preocupação com aspectos pedagógicos ou com a continuidade da sua escolarização. Ele foi criticado pelas suas estratégias aceleradas de alfabetização em larga escala e pelos critérios empregados na verificação de aprendizagem. Criticava-se também o paralelismo da gestão e do financiamento do MOBRAL em relação ao Departamento de Ensino Supletivo e ao orçamento do MEC, além da dúvida que se punha sobre a confiabilidade dos indicadores produzidos na época.

Os sucessivos programas de alfabetização de adultos propostos pelos governos militares, e mesmo pelos que lhes sucederam a partir de 1985, além das dificuldades que apresentaram na adequação das propostas curriculares e metodológicas à faixa etária e ao perfil socioeconômicocultural dos educandos, tenderam quase sempre à apresentação de propostas únicas para todo país, desconsiderando as nossas múltiplas especificidades regionais (OLIVEIRA, 2007, p.85).

A Lei 5692/71 consolida parte significativa do projeto educacional do Regime Militar. Em seu capítulo IV e em regulamentações posteriores estabeleceram-se as diretrizes para o Ensino Supletivo no Brasil, atendendo ao objetivo de recuperar o atraso dos que não puderam realizar a sua escolarização na época adequada. O Ensino Supletivo, neste contexto, é caracterizado por três princípios ou "ideias-força".

O primeiro foi a definição do Ensino Supletivo como um subsistema integrado, independente do Ensino Regular, porém com este intimamente relacionado, compondo o Sistema Nacional de Educação e Cultura. O segundo princípio foi o de colocar o Ensino Supletivo, assim como toda a reforma educacional do regime militar, voltado para o esforço do desenvolvimento nacional, seja "integrando pela alfabetização a mão-deobra marginalizada", seja formando a força de trabalho. A terceira "ideiaforça" foi a de que o Ensino Supletivo deveria ter uma doutrina e uma metodologia apropriadas aos "grandes números característicos desta linha de escolarização". Neste sentido, se contrapôs de maneira radical às experiências anteriores dos movimentos de cultura popular, que centraram suas características e metodologia sobre o grupo social definido por sua condição de classe (DI PIERRO e HADDAD, 2000, p. 119).

A proposta dos militares demonstrava-se enquanto uma educação neutra, desprovida de uma intenção política, ao contrário da perspectiva freireana. Saviani (2008) acentua para a consolidação de um pensamento pedagógico tecnicista no contexto da década de 1970. Inspirada na racionalidade, na eficiência e na produtividade, esta concepção de educação advoga a reordenação do processo educativo de maneira que o torne objetivo e operacional.

Neste sentido, a lógica que se impunha ao discurso do Regime Militar sobre a educação de jovens e adultos ajudava a compor o mito da sociedade democrática brasileira em um regime de exceção, na medida em que a "segunda chance" ofertada pelo Ensino Supletivo se 
encarregaria de corrigir as desigualdades de oportunidades do passado. No entanto, este discurso cai por terra na medida em que o Estado não dá conta de garantir oferta e gratuidade para o Ensino Supletivo e deixa a modalidade a cargo e interesses do setor privado. A partir de 1971, ocorre uma expansão da oferta de cursos supletivos privados, com diferentes formas de flexibilidade, enquanto a oferta pública fica principalmente a cargo de órgãos estaduais específicos para atendimento de adultos, em quase todos os estados da federação (DI PIERRO e HADDAD, 2000). É neste contexto que surge o CEEJA, na época denominado Centro Estadual de Educação Supletiva (CEES), melhor detalhado mais adiante.

A retomada do governo nacional pelos civis, a partir de 1985, promoveu um processo de redemocratização do país e de ampliação de direitos sociais que resultou a Constituição de 1988. A Constituição Cidadã e seus desdobramentos legais, atendendo à parte das demandas dos movimentos sociais ligados à educação que retomavam as experiências de educação popular, promoveram um grande avanço na materialização do direito de acesso de pessoas adultas à educação fundamental. Em seu artigo 208, a Constituição garante que o Estado, pelo menos no plano jurídico, passaria a responsabilizar-se pela oferta de uma educação de jovens e adultos pública, gratuita e universal (BRASIL, 1988). No entanto, ao longo do período de redemocratização até o período atual, a história da EJA no Brasil “é marcada pela contradição entre a afirmação no plano jurídico do direito formal da população jovem e adulta à educação básica, de um lado, e sua negação pelas políticas públicas concretas, de outro" (DI PIERRO e HADDAD, 2000, p. 119).

O MOBRAL foi convertido em Fundação Educar e depois extinto no governo Collor, o que representou um marco no processo de descentralização da escolarização básica de jovens e adultos, pois transferiu a responsabilidade direta dos programas de alfabetização e escolarização fundamental da União para os municípios. Esta medida se insere no contexto de ajuste fiscal promovido por aquele governo, cujo objetivo fundamental era reduzir os gastos públicos federais (DI PIERRO e HADDAD, 2000).

A reforma educacional é iniciada na década de 1990 sob o imperativo neoliberal de redução do gasto público e se espalha por toda América Latina no mesmo período. Paiva (1994) já alertava para o contexto de desmonte do Estado e para a necessidade da formação de adultos sob a perspectiva da educação ao longo da vida em resistência a perspectiva economicista que voltava a ganhar força em meados daquela década. Para ela, os argumentos em favor da EJA explicitamente apoiados sobre uma lógica econômica era uma redução pobre 
e irreal. A perspectiva da cidadania deveria, em seu ponto de vista, ser uma prioridade, na medida em que o neoliberalismo avançava sobre os direitos sociais ainda em fase de gestação.

O discurso técnico-político que justificou a secundarização da formação de adultos na agenda da política educacional apoiava-se no suposto caráter profilático das medidas que priorizavam a formação das novas gerações, com o argumento propalado por organismos multilaterais de crédito e assessoramento de que os investimentos na EJA mostravam-se pouco efetivos (TORRES, 2002 apud DI PIERRO, 2010a, p. 942).

Ao observar o avanço do neoliberalismo e a lenta conquista do direito de acesso à educação, Di Pierro e Haddad (2015) lamentam o aprofundamento das desigualdades e seu impacto na conquista de direitos.

Um dos resultados dramáticos, da combinação entre um mundo mergulhado no neoliberalismo e o avanço do direito à educação, tem sido a frustação diante da constatação de que os esforços por colocar a EJA na agenda dos governos não resultaram em avanços significativos. Tanto no Brasil, quanto no mundo, o número de analfabetos jovens e adultos diminui lentamente e os avanços na escolaridade desse grupo são tímidos. O dilema talvez resida justamente na consequência maior das políticas neoliberais: 0 aprofundamento das desigualdades sociais, cenário em que os potenciais educandos da EJA não poderiam mesmo ver seus direitos realizados (DI PIERRO e HADDAD, 2015, p.199).

As diretrizes da reforma educacional fizeram com que o MEC mantivesse a EJA em posição marginal, reforçando a tendência de descentralização e anunciando o que estaria por vir com a nova Lei de Diretrizes e Bases da Educação Nacional (LDB) e com a criação do Fundo de Desenvolvimento do Ensino Fundamental e Valorização do Magistério (FUNDEF). A nova LDB, Lei n. 9394, aprovada em 1996, já no primeiro governo Fernando Henrique Cardoso, reafirmou o direito à educação de jovens e adultos pública, gratuita e universal, integrou a EJA aos sistemas de ensino, mas não avançou em outros pontos, como nas especificidades psicopedagógicas e na formação docente específica para a EJA (DI PIERRO e HADDAD, 2000).

“Os organismos bilaterais e multilaterais passaram a desestimular abertamente o investimento em educação de adultos" (DI PIERRO et al., 2001, p. 58). Após o novo arranjo que distribuiu as responsabilidades educacionais entre as esferas municipais, estaduais e federal, a maior parte dos recursos destinados a educação foi reunida em cada unidade, através do FUNDEF. À União caberia o papel de distribuir, obedecendo à proporcionalidade das matrículas, e complementar a distribuição de recursos, caso houvesse necessidade. Um veto presidencial na lei de regulamentação do FUNDEF, no entanto, excluiu da contagem as matrículas da EJA, o que restringiu as fontes de financiamento e desestimulou gestores dos 
estados e municípios a ampliarem a oferta de vagas na modalidade. Não só a EJA fícou descoberta de financiamento do FUNDEF, a Educação Infantil e o Ensino Médio também ficaram dependentes apenas de recursos municipais e estaduais. Desta forma, a EJA passou a concorrer com a Educação Infantil e com o Ensino Médio na atração destes recursos e, como nestes dois níveis de ensino os recursos já eram deficitários e sua demanda social muito maior, a expansão do financiamento da educação de jovens e adultos experimentou neste período dificuldades ainda maiores que aquelas já observadas no passado (DI PIERRO, 2010a)

Ao longo da segunda metade dos anos 90, no movimento de ajuste das contas públicas e redução do papel do Estado na garantia de direitos constitucionalmente previstos, foram criados três programas federais de formação de jovens e adultos de baixa renda e escolaridade, mas nenhum deles coordenado pelo Ministério da Educação. Estes programas dependiam de parcerias entre diferentes instâncias governamentais, organizações da sociedade civil, empresas privadas e instituições de ensino e pesquisa: o Programa Alfabetização Solidária (PAS), criado em 1996 com o objetivo de promover uma grande campanha de alfabetização em massa, com financiamento público e privado e uma concepção bastante estreita de alfabetização, seguindo a tendência dos programas anteriores; o Programa Nacional de Educação na Reforma Agrária (PRONERA), criado entre 1997 e 1998, coordenado pelo Instituto Nacional de Colonização e Reforma Agrária (INCRA) e envolvendo a parceria entre o governo federal (responsável pelo financiamento), universidades (responsáveis pela formação dos educadores) e sindicatos ou movimentos sociais do campo, principalmente o Movimento dos Trabalhadores Rurais Sem Terra (MST), com o objetivo de alfabetizar e oferecer escolaridade básica aos trabalhadores rurais assentados em áreas de reforma agrária; e o Plano Nacional de Formação do Trabalhador (PLANFOR), criado em 1995 em parceria com o sistema privado e destinado à qualificação profissional do trabalhador adulto, não se caracterizando, portanto, por uma iniciativa destinada à escolarização de jovens e adultos (DI PIERRO e HADDAD, 2000).

No sentido oposto ao paradigma da educação ao longo da vida, as políticas educacionais voltadas à educação de jovens e adultos no Brasil estavam, na virada do século, aquém dos resultados esperados e marginalizadas diante da reforma educacional que transcorria sob influência de agências internacionais. No contexto de um novo século que se iniciava, Di Pierro e Haddad (2000) identificavam que

Ao mesmo tempo em que as políticas educacionais constrangem o papel dos organismos governamentais na provisão de oportunidades de formação para 
jovens e adultos, crescem a visibilidade e a importância relativa das iniciativas da sociedade civil, difundindo-se as práticas de parceria envolvendo universidades, movimentos sociais, organizações nãogovernamentais, associações comunitárias, sindicatos de trabalhadores, fundações privadas, organismos empresariais e órgãos públicos das três esferas de governo no desenvolvimento de projetos de alfabetização, elevação de escolaridade e/ou de formação profissional. A disseminação de distintas práticas de parceria configura um terreno de experimentação de diferentes concepções do que possam vir a ser, num contexto de reforma do Estado, os serviços públicos não-estatais (DI PIERRO e HADDAD, 2000, p.128).

No final da década de 1990, em contrapartida à marginalização pela qual a EJA vinha sendo submetida, surgem os Fóruns de EJA, criado com o objetivo de organizar demandas e propostas brasileiras ao debate da V Conferência Internacional de Educação de Adultos (CONFITEA V), convocada pela Unesco e realizada em Hamburgo, em 1997. A articulação entre os envolvidos transformou os Fóruns de EJA em um movimento social de defesa da garantia do direito de acesso à educação de jovens e adultos. A partir de 1999, anualmente, os Fóruns realizam os Encontros Nacionais de Educação de Jovens e Adultos (ENEJA), com o objetivo de discutir e influenciar políticas públicas destinadas à EJA (PORTAL FORUNS DE EJA, 2016).

$\mathrm{Na}$ virada do século, especialmente após a eleição de Luiz Inácio Lula da Silva para a presidência e sob influência do paradigma da educação ao longo da vida firmado na $\mathrm{V}$ CONFITEA, novos tempos se anunciavam para a EJA no Brasil. As contradições que envolvem a modalidade a colocariam novamente na pauta central do debate educacional no país "como uma das arenas importantes onde vêm se empreendendo esforços para a democratização do acesso ao conhecimento" (DI PIERRO et al., 2001, p. 58).

O ano de 2003, além de marcar o início do governo Lula, é também o momento de proclamação da Década das Nações Unidas pela Alfabetização (2003-2012). Trata-se de conjunto de metas e ações, de abrangência internacional, sob a coordenação da Unesco, tendo como slogan "Alfabetização como Liberdade". A educação de pessoas adultas é inserida na agenda internacional da educação também através de outros documentos internacionais como os Objetivos de Desenvolvimento do Milênio, assinado em 2000, as metas de Educação para Todos, criadas em 1990 em Jomtien (Tailândia) e renovadas em 2000 em Dakar (Senegal), e a Declaração de Hamburgo, assinada na V CONFITEA.

Em 2001 a Lei n.10.172 que instituiu o I Plano Nacional de Educação (PNE) admitiu ser insuficiente apostar na dinâmica demográfica e atuar apenas junto às novas gerações. $\mathrm{O}$ PNE, de acordo com Di Pierro (2010a) propõe que as ações de escolarização também 
observassem a população jovem e adulta, aderindo à concepção de educação continuada ao longo da vida e priorizando o direito subjetivo de jovens e adultos ao ensino fundamental público e gratuito. As metas trazidas pelo I PNE, portanto, deram à educação de jovens e adultos uma condição de menor marginalização nas políticas educacionais.

O Governo Lula, por um lado, avançou e se distinguiu positivamente do governo anterior em relação à institucionalização da educação de jovens e adultos no sistema de ensino básico e sua inclusão nos mecanismos de financiamento e assistência estudantil. Por outro lado, foi um traço da administração federal neste período a proliferação de iniciativas de EJA geridas por diferentes esferas do governo e precariamente articuladas entre si, como o Programa Brasil Alfabetizado, coordenado pela Secretaria de Educação Continuada, Alfabetização e Diversidade do Ministério da Educação (MEC); o Programa Nacional de Inclusão de Jovens - PROJOVEM, gerido pela Secretaria Nacional de Juventude; o Programa Nacional de Integração da Educação Profissional com a Educação Básica na Modalidade de Educação de Jovens e Adultos, mantido pela Secretaria de Educação Profissional e Tecnológica do MEC; o Programa Nacional de Educação na Reforma Agrária, coordenado pelo Ministério do Desenvolvimento Agrário; e o Exame Nacional de Certificação de Competências - ENCCEJA, realizado pelo Instituto Nacional de Estudos e Pesquisas Educacionais (INEP). Apesar dos esforços, as ações desse governo no campo da EJA não foram capazes de reverter tendências anteriormente instaladas, de modo que nenhuma das cinco metas prioritárias do I PNE relativas a modalidade foi alcançada (DI PIERRO, 2010a).

Em 2004, com o rearranjo interno do Ministério da Educação, as políticas de EJA ficaram quase todas reunidas na Secretaria de Educação Continuada, Alfabetização e Diversidade (SECAD), com exceção do Programa Nacional de Educação na Reforma Agrária (PRONERA), sob a responsabilidade do Incra, o Programação Nacional de Inclusão de Jovens (PROJOVEM URBANO), sob responsabilidade da Secretaria Nacional de Juventude (SNJ) e o Programa Nacional de Integração da Educação Básica com a Educação Profissional na Modalidade de Educação de Jovens e Adultos (PROEJA), sob tutela da Secretaria de Educação Profissional e Tecnológica (SETEC).

Já no segundo mandato do Governo Lula (2007-2010) a EJA recebe um novo impulso, embora ainda em posição secundária em relação a outras modalidades, motivada principalmente pelo Plano de Desenvolvimento da Educação (PDE). Apesar de ter ficado de fora do sistema de aferição de desempenho instituído pelo INEP para a composição do Índice de Desenvolvimento da Educação Básica (IDEB), fazendo com que os resultados de 
aprendizagem da EJA estejam fora do campo de atenção, o INEP centralizou neste período o processo de certificação dos jovens e adultos através do ENCCEJA e do Exame Nacional do Ensino Médio (ENEM). O maior salto, ainda que com inúmeras barreiras, ocorreu com a extinção do FUNDEF e criação do Fundo de Desenvolvimento e Manutenção da Educação Básica e de Valorização dos Profissionais da Educação - FUNDEB, em 2007 (DI PIERRO e HADDAD, 2015).

A criação do FUNDEB trouxe expectativas positivas em relação a política de financiamento da educação, pois aumentou a subvinculação para a educação básica, elevando inclusive a participação financeira da União na sua manutenção. Porém, quanto ao tratamento dado à EJA, dois pontos foram fortemente questionados na regulamentação deste fundo: a limitação de um percentual máximo de quinze por cento dos recursos do FUNDEB para essa modalidade de ensino e a fixação do fator de ponderação atribuído à EJA de 0,7 - ampliado para 0,8 em 2009 - do valor de referência estabelecido às séries iniciais do ensino fundamental "regular" urbano no ano de implantação do FUNDEB, menor dentre todas as etapas e modalidades da educação básica (CARVALHO, 2014).

Apesar da secundarização em relação ao financiamento de outras modalidades, a criação do FUNDEB trouxe esperanças de elevação da oferta e, por conseguinte, das matrículas de EJA em todo o Brasil. Afinal, pela primeira vez, a União passa a se responsabilizar pela designação de um recurso financeiro específico para alunos da EJA, recursos muito maiores que aqueles com os quais a modalidade contava até então (DI PIERRO, 2005b).

O tratamento isonômico entre a EJA e o ensino regular é tarefa urgente. Tal medida colaboraria em muito para que prefeituras e estados passassem a oferecer mais cursos de EJA e/ou aumentassem a qualidade dos existentes. Está patente, sobretudo quando analisamos a evolução dos dados referentes às matrículas de EJA, que esse incentivo não implodirá o Fundeb. Ao contrário, trata-se de medida que cumprirá a dívida histórica que o Estado brasileiro tem com o público jovem e adulto que não teve oportunidades de acessar ou concluir seus estudos na idade esperada (CARVALHO, 2014, p. 13-14).

Nos anos que se seguiram após a criação do FUNDEB, as matrículas presenciais da EJA passaram a ser consideradas também nos programas federais de alimentação e transporte escolar, do livro didático e descentralização de recursos para as escolas, melhorando substancialmente as condições de oferta, de ensino-aprendizagem e de permanência dos estudantes na escola. Em 2010, um acordo entre o MEC e o Ministério da Justiça, cria as Diretrizes Nacionais para a Oferta de EJA em Situação de Privação de Liberdade nos 
Estabelecimentos Penais, prevendo, inclusive, remição de pena pelo estudo (DI PIERRO e HADDAD, 2015).

Diante destes avanços, as condições tornavam-se positivas para o desenvolvimento da EJA no Brasil, mas as expectativas foram frustradas pela queda das matrículas na modalidade. Segundo o Censo Escolar, somadas as matrículas de ensino fundamental e médio, as matrículas foram de 4.985.338 em 2007 para 3.772.670 em 2013, um recuo de 24,3\% em apenas seis anos.

\begin{abstract}
A expectativa gerada por esse conjunto de normas, medidas e programas era a expansão e diversificação da oferta de oportunidades de aprendizagem dos jovens e adultos, com reflexos positivos nos índices de analfabetismo e escolarização da população, convergindo para as metas fixadas nos compromissos internacionais e planos nacionais. Tais expectativas foram frustradas quando os indicadores educacionais constataram o lento progresso nos índices de alfabetização e escolaridade dos brasileiros, e declínio constante das matrículas a partir de 2007, resultados que colocaram as políticas de EJA na berlinda (DI PIERRO e HADDAD, 2015, p. 2010).
\end{abstract}

Os dados estatísticos observados no início da atual década, apontam para evidências de um longo e lento processo de avanço nas taxas de alfabetização e escolaridade. As taxas de alfabetização da população brasileira com 15 anos ou mais avançaram apenas três pontos percentuais entre 2004 a 2013, recuando de 88,5\% para 91,5\%. Este dado expressa muito mais a expansão do acesso à escola nas novas gerações do que a ação de programas de alfabetização de adultos. De acordo com o Indicador Nacional de Alfabetismo (INAF), aplicado à população de 15 a 65 anos, a proporção de analfabetos absolutos teve recuo de sete pontos percentuais, evoluindo dos 13\% em 2002 para 6\% em 2011 (DI PIERRO e HADDAD, 2015).

A primeira gestão da Presidenta Dilma Rousseff foi marcada pela reunião de diversos programas federais ligados à EJA no SECADI - Secretaria de Educação Continuada, Alfabetização, Diversidade e Inclusão, com destaque para a criação do Programa Nacional de Acesso ao Ensino Técnico e Emprego (PRONATEC). Apesar do apelo publicitário, o PRONATEC vem sendo criticado por parte dos pesquisadores e educadores do campo por seu caráter privatizante, estruturado através da transferência de recursos públicos ao Sistema $\mathrm{S}$ e outras instituições privadas. Outro ponto de crítica é a oferta de cursos de curta duração voltados à qualificação pontual para o posto de trabalho, de modo desarticulado à educação básica. Esta visão rompe com a promissora perspectiva de integração entre a EJA e a educação profissional, pensada em outros programas criados na gestão do Presidente Lula, como o PROJOVEM e o PROEJA. Destacam-se também a ausência de mecanismos de gestão 
democrática, e de instrumentos de monitoramento e avaliação dos resultados do PRONATEC (DI PIERRO e HADDAD, 2015).

Diante desta breve análise da trajetória recente da EJA no Brasil, a compreensão dos principais entraves que ainda marginalizam a modalidade é fundamental para a construção de uma visão ampla sobre o tema. Com avanços e retrocessos, a EJA vem se firmando, ao longo da história, como um espaço de democratização do conhecimento. No entanto, ainda não é uma modalidade educativa provida de uma identidade que lhe garanta, diante das políticas públicas e da academia, o reconhecimento e valorização de suas especificidades.

\subsection{Ensino Supletivo: a EJA sob o paradigma compensatório}

Para além das discussões vinculadas aos programas que envolvem a educação de jovens e adultos e sua distribuição de recursos, outros entraves, destacados pela literatura do campo, precisam ser desvelados. Estes entraves estão ligados à concepção compensatória que ainda predomina na modalidade e que afetam fortemente aspectos como seu currículo, material didático, formação docente, avaliação, entre outros aspectos que desconsideram as especificidades pedagógicas necessárias para contribuir com o esforço de criar uma identidade própria da modalidade.

De acordo com Di Pierro (2008), nos mais diversos contextos da América Latina, a EJA é chamada a cumprir basicamente quatro funções sociais entendidas como primordiais. A primeira se refere à necessidade de acolhida de migrantes, principalmente aqueles oriundos do campo no processo de êxodo rural. A segunda função refere-se à necessidade de elevar o nível educativo dos jovens e adultos que não tiveram a mesma oportunidade de acesso à educação das novas gerações. Em terceiro lugar, a EJA também se configura como um canal de reinserção no sistema educativo de jovens dele excluídos precocemente, além de possibilitar a aceleração de estudos daqueles que se encontram em situação de atraso. Por fim, é também função da EJA oportunizar atualização e qualificação profissional, além de fruição cultural ao longo da vida dos indivíduos adultos.

Partindo destas funções, é possível, levando sempre em conta a enorme diversidade dos sujeitos da EJA, traçar um perfil do sujeito ao qual a EJA se destina:

A categoria que melhor define os sujeitos da EPJA, entretanto é a da exclusão, por que abarca o conjunto de processos socioeconômicos e culturais que permitem explicar a distribuição desigual do analfabetismo e do atraso escolar nas sociedades, incluindo as variáveis de gênero, geração, língua e etnia, considerando ainda a distribuição socioespacial da pobreza nas regiões geográficas, zonas rurais e urbanas e no interior das cidades (DI PIERRO, 2008, p.373). 
Neste sentido, entre os sujeitos da EJA, sobressaem-se os migrantes e imigrantes oriundos de regiões pobres e das periferias dos grandes centros urbanos, com destaque para as mulheres, negros, indígenas, população carcerária e jovens que não tiveram êxito na escola regular. Trata-se, portanto, de um grupo fortemente marcado pela exclusão e pela diversidade. A exclusão é, aliás, entendida por Oliveira (2001) como um traço cultural dos sujeitos que procuram a EJA, na medida em que se destina àqueles a quem o direito á educação foi historicamente negado. A educação cumpre, desta forma, um papel de diferenciação e de instrumento de consolidação das desigualdades sociais.

Se, antes, as desigualdades sociais reproduziam-se principalmente pela exclusão de certas parcelas da população dos sistemas de ensino, com a sua universalização, as desigualdades são repostas pela diferenciação da experiência escolar em termos de qualidade (RIBEIRO, 2014, p.18)

Di Pierro et al (2001) compreendem os sujeitos da EJA dentro de três tipos trajetórias escolares: a) aqueles que iniciam a escolaridade já na condição de adultos trabalhadores; b) aqueles adolescentes e jovens que ingressaram na escola regular e abandonaram por motivos ligados ao trabalho ou à movimentos migratórios, por exemplo; c) e aqueles que ingressaram e cursaram recentemente a escola regular, mas acumularam defasagens entre a idade e a série cursada.

Apesar de jovens e adultos serem entendidos como dois subgrupos inseridos em um grupo relativamente homogêneo, não é possível tratá-los, desconsiderando suas singularidades.

Embora frequentemente constituindo dois subgrupos distintos (o de "jovens" e o de "adultos"), tal grupo se define como relativamente homogêneo ao agregar membros em condição de "não crianças", de excluídos da escola e de pertinente a parcelas "populares" da população (em oposição às classes médias e aos grupos dominantes), pouco escolarizadas e inseridas no mundo do trabalho em ocupações de baixa qualificação profissional e de baixa remuneração (OLIVEIRA, 2001, p. 41).

Em convergência com esta diversidade de sujeitos, as políticas de EJA devem ser necessariamente abrangentes, diversificadas e altamente flexíveis, levando em conta três pontos fundamentais na visão de Di Pierro et al (2001). O primeiro refere-se à autonomia dos sujeitos em traçar sua biografia formativa.

Considerando a singularidade das conexões que cada um estabelece, em função de suas experiências e saberes anteriores e, também, a multiplicidade de conexões possíveis, não faz sentido pressupor um trajeto único e obrigatório para todos os sujeitos em seus processos de aprendizagem (OLIVEIRA, 2007, p. 87). 
O segundo denuncia a necessidade repensar a demanda por educação concebendo a oferta educativa a partir de modalidades diversificadas, visando atender a todos em sua diversidade.

A experiência internacional recomenda flexibilizar currículos, meios e formas de atendimento, integrando as dimensões de educação geral e profissional, reconhecendo processos de aprendizagem informais e formais, combinando meios de ensino presenciais e a distância, de modo a que os indivíduos possam obter novas aprendizagens e a certificação correspondente mediante diferentes trajetórias formativas (DI PIERRO et al., 2001, p. 71).

O terceiro, por fim, exalta a importância de a EJA reconhecer os conhecimentos adquiridos pelos sujeitos fora da escola, isto é, valorizar os saberes experienciais dos estudantes. Isto porque não só a escola, mas outras instituições e espaços sociais têm valor formativo e cabe à escola aproveitar ao máximo o potencial destes espaços e reconhecer a legitimidade do conhecimento adquirido neles (DI PIERRO et al.,2001).

Também diante desta diversidade que caracteriza os sujeitos da EJA, a constituição de um currículo específico para a modalidade é premente. Afinal, "cada sujeito traz para dentro de sala de aula redes de saberes, tecidas em seus múltiplos espaços/tempo de experiência, e participa das redes tecidas na sala de aula" (OLIVEIRA, 2007, p.94). Tratar do currículo da EJA, neste sentido, significa também tratar da superação da perspectiva compensatória, da tendência cientificista, tecnicista e disciplinarista, que dificultam o estabelecimento de diálogo entre o conhecimento escolar e as experiências vividas pelos educandos.

Na percepção de Oliveira (2007), a infantilização e a reprodução do currículo da escola regular são ainda os principais obstáculos para a consolidação de uma identidade específica da EJA. O distanciamento entre os conteúdos escolares e seu significado social para os estudantes reforçam o processo de exclusão e evasão. "Ou seja, se, notadamente de EJA, os conteúdos aparentemente abstratos fossem trabalhados em relação com sua utilidade concreta, a escola poderia ter, na adesão dos alunos à necessidade de aprendizagem deles (...)" (OLIVEIRA, 2007, p.90).

Há, na medida em que o currículo não é direcionado às especificidades da EJA, uma incompatibilidade entre a escola e a vivência dos sujeitos adultos, que muitas vezes está há décadas distante do ambiente escolar, resultando no fracasso do processo de retomada da aprendizagem formal.

A lógica que preside a organização da escola e as propostas de trabalho que ela busca pôr em prática trazem embutidos valores, ideais e concepções de mundo bastante diferentes do público que a frequenta, o que dificulta 
imensamente ao educando realizar o enredamento daquilo que se diz e se propõe na escola com os saberes que traz de sua vivência. Com isso, os processos de aprendizagem não se efetivam de acordo com as expectativas, nem de uns, nem de outros (OLIVEIRA, 2007, p.91).

Nesta perspectiva crítica, seria necessário desenvolver novas formas de compreensão, em contrapartida à tendência dominante no currículo da EJA, isto é, a compreensão de um currículo em permanente diálogo com a escola e não apenas pensado por especialistas, que navegue pelos diversos campos do conhecimento e entenda os conteúdos escolares como meio para uma vida mais plena. É preciso, para isto, caminhar na direção do abandono dos conteúdos formais clássicos em prol de outros que sejam operacionais e contextualizados, que desenvolvam a consciência crítica e capacitem os sujeitos da EJA para a ação social (OLIVEIRA, 2007). Um currículo alicerçado nestas proposições consubstanciaria um caminho para rompimento com a perspectiva compensatória predominante na EJA e a aproximaria de uma nova perspectiva: a educação ao longo da vida.

É fulcral, diante destas observações, que, além do currículo, estratégias didáticas específicas sejam desenhadas para o trabalho docente com alunos jovens e adultos. Isto certamente inclui fortalecer a formação docente para a EJA, discutida no primeiro capítulo dessa dissertação, mas também a produção de materiais didáticos específicos para a modalidade.

Di Pierro e Haddad (2015) enxergam quatro grandes linhas de força como tendências predominantes da EJA no Brasil. A primeira refere-se ao alargamento dos direitos declarados aos jovens e adultos, que ultrapassa a simples alfabetização e hoje se estende ao ensino médio e profissional para todos. A segunda refere-se à institucionalização da EJA nas políticas públicas de educação básica, especialmente diante dos numerosos programas experimentados nas últimas décadas pelo MEC e que, se não atingiram o resultado esperado, pelo menos contribuíram para a reorientação de políticas futuras. A terceira refere-se ao desafio colocado pela perspectiva da educação ao longo da vida, que imputa sobre as políticas educacionais a necessidade de implementar ações efetivas para sua plena realização. A quarta ideia força, por fim, refere-se à necessidade de superação da leitura instrumental, presente na agenda brasileira e internacional, que tem sido feita do conceito de aprendizagem ao longo da vida, visando principalmente à competitividade econômica e qualificação para o mercado de trabalho, em detrimento da formação integral dos sujeitos.

O uso pedagógico das TDIC, desta forma, será incorporado à EJA, a partir de uma perspectiva crítica, se a identidade da modalidade estiver desvinculada da perspectiva 
compensatória e caminhando na direção da aprendizagem ao longo da vida. Desta forma, a formação de professores para o uso das TDIC a partir de uma perspectiva crítica, levando em conta o empoderamento freireano como objetivo final da inclusão digital de estudantes jovens e adultos, se alinha com uma EJA voltada para a formação continuada ao longo da vida.

\subsection{EJA para todos: o paradigma da educação ao longo da vida}

De modo geral, a educação de jovens e adultos é comumente colocada em posição secundária em relação à educação de crianças e adolescentes, no que se refere tanto às políticas públicas de financiamento quanto aos estudos acadêmicos no campo da educação. Entretanto, a educação de jovens e adultos pode ser considerada "como uma das arenas importantes onde vêm se empreendendo esforços para a democratização do acesso ao conhecimento" (DI PIERRO et al., 2001, p. 58), se percebida a partir de uma abordagem mais ampla e sistêmica da educação no Brasil.

Três grandes entraves devem ser levados em conta na discussão sobre a inclusão digital e o uso pedagógico da TDIC como possibilidade de empoderamento freireano na EJA. Isto porque toda esta discussão está pautada nas peculiaridades desta modalidade de ensino, na medida em que a pesquisa de campo deste relatório se dá em um CEEJA, unidade escolar que atende exclusivamente jovens e adultos. Estes entraves referem-se às dificuldades de fortalecer uma identidade própria para a EJA no Brasil e implicam reprodução de práticas de outras modalidades de ensino.

A predominância da perspectiva compensatória na EJA é o maior dos entraves. Esta visão está ligada à concepção do ensino supletivo, isto é, a reposição de estudos não realizados na infância e na adolescência. A concepção compensatória alimenta visões preconceituosas sobre o adulto analfabeto ou de baixa escolaridade. Este olhar subestima os alunos, dificulta que os professores valorizem seus conhecimentos prévios e a cultura adquiridos por eles no convívio social e no trabalho (DI PIERRO, 2005a).

A visão compensatória da EJA se limita a reproduzir as práticas e o currículo das escolas regulares e, assim, dificulta ações para a promoção da inclusão digital e o uso pedagógico das TDIC com o objetivo de inserção dos sujeitos no mundo digital. O modelo de suplência, aligeirado e enxuto, garante ainda menos oportunidades para o educando aproximar-se das tecnologias. Da mesma forma, há pouco espaço dedicado à formação integral para a cidadania, restringindo o adulto à aprendizagem de conteúdos escolares ou a formação para o mercado de trabalho. 
O segundo entrave para o acesso dos adultos pouco escolarizados às tecnologias referese ao currículo da EJA, que reproduz a visão cientificista de toda a educação básica. Nesta modalidade, o ensino se mantém excessivamente tecnicista e disciplinarista (OLIVEIRA, 2007, p.86). Na perspectiva não instrumental do uso das tecnologias, o diálogo e a construção coletiva do conhecimento devem ser os eixos (des)centralizadores do processo. Desta forma, o currículo engessado, o formalismo e a fragmentação dos saberes precisam também ser superados para almejar-se uma educação de jovens e adultos, em que não faz sentido pressupor uma trajetória única para todos os sujeitos, que ao menos projete o empoderamento freireano.

O terceiro entrave está relacionado ao processo de formação de professores para atuar na educação de jovens e adultos, já discutido em capítulo anterior. Há, como já dito, falta de formação específica dos educadores que atuam nessa modalidade de ensino, resultando numa transposição inadequada do modelo da educação básica regular (RIBEIRO, 1999). Este entrave implica dois outros problemas: a infantilização dos sujeitos e o surgimento de uma visão assistencialista da educação de jovens e adultos.

Como forma de superar estes problemas, é validar considerar "a valorização do diálogo como princípio educativo, com a decorrente assimilação da noção de reciprocidade na relação professor-aluno" (RIBEIRO, 1999, p. 193). Para além desta proposta, é preciso que a educação de jovens e adultos perceba-se incluída no paradigma da educação ao longo da vida, em seu sentido mais largo. Este pode ser o alicerce para o rompimento com a perspectiva compensatória e o currículo engessado na EJA. Estes são, por conseguinte, empecilhos para promoção do empoderamento a partir da inclusão digital, na medida em que cerceiam a criatividade, a aprendizagem colaborativa e a educação dialógica.

O conceito de educação ou aprendizagem ao longo da vida é multidimensional e objeto de disputa entre os teóricos que defendem uma perspectiva de formação humanística, voltada à formação integral e à emancipação, e os organismos nacionais e internacionais, que se apropriam do conceito para planejar e implantar políticas públicas de formação profissional, a partir de uma perspectiva instrumental. Em sua essência, o conceito de aprendizagem ao longo da vida inclui diversas esferas, como o desenvolvimento pessoal ao longo dos ciclos de vida, a aquisição de competências laborais, o manejo de tecnologias, a aprendizagem de línguas e de relações multiculturais, a socialização política e a participação cidadã (TORRES, 2015). 
De acordo com Lima (2007), a abordagem original do conceito no campo humanista e crítico da educação de adultos transbordou para a política educativa em geral, em uma apropriação dominantemente economicista, tecnocrática e gerencial. Nas políticas públicas, o conceito passa por uma leitura de caráter instrumental com vistas à competitividade econômica e assentada na teoria do capital humano ${ }^{22}$ (SANTOS, 2004), por meio da qual se busca satisfazer requisitos de qualificação para o mercado de trabalho, em detrimento da formação integral e da emancipação do sujeito e sem compromisso com a universalidade do direito a aprender (LIMA, 2007).

A discussão proposta por Alheit e Dausien (2006) coloca uma questão fundamental para a reflexão sobre este conceito que, segundo eles, permanece mal definido. De acordo com os autores, é possível construir um novo conceito de educação ao longo da vida, mais adequado às novas condições estruturais das sociedades pós-industriais, a partir da sinergia entre os processos de aprendizagem formais, que ocorrem nas instituições de formação clássicas, não formais, que se desenvolvem em outros ambientes, como associações, locais de trabalho, movimentos sociais etc. e informais, que não são empreendidos intencionalmente e que acompanham a vida cotidiana.

O interesse dessa nova compreensão do conceito de educação reside em estabelecer a sinergia desses diferentes modos de aprendizagem. A aprendizagem não deve ser somente, e sistematicamente, ampliada para toda a duração da vida. Ela deve também se desenvolver "lifewide", quer dizer, generalizar-se para todos os domínios da vida, para isso estabelecem-se, portanto, ambientes de aprendizagem nos quais diferentes modos de aprendizagem encontram-se para complementarem-se organicamente (ALHEIT e DAUSIEN, 2006, p.178).

Há, no entanto, uma contradição interna neste novo conceito descrito por Alheit e Dausien (2006): essa nova aprendizagem insere-se num quadro econômico e político cujos objetivos são competitividade e empregabilidade, ao mesmo tempo em que se propõe a promover uma aprendizagem integral, como transformação de experiências, de saberes e de modos de vida dos sujeitos.

Lima (2007) também identifica estas duas direções contraditórias e, em sua obra Educação ao longo da vida: entre a mão direita e a mão esquerda de Miró, faz uso da metáfora dialética das mãos do artista Miró para explicar as duas correntes abrangidas pela educação ao longo da vida. Citando um poema de João Cabral de Melo Neto, o autor explica

\footnotetext{
22 "Esta formulação temcomo ponto central a alocação da atividade educacional como componente da produção,que deve merecer, por isso, atenção especial dos planejadores de políticas educacionais, traduzida em intencionalidade, análise rigorosa das taxas de retorno e investigação da produtividade alcançada com os investimentos" (SANTOS, 2004, p.01).
} 
que a mão direita do artista, a partir do momento em que se torna sábia e muito destra, perde a capacidade de se reinventar, e sua mão esquerda, menos habilidosa e funcional, torna-se a mais criativa e a mais desejosa por aprender.

Em síntese, a metáfora simboliza que a mão direita representa um olhar para o conceito de educação ao longo da vida pautado pela adaptação e orientação dos sujeitos às transformações do mundo contemporâneo, em especial às novas relações de trabalho, empregabilidade e competitividade. A mão esquerda, por outro lado, representa a perspectiva da educação ao longo da vida orientada para a emancipação humana e transformação social. Não se trata de optar por uma direção, mas, segundo Lima (2007), de pensar em um projeto ambidestro para equacionar a polissemia do conceito de educação ao longo da vida.

Isto significa, em última análise, admitir o já antes referido projeto de uma educação ao longo da vida com caráter ambidestro, ainda que reconhecendo a necessidade de maior expressão da "mão esquerda" face ao seu potencial de reinvenção e de aprendizagem novo. Reconhece-se, em todo o caso, que um certo grau de adaptação é inerente a qualquer projeto de educação ao longo da vida, desde logo quando esse projeto confere centralidade à vida dos adultos, à sua leitura do mundo, às suas aprendizagens experienciais ou, até, do tipo tentativa-erro. Mas isto implica também reconhecer a substantividade da vida ao longo da educação e das aprendizagens permanentes dos indivíduos, e não o curso da vida reduzido a uma interminável sucessão de formações e de aprendizagens úteis e eficazes, segundo apenas uma determinada racionalidade de tipo econômico e gerencial [...] (LIMA, 2007, p.10).

É categórico concluir que há um duplo ponto de vista acerca da concepção de educação ao longo da vida, de acordo com Alheit e Dausien (2006): a) o primeiro refere-se a "um interesse principalmente motivado pela política de formação vinculada à mudança das condições da sociedade do trabalho e da educação" (ALHEIT e DAUSIEN, 2006, p. 180); b) o segundo refere-se às implicações da educação ao longo da vida na lógica da construção biográfica, das experiências vivenciadas e da ação dos sujeitos e grupos sociais, isto é, a educação ao longo da vida compreendida como um processo biográfico de formação integral dos sujeitos (ALHEIT e DAUSIEN, 2006).

A perspectiva de educação de jovens e adultos conjecturada neste estudo tem como pressupostos teóricos a compreensão da educação ao longo da vida como um processo biográfico, que se dá pela sinergia de diversas formas de aprender (ALHEIT; DAUSIEN, 2006) e também a partir de uma perspectiva ambidestra (LIMA, 2007), que leva em conta a adequação e formação profissional dos sujeitos às novas relações de trabalho (mão direita), ao mesmo tempo em que tem em vista uma formação humanística e emancipadora (mão esquerda). 
A ideia de inclusão digital também pode ser pensada a partir desta perspectiva. É fundamental que ela colabore na qualificação dos sujeitos para sua melhor integração aos interesses do mercado de trabalho e da educação, mas este não deve ser seu fim. A mão esquerda da inclusão digital seria aquela que procura transcender o uso instrumental das TDIC, ultrapassar a simples alfabetização digital, visando uma formação mais completa e crítica, capaz de desestabilizar as relações de poder, com vista ao exercício pleno da cidadania e à transformação social. A mão esquerda, neste sentido, seria capaz de promover o letramento digital e, por conseguinte, o empoderamento freireano.

Do ponto de vista conceitual, há um processo de disputa por significações dos três conceitos-chaves apresentados neste capítulo: inclusão digital, empoderamento e educação ao longo da vida. A polissemia destes conceitos e a sua apropriação por forças hegemônicas representadas por organismos internacionais torna-os verdadeiras arenas de disputa semântica. Desta forma, é preciso, em síntese, sistematizar estas disputas, a fim de posicionar este estudo e constituir em sua base o arcabouço conceitual que será utilizado na análise dos dados referentes à contribuição da formação continuada em serviço "Mídias Digitais na Educação de Jovens e Adultos" para o repensar da prática docente, amparada na utilização crítica das TDIC, de modo empoderar os professores, ao situar sua prática docente em uma perspectiva autoral.

O conceito de inclusão digital, como explicitado principalmente por Silva et al (2005), Sorj e Guedes (2005) e Buzato (2008; 2010), é um campo em disputa, na medida em que é comumente apropriado por políticas públicas de modo a ser entendido como simples garantia de acesso ao consumo de produtos tecnológicos ou entendido como qualificação de mão-deobra para as exigências atuais do mundo do trabalho, tendo por base a teoria do capital humano (SANTOS, 2004). Na educação, esta visão reproduz as mesmas práticas, os mesmos currículos e as TDIC tornam-se apenas instrumentos de reprodução daquilo que já se faz. Esta pesquisa parte da imprescindibilidade de superar esta perspectiva, em função da necessidade de uma formação de professores e estudantes da EJA para a utilização crítica dos recursos da cultura digital, visando situá-los em uma perspectiva autoral e colaborativa. Este processo só será possível se o conceito mais lato de letramento digital for adotado como fundante do processo de inclusão digital e se a escola for compreendida como seu locus primeiro e natural.

Associado ao sentido dado ao conceito de letramento digital, emerge nesta discussão teórica a acepção de Paulo Freire do conceito de empoderamento. Tendo por base Freire e Shor (1986) e suas comentadoras Baquero (2012) e Pesce (2013a), é preciso demarcar a 
significação atribuída ao termo empoderamento, pois este é também apropriado por forças hegemônicas ligadas principalmente aos princípios do liberalismo norte-americano. Estão presentes neste debate duas perspectivas distintas de empoderamento. A primeira, de matriz tocquevilliana, concebe a sociedade civil como uma esfera que possui certa autonomia em relação ao Estado e se posiciona em favor de um empoderamento individual e organizacional como fortalecimento da esfera privada, argumentando a necessidade de os sujeitos e comunidades resolverem, por si próprios, seus problemas. A segunda, de inspiração gramsciniana e freireana, denuncia a apropriação indevida do termo, pelo neoliberalismo e concebe a sociedade civil como espaço público de transformação de pensamentos em ação, espaço de emancipação dos grupos dominados e excluídos. Nesta perspectiva situam-se as pesquisas sobre empoderamento emancipatório de Paulo Freire e também nela se assenta a importância desta pesquisa investigar o impacto de uma formação de professores para uso pedagógico das TDIC na educação de jovens e adultos, na medida em que elas podem empoderar a classe trabalhadora para a práxis necessária à transformação social.

O empoderamento freireano a partir da inclusão digital na educação de jovens e adultos é um caminho viável, desde que assentado em uma perspectiva emancipatória e integral de EJA. Desde as propostas de Paulo Freire voltadas ao letramento de adultos e alicerçada em sua concepção de pedagogia, o conceito de educação ao longo da vida é também apropriado por forças do mainstream. De acordo com Alheit e Dausien (2006), Lima (2007) e Torres (2015), o conceito é disputado pelas forças progressistas com a ideia mais vinculada à educação de adultos voltada ao atendimento das demandas do mundo do trabalho, também amparada pela teoria do capital humano (SANTOS, 2004). A educação ao longo da vida, nesta perspectiva, significaria oferecer formações, para que a classe trabalhadora se adeque às exigências do mundo corporativo, ainda mais diante das novas e perversas dinâmicas provocadas pela globalização e pelo avanço do neoliberalismo. A visão de educação ao longo da vida, na qual se sustenta o pensamento freireano e se fundamenta o presente estudo, é concebida a partir de um olhar mais humanista, voltado à formação integral, que pode se dar em todas as esferas da vida, orientada para a emancipação humana e transformação social.

Evidentemente, diante das exigências do mundo do trabalho, a educação de jovens e adultos e a inclusão digital não podem se furtar a formar os sujeitos também para o mercado de trabalho. Este objetivo só não deve, dentro da perspectiva aqui discutida, ser a finalidade maior desta modalidade de ensino. 
O referencial teórico sobre a educação de jovens e adultos no Brasil permite contextualizar o CEEJA dentro da perspectiva dos autores que tratam da história da EJA no Brasil e das diferentes perspectivas presentes na modalidade. Deste modo, é possível centrar o olhar ao processo histórico e à organização legal do CEEJA, de modo à facilitar a compreensão do locus em que se deu o curso de formação em tela e pesquisa de campo.

\subsection{Histórico e Organização do CEEJA}

\section{a) De 1976 a 2011}

Publicado em 1985 pela Coordenadoria de Estudos e Normas Pedagógicas (CENP) da Secretaria de Educação do Estado de São Paulo o documento técnico/orientador Para Conhecer um Centro de Educação Supletiva (CES) é o primeiro documento oficial que procurou sistematizar a organização administrativa e pedagógica da modalidade de ensino supletivo planejado pela CENP para os CES, mais tarde chamados de Centros Estaduais de Educação Supletiva (CEES). A equipe responsável pela implementação do projeto, composta por Hiromi Shibata, Luci Tiho Ikari, Maria Eneida Fachini Saliba e Paulo de Tarso Galembeck organiza, neste material, instrumentos para desencadear um processo de reflexão crítica que possibilite a execução de ações planejadas para efetivar a criação de unidades do CEES (SÃO PAULO, 1985).

De acordo com Cunha e Teodoro (2015), o projeto inicial para implantação dos CEES no estado de São Paulo foi elaborado em 1976, baseado em estudos realizados pelo Ministério da Educação (MEC), que já havia instalado algumas destas instituições em outras unidades federativas. Em 1977, com verba proveniente do MEC, é criado o CEES "Dona Clara Mantelli”, que inicia suas atividades de atendimento a alunos da zona leste de São Paulo em 1981. A partir daí, difunde-se a ideia de expansão dos CEES para outras regiões do estado de São Paulo, por meio de convênios firmados entre a Secretaria de Educação do Estado de São Paulo e as Prefeituras Municipais.

O documento Para Conhecer um Centro de Educação Supletiva define o CES como uma "agência educacional não-formal, onde são respeitadas as individualidades do homem e os valores do contexto comunitário" (SÃO PAULO, 1985, p. 7). Seriam atribuições do CEES atender a jovens e adultos que: a) não tenham concluído, na época própria, a escolarização regular, para os quais se destinariam os cursos de suplência; b) necessitam qualificação profissional, para os quais se destinariam os cursos de preparação ou atualização para o mercado de trabalho; c) desejam participar de atividades de enriquecimento cultural, para os 
quais se destinariam os cursos de suprimento, visando a educação permanente em sua ampla dimensão (SÃO PAULO, 1985).

É perceptível neste documento a intenção de associar o CES não somente à educação supletiva, mas também à educação profissional e comunitária. É presente em diversos trechos a incipiência da ideia de aprendizagem ao longo da vida, ainda que esta perspectiva adquira maior força somente após a publicação da Declaração de Hamburgo, documento síntese da V CONFITEA, realizada em 1997, em Hamburgo, Alemanha. Os autores do documento, no entanto, fazem uso do termo "educação permanente", ao se referir à função do que chamam de cursos de suprimento.

Atualmente, o maior interesse da clientela recai sobre os programas de suplência, porque a sociedade de modo sempre crescente, exige dos indivíduos a escolaridade básica. Nem por isto, contudo, deve-se deixar de lado a importância da função de suprimento, como expressão mais nítida da meta de educação permanente (SÃO PAULO, 1985, p. 8).

Além disso, o documento apresenta algumas sugestões de linhas de ação para otimizar a atuação de um CES, onde indicam, por exemplo,

- Apoio à preservação e valorização das expressões culturais da comunidade.

- Incentivo à participação da comunidade na apresentação de sugestões para o desenvolvimento de novas ações (...).

- Realização de trabalhos comunitários visando à solução de problemas ou melhoria de condições, no que se refere à alimentação, saneamento básico, etc.

- Contato do CES com Associações, Sindicatos, Empresas, Agremiações e outros órgãos (...).

- Promoção de atividades enriquecedoras do currículo: círculos de estudos, palestras, debates (SÃO PAULO, 1985, p. 18).

Apesar da perspectiva progressista do documento, claramente influenciado pela perspectiva da educação popular, não é possível afirmar, sem dados pormenorizados das práticas realizadas nos CEES, se os cursos de suprimentos cumpriam, de fato, a função da educação permanente de jovens e adultos em sua dimensão cultural e profissional. $\mathrm{O}$ fato é que a partir de 2011, quando os CEES são reorganizados em CEEJA, como se verá adiante, a preocupação com essa formação mais ampla e permanente desaparece de qualquer resolução ou documento orientador, o que indica uma ampliação da preocupação com a escolarização básica e um revigoramento da perspectiva compensatória de EJA.

Quanto às características metodológicas descritas no documento, fica claro o objetivo de criar condições de atendimento para um número maior de estudantes, a partir da adequação didático-pedagógica e da flexibilidade normativa. 
A metodologia utilizada no CES deverá estar voltada para o atendimento das características, aptidões, disponibilidade de tempo, ritmo de aprendizagem, necessidades e interesses próprios e experiências de cada aluno. Para atender a essa proposta, emprega-se, basicamente, a instrução personalizada, através da Unidade de Estudo planejadas para facilitar a aprendizagem do aluno por si mesmo (SÃO PAULO, 1985, p. 9).

A autoinstrução e o respeito ao ritmo e características individuais de aprendizagem de cada estudante é elemento central no escopo metodológico apresentado pelo documento da CENP. Para sua efetivação, o CEES deveria permitir ao aluno: a) diagnosticar e considerar os conhecimentos adquiridos de forma assistemática pelos candidatos; b) aproveitar estudos anteriores já realizados; c) matrícula por disciplina; d) usufruir de alternativas que substituam a frequência diária obrigatória; e) não definir tempo ou carga horária obrigatória; f) evitar calendários escolares centrados na seriação; g) participar ativamente do processo de ensinoaprendizagem; h) concluir o curso, em maior ou menor tempo, de acordo com seu ritmo de aprendizagem; i) optar, quando possível, pelo emprego de tecnologia educacional adequada à natureza do processo de aprendizagem (SÃO PAULO, 1985).

Estas características, elaboradas desde a concepção do primeiro CES paulista, atravessaram mais de três décadas com poucos ajustes. A figura do professor tradicional, a partir da descrição do documento, é substituída pelo orientador de aprendizagem, responsável pelo "aprender a aprender", isto é, orientar o estudante sobre a melhor forma de estudar cada uma das disciplinas escolhidas. Os princípios da ajustabilidade, da flexibilidade e abertura fundamentam o documento que orientou a expansão dos CES entre as décadas de 1980 e 2000 e estabeleceu as diretrizes para o seu funcionamento.

Em 2011 ocorreu reestruturação de parte da Secretaria Estadual de Educação de São Paulo, com o Decreto n. 57.141, de 18 de julho de 2011, que estabeleceu o início das atividades do Centro de Educação de Jovens e Adultos (CEJA), que é hoje o setor responsável pela modalidade da EJA em toda rede estadual de ensino, tanto para o curso de presença obrigatória, quanto para o curso de presença flexível realizado nos agora chamados Centros Estaduais de Educação de Jovens e Adultos (CEEJA).

\section{b) A Resolução 77/2011 e os atuais pressupostos pedagógicos do CEEJA}

Em 06 de dezembro de 2011 foi publicada a Resolução SE n. 77/2011, que normatiza o funcionamento dos CEEJA. Esta resolução dispõe sobre a organização e o funcionamento dos cursos, retoma alguns dispositivos metodológicos apresentados no documento Para Conhecer um Centro de Educação Supletiva (CES), de 1985, ao mesmo tempo em que abandona outros. 
Para conhecer, efetivamente, a estrutura e o funcionamento dos CEEJA é preciso atentar para alguns pontos mais fundamentais do documento legal. O primeiro deles é a preferência pelo atendimento individualizado aos alunos:

Os CEEJAs oferecerão atendimento individualizado a seus alunos, com frequência flexível, sendo organicamente estruturados com o objetivo de atender preferencialmente o aluno trabalhador que, por motivos diversos, não possui meios ou oportunidade de desenvolver estudos regulares, na modalidade presencial, referentes à(s) etapa(s) da educação básica que ainda não cursou (SÃO PAULO, 2011, art. $2^{\circ}$ ).

O atendimento individualizado é há mais de uma década questionado por Di Pierro (2005a), na medida em que não possibilita ao adulto a experiência escolar completa, em que o diálogo com os pares e a produção coletiva de conhecimento sejam valorizados. Segundo a autora, a EJA, ao invés de incorporar as ricas contribuições da educação popular do início da década de 1960,

atendeu ao apelo modernizador da educação a distância e aderiu aos preceitos tecnicistas da individualização da aprendizagem e instrução programada, que fundamentam a difusão das modalidades da educação nãopresencial em centros de estudos supletivos e telecursos, que se somaram aos cursos presenciais na configuração de um subsistema de ensino supletivo em expansão (DI PIERRO, 2005a, p. 1117).

É fato que as experiências coletivas são menos valorizadas na estrutura organizacional do CEEJA, em favorecimento ao atendimento individualizado. A Resolução SE 77/2011, no entanto, prevê em, seu artigo $4^{\circ}$, a oferta de trabalhos coletivos e aulas em grupo, como parte de sua organização curricular.

Os cursos referentes aos anos finais do Ensino Fundamental e ao Ensino Médio mantidos pelos CEEJAs terão, em cada nível de ensino, organização curricular abrangente de modo a contemplar todas as disciplinas que integram a Base Nacional Comum e mais a Língua Estrangeira Moderna da Parte Diversificada do Currículo, cujos conteúdos deverão ser desenvolvidos com metodologias e estratégias de ensino adequadas à característica do curso de presença flexível, mediante atendimento individualizado do aluno e oferta de trabalhos coletivos ou aulas em grupo (SÃO PAULO, 2011, art. $4^{\circ}$ ).

A Resolução SE 77/2011 mantém a mesma preocupação com o respeito ao ritmo de aprendizagem dos estudantes já existente nos CEES.

Observada a exigência do cumprimento da presença mensal e da realização das avaliações periódicas, a duração do intervalo de tempo que intermediará a data da matrícula, inicial ou em continuidade de estudos, e a(s) data(s) prevista(s) para a realização das avaliações finais dependerá, exclusivamente, da capacidade e do ritmo de aprendizagem do aluno, bem como de sua disponibilidade de tempo para estudar, de seu interesse, de suas necessidades e dos resultados alcançados (SÃO PAULO, 2011, art. $6^{\circ}$ ). 
Sobre os materiais didático-pedagógicos específicos disponibilizados para o estudo dos alunos, o documento assegura:

Os CEEJAs utilizarão materiais didático-pedagógicos específicos, a serem disponibilizados pela Secretaria da Educação, como referência básica para: I - o desenvolvimento dos conteúdos, competências e habilidades das disciplinas do Ensino Fundamental e Médio;

II - a elaboração de questões/itens que irão compor, para cada aluno ou grupo de alunos, as avaliações parciais e finais das disciplinas do curso;

III - subsidiar a diversificação das formas e oportunidades de avaliação, bem como a análise dos resultados alcançados (SÃO PAULO, 2011, art. $6^{\circ}$ ).

O material didático disponibilizado pela Secretaria de Educação, o EJA Mundo do Trabalho, adaptado à organização dos CEEJA, só foi disponibilizado para as escolas em meados de 2014, para os cursos de ensino fundamental, e em meados de 2015, para os cursos de ensino médio. O material composto pelos cadernos do estudante e vídeo-aulas de apoio é também disponibilizado abertamente na internet ${ }^{23}$.

Sobre os docentes, a Resolução SE 77/2011, define determinados critérios para nortear a análise do perfil dos candidatos ao credenciamento para atuar em um CEEJA:

$\S 1^{\circ}$ - O processo de credenciamento, de que trata o caput deste artigo, será realizado conjuntamente pela Diretoria de Ensino e pela direção do CEEJA, observando-se critérios que devem nortear a análise do perfil do docente/candidato, sob os seguintes aspectos:

1 - de comprometimento com a aprendizagem do aluno, demonstrado mediante:

- clima de acolhimento, equidade, confiança, solidariedade e respeito que caracterizam seu relacionamento com os alunos;

- alta expectativa quanto ao desenvolvimento cognitivo e à aprendizagem de todos os alunos;

- preocupação em avaliar e monitorar o processo de compreensão e apropriação dos conteúdos pelos alunos;

- diversidade de estratégias utilizadas para promover o desenvolvimento dos alunos;

2 - de responsabilidades profissionais, explicitadas pela:

- reflexão sistemática que faz de sua prática docente;

- forma como constrói suas relações com seus pares docentes e com os gestores da escola;

- participação em cursos de atualização e aperfeiçoamento profissional;

3 - de atributos pessoais sinalizados pelos índices de pontualidade, assiduidade, dedicação, envolvimento e participação nas atividades escolares (SÃO PAULO, 2011, art. 14º).

De acordo com Cunha e Teodoro (2015), com uma organização diferenciada, que não tem a rotina de sala de aula nem a dinâmica de uma escola regular, "os professores necessitam

\footnotetext{
${ }^{23}$ http://www.ejamundodotrabalho.sp.gov.br/ConteudoCEEJA.aspx
} 
rever a sua prática pedagógica, visto que o atendimento é individualizado e deve ser seguido o ritmo de aprendizagem de cada discente" (CUNHA e TEODORO, 2015, p. 03).

Neste sentido, ao analisar as práticas dos professores do CEEJA, os autores ressaltam a importância de levar em conta as vivências dos jovens e adultos que procuram retomar sua escolarização. A forma como os professores devem conduzi-los aos estudos, assim, precisam ser diferenciadas, a partir de alguns pressupostos.

O professor necessita incorporar a rotina de pesquisar e de se atualizar para organizar unidades de estudos e atividades que disponibilizará aos seus alunos, além de elaborar vários modelos de avaliações que aplicará durante o curso e conforme o ritmo de aprendizagem de cada indivíduo. (...) O Professor deve planejar atividades diferenciadas, como aulas coletivas, oficinas, palestras e visitas culturais, além de disponibilizar materiais e pesquisas de acordo com a avaliação diagnóstica e necessidades de aprendizagem de cada aluno (CUNHA e TEODORO, 2015, p. 07).

São funções da rotina pedagógica do professor de um CEEJA: a) orientação inicial sobre a organização curricular, o uso do material didático, unidades de estudo e atividades de avaliação; b) aplicação de avaliações parciais e finais c) orientação Individual para acompanhar o desenvolvimento do estudante, tirar dúvidas e disponibilizar novas unidades de estudo; d) planejamento e oferecimento de oficinas e atividades curriculares coletivas e presenciais com os alunos.

Os docentes do CEEJA até 2015 cumpriam uma jornada de 32 horas/aulas de atendimento aos alunos e mais 3 horas/aulas de ATPC, ou seja, todos os professores atuavam em jornada integral na escola, o que favorecia muito o desenvolvimento de atividades interdisciplinar e elevação do grau de comprometimento dos docentes com o projeto. No entanto, a Resolução n. 10 de 29 de janeiro de 2016 alterou o documento anterior, abrindo a possibilidade para professores atuarem nos CEEJA como composição de sua carga suplementar, isto é, em uma jornada menor e dividida entre outras escolas.

Esse painel histórico e organizacional melhor contextualiza o corpus de investigação descrito no capítulo posterior, que trata de todos os elementos da pesquisa de campo. 


\section{CAPÍtUlO 5 - A PESQUiSA DE CAMPO: DIÁlOGO COM O FENÔMENO OBSERVADO}

Este capítulo tem por objetivo descrever e refletir sobre os elementos centrais da pesquisa, como o processo de formulação do problema, a caracterização do corpus de investigação, a descrição do objeto e os aspectos metodológicos utilizados no processo de investigação. Além disso, o capítulo traz a análise dos dados obtidos e a discussão dos seus resultados.

Procuro promover neste capítulo uma reflexão acerca da metodologia escolhida, em termos de abordagem, tipologia, sujeitos envolvidos, instrumentos de coleta de dados e formas de análise. Com base em autores como Bogdan e Biklen (1994), Laville e Dionne (1999), Gil (2002), Ludke e André (2014), Pesce e Abreu (2013) teço considerações sobre as características da pesquisa qualitativa em educação, em especial o estudo de caso educacional, tipologia adotada nesta investigação.

Procuro também esmiuçar os critérios para seleção dos seis professores participantes da pesquisa. Dentro de um quadro de 27 docentes, escolhi como critério inicial a divisão em dois grupos: aqueles que implementaram a oficina planejada e aqueles que não o fizeram. Dentro destes grupos, optei por subdividi-los em áreas do conhecimento (linguagens e suas tecnologias, ciências humanas e suas tecnologias e ciências da natureza e suas tecnologias), a fim de observar a maior pluralidade de perspectivas possível. Além dos docentes, o professor coordenador que participou do planejamento e da execução do curso também foi entrevistado, a fim de obter mais dados sobre o processo e os resultados atingidos pela formação.

A delimitação do problema de pesquisa foi um processo árduo de busca por um questionamento que, ao mesmo tempo em que sintetiza o que objetivo investigar, abrange o universo de três grandes campos da pesquisa em educação: o campo das tecnologias aplicadas à educação, o campo da formação de professores e o campo da educação de jovens e adultos. Desta forma, pretendo descrever o processo reflexivo que me colocou diante do meu problema: se e como o curso em tela contribui para o repensar da prática docente, amparada na utilização críticas das TDIC, de modo a empoderar os professores, ao situar sua prática docente em uma perspectiva autoral?

A partir da compreensão da história do ensino supletivo e do CEEJA, descrita no capítulo anterior, dedico parte deste capítulo a descrever o Centro Estadual de Educação de Jovens e Adultos onde se desenvolveu o curso de formação continuada em serviço "Mídias Digitais na Educação de Jovens e Adultos" e onde atuam os docentes que compõem o quadro 
de sujeitos da pesquisa de campo. Trata-se de uma necessidade fundamental, na medida em que o CEEJA possui especificidades que precisam ser consideradas para clarificar o objetivo e as estratégias escolhidas para o curso de formação e o planejamento de oficinas.

Outra preocupação centrada neste capítulo é a de realizar um relato cuidadoso do curso de formação "Mídias Digitais na Educação de Jovens e Adultos", sua concepção e sua execução. A descrição analítica do processo de planejamento e dos cinco encontros que o compuseram é fundamental para compreensão do objeto. Também descrevo a bibliografia elencada como referencial teórico para o curso e as estratégias utilizadas para agregar riqueza aos debates e à construção do produto final: o plano de oficina a ser oferecida aos alunos, levando em conta as discussões com os pares, as características específicas do público da EJA e o uso pedagógico das TDIC.

O capítulo apresenta também os resultados obtidos por meio da análise de dados, tanto a análise documental do plano de curso, do projeto político-pedagógico do CEEJA e dos planos de oficinas, quanto à análise temática de conteúdo das entrevistas obtidas com os seis professores e um coordenador da escola. A análise é feita à luz do referencial teórico elencado nos quatro capítulos anteriores e nos documentos da Unesco (2009a; 2009b), que tratam dos Padrões de Competência em TIC para professores (ICT-CST).

Por fim, o capítulo traz a discussão dos resultados, em que aponto, a partir da análise de dados, as percepções sobre os limites e as contribuições do curso "Mídias Digitais na Educação de Jovens e Adultos” para o repensar da prática docente, amparada na utilização crítica das TDIC, de modo a empoderar os professores, ao situar sua prática docente em uma perspectiva autoral.

\subsection{Formulação do Problema}

O problema de pesquisa é verdadeiramente delimitado quando é formulada uma pergunta, ou um conjunto de perguntas, que a investigação pretende responder e cujas respostas se tornem relevantes (LUNA, 2009). Sua formulação é tão importante, que as demais decisões tomadas pelo pesquisador, como objeto, metodologia, métodos de coleta de dados, sujeitos de pesquisa, etc., são determinados por ela.

Luna (2009) considera fundamental para a formulação do problema de pesquisa a tarefa do pesquisador de destrinchar a realidade em tela, buscando destacar as respostas que gostaria de obter ou, pelo menos, indicar que aspectos do fenômeno a estudar ele julga necessário cercar. Este momento inicial do estudo de caso pode ser chamado de fase exploratória 
(LUDKE e ANDRÉ, 2014). Ao mergulhar no contexto do CEEJA e na percepção de que a formação de professores para o uso pedagógico das TDIC era uma demanda urgente, rapidamente percebi a necessidade de compreender se e como a formação contribui na maneira como o docente compreende o uso das TDIC em sua prática como o aspecto da realidade que pretendia investigar.

Este processo de delimitação assemelha-se a um funil: "no início há questões ou focos de interesse muito amplos, que no final se tornam mais diretos e específicos. O pesquisador vai precisando melhor esses focos à medida que o estudo se desenvolve" (LUDKE e ANDRÉ, 2014. p.14). Por esta razão, a abordagem qualitativa do tipo estudo de caso depende de uma fase exploratória, em que o pesquisador precisa se aproximar do tema e construir um corpus de pesquisa com o objetivo de definir melhor seu problema. Nesta fase, o pesquisador deve adotar uma postura aberta às novas descobertas, pois ela "é o momento de especificar as questões ou pontos críticos, de estabelecer os contatos iniciais para entrada em campo, de localizar os informantes e as fontes de dados necessárias para o estudo" (LUDKE e ANDRÉ, 2014. p.25). Ela é, portanto, fundamental para um delineamento mais preciso do objeto de investigação.

A partir da fase exploratória de aproximação da realidade, do trabalho intelectual de delimitação do problema e em diálogo permanente com minha orientadora, pude notar que não investigaria nesta pesquisa o impacto da formação nas práticas dos professores, porque não existia tempo, dentro da realidade de um projeto de pesquisa em nível de mestrado, destinado a uma investigação de tamanha amplitude. Desta forma, percebi que não se tratava de investigar o impacto nas práticas, mas se há contribuições do curso para o professor e como ele se dá. Diante do reduzido tempo e de minha reduzida experiência em pesquisa de campo, a compreensão desta contribuição fixou-se na reflexão do professor sobre suas práticas, isto é, no repensar docente sobre uso pedagógico das TDIC. Evidentemente, esta contribuição poderia ser mais profundamente percebida por meio da observação da transformação das práticas, o que a mim parece um indicativo da necessidade de dar prosseguimento a esta investigação em pesquisas futuras.

Este recorte vai ao encontro de um dos pressupostos da pesquisa qualitativa em educação definida por Bogdan e Biklen (1994): o significado que as pessoas dão às coisas e à sua vida são focos de atenção especial do pesquisador. Ao me dedicar à compreensão da influência do curso de formação para o repensar do professor sobre suas práticas, coloco-me aberto a encontrar pontos de vista distintos e leituras conflitantes de uma mesma realidade, 
mas mantendo como foco central o significado que os docentes atribuem ao uso das TDIC em suas práticas.

A delimitação do problema, já no momento de elaboração do projeto de pesquisa, foi delineada, partindo da preocupação com sua adequação ao tema. Isto porque, como transparece no primeiro capítulo desta dissertação, há poucas pesquisas no Brasil que aproximam os campos de investigação da formação de professores, do uso pedagógico das TDIC e da educação de jovens e adultos. Assim, a construção do problema teve que se preocupar com a proposição do diálogo com os três campos da pesquisa pedagógica, ao mesmo tempo em que se propôs a determinar claramente o que investigar e sob quais aspectos.

A dificuldade seguinte foi a da elaboração de uma pergunta que abarcasse de maneira clara e concisa a complexidade do problema, com conceitos bem determinados, que deixassem claros os aspectos sob os quais a investigação se debruçaria. Ao longo das inúmeras escritas e reescritas da questão-problema, alguns conceitos trabalhados nos capítulos teóricos desta dissertação foram adicionados, de modo a explicitar sob quais perspectivas a pesquisa partiria, como formação continuada em serviço, empoderamento e a perspectiva crítica do uso das TDIC. Deste modo, ao mesmo tempo em que delimita o recorte da realidade elencado, a questão também indica as premissas teóricas que sustentam o trabalho.

A questão-problema construída depois de demorado processo de reflexão, definida como a primeira de tantas escolhas que precisei fazer no desenvolvimento desta pesquisa, questiona: se e como o curso "Mídias Digitais na Educação de Jovens e Adultos" contribui para o repensar da prática docente, amparado pela utilização crítica das TDIC, de modo a empoderar os professores, ao situar sua prática em uma perspectiva autoral?

\subsection{Metodologia}

As abordagens qualitativas da pesquisa educacional visam contribuir para a produção de resultados cada vez mais suficientes para pensar as soluções mais adequadas aos problemas da educação básica no Brasil (LUDKE e ANDRÉ, 2014). A evolução da pesquisa em adequação nas últimas décadas permitiu, mais que o reconhecimento da legitimidade destas abordagens, o surgimento de novos métodos qualitativos que reforçaram a superação do paradigma positivista no campo.

A principal razão desta evolução está na compreensão do caráter de fluidez dinâmica dos estudos no campo da educação, na medida em que os pesquisadores passam a entender "o 
fenômeno educacional como situado dentro de um contexto social, por sua vez, inserido em uma realidade histórica, que sofre toda uma série de determinações” (LUDKE e ANDRÉ, 2014, p. 6). Além disso, a mutação da ideia de causalidade, reconhecendo a complexidade de uma teia quase inexorável de variáveis que agem no campo da educação é outro passo fundamental para a evolução das abordagens qualitativas da pesquisa educacional.

Um dos aspectos que define a pesquisa qualitativa, de acordo com Bogdan e Biklen (1994) é o contato direto do pesquisador com a situação estudada para obtenção de dados descritivos, isto é, uma pesquisa que enfatiza mais o processo do que o produto e se preocupa em retratar a perspectiva dos participantes. Para os autores, a pesquisa qualitativa tem o ambiente natural como sua fonte direta de dados e o pesquisador como seu principal instrumento. "Assim, as circunstâncias particulares em que determinado objeto se insere são essenciais para que se possa entendê-lo. Da mesma maneira as pessoas, os gestos, as palavras estudadas devem ser sempre referenciadas ao contexto onde aparecem" (LUDKE e ANDRÉ, 2014, p. 13).

Outra característica marcante da pesquisa qualitativa é o fato de os dados coletados serem predominantemente descritivos (BOGDAN e BIKLEN, 1994). Isto porque todos os dados da realidade são considerados importantes e cabe ao pesquisador atentar para o maior número de elementos possível na realidade estudada. Por esta razão, esta pesquisa firma-se em uma descrição minuciosa do curso de formação em tela, da sua concepção à sua execução, além do uso de mais de um instrumento de coleta de dados: entrevistas e análise documental do projeto político-pedagógico da escola, do plano do curso de formação em tela e dos planos de oficinas elaborados pelos professores ao final do curso de formação.

Neste sentido, o significado que as pessoas auferem às coisas e à sua vida é foco de atenção especial pelo pesquisador na pesquisa qualitativa, o que permite compreender o dinamismo interno da realidade, o que seria inacessível para o observador externo (LUDKE e ANDRÉ, 2014). Ao investigar a contribuição do curso de formação de professores para o uso pedagógico das TDIC, no contexto da educação de jovens e adultos, no repensar das práticas docentes, o foco é se e como estes professores, sujeitos desta pesquisa, compreendem esta contribuição.

Por fim, a abordagem qualitativa também se apoia em uma análise de dados que tende a seguir um processo indutivo. "Os pesquisadores não se preocupam em buscar evidências que comprovem hipóteses definidas antes do início dos estudos" (LUDKE e ANDRÉ, 2014, p. 14). As conclusões desta pesquisa, portanto, não visam validar nenhuma hipótese estabelecida 
a priori, mas compreender o significado que os docentes do CEEJA auferem ao curso de formação pelo qual passaram e a relação que, desde então, passaram a estabelecer com o uso pedagógico das TDIC, o que demanda uma inspeção nos dados obtidos em todo processo de pesquisa.

Entre as abordagens advindas do processo evolutivo da pesquisa qualitativa, surgiram a pesquisa participante, a pesquisa-ação, a pesquisa etnográfica e o estudo de caso, por exemplo. A princípio, ao lançar vistas ao objeto de estudo delimitado nesta pesquisa, a abordagem da pesquisa-ação pode parecer mais adequada. Entretanto, de acordo com Gil (2002), esta tipologia tem sido alvo de grandes controvérsias, na medida em que o envolvimento ativo do pesquisador e a ação, por parte das pessoas ou grupos envolvidos no problema podem comprometer a objetividade que caracterizam os procedimentos científicos. Ainda que haja envolvimento entre o autor da pesquisa e a realidade investigada, neste triplo papel coordenador-formador-pesquisador, o estudo de caso educacional foi entendido como o mais apropriado, exatamente por buscar garantir ao pesquisador o distanciamento necessário para a compreensão do objeto.

Além disso, na perspectiva de Stenhouse (apud ANDRÉ, 2005), que classifica os tipos de estudos de casos existentes, a presente investigação adequa-se ao que ele classifica como estudo de caso educacional, pois a preocupação central do pesquisador não é com a teoria social ou com o julgamento avaliativo do fenômeno, mas com a compreensão da ação educativa em si. No caso do presente estudo, a preocupação central do pesquisador incide sobre a compreensão da realidade do CEEJA investigado. Por meio do estudo de caso educacional, o pesquisador procura enriquecer o pensamento e o discurso dos educadores, pelo desenvolvimento de teoria educacional.

O estudo de caso visa estudar e compreender o que há de singular em uma dada realidade, podendo ser ou não similar a outras realidades, simples e específico, ou complexo e abstrato.

O interesse, portanto, incide naquilo que ele tem de único, de particular, mesmo que posteriormente venham a ficar evidentes certas semelhanças com outros casos ou situações. Quando queremos estudar algo singular, que tenha um valor em si mesmo, devemos escolher o estudo de caso (LUDKE e ANDRÉ, 2014, p. 20).

A realidade investigada no CEEJA em tela é singular e possui uma complexidade específica, mas pode se assemelhar à realidade de outros CEEJA, ou servir de parâmetros para 
as reflexões dos campos da formação de professores, da educação de jovens e adultos ou das pesquisas sobre o uso educacional das TDIC.

Para Ludke e André (2014), o estudo de caso possui algumas características fundamentais que são levadas em conta ao longo do processo desta pesquisa. São essas características que garantem seu potencial em educação. A primeira delas refere-se ao fato de o estudo de caso visar sempre à descoberta, isto é, "mesmo que o pesquisador parta de alguns pressupostos teóricos iniciais, ele procurará se manter constantemente atento a novos elementos que podem emergir como importantes durante o estudo" (LUDKE e ANDRÉ, 2014, p. 21). O desenrolar da pesquisa, portanto, poderá modificar os pressupostos nela estabelecidos, caso haja novos elementos que modifiquem aqueles formulados incialmente, desde que o pesquisador esteja aberto a novas respostas e novos questionamentos.

A segunda característica, segundo Ludke e André (2014), define que os estudos de caso enfatizam a interpretação em contexto. "Um princípio básico desse tipo de estudo é que, para uma apreensão mais completa do objeto, é preciso levar em conta o contexto em que ele se situa" (LUDKE e ANDRÉ, 2014, p. 21). A interpretação em contexto consubstancia-se como um dos elementos metodológicos basilares do presente estudo. A expectativa é que os dados obtidos ao longo desta pesquisa tragam contribuições para compreensão do objeto de estudo, relacionada à realidade específica do CEEJA investigado. A descrição da escola e do curso de formação em tela, ao longo deste capítulo, é minuciosa exatamente para que o leitor possa interpretar os resultados desta pesquisa, considerando todos os elementos do contex to em que o objeto se insere.

Os autores afirmam que a terceira característica dos estudos de caso é de buscar retratar a realidade de forma completa e profunda, isto é, levando em conta a multiplicidade de dimensões presentes na realidade investigada. "Esse tipo de abordagem enfatiza a complexidade natural das situações, evidenciando a inter-relação dos seus componentes" (LUDKE e ANDRÉ, 2014, p. 22). Por esta razão, esta pesquisa, para compreender a contribuição do curso de formação para o repensar docente sobre suas práticas, mediante integração das TDIC nas atividades educativas, focaliza as percepções positivas e negativas dos professores sobre o curso, os documentos dele resultantes, os relatos descritivos da formatação e execução do curso e das características da escola, bem como o projeto políticopedagógico do CEEJA. Essa miríade de ações tem por objetivo aproximar-se de toda a diversidade de dimensões presentes na realidade em estudo, como convém ao estudo de caso, enquanto investigação interpretativa em contexto. 
Os estudos de caso, de acordo com a quarta característica definida por Ludke e André (2014), usam uma variedade de fontes de informação. Por esta razão, os instrumentos de coletas desta pesquisa são, além da análise documental, a entrevista semiestruturada com docentes do CEEJA com características distintas, definidas previamente, com o objetivo de abranger a maior variedade de informantes possível. Desta forma, espera-se ser possível cruzar informações coletadas, a partir de diferentes instrumentos, enriquecendo as possibilidades de análise dos dados obtidos.

A quinta característica, de acordo com Ludke e André (2014), define que os estudos de caso revelam experiência vicária e permitem generalizações naturalísticas. A experiência relatada pelo pesquisador ao longo da pesquisa serve para que o leitor possa fazer suas generalizações naturalísticas, isto é, possa comparar o contexto apresentado na pesquisa com outras realidades. "Em lugar da pergunta: este caso é representativo de quê?, o leitor vai indagar: o que eu posso (ou não) aplicar deste caso na minha situação?” (LUDKE e ANDRÉ, 2014, p. 21). Para Alvez-Mazzoti (2006), "por meio de uma narrativa densa e viva, o pesquisador pode oferecer oportunidade para a experiência vicária, isto é, pode levar os leitores a associarem o que foi observado naquele caso a acontecimentos vividos por eles próprios em outros contextos" (ALVEZ-MAZZOTI, 2006, p. 648). Evidentemente, o curso de formação em serviço promovido no CEEJA em tela situa-se no contexto de uma dada realidade, mas os resultados observados são passíveis de serem transpostos a outras realidades da EJA e, eventualmente, a outros contextos de educação escolar.

A sexta característica, por sua vez, ressalta que estudos de caso procuram representar os diferentes e, por vezes, conflitantes pontos de vista presentes numa situação social. De acordo com Ludke e André (2014), a realidade pode ser compreendida sob diferentes pontos de vista e cabe a este tipo de abordagem revelar os pontos de convergência e divergência, além de posicionar o pesquisador diante da divergência. Este aspecto é levado em conta na presente investigação, na medida em que os sujeitos de pesquisa, descritos no item posterior, são selecionados de modo a considerar a diversidade de posicionamentos e possíveis pontos de vista conflitantes.

Por fim, a sétima característica descrita por Ludke e André (2014) define que os relatos do estudo de caso utilizam uma linguagem e uma forma mais acessível que os outros relatórios de pesquisa. Isto se deve às possibilidades mais diversas de coletas de dados e à preocupação com a transmissão clara, direta e bem articulada do caso, aproximando-o da experiência pessoal do leitor. "Pode-se dizer que o caso é construído durante o processo de 
estudo; ele só se materializa enquanto caso, no relatório final, onde fica evidente se ele se constitui realmente num estudo de caso" (LUDKE e ANDRÉ, 2014, p. 24).

Após a fase exploratória, momento no qual o problema de pesquisa foi delimitado e as diretrizes metodológicas desenhadas, a pesquisa inicia uma fase sistematizada de coleta de dados. Para esta fase foram elencados alguns instrumentos de coleta de dados: a) os seguintes documentos: projeto político-pedagógico do CEEJA em tela, plano de curso e planos de oficinas preparados pelos docentes, ao final do curso; b) entrevistas semiestruturadas junto a seis professores que participaram do curso "Mídias Digitais na Educação de Jovens e Adultos" no CEEJA investigado, escolhidos a partir de critérios apontados anteriormente e retomados adiante, e com o coordenador que colaborou com seu planejamento e execução.

A análise documental do projeto político-pedagógico do CEEJA visa comparar a percepção dos docentes sobre a experiência vivida no curso em tela com a ideia que institucionalmente o CEEJA faz do uso pedagógico das TDIC, na medida em que este documento, que deve ser coletivamente produzido, reflete a identidade da escola, sua visão e suas concepções pedagógicas.

A análise do plano de curso, por sua vez, objetiva levar ao leitor uma melhor compreensão do processo de concepção do curso, das suas referências teóricas e das estratégias adotadas pelo coordenador-formador-pesquisador.

Por fim, a análise documental do produto final do curso de formação, os planos de oficina, visa colaborar com a compreensão da contribuição do curso, na percepção dos professores, para suas práticas educativas que se valem das TDIC.

A entrevista consiste em um instrumento básico para a pesquisa qualitativa. Sua importância diante do presente objeto refere-se, especialmente, às possibilidades de interação com os sujeitos. Não há, na entrevista semiestruturada, de acordo com Ludke e André (2014), uma posição hierárquica tão rígida, como há na observação ou na aplicação de questionário, por exemplo. Segundo as autoras, há a possibilidade de criação de uma atmosfera de influência recíproca entre entrevistador e entrevistado.

É uma preocupação metodológica, que precisa ser levada em conta, o fato de o pesquisador ter atuado também como professor coordenador do CEEJA em estudo, mas em momento anterior ao da realização das entrevistas. Evidentemente, isto poderia influenciar determinadas respostas, mas não comprometer a pesquisa, se, enquanto pesquisador, eu puder deixar claro o momento em que exerço o papel de pesquisador e procurar construir com o entrevistado um clima de estímulo e aceitação mútua (LAVILLE e DIONNE, 1999). A 
construção das questões que compõem o roteiro de entrevista (APÊNDICE B) também levou este fato em consideração, procurando distanciar a figura do pesquisador, do formador e do professor coordenador. Daí a necessidade dos diálogos com a orientação da pesquisa, pela possibilidade de romper com os desdobramentos negativos para a pesquisa, oriundos do triplo papel social por mim assumido: coordenador, formador e pesquisador. A escolha do estudo de caso educacional como abordagem metodológica desta pesquisa visa também estabelecer o distanciamento entre os papéis, no momento de coleta de dados e buscar garantir objetividade na análise dos dados da pesquisa.

O roteiro da entrevista semiestruturada consiste em uma estrutura básica de questões, que tem a função de orientar o pesquisador, como um esquema básico. Não há necessidade, no entanto, de segui-lo rigidamente. No momento da entrevista, o pesquisador pode, fazendo uso de seu roteiro, escolher os caminhos que julgar mais adequados para obtenção de dados de seu informante. É fundamental também que haja respeito aos pressupostos éticos de grande respeito pelo entrevistado, pelo direito ao anonimato e por suas impressões, sua cultura, seus valores e opiniões (LAVILLE e DIONNE, 1999).

De acordo com Alberti (1989), a realização da entrevista deve seguir determinados cuidados, como códigos e padrões de conduta específicos; interesse comum, entre pesquisador e sujeito, pelo tema; criação de um clima de confiança e diálogo; a disponibilidade do entrevistador em escutar e intervir apropriadamente nas falas do entrevistado; e reconhecimento da singularidade de cada entrevista, de cada sujeito e visão de mundo, tomando o extremo cuidado em não induzir respostas. Além disso, o autor também destaca a relevância de o pesquisador considerar as circunstâncias em que a entrevista se realiza, como a adequação do local e do tempo disponível pelo entrevistado. As abordagens dos informantes se deram com ao menos uma semana de antecedência e as entrevistas foram todas realizadas em espaços do próprio CEEJA e em horários sugeridos pelos próprios entrevistados, de modo a evitar interferências.

\subsubsection{Sujeitos da Pesquisa}

Para a realização da coleta de dados por meio de entrevistas foram selecionados o professor coordenador que colaborou para o planejamento e a execução do curso "Mídias Digitais na Educação de Jovens e Adultos” e mais seis docentes do CEEJA.

Em obediência ao TCLE, que anuncia a garantia de confidencialidade das identidades dos entrevistados, os nomes dos sujeitos de pesquisa seguem identificados como o nome de 
alguns atuais representantes nacionais, estaduais e regionais dos Fóruns de EJA $^{24}$ em homenagem a este importante coletivo social de luta por educação para jovens e adultos no Brasil.

Sua seleção obedeceu aos seguintes critérios: a) ter participado dos encontros do curso de formação "Mídias Digitais na Educação de Jovens e Adultos", organizado e realizado nas ATPC do CEEJA investigado entre abril e maio de 2015; b) ter produzido, ao final do curso, o plano de oficina, prevendo a realização de uma oficina com uso de TDIC; c) três docentes que colocaram o plano de oficina em prática e outros três não o fizeram; d) ser de áreas distintas de conhecimento, de acordo com o quadro abaixo.

Quadro 3 - Critérios de seleção dos docentes entrevistados

\begin{tabular}{|c|c|c|c|c|}
\hline Docente & $\begin{array}{l}\text { Participação } \\
\text { no curso }\end{array}$ & $\begin{array}{c}\text { Elaboração } \\
\text { do Plano } \\
\text { de Oficina }\end{array}$ & $\begin{array}{c}\text { Execução do } \\
\text { Plano de Oficina }\end{array}$ & $\begin{array}{c}\text { Área de } \\
\text { Conhecimento }\end{array}$ \\
\hline 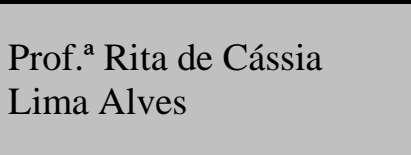 & Sim & Sim & Sim & $\begin{array}{l}\text { Ciências da } \\
\text { Natureza e suas } \\
\text { Tecnologias }\end{array}$ \\
\hline $\begin{array}{l}\text { Prof. a Cláudia Borges } \\
\text { Costa }\end{array}$ & Sim & Sim & Sim & $\begin{array}{l}\text { Ciências } \\
\text { Humanas e suas } \\
\text { Tecnologias } \\
\end{array}$ \\
\hline $\begin{array}{l}\text { Prof. a Silvana Mussalim } \\
\text { Guimarães }\end{array}$ & Sim & Sim & Sim & $\begin{array}{l}\text { Códigos e } \\
\text { Linguagens }\end{array}$ \\
\hline $\begin{array}{l}\text { Prof. a Maria Peregrino de } \\
\text { Fátima Rotta }\end{array}$ & Sim & Sim & Não & $\begin{array}{l}\text { Ciências da } \\
\text { Natureza e suas } \\
\text { Tecnologias }\end{array}$ \\
\hline $\begin{array}{l}\text { Prof. Luiz Roberto } \\
\text { Marighetti }\end{array}$ & Sim & Sim & Não & $\begin{array}{l}\text { Ciências } \\
\text { Humanas e suas } \\
\text { Tecnologias }\end{array}$ \\
\hline $\begin{array}{l}\text { Prof. Vinícius Xavier } \\
\text { Zammataro }\end{array}$ & Sim & Sim & Não & $\begin{array}{l}\text { Códigos e } \\
\text { Linguagens }\end{array}$ \\
\hline Prof. Renato Pontes & - & - & - & $\begin{array}{l}\text { Professor } \\
\text { Coordenador }\end{array}$ \\
\hline
\end{tabular}

Fonte: elaborado pelo pesquisador.

Entre o processo de definição dos critérios de seleção dos sujeitos de pesquisa e a realização das entrevistas, a Professora Maria teve sua condição alterada. Isto porque a atividade descrita em seu plano de oficina foi executada às vésperas da realização da entrevista. Sendo assim, na medida em que o encontro para coleta de dados já estava

${ }^{24}$ http://forumeja.org.br/ 
agendado e não havendo outro docente que se enquadrasse no critério estabelecido, a docente selecionada foi mantida.

A seleção dos sujeitos procurou abranger professores de diferentes áreas do conhecimento, divididos entre aqueles que executaram e aqueles que não executaram a oficina planejada. A partir deste critério, acredita-se que haja maior possibilidade de encontrar elementos que expliquem a contribuição do curso para a leitura crítica das TDIC na educação e para o repensar destes professores sobre suas práticas de uso das TDIC. Estes critérios procuram alcançar a validade e a representatividade de percepções, diante do corpus da pesquisa.

A professora de química Rita de Cássia atua no CEEJA há pouco mais de cinco anos. Possui licenciatura em química e em ciências físicas e biológicas. Ela é docente efetiva da rede estadual de ensino de São Paulo há cerca de 20 anos e atua também em uma escola privada da região. Ao longo dos encontros que compuseram o curso "Mídias Digitais na Educação de Jovens e Adultos", a docente participou ativamente das discussões, demonstrando proximidade com os textos sugeridos, além de maior abertura para o diálogo e a troca de experiências durante as ATPC. Ao final do curso, foi responsável por redigir, ao lado de outro professor de química, o plano de oficina sobre tabelas periódicas online e executou o planejado entre a segunda metade de 2015 e início de 2016.

Claudia Borges é professora de geografia e atende alunos do ensino fundamental II e do ensino médio do CEEJA há seis anos. Além de magistério, a docente possui licenciatura em geografia, licenciatura em pedagogia e pós-graduação em direito educacional. Na rede estadual a docente leciona há mais de vinte e cinco anos, como professora concursada, e também atua como gestora em escola privada. Cláudia, juntamente com o segundo professor da disciplina, elaborou o plano de oficina "Jogos Geográficos", em que propõe o trabalho com conceitos de cartografia e localização por meio do uso de games online. A oficina foi executada repetidas vezes nos últimos dois anos.

A professora Silvia leciona inglês no CEEJA, tanto para alunos do ensino fundamental como para estudantes do ensino médio, desde 2010 e é efetiva da rede estadual há quase duas décadas. Ela é licenciada em letras e possui graduação em psicologia, atuando nesta área paralelamente. Foi desta docente a ideia que culminou ao final do curso na elaboração do plano de oficina "Fan Fiction". A oficina proposta foi executada apenas uma vez, ao longo dos meses de abril e maio de 2016. 
Maria é docente de física do CEEJA há apenas três anos e efetiva da rede estadual desde 2014. É licenciada em física e atua como professora de matemática em escola privada do mesmo município do CEEJA. A docente participou da elaboração do plano de pesquisa que incluiu o uso de simulador virtual na oficina sobre astronomia. A oficina foi executada com este recurso apenas uma vez no ano de 2016.

O professor Luiz Roberto é graduado em ciências sociais (licenciatura e bacharelado) e atua como docente da rede estadual (categoria F) há mais de vinte anos. Possui longa experiência como professor coordenador e atua como professor de sociologia do CEEJA desde 2015. Apesar de ter participado da elaboração do plano de oficina, em que os docentes de história, filosofia e sociologia propuseram a criação de um blog de atividades da área de ciências humanas, Luiz Roberto não participou efetivamente da sua execução e não desenvolveu, desde a realização do curso, nenhuma oficina com uso das TDIC.

Vinícius é docente da rede estadual há quase trinta anos e atua também na rede municipal de ensino há cerca de vinte anos. É graduado em letras e há cerca de 6 anos é professor de língua portuguesa do ensino fundamental e do ensino médio do CEEJA. O docente assina o plano de oficina juntamente com a professora Silvia, no entanto, não se envolveu em sua execução até o momento.

O professor coordenador Renato é graduado em história e geografia e professor efetivo da rede estadual há quinze anos. Atuou como professor de geografia do CEEJA entre 2006 e 2014, quando assumiu a função de professor coordenador da escola, em que permanece até este momento. Renato colaborou efetivamente para a realização do curso, propondo dinâmicas, organizando material e discutindo comigo os pressupostos teóricos e as melhores estratégias de formação docente no contexto do CEEJA.

Os planos de oficinas citados até aqui são discutidos em seus pormenores na análise documental.

\subsection{Caracterização do Corpus: O CEEJA}

De acordo com Pesce e Abreu (2013), a partir das ideias de Andery et al. (2007), a Ciência situa-se como construção histórica e como prática social. Como tal, no momento da escolha metodológica, a pesquisa amparada nas premissas qualitativas vale-se da compreensão e da interpretação dos significados construídos pelo pesquisador. Daí a razão pela qual a pesquisa qualitativa valoriza sobremaneira o processo e o contexto de 
investigação. Tal entendimento esclarece o valor da caracterização do corpus de investigação, tecida a seguir.

Os Centros Estaduais de Educação de Jovens e Adultos (CEEJA) possuem, segundo a Secretaria de Educação do Estado de São Paulo, mais de 84 mil alunos matriculados em suas trinta e uma unidades. Atualmente, os municípios paulistas contemplados com unidades do CEEJA são Americana, Avaré, Barretos, Bauru, Bebedouro, Botucatu, Campinas (duas unidades), Caraguatatuba, Guarujá, Jaú, Lins, Marília, Mauá, Miracatu, Mogi das Cruzes, Penápolis, Piracicaba, Piraju, Poá, Praia Grande, Presidente Prudente, Registro, Ribeirão Preto, Santos (duas unidades), São José dos Campos, São Paulo, Sorocaba, Taubaté e Votorantim.

Entre as unidades de ensino, cinco concentram o maior número de matrículas. As escolas com maior número de matrículas ficam em São Paulo, Sorocaba, Bauru, Taubaté e Santos. Esses cinco locais concentram 37 mil jovens, adultos e idosos que têm idades entre 18 e 84 anos. Desde 2011, houve um avanço de 59,6\% no número de alunos, saindo de 52,6 mil em 2011 para os atuais 84 mil em 2015 (SECRETARIA DE EDUCAÇÃO DO ESTADO DE SÃO PAULO, 2015).

Para melhor compreensão das características dos CEEJA e das especificidades propostas por este modelo escolar, o capítulo anterior apresentou o panorama histórico e o modelo de organização desde a implantação das primeiras unidades do CEES. Em seguida, é fundamental debruçar-se sobre o CEEJA em tela, onde atuei como professor coordenador, onde atuam os docentes que serão sujeitos da pesquisa e onde foi desenvolvido o curso de formação em tela.

\subsubsection{O CEEJA, locus da pesquisa}

O Centro Estadual de Educação de Jovens e Adultos onde atuei como professor coordenador e onde foi realizado o curso de formação em tela é localizado em um município do litoral Sul de São Paulo e possuía até o final de 2015 um total de 3.237 alunos matriculados, sendo 1.017 estudantes do ensino fundamental II e 2.220 estudantes do ensino médio.

A escola localiza-se em um bairro central da cidade, próximo ao centro comercial, agências bancárias, escritórios, escolas, faculdades e aparelhos públicos como hospital, posto de saúde e delegacia. Sua localização é estratégica, na medida em que há nas proximidades circulação de ônibus vindos de todos os bairros e também de cidades vizinhas, o que facilita o acesso dos estudantes à escola. Os fundos da escola ficam em uma das avenidas mais 
movimentadas do centro comercial. Há no muro um enorme letreiro, com nome, telefone e site da escola, com o objetivo de torná-la ainda mais visível à população.

O prédio onde a escola funciona desde 2007 é cedido pela prefeitura do município. Nele funcionava até 2006 uma escola de educação infantil. Antes de 2007 o CEEJA era instalado em outro prédio da prefeitura, há poucos metros do endereço atual, onde hoje funciona um Centro "Paula Souza", que conta com uma Escola Técnica Estadual (ETEC) e uma Faculdade de Tecnologia (FATEC). O prédio atual sofreu poucas adaptações para se tornar um CEEJA. Ele conta hoje com 10 salas de aula, de diferentes dimensões, secretaria, direção, coordenação, sala de professores, cozinha, pátio e área externa.

A secretaria da escola localiza-se na entrada do prédio, onde há um guichê de atendimento e alguns bancos. É comum ver estes bancos lotados em dias de reunião inicial, quando alunos novos são recebidos por um dos coordenadores, para uma reunião sobre a metodologia e as regras da escola. Na secretaria trabalham a gerente de organização escolar, responsável pela secretaria, e outras três funcionárias. O fluxo de atendimentos na secretaria de um CEEJA é maior que em uma escola regular, porque a escola realiza matrícula ao longo de todo ano letivo. Além disso, os alunos devem ir à secretaria sempre que concluírem uma disciplina e pretenderem matricular-se em outra. Portanto, o horário de atendimento da secretaria estende-se por todo o horário de funcionamento da escola.

Sobre a secretaria há um segundo andar, onde uma ampla sala foi dividida em sala da direção, sala de coordenação e sala dos professores. Na sala da direção atuam a diretora e o vice-diretor. Ao lado, há um espaço onde trabalham os professores coordenadores e onde é também a sala dos professores, com computadores, arquivos, e armários com material pedagógico, banco de avaliações e acervo de livros. Trabalha nesta sala um professor readaptado cuja função é imprimir o grande volume de avaliações necessário para o funcionamento do CEEJA. Há também nesta sala uma grande mesa, onde acontecem algumas reuniões.

Ao lado da secretaria, a Sala 1 é o espaço mais bem equipado da escola. Trata-se de um ambiente reservado para oficinas, ATPC, reuniões iniciais e aplicação de avaliações de adaptação e reclassificação. Ela possui trinta carteiras estofadas, computador, projetor, sistema de som e ar condicionado. A maior parte das atividades pedagógicas coletivas acontece ali ou na Sala 6, que é também a sala de leitura e informática do CEEJA.

$\mathrm{Na}$ sala de leitura há um acervo de livros e DVD, oito computadores conectados à internet e quatro mesas, com quatro cadeiras cada, utilizadas pelos alunos para leitura e 
estudo. Trabalha nesta sala uma professora readaptada que oferece apoio aos alunos no uso dos computadores e na consulta ao acervo. Algumas oficinas, como o Círculo de Leitura, são realizados neste ambiente, que foi todo montado por iniciativa da própria escola entre 2014 e 2015. Quando não está sendo utilizada para oficinas e atividades pedagógicas coletivas, a sala fica disponível para alunos, professores e funcionários fazerem uso dos computadores e do acervo.

A Sala 2 é o espaço de atendimento da disciplina de Inglês, onde atuam dois professores. Na Sala 3, mais ampla, atuam dois professores de História e dois professores de Geografia. A Sala 4, onde até 2015 funcionava uma pequena sala de informática, é hoje o espaço de atendimento da disciplina de Sociologia, também com dois professores. No caminho até ela há um corredor com cerca de 10 prateleiras, onde fica armazenada uma quantidade grande material didático para os alunos. Na Sala 5 funciona o atendimento de Arte. Diferentemente das demais, nesta sala há uma mesa maior ao invés de carteiras, onde as duas professoras desenvolvem produções com os alunos. Na Sala 7 ocorre o atendimento da disciplina de Filosofia, também com dois docentes. As Salas 8, 9 e 10 são maiores. Na Sala 8 ocorre o atendimento em Língua Portuguesa, realizado por quatro professores, enquanto na sala 9 ocorre o atendimento de Matemática, com quatro professores, e Física, com dois professores. Na Sala 10, por fim, atendem dois professores de Química, uma professora de Ciências e dois professores de Biologia. Todas as salas do CEEJA, desde 2014, são climatizadas com aparelhos de ar condicionado.

No pátio há uma grande quantidade de carteiras, além de uma grande mesa onde muitos estudantes estudam ao longo do dia. Nele há também um palco, onde são realizados as palestras, apresentações de teatro ${ }^{25}$ e outros eventos organizados pela escola, além de banheiros e de uma cozinha, utilizada apenas por professores e funcionários. Cinco murais espalhados pelo pátio são utilizados para informações sobre horários, oficinas, eventos, cursos e exposição de trabalhos. Uma pequena sala contendo uma pia e materiais de laboratórios é usualmente utilizada para promoção de oficinas de química, física e ciências. Nos fundos do pátio há acesso a uma grande área externa, onde há um jardim e uma pequena horta mantida por alguns professores. Algumas oficinas também são realizadas neste espaço, quando há necessidade de realizá-la em área externa ou quando se objetiva estudar algum aspecto natural do jardim e da horta.

\footnotetext{
${ }^{25}$ A escola conta com um grupo de teatro formado por professores, alunos e ex-alunos, desde 2013.
} 
A escola conta com três funcionárias para a limpeza de todos os espaços e também para preparação da merenda, que devido à fluidez dos alunos, normalmente é uma mesa colocada no pátio com frutas, bolachas, suco, bebida láctea e, eventualmente, pão e margarina. $\mathrm{O}$ consumo destes alimentos ocorre ao longo de todo o dia. São, portanto, um total de vinte e sete docentes, dois professores readaptados atuando com a impressão de material e na sala de leitura, dois professores coordenadores, uma diretora, um vice-diretor, quatro funcionárias da secretaria e três funcionárias da limpeza.

Não há nenhuma determinação legal que estipule exatamente o horário de funcionamento dos CEEJA, apenas a determinação para que funcione no período da manhã, da tarde e da noite. Por opção da escola, o horário de funcionamento é de segunda a quintafeira, das $9 \mathrm{~h}$ às $22 \mathrm{~h}$, sem intervalo. Na sexta-feira a escola funciona das $9 \mathrm{~h}$ às $20 \mathrm{~h} 30$, havendo um intervalo no atendimento entre $13 \mathrm{~h} 10$ e $15 \mathrm{~h} 40$, quando ocorre a reunião de ATPC com todos os docentes.

O aluno do CEEJA possui perfil bastante diversificado do ponto de vista da faixa etária. Há grande volume de jovens com pouco mais de 18 anos, muitos na faixa dos 30 e 40 anos, assim como há estudantes de idade mais avançada. A escola não possui uma estatística consolidada sobre o perfil e faixa etária de seus alunos. Percebe-se uma presença maior de estudantes mulheres e um fluxo maior de estudantes entre segunda e quinta-feira, no período entre $17 \mathrm{~h}$ e $21 \mathrm{~h}$.

O tempo de frequência diária dos estudantes também é bastante variável. Há aqueles que ficam na escola por muitas horas, dedicando-se aos estudos nos espaços que o CEEJA disponibiliza, realizando avaliações e participando das oficinas. Outros vão ao CEEJA realizar apenas uma avaliação ou receber instrução de um professor e pouco tempo ficam no interior da escola. Da mesma forma, o prazo de conclusão dos estudos também varia, de acordo com o tempo que o aluno dedica aos estudos, a sua disponibilidade em frequentar a escola e, obviamente, também de acordo com seu desempenho nas avaliações parciais e finais.

\subsubsection{Curso de formação continuada em serviço centrada na escola: "Mídias Digitais na Educação de Jovens e Adultos".}

Diferentemente do que ocorre na maior parte das escolas da rede pública, o CEEJA, devido à sua estrutura de organização como um projeto de pasta da Secretaria Estadual de Educação, oferece à equipe docente e gestora a possibilidade de concentrar todos os professores em uma reunião única de ATPC. Em virtude do atendimento aos alunos ocorrer 
de forma individualizada, a partir das necessidades específicas de cada estudante e com flexibilidade de horário, ao professor do CEEJA são possibilitadas melhores condições de reflexão sobre suas práticas, preparação de material e de novas estratégias didáticas. A ATPC, por conta disso, é um tempo valorizado para atividades de formação e de reflexão sobre as necessidades específicas dos alunos adultos.

Ao apresentar a proposta do curso de formação, no início de abril de 2015, a maior parte dos professores revelou-se bastante interessada na iniciativa, manifestando-se de forma elogiosa. Alguns professores, especialmente aqueles que já fazem significativo uso das TDIC em suas práticas pedagógicas e cotidianas, mesmo sem manifestar-se, demonstraram menor interesse. Uma preocupação fundamental, então, foi a de esclarecer que a formação não se propunha a apresentar estratégias prontas ou a ensinar, como usar determinado equipamento ou software. Para além disso, a proposta formativa tinha quatro objetivos norteadores: a) mobilizar o corpo docente para a reflexão acerca das mídias digitais e suas implicações para a relação entre a escola e o conhecimento; b) discutir as implicações das mídias digitas, a partir de uma postura crítica de rejeição à perspectiva instrumental; c) refletir sobre as possibilidades de empoderamento, pela inclusão digital de pessoas adultas reinseridas no ambiente escolar por meio da EJA; d) elaborar projetos de oficinas e produção de material didático a partir do uso das TDIC, com a intenção de promover aproximação reflexiva entre os alunos e as mídias digitais.

Desta forma, procurei deixar claro que o objetivo da formação era mobilizar discussões, apresentar possibilidades novas de compreensão da relação entre as TDIC e a escola, refletir sobre o papel do professor neste processo e, por fim, planejar oficinas que mobilizem o uso das TDIC, reconhecendo assim a importância de aproximá-los da cultura digital. Como estratégia, os cinco encontros programados propunham a leitura de textos e vídeos seguida de debates em grupos de discussão. A proposta exigia dos professores a leitura prévia dos textos de referência, o que para aquela equipe era uma novidade e uma dificuldade, na medida em que parte significativa, 14 dos 27 docentes, atuava em outras escolas e, portanto, possuía extensa carga horária em sala de aula e pouco tempo para se dedicarem às leituras básicas da formação, ainda que os textos tenham sido disponibilizados com bastante antecedência.

O primeiro encontro, previsto para a primeira hora de ATPC de 10 de abril, teve como texto base o capítulo A Nova Relação com o Saber do livro Cibercultura, de Pierre Levy (1999). No decorrer da semana, quatro professores manifestaram satisfação na leitura do texto, o que me fez acreditar que as discussões seriam ricas e o diálogo sobre o texto seria 
enriquecedor, como de fato ocorreu. Iniciei o encontro apresentando mais uma vez o projeto do curso, as justificativas, os objetivos, o cronograma e a proposta de avaliação, que consistia na elaboração de planos de oficinas com uso das TDIC. Preocupei-me, em seguida, em deixar claro que não se tratava de um curso sobre como utilizar as TDIC na EJA, mas sobre algumas propostas de reflexão crítica sobre o tema, além da tentativa de mobilizá-los para ampliar as práticas da escola neste sentido. Falei também que o foco da formação deveria ser a ampliação das atividades com uso da sala de informática da escola, além de outras possibilidades que as TDIC podem oferecer e que as leituras deveriam servir para repensar as oficinas planejadas pelos professores para o próximo semestre.

Iniciei, desta forma, a exposição sobre o texto com a apresentação do autor e o conceito de cibercultura. Exibi dois vídeos curtos sobre o conceito e, em seguida, apresentei alguns slides com excertos do texto de Levy (1999), a fim de estimular a discussão acerca da nova relação da sociedade imersa na cultura digital com o saber. Expus as principais ideias do autor e busquei o tempo todo utilizar as práticas dos professores em oficinas como experiências bem-sucedidas. Quando trabalhei com o conceito de simulação, por exemplo, citei a prática do professor de Física, que utiliza um simulador nas oficinas sobre astronomia. Da mesma forma, quando falei acerca da possibilidade da cibercultura promover novos gêneros textuais, trouxe a discussão sobre a experiência de um dos professores de língua portuguesa, que promoveu uma oficina de micro contos, com base na linguagem da rede social Twitter.

Ao encerrar a exposição do texto e a discussão sobre as experiências práticas já realizadas por alguns professores da escola, a discussão seguiu de modo mais aberto. Um professor, por exemplo, manifestou bastante interesse na perspectiva trazida por Lévy (1999), mas disse não ver tamanha novidade, a não ser pela velocidade e pela quantidade de informação, na medida em que a leitura textual continua sendo a plataforma para aprendizagem e comunicação, mesmo na internet. Outra questão trazida para a problematização por outro professor abordou a crítica ao conceito de virtual, muitas vezes utilizado em oposição ao real.

Desta forma, na perspectiva de apontar para a necessidade de a escola se modernizar, outros professores teceram suas críticas à educação pública, considerando-a, de um modo geral, muito atrasada em relação às novidades trazidas pela cibercultura. A ideia de compreender o professor como um mobilizador e animador da inteligência coletiva, em oposição ao seu papel de detentor de todo conhecimento, também foi destacada como significativa por outros professores. Outros pontos ressaltados, ao redor dos quais as 
discussões caminharam, foram a ideia de a cibercultura colocar por terra a ideia de conhecimento totalizante; a visão distorcida sobre o uso das tecnologias como reprodução das mesmas práticas; a desmotivação para o uso das TDIC por problemas de infraestrutura e dificuldade em fazer uso da própria sala de informática das escolas; a necessidade de que as TDIC façam parte da formação de jovens e adultos, na medida em que seu domínio é hoje pré-requisito para colocações mais valorizadas no mercado de trabalho. Estas problematizações enriqueceram o debate, de modo que saímos do primeiro encontro bastante satisfeitos e motivados pelas reflexões coletivas daquela tarde.

O segundo encontro, ocorrido na ATPC de 17 de abril, teve por base o artigo Políticas públicas para inclusão digital nas escolas, de Maria Helena Bonilla (2010) e objetivou, de acordo com o programa de formação, proporcionar uma discussão sobre o papel central que a escola deveria assumir no processo de inclusão digital. Na preparação deste encontro, incluí a discussão de Paulo Freire sobre o conceito de empoderamento, com a finalidade de relacionar a ideia de inclusão digital com a emancipação dos sujeitos, como indivíduos e, sobretudo, como classe: diferencial do conceito freireano de empoderamento. Além disso, busquei apresentar questionamentos, relacionando os temas ao contexto específico da educação de jovens e adultos e do próprio CEEJA.

Iniciei uma breve explanação do texto em que tratei principalmente do conceito de inclusão digital. Na perspectiva dos autores, procurei utilizar o conceito de inclusão e de empoderamento em seu sentido político, de luta por direitos legítimos para o exercício da cidadania e de subversão de uma hierarquia de poder, que se dá entre o incluído e o excluído. Os professores demonstraram bastante interesse por esta perspectiva e rapidamente relacionaram isto com a ideia de educação libertadora de Paulo Freire. Após breve discussão, propus a divisão dos docentes em três grupos, para que discutissem entre eles as seguintes questões: 1. É preciso pensar em modelos de inclusão digital específicos para adultos ou reproduzir os programas e métodos da educação básica regular é o bastante? 2. As especificidades da educação de jovens e adultos demandam maneiras específicas de uso pedagógico das TDIC? 3. De que forma a inclusão digital de adultos com baixa escolarização pode efetivamente contribuir para que ele atue nas esferas da cidadania e na luta por direitos, potencializando, assim, seu empoderamento?

Cada grupo expôs suas reflexões, de modo que houve consenso em torno da necessidade de construir estratégias específicas para o uso das TDIC na educação de jovens e adultos, evitando, desta forma, a recorrência ao erro de infantilizar os estudantes com a 
reprodução de práticas pensadas para crianças e adolescentes. Da mesma forma, alguns professores manifestaram adesão à ideia de que a inclusão digital, se pensada como um direito, pode contribuir para o empoderamento, na acepção freireana, de modo que a promoção da inclusão digital em uma escola pública destinada a adultos, como o CEEJA, consistia em um ato de natureza política.

O terceiro encontro, ocorrido na ATPC de 24 de abril, tratou dos recursos educacionais abertos (REA) e do conceito de aprendizagem colaborativa. O texto selecionado para este dia foi o artigo Professores autores em rede, de Nelson Pretto (2012), que traz uma abordagem interessante sobre as possibilidades de os docentes integrarem-se em uma rede de colaboração e compartilhamento de experiências e REA. Recursos Educacionais Abertos (PRETTO, 2012) são materiais de ensino, aprendizado e pesquisa em qualquer suporte ou mídia, que estão sob domínio público, ou estão licenciados de maneira aberta, permitindo que sejam utilizados ou adaptados por terceiros. Os professores que fazem uso constante da sala de informática e fazem uso destas ferramentas expuseram suas experiências, como o professor de matemática, que faz uso de um software online que simula um supermercado e a professora de geografia, que faz uso de jogos digitais para o trabalho com localização e projeção cartográfica.

Ao refletir sobre as próprias práticas do CEEJA, por meio de discussão, chegamos à conclusão de que o material didático disponibilizado no site da escola para que os alunos possam se preparar para as avaliações pode ser considerado um REA e é resultado da colaboração de diferentes docentes, inclusive aqueles que já passaram pela escola ou cederam o material, para editoração das apostilas do CEEJA. Trata-se, portanto, do fruto de mixagem de diferentes materiais e de uma produção em beta perpétuo (MATTAR, 2013), isto é, está em constante adequação às necessidades dos professores e alunos da escola, além de ser disponibilizado gratuitamente.

Como atividade de pesquisa, recomendei que os docentes buscassem na internet diferentes recursos - sites, blogs, games, plataformas e softwares - que tratassem de temas ligados às suas disciplinas. Para além da compreensão do que são os REA, a atividade serviria para embasá-los no planejamento das oficinas com uso das TDIC, que elaborariam ao final do curso. Devido à escassez de tempo provocada por outras demandas para aquela tarde de ATPC, a atividade não foi desenvolvida por completo e recomendei que os docentes a realizassem ao longo dos dias que se seguiram até o próximo encontro. 
O quarto encontro, ocorrido no dia 8 de maio, destacou a questão das redes sociais e das mudanças originadas na internet a partir do surgimento da web $2.0^{26}$. Tendo por base dois capítulo do livro Web 2.0 e Redes Sociais na Educação, de João Mattar (2013). A discussão acerca deste texto foi importante para desconstruir, segundo falas de parte dos docentes, uma visão de internet ainda bastante vinculada à perspectiva da web 1.0 , em que o usuário é apenas um receptor de conteúdos produzidos por grandes portais. O blog, as wikis ${ }^{27}$, os $\mathrm{MOOC}^{28}$, as redes sociais, entre outras ferramentas da web 2.0, apesar de já estarem presentes na rede há cerca de uma década, puderam ser observados agora como possíveis ferramentas para o trabalho pedagógico.

A discussão derivada da explanação do texto tangenciou experiências conhecidas pelos docentes, principalmente o uso de blogs e de páginas nas redes sociais, principalmente no Facebook e no Twitter, com o objetivo de aproximar alunos e professores em torno da pesquisa e da produção colaborativa de conhecimento ou de compartilhar REA. Como atividade, pedi que os professores buscassem na internet blogs, comunidades e páginas nas redes sociais elaboradas por docentes, com objetivos pedagógicos.

As discussões que sucederam a atividade já apresentavam uma perspectiva diferente de uso das TDIC. Pela fala de parte dos docentes, pude notar que já compreendiam as tecnologias não apenas como novos recursos, mas como possibilidades de transformação de suas práticas, como meio por onde poderiam se concretizar novas formas de aprender.

O quinto e último encontro, ocorrido em 15 de maio, foi exclusivamente dedicado à produção de planos de oficinas. De acordo com a proposta inicial, os planos poderiam ser elaborados com foco em uma só disciplina ou poderiam ser interdisciplinares, desde que fizessem uso da sala de informática ou outros recursos adeptos à perspectiva e aos exemplos da formação "Mídias Digitais na Educação de Jovens e Adultos".

De modo geral, os planos de oficinas mostraram-se adequados à proposta de avaliação do curso de formação. Todos os docentes corresponderam à necessidade de articular conteúdos e habilidades dos currículos das disciplinas que lecionam com o uso das TDIC, a

\footnotetext{
${ }^{26}$ Segundo Tim O'Reilly (2005), o início deste século foi marcado por uma verdadeira reviravolta na organização do ciberespaço. O nascimento de uma nova era na internet, chamada de web 2.0, proporcionou transformações fundamentais para as redes de comunicação, o que, entre outras novidades, favoreceu o surgimento das redes sociais. A web 2.0 transformou ainda mais profundamente as inter-relações de comunicação e de produção de conhecimento. Trata-se de uma relação todos-todos e não mais unidirecional como outros veículos de comunicação, ou até mesmo a internet do passado.

${ }^{27}$ Wiki é uma coleção de muitas páginas interligadas em que cada uma delas pode ser visitada e editada por qualquer pessoa. De acordo com Mattar (2013), elas são a ferramenta que incorporam com ênfase o princípio da inteligência coletiva.

${ }^{28}$ MOOC é a sigla em inglês para Massive Open Online Courses, ou seja, Cursos Online Abertos e Massivos. Trata-se de cursos online, totalmente gratuitos, que objetivam a participação em larga escala através da Internet.
} 
fim de estimular o estudante adulto a fazer uso do computador. Mais importante que isso, esperava-se que o curso de formação tivesse conseguido mobilizar os professores para a importância de inovar suas práticas, a partir de uma perspectiva autoral, dialogando com a nova relação que a sociedade estabelece com o conhecimento, em um contexto de expansão do ciberespaço. E, para além, proporcionando aos estudantes jovens e adultos a possibilidade de aproximação maior com a cultura digital, como um passo inicial para a promoção do letramento e da inclusão digital, com vistas ao empoderamento freireano. Tais questões serão investigadas, junto aos sujeitos desta pesquisa, uma vez que se integram à questão-problema da presente pesquisa.

Para colaborar com a compreensão da dinâmica do curso de formação em tela, após sua descrição, é preciso realizar uma análise dos dados obtidos por meio da leitura do projeto político-pedagógico do CEEJA, do plano de curso e dos planos de oficinas produzidos pelos professores como resultado final da formação.

\subsection{Análise dos Dados}

A análise dos dados obtidos pautar na perspectiva da análise temática do conteúdo, de acordo com Bardin (1977). Esta análise, de acordo com Triviños (1987), pretende isolar os temas, divididos entre principais e secundários, abordados por um entrevistado, de acordo com o problema pesquisado, e comparar com outro, buscando o emparelhamento dos dados em convergências e as divergências, em seus discursos e percepções.

O procedimento da análise temática de conteúdo abrange a fase de pré-análise, em que a amostra do material utilizado deve seguir os seguintes princípios de exaustividade, para que não deixe nenhum dado de fora do processo, de representatividade, para que haja possibilidade de generalizar os resultados da análise, de homogeneidade, para que se evitem particularidades que impeçam a análise do conjunto e adequação, pois os documentos selecionados devem proporcionar as informações adequadas para alcançar os objetivos da pesquisa (BOGDAN e BIKLEN, 1994).

A análise documental e a análise temática de conteúdo, realizada a partir dos dados obtidos por meio de entrevistas, toma por base o Projeto Padrões de Competência em TIC para professores (ICT-CST), publicado pela Unesco em 2008, com o objetivo de apresentar “diretrizes específicas para o planejamento de programas educacionais e treinamento de professores para o desempenho de seu papel na formação de alunos com habilidades em tecnologia" (UNESCO, 2009b, p.01). O projeto apresenta, em diferentes documentos, uma 
descrição detalhada das habilidades específicas a serem adquiridas pelos professores. Segundo o projeto,

Os professores na ativa precisam adquirir a competência que lhes permitirá proporcionar a seus alunos oportunidades de aprendizagem com apoio da tecnologia. Estar preparado para utilizar a tecnologia e saber como ela pode dar suporte ao aprendizado são habilidades necessárias no repertório de qualquer profissional docente (UNESCO, 2009b, p. 01).

O objetivo geral do ICT-CST é, além de traçar um possível caminho para implementação do uso crítico das TDIC na reforma educacional, como melhoria da prática docente, contribuir também para um sistema de ensino de maior qualidade, que possa produzir cidadãos mais informados e uma força de trabalho altamente qualificada, assim, impulsionando o desenvolvimento econômico e social do país (UNESCO, 2009a).

O ICT-CST apresenta uma proposta de três padrões de competências em TDIC para os professores, tendo por base perspectivas alternativas e às vezes sobrepostas: A) Alfabetização em Tecnologia; B) Aprofundamento do Conhecimento; C) Criação de Conhecimento.

O quadro abaixo sintetiza as habilidades docentes sob cada um dos padrões de competência em uso de TDIC, especialmente nos aspectos considerados mais relevantes para a presente análise.

Quadro 4 - Síntese dos Padrões de Competência em TIC para Professores

\begin{tabular}{|c|c|}
\hline Abordagem & Habilidades Docentes \\
\hline \multirow{5}{*}{$\begin{array}{l}\text { A) Alfabetização em } \\
\text { Tecnologia }\end{array}$} & $\begin{array}{l}\text { Os docentes devem conseguir integrar ao currículo de suas } \\
\text { disciplinas o uso de tecnologia e os formatos de tecnologia para } \\
\text { alunos }\end{array}$ \\
\hline & $\begin{array}{l}\text { Os professores devem saber onde, como, quando (e quando não) } \\
\text { usar a tecnologia nas atividades em sala de aula e nas } \\
\text { apresentações. }\end{array}$ \\
\hline & $\begin{array}{l}\text { Os professores devem saber as operações básicas de equipamentos } \\
\text { e programas, como os programas de produtividade, navegador de } \\
\text { web, programas de apresentação e aplicativos de gestão. }\end{array}$ \\
\hline & $\begin{array}{l}\text { Os professores devem conseguir usar a tecnologia com toda a } \\
\text { turma, pequenos grupos e atividades individuais assegurando um } \\
\text { acesso igualitário. }\end{array}$ \\
\hline & $\begin{array}{l}\text { Os docentes devem ter habilidade tecnológica e conhecimento dos } \\
\text { recursos da web necessários para utilizar a tecnologia na aquisição } \\
\text { conhecimento pedagógico em apoio ao seu desenvolvimento } \\
\text { profissional. }\end{array}$ \\
\hline \multirow{2}{*}{$\begin{array}{l}\text { B) Aprofundamento do } \\
\text { Conhecimento }\end{array}$} & $\begin{array}{l}\text { Os professores devem ter profundo conhecimento de sua disciplina } \\
\text { e capacidade de aplicá-lo, com flexibilidade, a diversas situações. } \\
\text { Também devem ser capazes de criar situações-desafio complexas } \\
\text { como forma de avaliar o entendimento dos alunos. }\end{array}$ \\
\hline & $\begin{array}{l}\text { O professor assume o papel de estruturar as tarefas-desafio, } \\
\text { orientar o entendimento do aluno e dar apoio aos projetos } \\
\text { colaborativos. }\end{array}$ \\
\hline
\end{tabular}




\begin{tabular}{|c|c|}
\hline & $\begin{array}{l}\text { Os professores devem conhecer diversas ferramentas e aplicativos } \\
\text { específicos, em diversas situações baseadas em problemas e } \\
\text { projetos, além de serem capazes de usar os recursos de rede para } \\
\text { ajudar os alunos a cooperarem, acessarem informações e se } \\
\text { comunicarem com especialistas externos para analisar e solucionar } \\
\text { os problemas selecionados. }\end{array}$ \\
\hline & $\begin{array}{l}\text { Os docentes devem conseguir criar ambientes flexíveis de } \\
\text { aprendizagem em sala de aula, fazendo uso da tecnologia como } \\
\text { suporte à colaboração. }\end{array}$ \\
\hline & $\begin{array}{l}\text { Os docentes devem ter as habilidades necessárias para colaborar } \\
\text { com outros professores e fazer uso das redes para ter acesso às } \\
\text { informações, aos colegas e a especialistas externos em apoio a seu } \\
\text { próprio desenvolvimento profissional. }\end{array}$ \\
\hline \multirow{5}{*}{$\begin{array}{l}\text { C) Criação de } \\
\text { Conhecimento. }\end{array}$} & $\begin{array}{l}\text { Os professores devem ter conhecimento sobre os processos } \\
\text { complexos de pensamento cognitivo, saber como os alunos } \\
\text { aprendem e entender as dificuldades que os alunos encontram, } \\
\text { sabendo como apoiá-los }\end{array}$ \\
\hline & $\begin{array}{l}\text { O papel dos professores é modelar esses processos de forma clara, } \\
\text { estruturar as situações nas quais os alunos aplicam essas } \\
\text { habilidades cognitivas e ajudar os alunos a adquiri-las. }\end{array}$ \\
\hline & $\begin{array}{l}\text { Os professores devem ser capazes de elaborar comunidades de } \\
\text { conhecimento com base em TIC para dar apoio ao } \\
\text { desenvolvimento das habilidades dos alunos de criar conhecimento } \\
\text { e ao aprendizado contínuo e reflexivo. }\end{array}$ \\
\hline & $\begin{array}{l}\text { Os professores também deverão ser capazes de desempenhar um } \\
\text { papel de liderança no treinamento dos colegas e na criação e } \\
\text { implementação de uma visão de sua escola como uma comunidade } \\
\text { baseada na inovação e no aprendizado contínuo, enriquecida pelas } \\
\text { TIC. }\end{array}$ \\
\hline & $\begin{array}{l}\text { Os professores precisam ter a habilidade e a inclinação para } \\
\text { experimentar e aprender e usar constantemente as TIC para criar } \\
\text { comunidades profissionais de conhecimento }\end{array}$ \\
\hline
\end{tabular}

Elaborado pelo autor com base em UNESCO (2009a)

\section{A) Alfabetização em Tecnologia}

De acordo com os documentos da Unesco (2009a, 2009b), a abordagem da Alfabetização em Tecnologia possui como meta política preparar alunos, cidadãos e uma força de trabalho capaz de utilizar novas tecnologias para apoiar o desenvolvimento social e melhorar a produtividade econômica. Não se trata de uma meta que se propõe a mudar completamente a perspectiva de escola e muito menos a estrutura social, mas ao menos iniciar um movimento de integração das TDIC nas práticas pedagógicas.

Os estágios iniciais de desenvolvimento das competências docentes relacionadas à abordagem de alfabetização tecnológica incluem habilidades básicas em alfabetização digital, com capacidade de selecionar e utilizar os tutoriais educacionais não-personalizados, jogos, exercício e prática e conteúdo da web em laboratórios de informática ou em salas de aula limitadas para, assim, complementar os objetivos curriculares padrões, as abordagens de avaliação, planos de unidade e métodos didáticos de ensino. Os professores também devem conseguir usar as TIC para lidar com os 
dados em sala de aula e apoiar seu próprio desenvolvimento profissional (UNESCO, 2009b, p. 6).

Nesta perspectiva, o professor deve saber as operações básicas de equipamentos e programas, o que inclui basicamente o uso de programas básicos de gestão e produtividade e o uso de conteúdos da web. Devem saber onde, como e quando utilizar ou não utilizar a tecnologia em suas práticas, integrando, pouco a pouco, seu uso ao currículo escolar. Trata-se de uma perspectiva ainda instrumental de uso das TDIC, mas que pode anunciar um primeiro passo em direção ao uso crítico e criativo.

\section{B) Aprofundamento do Conhecimento}

A abordagem do Aprofundamento do Conhecimento está relacionada à concepção menos instrumental do uso das TDIC. Sua meta política está relacionada ao aumento da habilidade dos alunos, cidadãos e da força de trabalho para agregar valor à sociedade e à economia, aplicando o conhecimento das disciplinas escolares para solucionar problemas complexos. Esta perspectiva propõe uma mudança significativa nos processos de aprendizagem, agora mais centrados no aluno e pautados pela aprendizagem colaborativa e baseada em problemas e projetos.

As competências docentes relacionadas à abordagem de aprofundamento do
conhecimento incluem a capacidade de gerenciar informações, tarefas-
desafio e integração de ferramentas de programa abertas e aplicativos
específicos da matéria com os métodos de ensino concentrados no aluno e
projetos cooperativos, como forma de aprofundar o entendimento dos alunos
sobre os principais conceitos, assim como suas aplicações para solucionar
problemas complexos do mundo real. Para apoiar os projetos colaborativos,
os professores empregarão recursos de rede para ajudar os alunos a
cooperarem, acessarem informações e se comunicarem com especialistas
externos para analisar e solucionar os problemas selecionados. Os docentes
também devem ser capazes de usar as TIC para criar e monitorar os planos
de projeto individuais e de grupos de estudantes, assim como para ter acesso
a sites especializados e colaborar com outros professores que utilizam a rede
para acessar informações, em apoio a seu próprio desenvolvimento
profissional (UNESCO, 2009b, p. 7-8).

Neste sentido, esta abordagem propõe mais dinamismo à estrutura de sala de aula, com alunos trabalhando em grupos e com o professor orientando sua aprendizagem e valorizando projetos colaborativos. Nesta concepção, o professor assume um papel mais próximo daquele apresentado no capítulo dois por autores como Belloni (1998), Kenski (2003), Lopes (2005), Brito (2006), Porto (2006), Coll e Monereo (2010), Aquino e Bezerra (2011), Oliveira (2013) e Pesce (2013a). 


\section{C) Criação do Conhecimento}

A abordagem da Criação de Conhecimento é a mais ambiciosa e transformadora das três perspectivas trazidas pelos documentos (UNESCO, 2009a, 2009b), pois se concentra no permanente envolvimento da escola e do professor com a criação de conhecimento e com a inovação, atribuindo a eles o benefício da promoção de uma aprendizagem ao longo de toda a vida. Deste modo, esta perspectiva propõe uma concepção pedagógica inovadora e um currículo flexível, estabelecendo como metas as habilidades de solução de problemas, comunicação, colaboração, experimentação, pensamento crítico, expressão criativa e liberdade do estudante em estabelecer suas próprias metas e planos de aprendizagem.

Os professores que demonstram competência com a abordagem de criação de conhecimento poderão elaborar recursos e ambientes de aprendizagem baseados nas TIC, usarão as TIC para apoiar o desenvolvimento da criação de conhecimento e das habilidades de pensamento crítico dos alunos, apoiarão o aprendizado contínuo e reflexivo dos mesmos, além de criarem comunidades de conhecimento para os alunos e colegas. Eles também poderão desempenhar um papel de liderança no treinamento dos colegas e na criação e implementação de uma visão de sua escola como uma comunidade baseada na inovação e no aprendizado contínuo, enriquecida pelas TIC (UNESCO, 2009b, p. 9).

O professor capaz de criar conhecimento possui o papel de modelar e estruturar as situações nas quais os alunos aplicam essas habilidades e os ajuda a adquiri-las. A escola, desta forma, torna-se uma grande comunidade de aprendizagem em que os professores são alunos/mestres/produtores de conhecimento constantemente envolvidos na experimentação educacional e inovação (UNESCO, 2009a, 2009b). Esta visão mais arrojada sobre o uso pedagógico das TDIC está mais próxima de autores como Bonilla (2010), Pesce (2013a), Pretto (2012) e Okada Bujokas (2012), na medida em que vislumbram uma integração total das TDIC à inovação pedagógica, transformando profundamente o papel do professor, reconhecendo a necessidade de transformar o papel da escola e se opondo ao currículo engessado e centrado em conteúdos. Trata-se de uma visão que busca aproximar o currículo e das habilidades do estudante do século XXI, a partir de uma visão abrangente sobre as tecnologias.

As análises que seguem estão amparadas pelo arcabouço teórico tecido nos capítulos 2 , 3 e 4 desta dissertação. Os padrões de competências, apresentados pelo projeto ICT-CST, são também referenciais importantes para a presente análise, especialmente por serem validados por toda a importância conferida aos seus autores e à própria Unesco. 


\subsubsection{Análise Documental}

De acordo com Ludke e André (2014), a análise documental constitui uma técnica importante na pesquisa qualitativa, seja complementando informações obtidas por outras técnicas, seja desvelando aspectos novos de um tema ou problema. No caso do presente objeto, a análise documental será útil principalmente para compreender a relação do CEEJA em tela com dois aspectos abrangidos nesta pesquisa: a formação de professores, o uso educacional das TDIC e a concepção de educação de jovens e adultos.

\section{a) O Projeto Político-Pedagógico}

A fim de iniciar a análise dos dados obtidos junto ao objeto de pesquisa, a análise documental debruça-se sobre o projeto político-pedagógico deste CEEJA, com o objetivo de verificar a forma como, institucionalmente, a escola compreende três frentes fundamentais trazidas no decorrer deste relatório: a) a valorização das ATPC como um espaço de formação docente; b) o uso pedagógico das TDIC e a inclusão digital dos jovens e adultos estudantes da instituição; c) a concepção de EJA presente no documento.

O projeto político-pedagógico é um documento elaborado por toda a comunidade escolar que detalha objetivos, diretrizes e ações do processo educativo a ser desenvolvido na escola, expressando as exigências legais do sistema educacional, bem como as necessidades, propósitos e expectativas da comunidade escolar.

De acordo com Veiga (2000), o projeto político-pedagógico (PPP) revela as intenções da escola sobre suas concepções de educação e sociedade, revelando que toda ação pedagógica traz consigo uma dimensão política. Ele define-se, portanto, por seu projeto intencional e político. Além disso, o PPP também deve ser uma expressão dos anseios da comunidade escolar, implicando a efetiva participação de todos em todo seu processo de elaboração, implementação, acompanhamento e avaliação.

O PPP do CEEJA em tela passou por reelaboração ao longo do ano de 2015, tendo sua atual versão concluída cerca de seis meses após o encerramento da formação "Mídias Digitais na Educação de Jovens e Adultos”. Sendo assim, seria esperada maior influência da formação nas concepções definidas pelo documento sobre o uso pedagógico das TDIC e sobre as possibilidades de promoção da inclusão digital na escola. Esta suposição, no entanto, não se confirma, pois apesar de citada, a tecnologia restringe-se, no documento, apenas ao papel de instrumento de apoio às estratégias didáticas promovidas nas oficinas da escola. 
Já a concepção de ATPC como espaço de formação docente centrada na escola e a concepção de educação de jovens e adultos desvinculadas da perspectiva compensatória aspectos defendidos como pressupostos do curso de formação e do arcabouço teórico desta pesquisa - estão muito vivas no PPP da escola. Estes pressupostos, de acordo com o que sugere a análise do documento, relacionam-se com uma concepção de formação de professores defendida por Canário (1994) e Tardif (2014), por exemplo, centrada na escola e nas demandas dos professores diante do cotidiano específico da instituição. Da mesma forma, a concepção de EJA explícita no PPP relaciona-se com as posições defendidas por autores como Di Pierro (2005a) e Oliveira (2007), que, assim como outras referências, dialogam sobre a superação da visão compensatória nos capítulos teóricos desta pesquisa.

As ATPC são entendidas como espaço importante de formação pelo PPP, especialmente como uma forma de articulação pela equipe gestora entre as concepções de ensinoaprendizagem que permeiam a comunidade escolar, a concepção do currículo e a avaliação dos resultados obtidos pela escola.

A equipe gestora procura agir de modo à articular todos os segmentos no sentido de agregar as diferentes concepções e perspectivas do processo de ensino-aprendizagem na construção de uma proposta pedagógica comprometida com uma educação pública de qualidade e crítica, que reconheça seu papel transformador na vida de pessoas adultas que retomam seu processo de escolarização. Os espaços de ATPC, somados às reuniões de planejamento, replanejamento e reuniões administrativas são importantes para este processo de troca entre os segmentos, mediado pela equipe gestora. (CEEJA, 2015, p.15)

Desta forma, a ATPC, especialmente pelo formato adotado pela escola, em que todos os professores reúnem-se no mesmo dia e horário, favorece a troca de experiências e a própria consolidação da proposta pedagógica da escola. Além disso, o PPP faz referência à formação continuada de professores, especificando as atividades formativas realizadas no ano de 2014 e 2015, sejam elas centradas ou não na escola, conforme quadro abaixo:

Quadro 5 - Formações docentes no projeto político-pedagógico do CEEJA

\begin{tabular}{|l|l|}
\hline \multicolumn{1}{|c|}{ Formação } & \multicolumn{1}{c|}{ Formador } \\
\hline $\begin{array}{l}\text { Cursos de formação em EaD - Temas } \\
\text { diversos }\end{array}$ & $\begin{array}{l}\text { Escola de Formação e Aperfeiçoamento de } \\
\text { Professores (EFAP) }\end{array}$ \\
\hline Orientações Técnicas - Temas diversos & $\begin{array}{l}\text { Núcleo Pedagógico da Diretoria de Ensino da } \\
\text { Região São Vicente }\end{array}$ \\
\hline $\begin{array}{l}\text { Formação continuada em ATPC - "Mídias } \\
\text { Digitais na Educação de Jovens e Adultos" }\end{array}$ & Coordenação Pedagógica \\
\hline $\begin{array}{l}\text { Formação continuada em ATPC - Temas } \\
\text { diversos }\end{array}$ & Coordenação Pedagógica \\
\hline Formação para uso do material "EJA Mundo & Fundação do do Desenvolvimento \\
\hline
\end{tabular}


Como é possível observar, as formações continuadas pelas quais passaram os professores do CEEJA no ano de 2014 e 2015 diversificam-se, segundo o PPP, entre as formações em ATPC, orientações técnicas organizadas pela Diretoria Regional de Ensino à qual a escola vincula-se e formações em EaD, organizadas pela EFAP, além de uma formação específica, organizada pela FUNDAP, quando a escola implementava novo material didático modelado exclusivamente para os CEEJA e distribuídos a partir de 2014.

Segundo Canário (1994), a maior exigência que se coloca às entidades que pretendem realizar formações pensadas externamente às escolas é a adoção de uma atitude de grande humildade, de modo que se possa aprender com elas. Para este autor, não se trata de ensinar as escolas a serem criativas e inovadoras, mas de realizar com elas um processo de aprendizagem a partir do que elas produzem. Mas, para que isso seja possível, é necessário criar condições para dar a palavra às escolas e aprender a escutá-las. Assim, ao entender a formação centrada na escola como "um processo apropriativo de oportunidades educativas, vividas no quotidiano" (CANÁRIO, 1994, p. 32), o autor valoriza a importância da formação continuada de professores pensada dentro dos contextos específicos de cada escola, correspondendo às demandas dos professores e à própria cultura escolar, presente em um dado cotidiano.

Da mesma forma, a formação continuada em serviço centrada na escola também remete às concepções de Tardif (2014) sobre a formação docente, ao propor o aproveitamento dos saberes docentes construídos na experiência cotidiana para dentro dos espaços formativos das escolas.

O PPP do CEEJA não faz outras referências ao processo de formação docente e às ATPC. Em análise, o trecho que se refere às ATPC sugere que a escola o compreende como um espaço formativo, apesar de não definir maiores detalhes. Porém, não há no documento elementos suficientes para afirmar com precisão se estas formações se fundamentam em uma perspectiva crítica de formação docente e se valorizam o compartilhamento dos saberes experienciais entre os professores.

O uso pedagógico das TDIC é citado no PPP da escola apenas em uma breve passagem. Ao descrever a estratégia de combinação entre o ensino individualizado e o desenvolvimento de oficinas coletivas, o documento considera as tecnologias digitais como parte das possíveis estratégias didáticas para sua promoção. 
As oficinas fazem parte do currículo da escola e são planejadas pela equipe pedagógica com o objetivo de oferecer, através de estratégias didáticas diferenciadas, complemento para as aprendizagens realizadas através das orientações individuais. Elas podem fazer uso de estratégias com apoio das tecnologias digitais da informação e da comunicação, fazer uso de parcerias para palestras e eventos pedagógicos ou até serem realizadas fora da escola na forma de estudo do meio dirigido. (CEEJA, 2015, p. 6)

Ao tratar o uso das TDIC apenas como um apoio às estratégias das oficinas, o trecho revela uma visão ainda limitada sobre a relação entre a cultura digital e o conhecimento. $\mathrm{O}$ tema não é tratado pelo PPP levando-se em conta a potencialidade transformadora das TDIC diante da educação tradicional, especialmente no contexto da EJA. O documento não contempla, desta forma, as possibilidades de produção de conteúdos, de colaboração, de autoria e coautoria dos sujeitos no mundo digital, integrando jovens e adultos na cultura da web 2.0, como defende Bonilla (2010).

Da mesma forma, ao considerar as TDIC como apoio para estratégias didáticas, o PPP não leva em conta a necessidade de reflexão crítica sobre elas, conforme sugere Pesce (2013a); isto é, não pressupõe que as TDIC podem promover a emancipação dos sujeitos e da coletividade e, aparentemente, apenas reproduz as práticas pedagógicas tradicionais, mas com nova roupagem (KENSKI, 2003). Portanto, dentro do que sugere o documento, a escola perderia a possibilidade de fortalecer os espaços escolares como espaços de inclusão digital (SORJ e GUEDES, 2005).

É válido posicionar a visão que o PPP explicita sobre o uso pedagógico das TDIC, de acordo com o ICT-CST (UNESCO, 2009a, 2009b). Por sugerir o uso de tecnologias como instrumentos de apoio às práticas docentes é possível identificar uma perspectiva próxima da abordagem da Alfabetização em Tecnologia, isto é, a visão mais incipiente entre os padrões de competências em TDIC (UNESCO, 2009a).

A concepção de educação de jovens e adultos, presente no PPP em análise, contudo, aproxima-se mais do pressuposto pensado, tanto para o curso "Mídias Digitais na Educação de Jovens e Adultos", quanto para o referencial teórico do campo da EJA escolhido, inclusive como embasamento teórico desta pesquisa. A perspectiva da educação ao longo da vida e da oposição ao paradigma compensatório sustenta a argumentação de todo o PPP e perpassa diversas passagens de seu texto.

A concepção de educação de jovens e adultos no qual esta instituição se baseia parte da refutação da perspectiva compensatória desta modalidade de ensino. A EJA, muito mais do que repor conteúdos perdidos pelo fato do aluno ter passado um período fora da escola, deve procurar apresentar uma proposta de formação adequada ao seu público, evitando simplesmente 
reproduzir as práticas da educação básica regular. Compreende-se que a EJA deve pensar em uma formação de adultos ligada ao mundo do trabalho, mas fundamentada em uma perspectiva crítica de valorização da cidadania e defesa dos direitos humanos. (CEEJA, 2015, p.5)

Esta visão vai ao encontro das críticas apresentadas por Di Pierro (2005a), que define as políticas de EJA como estratégias compensatórias, que impedem a modalidade de valorizar suas especificidades do currículo, da formação de professores e do material didático, por exemplo, nutrindo visões preconceituosas que subestimam e infantilizam os alunos adultos. Ao se opor a esta visão, o documento também faz uma defesa do paradigma da educação ao longo da vida:

A educação de jovens e adultos é compreendida pela proposta pedagógica da escola a partir de uma perspectiva não compensatória, na medida em que o objetivo principal não é oferecer apenas a aprendizagem que estes alunos não obtiveram quando crianças e adolescentes, mas sim, colaborar com seu processo de formação ao longo da vida, cujo objetivo é promover a emancipação dos sujeitos para o exercício da cidadania plena. (CEEJA, 2015, p. 9)

A educação ao longo da vida, conforme discussão proposta no capítulo 3 é um conceito em construção e se insere em um campo de disputa entre forças oriundas da educação popular, adepta da visão emancipadora de educação de jovens e adultos, e forças que se apropriam do termo para tratar de uma formação vinculada às mudanças das condições da sociedade do trabalho, conforme discutem Alheit e Dausien (2006) e Lima (2007).

O texto do PPP deixa claro, no entanto, um posicionamento em favor de uma formação ao longo da vida, preocupada em promover emancipação dos sujeitos e contribuir para o exercício da cidadania plena. Desta forma, assume-se politicamente como parte de um projeto progressista, na contramão da concepção historicamente predominante de EJA voltada à racionalidade instrumental de capacitação para o mercado de trabalho e reposição de aprendizagens perdidas no passado dos sujeitos.

O sentido dado à perspectiva de formação ao longo da vida e a preocupação com a emancipação dos sujeitos e com sua formação para o pleno exercício da cidadania aproximam-se, inclusive, das concepções de Freire e Shor (1986), em especial do conceito de empoderamento, também presente no capítulo 3. O documento sugere uma EJA voltada para a conquista da autonomia e com vistas à promoção da transformação cultural dos sujeitos e grupos sociais formados por estudantes adultos em processo de retomada de sua escolarização. 
Há, portanto, uma relação quase uníssona entre os pressupostos teóricos trabalhados nesta pesquisa e o documento, no que se refere à concepção de educação de jovens e adultos e à formação continuada de professores centrada na escola, o que não ocorre quanto à abordagem do uso pedagógico das TDIC.

A análise documental do PPP contribui, em síntese, para compreender que, mesmo tendo sido concebido após a conclusão do curso de formação investigado, foi pouco influenciado pelas proposições de uso pedagógico das TDIC e inclusão digital que a formação promoveu. Mais adiante verifica-se em que medida esta formação impactou significativamente na maneira como o professor deste CEEJA pensa as TDIC em suas práticas.

\section{b) O Plano de Curso}

O plano de curso da formação "Mídias Digitais na Educação de Jovens e Adultos" (ANEXO A) foi elaborado no início de 2015 por mim e por outro professor coordenador com quem dividia a função de coordenar a equipe docente e preparar as ATPC. A idealização do curso de formação, como já dito, ocorreu devido a uma conjunção de fatores que se coadunam com o papel de coordenador-formador-pesquisador do campo das TDIC e da EJA: a) enquanto coordenador, motivou-me a percepção do reduzido uso das TDIC nas oficinas e demais práticas pedagógicas do CEEJA, ainda que a escola tenha uma infraestrutura tecnológica razoável, como computadores, internet banda larga e projetores multimídia; b) enquanto formador, motivei-me diante da possibilidade de intervir no olhar dos docentes diante das tecnologias, acreditando que o referencial teórico e as trocas de experiências que planejava realizar seriam capazes de promover um repensar sobre suas práticas; c) como pesquisador, motivou-me promover um curso que seria investigado com a objetividade de um estudo de caso, procurando, tanto quanto possível, exercer o duplo papel, de formador e de pesquisador, com o necessário distanciamento, em relação ao fenômeno observado.

O documento destaca em sua justificativa quatro pontos fundamentais: a) o foco nas especificidades da educação de jovens e adultos; b) a articulação com o projeto políticopedagógico da escola; c) o uso das ATPC como um espaço formativo; d) a demanda dos próprios professores para a realização deste curso. A justificativa ainda ressalta a maior oportunidade em promover formação no contexto desta escola, devido à presença obrigatória de todos os docentes no mesmo horário de ATPC. Neste ponto, o plano alinha-se ao PPP e à percepção de Canário (1994), por exemplo, ao valorizar o contexto escolar como o centro do processo formativo e ao observar as demandas docentes na formulação do curso. 
Em outro item do documento, os objetivos traçados no plano relacionam-se à mobilização dos docentes para iniciar ou aprimorar o uso pedagógico das TDIC. Além disso, o trecho também aponta para o objetivo de discutir as implicações das mídias digitas, a partir de uma postura crítica de rejeição à perspectiva instrumental (BELLONI,1998; PRETTO e ASSIS, 2008, PESCE, 2013a) e refletir sobre as possibilidades de empoderamento (FREIRE e SHOR, 1986; BAQUERO, 2012), por meio da inclusão digital de pessoas adultas reinseridas pela EJA no ambiente escolar (SORJ e GUEDES, 2005; BONILLA, 2010; BUZATO, 2010). Por fim, o documento também define, como objetivo final, a elaboração de planos de oficinas, analisados adiante, ou produção de material didático a partir do uso das TDIC, com a intenção de promover a aproximação reflexiva entre os alunos, os professores e as mídias digitais.

Os termos utilizados nos objetivos do plano "mobilizar", "refletir" e "discutir" revelam a intenção em promover uma formação centrada na perspectiva dialógica (FREIRE, 2001). O documento define como estratégias para a execução do curso grupos de discussão, leitura e discussão dos textos previamente indicados e a exibição de vídeos selecionados a priori, para sensibilizar e estimular o debate.

O documento enuncia quatro tópicos programáticos, para as discussões no curso de formação: a) Cibercultura e Mídias Digitais (LÉVY, 1999); b) Empoderamento Freireano e Inclusão Digital (PESCE, 2013a; BONILLA, 2010) c) Recursos Educacionais Abertos e Aprendizagem Colaborativa (PRETTO, 2012); d) Redes Sociais e Inteligência Coletiva (MATTAR, 2013). Para cada tópico foi indicado para leitura um texto de referência, que mobilizou a dinâmica de discussões do grupo, conforme descrição em tópico anterior. Como visto, a bibliografia básica que referenciou o curso de formação assemelha-se à contemplada no embasamento teórico desta pesquisa, pois se adequa aos pressupostos do curso de formação, elencados já na introdução deste relatório:

a) O uso pedagógico das TDIC, para que ofereça a possibilidade de contribuir para a inclusão digital e para o empoderamento dos sujeitos (na acepção freireana), precisa ser compreendido a partir de uma perspectiva não instrumental.

b) A formação crítico-reflexiva de professores precisa compreender a escola como seu locus privilegiado, para que possa efetivamente situar os professores em uma perspectiva autoral.

c) A educação de jovens e adultos deve ser compreendida a partir de uma perspectiva não compensatória e, portanto, ligada às noções de formação ao longo da vida e voltada para a emancipação dos grupos sociais. 
O encontro final, de acordo com o plano, tem como objetivo sintetizar a discussão e, separados em grupos de acordo com a área do conhecimento ou disciplina em que lecionam, os professores deveriam elaborar um plano de oficina que é analisado a seguir.

É possível situar o documento de acordo com os padrões de competência em TDIC para docentes (ICT-CST) estabelecidos pela Unesco (2009a, 2009b). O plano de curso parece posicionar-se na passagem entre a abordagem do Aprofundamento do Conhecimento e a Criação de Conhecimento. Isto porque trata do uso das TDIC em uma perspectiva de transformação do papel do professor (LEVY, 1999; BONILLA, 2010), de transformação social, por meio do empoderamento (PESCE, 2013a) e de uso inovador e colaborativo das TDIC (PRETTO, 2012; MATTAR, 2013).

Apesar desta correlação, no momento em que o plano de curso foi elaborado, as diretrizes estabelecidas pelos documentos da Unesco não faziam parte dos referenciais que direcionaram sua construção.

\section{c) Os Planos de Oficinas}

Para elaboração dos planos de oficina, após o último encontro da formação "Mídias Digitais na Educação de Jovens e Adultos”, os docentes do CEEJA receberam um formulário padrão utilizado pela escola na formulação de propostas de atividades coletivas. Este formulário estabelece alguns itens para o plano: a) título; b) duração; c) resumo; d) objetivos; e) recursos e requisitos; f) avaliação; g) descrição das etapas (sequência didática); e h) referências.

Foram entregues sete planos de oficinas ao término da formação. Todos eles, de alguma forma, abrangem temas, estratégias e concepções discutidas na formação. A seguir, a análise de cada plano pretende avaliar se eles convergem com o pressuposto do curso de formação, estabelecidos por meio do plano de curso analisado no item anterior, e com os pressupostos teóricos e de análise. O quadro abaixo procura sintetizar os planos de oficinas produzidos pelos docentes, como resultado da ação formativa.

Quadro 6 - Síntese dos planos de oficinas elaborados pelos professores

\begin{tabular}{|l|l|l|}
\hline \multicolumn{1}{|c|}{ Disciplina(s) } & \multicolumn{1}{|c|}{ Título } & \multicolumn{1}{c|}{ Breve Descrição } \\
\hline $\begin{array}{l}\text { Inglês, L. } \\
\text { Portuguesa e } \\
\text { Arte }\end{array}$ & FanFiction & $\begin{array}{l}\text { A oficina propõe a produção de conto escrito } \\
\text { colaborativamente por professores e alunos através de } \\
\text { plataforma digital dedicada à fan fiction. }\end{array}$ \\
\hline $\begin{array}{l}\text { História, } \\
\text { Filosofia e } \\
\text { Sociologia }\end{array}$ & $\begin{array}{l}\text { Blog de Ciências } \\
\text { Humanas }\end{array}$ & $\begin{array}{l}\text { Construção de blog com o objetivo de compartilhar } \\
\text { textos, vídeos, notícias, e realizar pesquisas de interesse } \\
\text { com os alunos das disciplinas de história, filosofia e } \\
\text { sociologia, além de publicar materiais produzidos pelos }\end{array}$ \\
\hline
\end{tabular}




\begin{tabular}{|l|l|l|}
\hline & & próprios estudantes nas oficinas. \\
\hline Geografia & Jogos Geográficos & $\begin{array}{l}\text { A oficina trabalha com conceitos de cartografia e } \\
\text { localização por meio do uso de games online como } \\
\text { forma de fixar conhecimentos e faz uso de avaliação } \\
\text { online por meio de uma plataforma específica. }\end{array}$ \\
\hline Matemática & $\begin{array}{l}\text { A Matemática vai } \\
\text { ao Supermercado }\end{array}$ & $\begin{array}{l}\text { A oficina trabalha operações matemáticas e conceitos } \\
\text { de matemática financeira a partir de experiência em que } \\
\text { aluno realiza suas compras em um supermercado } \\
\text { virtual. }\end{array}$ \\
\hline $\begin{array}{l}\text { Química e } \\
\text { Ciências }\end{array}$ & Tabela Periódica & $\begin{array}{l}\text { A oficina procura apresentar aos alunos os elementos da } \\
\text { tabela periódica por meio de uma plataforma dinâmica, } \\
\text { em que vídeos e textos interagem com o estudante na } \\
\text { descoberta das características de cada elemento. }\end{array}$ \\
\hline Biologia & $\begin{array}{l}\text { As tecnologias } \\
\text { como ferramentas } \\
\text { de pesquisa da da de } \\
\text { Biologia }\end{array}$ & $\begin{array}{l}\text { A oficina procura apresentar aos alunos estratégias de } \\
\text { desquisa na internet por meio da plataforma Google, a } \\
\text { fim de municiar o aluno acerca da forma mais adequada } \\
\text { de encontrar as informações que procura em sites } \\
\text { confiáveis. }\end{array}$ \\
\hline Física & $\begin{array}{l}\text { Astronomia } \\
\text { A oficina faz uso de simuladores do espaço que permite } \\
\text { ao estudante viajar por diferentes sistemas e } \\
\text { constelações, aproximando-o, assim, do que se conhece } \\
\text { hoje sobre astronomia. }\end{array}$ \\
\hline
\end{tabular}

Fonte: sistematizado pelo pesquisador, a partir dos planos de oficinas dos professores

Os professores de Língua Portuguesa, Inglês e Arte desenvolveram um plano de oficina intitulado "Fanfiction". O termo, ou sua abreviatura Fanfic, designa a ficção feita por fãs, sem caráter comercial ou lucrativo, a partir de uma determinada história criada por terceiros. A proposta trazida pelo documento, em resumo, propõe que os alunos produzam coletivamente um conto iniciado pelos professores, com base em alguma famosa obra de ficção não especificada no plano. Os docentes apontam como objetivo da oficina apresentar e aproximar os estudantes do gênero textual, exercitando a leitura, a escrita e a produção colaborativa. O plano de oficina definiu o site Fanfics Brasil ${ }^{29}$ como ferramenta para a produção do texto e propôs que os alunos fossem convidados a realizar a leitura e a continuar a produção do conto, por meio do acesso à plataforma. $\mathrm{O}$ conto acabado seria publicado no site da escola, para que todos os envolvidos e a comunidade pudessem ter acesso à sua leitura.

É possível afirmar que o plano elaborado pelos professores de Língua Portuguesa, Inglês e Arte enquadra-se no padrão de competências do Aprofundamento do Conhecimento, na medida em que é perpassado por uma perspectiva autoral e de aprendizagem colaborativa, conforme Unesco (2009a; 2009b). O documento demonstra, também, que os professores de

${ }^{29}$ http://fanfics.com.br/ 
Língua Portuguesa, Inglês e Arte planejaram uma oficina de acordo com os pressupostos do curso, especialmente, devido a três aspectos:

a) a proposta de produção colaborativa está de acordo com as proposições trazidas por Pretto (2012) e Mattar (2013), por exemplo, que valorizam as dinâmicas de autoria do professor e do educando no contexto da cibercultura e web 2.0;

b) a iniciativa também valoriza as individualidades do aluno da EJA e o coloca em um contexto de aprendizagem inovadora, diferente de experiências pedagógicas do seu passado escolar;

c) ao aproximar o aluno do computador, considerando que parte significativa dos estudantes do CEEJA não faz uso constante do computador, os professores mobilizam esforços para que os alunos frequentem a sala de informática e ponham de fato a mão no mouse e no teclado, para contribuir com a produção do conto.

O grupo de professores das disciplinas de História, Filosofia e Sociologia produziu um plano de oficina que propõe a construção de um blog, com objetivo de compartilhar textos, vídeos, notícias e outros materiais de interesse de alunos e professores. A proposta não consiste exatamente em um plano para realização de uma oficina, de acordo com o modelo de oficinas do CEEJA, mas sugere a criação de uma ferramenta que poderia atingir uma nova relação de comunicação entre os docentes destas disciplinas, na medida em que o blog seria produzido colaborativamente e entre os alunos e professores. O blog, assim como as redes sociais, vem se tornando uma das mais importantes e práticas ferramentas de comunicação da web 2.0. Ao utilizar esta ferramenta como canal de comunicação e compartilhamento de conhecimento com seus alunos, os professores contribuem com a aproximação entre estudantes e o ciberespaço.

Trata-se, desta forma, de uma proposta potencialmente autoral e indicativa da intenção dos docentes em propor um trabalho com elevado nível de apropriação das TDIC e com grande potencial para se posicionar como uma abordagem de aprofundamento de conhecimento (UNESCO, 2009a; 2009b).

Para Mattar (2013), o crescimento dos blogs, no início dos anos 2000 é uma marca definitiva do avanço da cibercultura. Trata-se de uma ferramenta que permite mais que a criação de uma página pessoal publicada na web: a tecnologia $\operatorname{RSS}^{30}$ permite que o usuário assine uma página, sendo notificado sempre que houver atualização e permite a interação do

\footnotetext{
${ }^{30}$ A tecnologia do RSS permite aos usuários da internet se inscrever em sites que fornecem feeds RSS. Estes são tipicamente sites que mudam ou atualizam o seu conteúdo regularmente. Para isso, são utilizados Feeds RSS que recebem estas atualizações, desta maneira o utilizador pode permanecer informado de diversas atualizações em diversos sites sem precisar visitá-los um a um.
} 
leitor com o desenvolvedor do blog. No campo da educação, o uso de blogs tornou-se uma estratégia didática bastante interessante, na medida em que permite interação colaborativa. Hoje, no entanto, vem perdendo espaço para as redes sociais.

Os professores de Geografia propuseram a criação de uma oficina intitulada "Jogos Geográficos". A descrição da proposta presente no documento é semelhante à oficina que um dos professores já realizava na escola. A proposta consistente em fazer uso de jogos digitais como parte da estratégia didática da disciplina. O plano refere-se especificamente aos conteúdos de coordenadas geográficas e regionalização do Brasil e sugere dois links para as plataformas destes jogos. Os jogos sugeridos não foram analisados nesta pesquisa, mas a opção dos docentes pelo uso de games aproxima-se das concepções trazidas pela formação e vem ao encontro da tendência de gameficação da aprendizagem.

Mattar (2013) também tece interessantes considerações sobre diversos especialistas que tratam do uso de games na educação e ressalta o enorme potencial de interação que podem promover no processo de aprendizagem. Além disso, a proposta também se adequa ao público adulto que, diferentemente do passado, faz cada vez mais uso de games como atividades de lazer, especialmente com a expansão do acesso aos smartfones e seus aplicativos de games gratuitos. Entretanto, ainda que a gameficação seja uma tendência educacional inovadora (MATTAR, 2013), os jogos indicados no plano não indicam uma perspectiva autoral. Trata-se de um plano de oficina que faz uso das TDIC apenas como um apoio ao processo de ensino e, portanto, ainda em uma perspectiva instrumental. De acordo com o ICT-CST (UNESCO, 2009a) trata-se de uma abordagem de Alfabetização Tecnológica, que exige do professor um reduzido nível de apropriação, pois apenas incorpora o uso das tecnologias como ferramenta de ensino.

Também inspirados na gameficação, os professores de Matemática propuseram em seu plano de oficina o uso de um jogo online. A oficina "A Matemática vai ao supermercado" apresenta ao aluno um desafio: realizar compras em um supermercado virtual situado em uma plataforma online dentro de um conjunto de regras, como valor máximo a ser gasto, diferentes opções de preços e produtos e diferentes formas de pagamento e cálculo de juros. Segundo o plano, esta proposta pode simular uma situação real dos estudantes adultos. Por esta característica especial, o documento apresentado pelos professores relaciona-se diretamente com as reflexões de Oliveira (2007) sobre adequação do currículo da EJA à realidade de seus educandos e a situações-problema que condizem com sua idade e saberes prévios. 
Entretanto, "A Matemática vai ao supermercado" é uma oficina que indica um processo menos crítico e autoral de alunos e professores. Além disso, ela é pouco inovadora e se limita à abordagem da Alfabetização em Tecnologia, de acordo com UNESCO (2009a; 2009b), pois exige poucas habilidades dos docentes e não possibilitam processos de criação e de colaboração.

O plano de oficina de Química e Ciências tem por objetivo apresentar a tabela periódica aos alunos, por meio de uma plataforma virtual interativa ${ }^{31}$ que foi conhecida pelos docentes, em pesquisas feitas durante as dinâmicas do curso de formação, conforme descrito em item anterior. O uso deste REA (PRETTO e ASSIS, 2008) poderia proporcionar maior familiarização dos estudantes com menor fluência tecnológica e o hipertexto, além de oferecer à oficina a possibilidade de uma nova dinâmica de interação entre o professor, o educando e os saberes envolvidos. A oficina é condizente com as discussões do curso de formação, sugerindo que a dinâmica de busca por REA de cada área do conhecimento mobilizou os docentes para o planejamento de suas ações futuras.

No entanto, a oficina "Tabela Periódica" também está restrita a uma abordagem distante da perspectiva autoral e crítica que a formação intencionava. Ela representa, evidentemente, uma aproximação dos docentes aos REA e à plataforma interativa da ferramenta, mas centra-se em um nível reduzido de apropriação tecnológica, em uma abordagem restrita à alfabetização tecnológica (UNESCO, 2009a; 2009b)

A oficina planejada pelos professores de Biologia, por sua vez, propõe um trabalho voltado para a habilidade de pesquisar na internet, oferecendo informações sobre ferramentas de buscas na plataforma Google e sobre a seleção qualitativa das informações contidas na rede. Intitulada "As tecnologias como ferramentas de pesquisa da Biologia", a oficina sugere uma exposição sobre as ferramentas de busca e sobre a importância de filtrar dados e informações disponíveis na rede, seguida de uma atividade prática de pesquisa. Nesta atividade, os professores pediriam para que os alunos promovessem suas pesquisas sobre temáticas específicas do currículo de Biologia, de acordo com orientações técnicas para uma boa pesquisa escolar.

Trata-se de uma atividade intencionalmente instrumental, na medida em que dominar as ferramentas de busca na web 2.0 é, sem dúvida, um pré-requisito básico para o processo de inclusão e letramento digital, que na visão de Buzato (2003) e Silva et al (2005) vão muito além do simples uso do computador, mas se relacionam com o domínio dos sujeitos sobre

\footnotetext{
${ }^{31} \mathrm{http}: / / \mathrm{www} \cdot \mathrm{ptable} . \mathrm{com} /$
} 
suas possibilidades e sua vivência da cultura digital. Ainda é restrita à abordagem de Alfabetização em Tecnologia (UNESCO, 2009a; 2009b), apesar de bastante pertinente em relação às reflexões propostas pelo curso de formação.

Por fim, a proposta dos professores da disciplina de Física apresentada em seu plano de oficina consiste em utilizar um simulador virtual do espaço como estratégia didática para uma atividade sobre astronomia. Os professores sugerem que a plataforma Stellarium $^{32}$ seja instalada nos computadores da escola, para que os alunos possam, por meio de sua manipulação, observar o espaço e aprender sobre astronomia. O plano também prevê a exibição de vídeos e a observação real, pelo telescópio.

Para Levy (1999), a simulação é um modo de conhecimento próprio da cibercultura, pois se trata de uma tecnologia que multiplica a imaginação individual e permite que grupos partilhem, negociem e refinem modelos mentais comuns, aumentando a inteligência coletiva. Sem dúvidas, a estratégia de ensinar astronomia por meio de um simulador virtual vai ao encontro das proposições de uso pedagógico das TDIC trazidas pelo curso. Os docentes da disciplina já faziam uso da ferramenta em sala de aula como instrumento de demonstração para seus alunos. No entanto, ao formularem o plano de aulas em conjunto, apostaram na necessidade do estudante manipular o computador, navegando pela plataforma. Essa mudança de postura refletida no documento é representativa da influência do curso em suas práticas.

O uso do simulador pode ser entendido como inovador, mas a dinâmica proposta pelos docentes ainda é bastante centrada no professor e não se posiciona em uma perspectiva de construção de conhecimento. Lévy (1999), ao situar a simulação como um elemento próprio da cibercultura, sinaliza para a potência desse recurso para a cognição humana.

De acordo com ICT-CST (UNESCO, 2009a; 2009b), este plano de oficina posicionase na passagem entre a abordagem de Alfabetização em Tecnologia e a abordagem de Aprofundamento do Conhecimento, na medida em que o uso da ferramenta ainda é um apoio a um processo de ensino muito centrado no professor e nada colaborativo, mas exige do mesmo o domínio de uma plataforma complexa de simulação.

Como visto, os planos de oficinas produzidos pelos professores demonstram resultados parcialmente positivos em relação à influência do curso de formação sobre sua percepção do uso educacional das TDIC. É possível observar relação entre todos eles e os pressupostos do curso, porém ainda se identifica perspectivas instrumentais e distantes do ideal de autoria e colaboração. O quadro abaixo sintetiza a análise, de acordo com dois

\footnotetext{
${ }^{32} \mathrm{http} / / / \mathrm{www}$. stellarium.org/pt/
} 
parâmetros: a) a distância da proposta em relação à perspectiva crítica, isto é, pautadas pela intencionalidade autoral e criativa de alunos e professores; b) o documento "Padrões de competências em TIC para professores" (ICT-CST), elaborado pela Unesco (2009a; 2009b).

Quadro 7 - Síntese da análise dos planos de oficina

\begin{tabular}{|c|c|c|}
\hline Oficina & Perspectiva & Abordagem (ICT-CST) \\
\hline FanFiction & Autoral e Colaborativa & $\begin{array}{l}\text { Aprofundamento do } \\
\text { Conhecimento }\end{array}$ \\
\hline Blog de Ciências Humanas & $\begin{array}{l}\text { Potencialmente autoral e } \\
\text { colaborativa }\end{array}$ & $\begin{array}{l}\text { Aprofundamento do } \\
\text { Conhecimento }\end{array}$ \\
\hline Jogos Geográficos & Instrumental & Alfabetização em Tecnologia \\
\hline $\begin{array}{l}\text { A Matemática } \\
\text { Supermercado }\end{array}$ & Instrumental & Alfabetização em Tecnologia \\
\hline Tabela Periódica & Instrumental & Alfabetização em Tecnologia \\
\hline $\begin{array}{l}\text { As tecnologias como } \\
\text { ferramentas de pesquisa da } \\
\text { Biologia }\end{array}$ & $\begin{array}{l}\text { Instrumental, porém } \\
\text { fundamental no processo de } \\
\text { inclusão digital }\end{array}$ & Alfabetização em Tecnologia \\
\hline Astronomia & Instrumental & Alfabetização em Tecnologia \\
\hline
\end{tabular}

Fonte: elaborado pelo pesquisador

Os professores tiveram liberdade de realizar planos individuais, em parceria com seus colegas de disciplinas ou área de conhecimento. Evidentemente, pela análise dos planos, não é possível generalizar a percepção de todos os docentes sobre o curso. Além do mais, não é possível determinar, por meio da análise documental, se estas oficinas foram todas executadas, se sua execução esteve de acordo com o planejado e se efetivamente todos os professores que assinaram os planos participaram de sua elaboração e execução. Isto significa que os planos, enquanto documentos, são insuficientes para responder ao nosso problema de pesquisa, por isso o próximo item analítico concentra-se na análise temática de conteúdo das entrevistas junto os sujeitos de pesquisa.

\subsubsection{Análise Temática de Conteúdo}

A análise dos dados coletados por meio das entrevistas com os sete sujeitos de pesquisa, seis docentes e o professor coordenador, foi dividida em duas categorias, com o objetivo de sistematizar as principais pistas que possam atender aos objetivos desta pesquisa. São elas: A) Nível de apropriação tecnológica dos docentes e empoderamento; B) Pertinência e aproveitamento do curso.

É oportuno observar que a transcrição, na íntegra, dos depoimentos reproduz fielmente a coloquialidade característica da linguagem oral. As transcrições, na íntegra, seguem como anexos C a I. 


\section{CATEGORIA A - Nível de apropriação tecnológica dos docentes e empoderamento}

A categoria de análise "Nível de apropriação tecnológica dos docentes e empoderamento" toma por base analítica os autores presentes nas discussões dos capítulos teóricos deste trabalho, além dos já apresentados Padrões de Competência em TIC para professores (ICT-CST) (UNESCO, 2009a; 2009b).

Para ajudar a compreender o nível de apropriação tecnológica dos docentes e do coordenador entrevistados, são utilizadas as repostas às perguntas de 1 a 5 do roteiro de entrevista (APÊNDICE B).

Todos os entrevistados confirmaram que a tecnologia está de alguma forma presente em suas vidas, ainda que demonstrem níveis diferentes de apropriação. Os sujeitos afirmaram fazer basicamente o uso de smartphones, redes sociais, computador, ferramentas de pesquisa, vídeos e datashow. A precisão da resposta de cada um à pergunta "Você faz uso das tecnologias digitais? Quais?" ajuda na compreensão da clareza do docente sobre o que são as TDIC.

As docentes Rita de Cássia, Cláudia, Silvana e Maria, por exemplo, demonstraram facilidade em elencar seus usos pessoais, o que pode ser um indício de uma relação mais próxima entre os sujeitos e as TDIC:

Ah, praticamente eu uso o smartphone, também como fonte de pesquisa, na elaboração de trabalhos pessoais. Tenho pesquisado muito a questão de comportamento, por conta do meu filho. E para lazer também. (Prof. ${ }^{a}$ Rita de Cássia)

[Uso, grifo nosso] As redes sociais, para trabalho e pesquisa. E também para comunicação. (Prof. ${ }^{a}$ Cláudia)

[Faço uso, grifo nosso] Pessoal sempre, pra pesquisa, pras redes sociais, sempre. Para a escola eu uso, além do datashow, dos multimeios, eu utilizo, não, eu utilizei uma vez, que foi para fazer o fanfiction. (Prof. ${ }^{\text {a Silvana) }}$

Eu uso muito o computador para fazer compras, pagar contas, trabalhar, redes sociais. Falo muito com minha família e meus amigos pelas redes sociais. (Prof. ${ }^{a}$ Maria)

Os docentes, Luiz Roberto, Vinícius e o coordenador Renato, por outro lado, tiveram dificuldade em elencar seus usos pessoais e demandaram a intervenção do pesquisador para construção de uma reposta:

Tecnologias que você fala é computador, datashow? (Prof. Renato)

Não, basicamente, você falou do que? Em relação à internet? (Prof. Vinícius) 
Faço [uso de tecnologias, grifo nosso]. Exemplos? Faço em termos de redes sociais e tudo mais, eu faço. Agora, voltando, em escola regular [...] (Prof. Luiz Roberto)

Ao serem questionados sobre os usos das TDIC em suas práticas no CEEJA, os sujeitos trouxeram usos diferentes, principalmente ligados às suas práticas mais comuns, que vão desde o uso do computador na elaboração de provas, até o uso das TDIC em oficinas, o que indica, já de antemão, que há diferenças entre eles, no que se refere ao domínio de habilidades tecnológicas.

Ao responder à segunda questão do roteiro, "Você faz uso de tecnologias digitais nas suas práticas pedagógicas aqui no CEEJA? Dê exemplos”, a Prof. ${ }^{a}$ Rita de Cássia demonstra preocupação em incentivar seus alunos quanto ao uso da sala de informática e o uso de vídeos pedagógicos como estratégia didática.

A gente [professores de Química, grifo nosso] utiliza o computador como meio de vídeo, disponibilizado pelo próprio programa "EJA no mundo do trabalho", como um item de estudo, ele é obrigatório em uma prova e ele é facultativo nas outras, mas a gente incentiva bem o uso disso. Alguns trabalhos que são complementares do material que a gente está utilizando, a gente também utiliza como pesquisa da internet. E especificamente da internet que é para que ele tenha esse contato com essa sala [de informática], que acho que era o ponto principal, a utilização da sala de informática e da sala de leitura. $\mathrm{E}$ eu acho que essa prática de ter vários trabalhos fez com que eles utilizassem mais aqui até para outras coisas. (Prof. ${ }^{a}$ Rita de Cássia)

A Prof. ${ }^{\text {a }}$ Cláudia cita o uso de mais recursos: vídeos, documentários, ferramentas de pesquisa, Facebook e as plataformas de jogos online com conteúdos de Geografia, já descritas em seu plano de oficina. Algumas destas ferramentas sugerem maior interação com os alunos, o que indica uma preocupação maior com a interatividade e com o desenvolvimento de habilidades tecnológicas no estudante adulto.

A Prof. ${ }^{a}$ Maria, que leciona física e desenvolveu uma oficina com uso de um simulador astronômico, também exaltou em sua resposta o uso de vídeos e de ferramentas de comunicação para contatar os alunos com frequência irregular.

Eu trago sempre meu computador para cá. É mais prático. Entre um aluno e outro estou no computador trabalhando [...]. [Faço uso das TDIC, grifo nosso] Principalmente pesquisando, elaborando prova, montando PowerPoint, pesquisando vídeos para as oficinas. Uso para isso mesmo. Também uso, às vezes, para me comunicar com algum aluno. Quando um aluno some, mando uma mensagenzinha pelo Facebook. Eles ficam felizes e acabam voltando, [...] Também [uso, grifo nosso], através dos vídeos. Os vídeos que nós pesquisamos, utilizamos para complementar o que foi, o que vai ser falado na oficina. Eles deixam mais dinâmico. (Prof. ${ }^{a}$ Maria) 


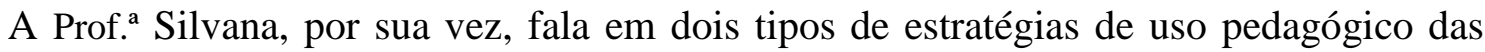
TDIC. A primeira com uso de ferramentas menos interativas, em oficinas de inglês com uso de vídeo e áudio, que, segundo ela, não possuem tanta interação, já que os alunos não manipulam as tecnologias. A segunda, como uma estratégia da oficina "FanFiction", cujo plano foi analisado em item anterior. A professora explica de que forma se deu a experiência:

A ideia era eles produzirem um texto já dentro de uma página voltada para qualquer tipo de gênero. Então a gente, eu criei um gênero, dentro de uma data comemorativa, que a gente fez um trabalho com um filme da Frida [Kahlo, grifo nosso]. Eu comecei a história utilizando um fato que aconteceu e os alunos faziam vários parágrafos, lendo o que foi escrito, para treinar a leitura, e escrevendo, treinando a escrita também. Já escreviam direto na página do fanfiction. Eu cadastrei o nome da escola para eles poderem depois ter acesso ao texto completo. [...] Eu pensei não no inglês, eu pensei na nossa língua mesmo, porque a gente não tem a prática de escrever. Aí eu decidi unir a falta de prática de leitura e de escrita do aluno, mas com uma linguagem nova, que é uma página, um website com tantos outros gêneros. Eu escolhi, fiz um mote, aquele início, mas eu poderia ter deixado eles fazerem, cada um tipo de texto que quisesse. Porque o fanfiction, a gente usou uma realidade nossa, mas a ideia é que você possa usar um personagem dentro de uma história que você goste, dentro de um filme, música ou qualquer área que você se encante. Você pode fazer uma história sobre aquilo, sendo um personagem. A ideia é essa. Foi isso que eu pensei: ele é um personagem do próprio lugar em que ele estuda, para ele saber até que ele faz parte. Tanto que eles fizeram, um falava sobre e com o outro, não se conhecendo, mas falando como se tivessem dialogando, porque é o que acontece nos corredores do CEEJA. Então eles recriaram alguma vivência deles. É essa a ideia. (Prof. ${ }^{a}$ Silvana)

Os usos feitos pelas docentes Rita de Cássia, Cláudia, Maria e Silvana indicam uma preocupação grande com o que Bonilla (2010) define como "vivência plena da cultura digital". Isto porque os usos das TDIC, em suas visões não se restringem apenas a experiências passivas e indicam que há preocupação com a interação entre o aluno e as TDIC. A descrição da oficina "FanFiction", em especial, representa, entre as falas dos sujeitos, a experiência mais próxima de uma perspectiva autoral (PRETTO, 2012).

Por outro lado, o Prof. Luiz Roberto afirma não fazer uso de tecnologias em suas práticas no CEEJA, apesar de reconhecer sua importância:

Não [faço uso das TDIC aqui, grifo nosso]. Olha, poderia fazer mais, né? Poderia fazer mais, mas ainda não acho que faço em bom número. Pelo menos aqui nesse espaço. Talvez na escola regular eu consiga utilizar mais. Não tem muita estrutura e tudo mais, mas aqui, como espaço educativo ainda não vingou. (Prof. Luiz Roberto)

A fala do Prof. Vinícius releva que o uso das tecnologias ocorre muitas vezes como meio para preparação de aulas e material, mas não como vivência e incorporação de seu uso nas práticas escolares, por exemplo. 
Na verdade, para mim, diretamente para mim, eu faço bastante [uso das TDIC, grifo nosso], no sentido de pesquisas, né? Pesquisas, preparação de oficinas, de palestras, essas coisas. Indiretamente, no sentido de sempre estimular o aluno a pesquisar, a aprofundar o assunto, direcionando, utilização dos instrumentos da escola, do aparelhamento da escola, nesse sentido. (Prof. Vinícius)

É possível notar na fala dos professores Luiz Roberto e Vinícius certo receio em assumir para si o desafio de promover práticas pedagógicas com o uso das TDIC. Não seria correto afirmar, desta forma, que estes docentes possuem elevado nível de apropriação tecnológica, de acordo com ICT-CST (UNESCO, 2009a; 2009b), pois não parecem dominar habilidades básicas descritas pela abordagem de Alfabetização Tecnológica, como “incorporar as atividades apropriadas em TIC aos planos de aula, de modo a ajudar o processo de aquisição, pelos alunos, do conhecimento da disciplina escolar" (UNESCO, 2009b, p.9) ou a capacidade de "integrar o uso de um laboratório de informática às atividades de ensino em andamento" (UNESCO, 2009b, p.10).

Entretanto, entre as falas dos docentes que afirmaram fazer uso pedagógico das TDIC, com exceção da fala da Prof. ${ }^{a}$ Silvana, pouco está presente a perspectiva autoral advogada por Belloni (1998), Pesce (2013a) e Pretto (2012). Esta percepção é um indício da insuficiência do curso "Mídias Digitais na Educação de Jovens e Adultos" como um instrumento de empoderamento docente para o uso crítico das TDIC (PESCE, 2013a).

As dificuldades, segundo estes dois sujeitos, estão ligadas à motivação docente e às características do atendimento individualizado dos alunos do CEEJA. Ao responder à terceira pergunta do roteiro, o Prof. Luiz Roberto fala sobre a falta de iniciativa como uma dificuldade para uso pedagógico das TDIC, enquanto o Prof. Vinícius fala sobre os problemas do número de alunos atendidos e da dificuldade em acompanhar individualmente seus alunos na sala de informática, enquanto há outros alunos a serem atendidos.

Eu acho assim, não existe dificuldade, bom, de técnica, talvez um pouco, não muito. Tem sim, técnica, muito mais do que uma restrição administrativa, entendeu? Administrativamente, eu acho que o espaço permite muito mais do que a gente faz. [...] [Temos, grifo nosso] Estrutura e tudo mais. A nossa estrutura é mínima. Mas o que falta mesmo que eu vejo é uma busca da utilização disso. A iniciativa [é uma dificuldade, grifo nosso] sim. Porque você conhece algum - como que eu posso chamar? - meios, não, - qual o nome, por favor? - você conhece alguma tecnologia, as mídias, você conhece ou meio que conhece, não há uma restrição administrativa para tanto, tecnologicamente você tem alguns limites, mas o que falta mesmo é iniciativa. No meu caso é falta de iniciativa mesmo. Quer dizer, eu não consegui pensar ainda, apesar de todo esse processo e de várias discussões que a gente teve em torno disso, ainda falta aquela coisa de você inserir no seu cotidiano, né? Então, eu ainda não consegui inserir em meu cotidiano da forma que eu acho que poderia ser. [...] Acho que iniciativa é o principal [dificultador, grifo nosso] por dois motivos. Um por uma questão mesmo de iniciativa e outro pela questão do 
desconhecimento. No meu caso, eu não vou dizer que seja desconhecimento. Eu preciso mesmo parar e pensar em como estruturar isso. (Prof. Luiz Roberto)

Acho até que não [há dificuldades, grifo nosso]. É um sistema diferenciado de ensino, a gente tem 0 atendimento na sala. Mas eu acho que o que está proporcionando, na medida do possível, uma sala de informática, eu acho que há possibilidade dessa prática. $E$ há professores que até trabalham diretamente, como você falou, nessa linha de usar diretamente, por exemplo, dinâmicas ali, virtuais. Muitos que já utilizam, né? É uma questão até de, na minha área mesmo [de Língua Portuguesa, grifo nosso] tem professores que utilizam em algumas oficinas, fazem ações que utilizam do computador, de um sistema online. [...] Acho que a grande dificuldade, no sistema daqui, no sistema regular, sobretudo no ensino público, é a quantidade de alunos e o material, os aparelhos disponíveis. Aqui é um pouco essa questão da circulação do aluno. Você pode até fazer um trabalho mais individualizado, mas aí existe um outro problema que você teria que, se fosse um atendimento individual, aliás, é um atendimento individual, mas do ponto de vista tecnológico, teria que acompanhar o aluno, para estar do lado dele, e nem sempre você tem uma pessoa para fazer um outro tipo, uma contrapartida, um outro tipo de atendimento mais rústico, digamos assim. (Prof. Vinícius)

Ao encontro desta fala, a Prof. Cláudia também atribui à individualização e à flexibilidade da frequência do aluno do CEEJA um possível entrave para o trabalho com tecnologias, que não existiria em escolas com aulas e classes regulares.

É, falta de continuidade. Porque você começa lá com o jogo sobre coordenadas geográficas, você está estudando latitude, a parte da longitude, vai trabalhar com meridianos relacionar com paralelos, né? Nessa parte, assim, o que eu quero aprofundar mais até chegar no GPS, para eu explicar essa parte, dá aquela quebra. Porque eu não vou ter o mesmo aluno para continuar. Acho que eu vejo assim. (Prof. ${ }^{\text {a Cláudia) }}$

Para a Prof. ${ }^{a}$ Maria, motivação e problemas com a conexão à internet também são as principais dificuldades. A docente trata de uma questão também discutida na pesquisa de Santos (2011) e de Lavinas e Viegas (2013), a falta de políticas públicas de investimento em infraestrutura que garantam conexão de qualidade para as escolas públicas. Além disso, a docente foi a única a citar espontaneamente a falta de formação como uma dificuldade para a incorporação do uso das TDIC nas práticas dos professores do CEEJA, o que remonta às perspectivas de autores como Belloni (1998), Barreto (2002) e Almeida e Silva (2011).

A internet cai muito, né? Atrapalha quando a gente precisa usar e fica caindo. Mas fora isso. A escola ajuda também, porque aqui no CEEJA a gente tem um pouco mais de tempo para isso. Aqui dá para gente planejar, planejar coletivamente, até com outros professores, de outras disciplinas. Mas acho que a gente faz pouco. Podia ter mais, já que é mais fácil fazer aqui. [...] A dificuldade é a falta de motivação mesmo, vontade. Eu mesma tento, vou tentando fazer. Não faço muito, mas faço o que eu sei só. Mas tem gente que sabe muito, mas faz pouco. E tem gente que não sabe também. [...] Falta formação. Falta, mas quando tem o pessoal não valoriza. Sabe como é, né? O coordenador tenta, planeja, cria, mas o professor vê como castigo. Eu tento me dedicar. (Prof. ${ }^{a}$ Maria) 
É possível notar a inexistência de consenso sobre a facilidade ou dificuldade de adaptar atividades com uso de TDIC no sistema organizacional do CEEJA, na medida em que, de um lado, os docentes Vinícius, Cláudia e Silvana apontam dificuldades e, de outro, a docente Maria fala em facilidade e mais tempo para fazer uso de tecnologias.

A docente Cláudia aponta para outra dificuldade para uso das tecnologias no CEEJA: a insegurança do docente diante das TDIC. É possível relacionar sua fala com as da Prof. ${ }^{\text {a }}$ Maria e do Prof. Luiz Roberto, para quem, respectivamente, a falta de formação e de iniciativa atravanca as mudanças nas práticas docentes.

Por parte da direção, acho que [há apoio, grifo nosso] sim. Mais problema é da gente mesmo, né? É o receio de mexer com a tecnologia. É tecnofobia que fala? Tem professor que, dependendo do professor, tem medo de mexer por ele não conhecer as técnicas, como mexer, como estar usando e manuseando aquilo. Acho que ainda tem aquele medo de por a mão. Eu meto as caras. [risos, grifo nosso] Eu vou assim, né? Eu vou observando, vou indo e, dependendo do aluno, até ele sabe mais que a gente, né? Então aprendo também com eles. (Prof. ${ }^{a}$ Cláudia)

Para Silvana, há três entraves para o uso pedagógico das TDIC no CEEJA: a escassez de tempo, diante do currículo e da flutuação da frequência do estudante da escola, a dificuldade de parte dos alunos em manusear as ferramentas tecnológicas e, o principal, segundo ela, a existência de poucos computadores na escola.

A dificuldade é só que tem que ter um computador meu, né? Para usar na minha sala, sem ter que ir com o aluno para a sala de informática, porque nem sempre dá para sair. Isso limita um pouco. Mas claro, se eu fosse usar sempre a sala de informática, eu também limitaria os outros, que usam para pesquisa. [...] $\mathrm{E}$ alguns [alunos], tanto do fundamental quanto do médio, não tinham, não sabiam lidar mesmo, eram analfabetos, não sabiam lidar com o computador, com o teclado, não sabiam o básico. E aí eu tive que ensinar. [...] Como a gente trabalha com pessoas de mais idade, então os que tinham mais idade tiveram muito mais dificuldade. Algumas senhoras, né? Teve um senhor que não sabia nada. [...] Demorou muito mais. É uma grande dificuldade. Porque você já não tem o tempo, você só tem aquele espaço e aquele computador, então aquele aluno me tomou a tarde inteira para fazer um parágrafo. Isso sem você poder dar tanta atenção, porque você está fazendo isso junto com as provas. [...] Mas é uma dificuldade para um projeto. Se fosse uma coisa diária, já não poderia acontecer, não funcionaria. Enquanto um projeto, uma oficina, como foi a proposta, beleza. Mas se fosse uma coisa para ser feita sempre. [...] Agora, só é viável se for um projeto, diário não. Nesse caso nosso, nessa nossa realidade. (Prof. Silvana)

A posição da Prof. Rita de Cássia, entretanto, é de que as dificuldades não existem no CEEJA, como há em outras escolas.

Aqui não [há dificuldades, grifo nosso]. Mas, assim, eu comecei a dar aula em 1993. Quando surgiram as primeiras salas de informática a gente não tinha acesso à internet. A gente tinha programas que vinham, que eram disponibilizados pelo Estado, e eu sempre utilizei o "fracionando", o "como as coisas funcionam". Não sei 
se você teve acesso a isso, porque você não era nem nascido. [...] Eu era uma das únicas professoras que levava eles para utilizar esses softwares. Tem uma série de outros softwares. E aí, na escola aqui [...] também utilizei um software de química, que é um laboratório virtual, mas a gente sempre encontrou muitos entraves. Quando eu comecei aqui eu tinha uma diretora que ela achava que o material, o equipamento quebrava porque ele estava sendo usado. Então, isso nos deu muita liberdade para trabalhar. Mas encontrei diretores também que pensavam ao contrário, que a sala não podia ser utilizada, se não ia quebrar. Porque a gente sabe que a manutenção é difícil, manter os computadores funcionando é complicado. $E$ eu não vejo muito isso aqui no CEEJA. Então, a dificuldade que eu sinto, que nós sentimos, por exemplo, foi até uma reivindicação, porque no primeiro mês aqui no CEEJA teve uma explosão de oficinas. Então, como não tinha espaço, usavam muito essa sala. A gente começou a interferir nisso, porque ela é um instrumento de estudo para a avaliação. Então a gente pediu para que essa sala não fosse utilizada tanto. Esse foi um dos entraves no começo do ano. $\mathrm{O}$ aluno ficava brecado [de usar a sala, grifo nosso]. (Prof. ${ }^{a}$ Rita de Cássia)

O relato da docente, especialmente ao tratar da dificuldade em fazer uso do laboratório de informática em algumas escolas, vai ao encontro das perspectivas de Silveira (2008) e Lavinas e Veiga (2013), para quem a escola deve ser um ambiente propício para a promoção da cultura digital e da aprendizagem. Além do mais, sem acesso livre a espaços como este, não é possível promover a vivência plena na cultura digital, como quer Bonilla (2010).

É possível compreender, na medida em que nenhum docente considera a gestão do CEEJA como uma dificuldade em fazer uso das TDIC, que a direção da escola em tela procura oferecer apoio e condições, dentro das limitações estruturais, para o desenvolvimento de atividades deste tipo. É evidente, em suas falas, que o restrito número de computadores e a dinâmica de atendimento individualizado atravancam as práticas dos professores dispostos a incorporar tecnologias em seu cotidiano escolar.

A questão número 4 do roteiro de entrevista preocupou-se em comparar as práticas com uso de TDIC dos docentes que, além do CEEJA, atuam em outras escolas. As docentes Rita de Cássia, Cláudia e Maria atuam também em escolas privadas do município, enquanto os docentes Luiz Roberto e Vinícius atuam, respectivamente, em uma escola da rede pública estadual e municipal.

Ao responder a questão "Você é professor de escola regular? Se sim, você integra as TDIC às suas práticas escolares? Você planeja as mesmas atividades na escola regular e no EJA?” a docente Rita de Cássia esclareceu que a escola privada em que atua não incentiva estas práticas e não possui laboratório de informática e que, portanto, seus usos pedagógicos das tecnologias são restritos ao CEEJA. Já os docentes Cláudia, Maria e Vinícius, por sua vez, explicam as diferenças a dificuldades em adaptar as mesmas práticas em escolas diferentes, principalmente por conta da heterogeneidade de faixas etárias entre os alunos da EJA e das 
escolas regulares em que atuam, além, é claro, da própria diferença entre a estrutura organizacional das escolas.

É diferente [na outra escola, grifo nosso]. Assim, quando é adolescente, eles caminham por si só. Em algumas coisas assim eles até avançam mais que a gente e até - como eu te falei - até auxiliam a gente. Essa é que é a grande diferença. [...] Depende também do aluno, da idade, do tempo, né? [...] Porque aqui, como é a presença flexível, você nem sempre tem aquele mesmo aluno para dar continuidade, o que acho que é a dificuldade de desenvolver esse trabalho aqui. Vamos supor: eu começo hoje, marco uma pesquisa, se eu quero continuar com ela em um outro dia, eu já não vou ter o mesmo aluno. Eu vou ter alunos e grupos diferentes. Essa diferenciação que eu acho que dá uma quebra no trabalho. (Prof. ${ }^{a}$ Cláudia)

São realidades diferentes [o CEEJA e a escola privada regular, grifo nosso]. Acho que até daria [para executar as mesmas atividades]. Por exemplo, os vídeos, o simulador, acho que não. Os vídeos eu uso, usava. Eu usei alguns lá e aqui o ano passado. A gente explica de forma diferente, porque aqui os alunos são muito diferentes, né? Muitas idades diferentes, às vezes pouca base. Os vídeos servem para ilustrar, aproximar o aluno da matéria. Lá eu usava também, mas como uma aula expositiva. Aqui o vídeo é ou para a oficina, ou para o aluno explicar, quer dizer, entender melhor o que está vendo. (Prof. ${ }^{a}$ Maria)

Não [executo as mesmas atividades no CEEJA e na escola regular, grifo nosso], pela diferença de sistemas. É que aqui também é diferente, lá eu trabalho com uma faixa etária de catorze anos, né? É ensino fundamental regular, você tem que ter um outro tratamento. Não nesse sentido, acho que o foco aqui, que eu trago mais efetivamente nas oficinas e nas palestras, basicamente nas oficinas ou no círculo de leitura. E aí é diferente o nível de alcance, o tipo de objetivo é diferente. (Prof. Vinícius)

Apesar de não fazer uso das TDIC em sua atuação pedagógica no CEEJA, o Prof. Luiz Roberto percebe a necessidade e a possibilidade de trazer estratégias já desenvolvidas por ele com alunos de escola regular.

É, eu acho que hoje eu posso [planejar as mesmas práticas para o CEEJA e a escola regular, grifo nosso]. Assim, o tempo que eu tenho de CEEJA é curto. Então eu estou assim, tateando. Mas acho que hoje eu consigo colocar algumas coisas. Eu até estava pensando. Eu fiz um trabalho com os alunos, de um blog que eu tenho, e que eu posso estar utilizando gradativamente dentro do CEEJA. [...] Hoje o que a gente tem? 0 aluno tem uma avaliação com oito pontos, uma prova escrita, e uma tarefa que ele escreve e a gente anexa. Isso poderia ir para a sala, nosso laboratório, e o cara digitar e mandar, ele ter essa opção de fazer. Ou a sala de informática aqui da escola ou utilizar a casa, o ambiente que ele quiser. (Prof. Luiz Roberto)

Sobre a questão de transposição de atividades do ensino regular para a EJA, autores como Ribeiro (1999) e Oliveira (2007) apontam para o perigo de uma adaptação inconsistente, que não se adeque à faixa etária e à pluralidade de perfis presente na 
modalidade. Di Pierro (2010b) alerta para a urgência da formação específica de docentes da EJA, como estratégia para que esta transposição não seja automática e acrítica.

O professor coordenador Renato também foi questionado sobre sua visão diante do uso pedagógico das TDIC entre os docentes da escola. Em sua visão, as ações com uso de tecnologias são estimuladas pela equipe gestora e, desta forma, contribuem para mudanças nas práticas docentes.

Eu utilizo durante os trabalhos de reuniões com os professores, com todos os segmentos. E procuro direcionar também esse trabalho para as atividades com alunos, no acompanhamento das atividades com alunos e professores. Alguns recursos, áudio, vídeos. Por exemplo, nos últimos tempos demos continuidade aquela questão da montagem dos vídeos dos professores. Seria isso também? Eles tiveram a formação. [...] Na verdade, a gente plantou uma sementinha. $O$ resultado que virá com o tempo, ainda é algo que a gente não tem uma - como eu posso dizer? - não tem uma previsão do que vai acontecer num todo. (Prof. Renato)

O coordenador, no entanto, percebe a resistência de parte dos professores, como insegurança em sua relação com as novas tecnologias e, desta forma, valoriza a necessidade de formação continuada para promoção do uso pedagógico das TDIC.

Ela [a resistência, grifo nosso] talvez exista, mas quando você mostra para o professor que não existe tanta complicação assim, acredito que a resistência maior é naquele sentido que eu disse, a vergonha de aparecer, de se expor, ou a questão de não querer sair de uma zona de conforto. Talvez esteja aí a resistência, mas quando eles percebem que não é tão complicado assim, por exemplo, de usar, eles visualizam e veem que a coisa não é tão difícil. $E$ também, Bruno, tudo se dá através de um processo. Não dá para eu, coordenador, chegar na escola e falar: olha, no próximo ATPC a gente vai montar vídeo-aulas. Então existe todo um processo, tem que mostrar a importância, o objetivo do uso do vídeo ou de qualquer outra tecnologia e recurso. Tem que fazer um trabalho de formação continuada com os professores para conhecerem os recursos que a máquina oferece, para que ele tenha conhecimento, para que ele tenha essa facilidade de poder executar 0 trabalho. Não é um trabalho que dá para ser feito de um dia para o outro. Precisa ter o que? Uma formação continuada nesse sentido. Por mais que a gente saiba que tem professores que dominam muito bem, por outro lado tem aquele que não tem muito domínio. Então a troca de informação entre a pessoa que está fazendo a formação e até mesmo o professor que está ali, que às vezes supera a expectativa de quem está fazendo a formação continuada, vai estar interagindo e o professor vai estar se familiarizando com a situação, com a novidade, e vai ficando mais fácil de executar. (Prof. Renato)

De acordo com o que ensina Freitas (2010), é preciso formar os professores, que não são nativos digitais para possibilitar, além de constante atualização, a construção de um olhar crítico diante das tecnologias. Em confluência, Barreto (2002), Pesce (2013a), Almeida e Silva (2011) falam da necessidade de se propiciar formação para uso das TDIC a partir de uma perspectiva mais autoral. 
Além disso, a fala do coordenador também sinaliza para uma preocupação com o fortalecimento das ATPC como um espaço de formação. A perspectiva de valorização da formação continuada em serviço vai ao encontro das análises de Imbermón (2000), Aquino e Mussi (2001) e Placco (2010), que indicam para as circunstâncias que a formação continuada precisa estar inserida. Especialmente o pesquisador português Canário (1999), fala da importância de que esta formação continuada seja centrada na escola, como modo de valorizar os conhecimentos dos docentes mais experientes e como forma de conectar as estratégias de formação à própria realidade da unidade escolar, um processo de troca também valorizado por Tardif (2014) e Nóvoa (1995;1999).

Ao procurar definir os níveis de apropriação tecnológica dos docentes entrevistados, é possível anotar três grupos distintos, dois ainda restritos ao padrão de competência de Alfabetização em Tecnologia e um que avança para a abordagem do Aprofundamento do Conhecimento, de acordo com a ICT-CST (UNESCO, 2009a; 2009b), mas em diferentes estágios de apropriação das suas habilidades básicas.

Para sistematizar a análise, o quadro abaixo classifica os docentes em três níveis de apropriação:

a) Alfabetização em Tecnologia incipiente: refere-se ao docente que possui reduzido uso das TDIC em suas práticas, ainda que as tecnologias sejam úteis para seu uso pessoal;

b) Alfabetização em Tecnologia definitiva: refere-se ao docente que já faz uso das TDIC em suas práticas pedagógicas de forma constante, mas ainda é bastante restrito à perspectiva instrumental, sem que haja um processo de autoria e inovação;

c) Aprofundamento do Conhecimento incipiente: refere-se ao docente que concluiu o processo de alfabetização tecnológica e desenvolve habilidades mais complexas, iniciando um movimento de ruptura com a perspectiva instrumental e acrítica.

Quadro 8 - Síntese do nível de apropriação tecnológica dos sujeitos de pesquisa

\begin{tabular}{|c|c|c|c|c|}
\hline Docente & $\begin{array}{l}\text { Execução } \\
\text { do Plano de } \\
\text { Oficina } \\
\end{array}$ & $\begin{array}{c}\text { Exemplos de uso } \\
\text { pedagógico das } \\
\text { TDIC } \\
\end{array}$ & $\begin{array}{l}\text { Dificuldades para o uso } \\
\text { das TDIC apontadas }\end{array}$ & $\begin{array}{c}\text { Nível de } \\
\text { apropriação } \\
\text { tecnológica } \\
\end{array}$ \\
\hline $\begin{array}{l}\text { Prof. }{ }^{\text {a }} \text { Rita de } \\
\text { Cássia }\end{array}$ & Sim & $\begin{array}{lr}\text { Pesquisas, vídeos, } \\
\text { redes sociais, blog e } \\
\text { plataforma } \\
\text { consulta à tabela } \\
\text { periódica. }\end{array}$ & Não observa dificuldades & $\begin{array}{l}\text { Alfabetização } \\
\text { em tecnologia } \\
\text { definitiva }\end{array}$ \\
\hline Prof. ${ }^{\text {a }}$ Cláudia & Sim & $\begin{array}{l}\text { Pesquisas, vídeos, } \\
\text { redes sociais e } \\
\text { games } \quad \text { (jogos } \\
\text { geográficos) }\end{array}$ & $\begin{array}{l}\text { 1.Insegurança dos } \\
\text { professores com o uso de } \\
\text { novas tecnologias }\end{array}$ & $\begin{array}{l}\text { Alfabetização } \\
\text { em tecnologia } \\
\text { definitiva }\end{array}$ \\
\hline Prof. ${ }^{\text {a }}$ Silvana & Sim & Pesquisas, vídeos, & 1.Modelo & Aprofundament \\
\hline
\end{tabular}




\begin{tabular}{|c|c|c|c|c|}
\hline & & $\begin{array}{l}\text { áudio, redes sociais, } \\
\text { plataforma } \\
\text { colaborativa } \\
\text { FanFiction }\end{array}$ & $\begin{array}{l}\text { escassez de tempo para o } \\
\text { uso das TDIC. } \\
\text { 2.Inabilidade de parte dos } \\
\text { alunos diante do } \\
\text { computador. } \\
\text { 3.Poucos computadores } \\
\text { disponíveis. }\end{array}$ & $\begin{array}{c}\text { o do } \\
\text { conhecimento } \\
\text { incipiente }\end{array}$ \\
\hline Prof. ${ }^{a}$ Maria & Sim & $\begin{array}{l}\text { Pesquisas, vídeos e } \\
\text { simulador } \\
\text { astronômico }\end{array}$ & $\begin{array}{l}\text { 1.Desmotivação de parte } \\
\text { dos professores. } \\
\text { 2.Problemas de conexão } \\
\text { da internet. } \\
\text { 3.Falta de formação } \\
\text { docente. }\end{array}$ & $\begin{array}{c}\text { Alfabetização } \\
\text { em tecnologia } \\
\text { definitiva }\end{array}$ \\
\hline $\begin{array}{l}\text { Prof. Luiz } \\
\text { Roberto }\end{array}$ & Não & $\begin{array}{l}\text { Blog (utilizado em } \\
\text { outra escola) }\end{array}$ & $\begin{array}{l}\text { 1.Falta de iniciativa dos } \\
\text { professores. }\end{array}$ & $\begin{array}{c}\text { Alfabetização } \\
\text { em tecnologia } \\
\text { incipiente }\end{array}$ \\
\hline Prof. Vinícius & Não & Sem exemplos & $\begin{array}{l}\text { 1.Poucos computadores; } \\
\text { 2.Modelo } \\
\text { impossibilita acompanhar } \\
\text { os alunos na sala de } \\
\text { informática }\end{array}$ & $\begin{array}{c}\text { Alfabetização } \\
\text { em tecnologia } \\
\text { incipiente }\end{array}$ \\
\hline
\end{tabular}

Fonte: Elaborado pelo pesquisador.

O professor coordenador Renato não foi incluído na tabela, pois suas respostas se referiram ao contexto geral das práticas docentes do CEEJA e não especificamente às suas habilidades de uso das TDIC.

Conforme o quadro anterior, apenas a Prof. ${ }^{a}$ Silvana pode ser classificada dentro do padrão Aprofundamento do Conhecimento, ainda que de forma incipiente, por demonstrar em sua fala algumas habilidades deste nível de apropriação tecnológica (UNESCO, 2009a; 2009b). Os demais professores, com certa variação, já demonstram habilidades para a abordagem Alfabetização em Tecnologia, mas ainda estão bastante restritos ao uso instrumental das TDIC e distante das perspectivas autoral, inovadora e empoderadora, defendidas pelo arcabouço teórico elencado neste estudo.

Quanto ao empoderamento, aqui discutido em sua acepção freireana (FREIRE e SHOR, 1986; BAQUERO, 2012; PESCE, 2013a), a análise das entrevistas dos docentes não identifica grandes aproximações com o conceito. Apenas o Prof. Luiz Roberto, curiosamente um dos docentes posicionado em um baixo nível de apropriação tecnológica, faz uso do termo de forma distante do conceito freireano.

O texto do empoderamento eu achei legal. Esse talvez - se eu tiver errado você me fala - mas do empoderamento falava justamente dessa questão da alfabetização. Não sei se 0 texto falava bem isso. Mas a questão da introdução nesse mundo digital e do quanto a exclusão te deixa fora de muitas realidades e tal. Eu acho que foi isso. (Prof. Luiz Roberto) 
Não foi possível, por meio dos dados obtidos por meio das entrevistas, observar mais consistências que garantam ou que refutem o curso de um processo de empoderamento freireano nos docentes do CEEJA. Há apenas alguns indícios sobre a compreensão da transformação que a inclusão digital pode promover junto aos estudantes da EJA, especialmente aqueles mais marginalizados.

[É importante, grifo nosso] Para vida dele, para o dia-dia, para a rotina, porque tudo agora a gente tem informatizado, desde retirar um dinheiro no banco, assistir à televisão, a linguagem agora é tecnológica. A gente é que não está acompanhando, né? Acho que mudaria a rotina mesmo do aluno, acompanharia o dia-dia. Aquele aluno que não tem, aquele aluno que é de uma classe um pouco mais pobre, que não tem acesso à nenhuma, ele é um analfabeto completo, porque ele não está aprendendo o mundo. 0 mundo está muito rápido, a tecnologia está muito rápida. Eu acredito que além daqui, do conteúdo, eu estava falando de conteúdo, além disso, acredito que avançaria na vida - como é que a gente fala? - profissional dele, enfim, social, porque as redes sociais estão aí, influenciam a vida deles e eles influenciam a vida de outros. Se você não tem uma linguagem, se não aprende a lidar com essa linguagem, você está boiando, está mais uma vez marginalizado. É mais uma forma de marginalizar, além das outras. (Prof. ${ }^{\text {a }}$ Silvana)

A fala da docente vai ao encontro da percepção de Takahashi (2005), Sorj e Guedes (2005) e Buzato (2010), para quem a exclusão digital representa mais uma faceta do processo de exclusão social.

Esta percepção sobre a inclusão digital esteve muito presente nas discussões e na bibliografia do curso "Mídias Digitais na Educação de Jovens e Adultos" e é possível percebê-la presente também no discurso da docente Silvana.

A categoria analítica $B$ trata exatamente da correspondência do curso, em relação à fala dos docentes e suas percepções sobre sua pertinência e capacidade de influenciá-los no repensar sobre suas práticas.

\section{CATEGORIA B - Pertinência e aproveitamento do curso "Mídias Digitais na Educação de Jovens e Adultos"}

Para analisar a pertinência e o aproveitamento do curso, foi necessário ouvir as percepções dos docentes e do professor coordenador sobre o papel das TDIC na formação da EJA, sobre os pontos fortes e as fragilidades do curso oferecido e sobre as necessidades de profissionalização docente para implementação das TDIC no contexto do CEEJA. Além disso, foi necessário ouvi-los sobre as noções, conceitos e temas discutidos no curso que ficaram em sua memória, bem como a possibilidade de implementação dentro da realidade do CEEJA. Estes questionamentos estão presentes entre os itens 6 e 10 do roteiro de entrevista semiestruturado (APÊNDICE B). 
Para avaliar a pertinência de uma formação docente, é preciso considerar como o docente, por meio de sua reflexão, percebe seu impacto no processo de aprendizagem do estudante. Ao serem questionados sobre o papel das TDIC na formação dos estudantes adultos, os sujeitos abordaram, entre outros aspectos, a questão da preparação para o mercado de trabalho.

[...] eu acho que quem não está inserido está fora do mundo, está fora do mercado, principalmente do mercado de trabalho. Eu acho que é um ponto chave para nossos alunos: vir aqui para conseguir uma melhor colocação de mercado. [...] Porque a gente pensa assim, o cara que está desempregado com cinquenta, sessenta anos, que não tem o domínio da tecnologia, ele já está fora pela idade, ele está fora pelo desconhecimento. Eu acho que a escola tem esse papel. (Prof. ${ }^{a}$ Rita de Cássia)

Tecnologia é fundamental. Mesmo aqueles que não tem tanta condição financeira hoje se esforça para ter um celular, quer a senha do nosso wifi. Sinal de que reconhece que é importante. A gente tem que incentivar. Se a gente pensar, isso tem relação com a vida pessoal dele, com a felicidade. Tem relação com o emprego dele também, né? (Prof. ${ }^{\text {a Maria) }}$

Então, é o que possibilita a eles como forma de informação, de atividades virtuais, atividades online, né? Os que trabalham, sobretudo, eles trabalham, então, no ambiente de trabalho eles podem, tendo um aparelho, um note ou alguma coisa, lá dentro das possibilidades do trabalho, com auxílio do chefe ou alguma coisa assim, sempre está tentando resolver alguma coisa, fazer um curso. Às vezes até meio quebrado, mas acho que é sempre vantajoso. (Prof. Vinícius)

Ainda que a questão da formação para o mercado de trabalho seja muito presente na realidade da EJA, autores como Alheit e Dausien (2006) e Lima (2007) fazem críticas sobre sua priorização, no contexto da formação de adultos. Da mesma forma, autores como Belloni (1998), Takahashi (2005) e Bonilla (2010), ao tratarem da importância do uso das TDIC, criticam a preocupação excessiva com a inclusão digital como formação de mão de obra para o mercado.

Outra questão apontada pelas docentes Rita de Cássia e Silvana refere-se às possibilidades de promoção da inclusão de pessoas com deficiência ou com dificuldades de aprendizagem por meio do uso das TDIC.

E sem falar de alunos com limitações, né? Alunos com deficiência visual, deficiência auditiva. Acho que as tecnologias são importantes para inserir eles em um contexto que, até então, não seria possível. (Prof. ${ }^{a}$ Rita de Cássia)

Totalmente, incluir em todos os sentidos, não só das limitações físicas e intelectuais, mas principalmente tecnologicamente, porque é o nosso mundo, né? Você vai falar em globalização. Todo mundo quer falar em globalização. Sem falar de tecnologia não está colando, né? (Prof. ${ }^{a}$ Silvana) 
Di Pierro (2008) trata da questão da pluralidade de perfis dos sujeitos da EJA, incluindo nesta pluralidade as pessoas com deficiência. Na medida em que estes sujeitos são e foram no passado, por conta de suas limitações, excluídos do processo de educação escolar, agrupam-se aos trabalhadores, pobres, negros, subempregados, migrantes, imigrantes, mulheres, indígenas, população carcerária e jovens que não tiveram êxito na escola regular, que veem na EJA uma oportunidade de se escolarizarem (ARROYO, 2005).

As contribuições do uso das TDIC para o processo de aprendizagem dos alunos também foram ressaltadas por alguns docentes.

Então, hoje o professor direciona o aluno e ele começa a mostrar, a explorar a internet, podendo fazer a abordagem de vários conteúdos de forma diferenciada, uma forma mais lúdica. Uma aprendizagem que ele não consegue ter durante uma orientação, às vezes ele pode ter com a visualização de uma imagem, um site, uma prática, mesmo que seja visual, ele vai absorver melhor. Então, eu entendo que, a partir disso, houve mais essa familiarização do professor e do aluno em relação aos computadores da escola. Eles passaram a ser mais utilizados. (Prof. Renato)

Dos mais velhos, não é o dia-dia o uso do computador, mas para os jovens é o diadia. Se a gente pudesse aliar sempre a tecnologia ao aprendizado, se tivesse ferramentas para isso, com certeza, acho que avançaria o dobro. A gente conquistaria o aprendizado deles em dobro. (Prof. ${ }^{\text {a }}$ Silvana)

A preocupação de autores como Brito (2006), Okada e Bujokas (2012) e Pesce (2013a) em desconstruir a perspectiva instrumental do uso das TDIC é justamente no sentido de não mais vê-las como um instrumento para simplesmente facilitar a aprendizagem e sim como parte de um novo processo educacional, que transforma a própria relação do homem com o saber (LÉVY, 1999). Desta forma, a visão dos professores sobre a relação entre a tecnologia e o processo de aprendizagem pode ser lida como ainda bastante próxima de um olhar tecnicista.

Ademais, os sujeitos entrevistados tratam da importância da formação de jovens e adultos para as TDIC, levando em conta o papel da escola na construção de uma visão de mundo mais abrangente e conectada às novas dinâmicas contemporâneas.

E o papel da escola, nesse sentido, é mostrar para o aluno que existe um mundo muito complexo, muito amplo e complexo, e que a escola tem que buscar mostrar para esse aluno que de tão grande que é esse universo, esse mundo da informática, da internet, do mundo virtual, que ele tem que ter, a partir da escola, um discernimento de como caminhar nessas pesquisas. Porque ao mesmo tempo em que essa pesquisa é rápida, ela pode não ser tão verdadeira quanto parece ser. Então, a escola, eu acho, tem essa função, ao mesmo tempo em que o mundo da internet esta cada vez mais inerente, cada vez mais interligado. Eu não sei, não consigo imaginar o mundo em que ela deixa de existir, eu consigo imaginar um mundo em que ela se torne muito mais complexa. E a escola, nesse caminho de transição do homem entrando, cada vez mais, para o mundo virtual - porque nós 
estamos em uma fase de transição, eu acredito, a internet está no início daquilo que ela virá a ser no futuro - a escola é fundamental para que todos nós tenhamos uma entrada, digamos assim, nesse mundo, de uma forma um pouco mais inteligente. (Prof. Renato)

$\mathrm{Na}$ EJA hoje eu diria que é fundamental, né? Mesmo porque é fora, né? Não é só aqui. Porque a escola é um ambiente em que poderia ter mais. Mas eu digo que também é importante fora, para que os alunos tenham acesso. As redes sociais, os trabalhos de pesquisa que eles vão fazer em outros lugares. Eu acho que poderia ter mais, como se diz? [...] Mais relação e mais interação. (Prof. ${ }^{a}$ Cláudia)

Eu acho que primeiro é se conectar com o mundo, né? A gente tinha uma visão muito pequena, eu acho, de mundo. $E$ entender que você tem um leque de opções, que você pode buscar conhecimento em qualquer parte do mundo, eu acho que isso é muito importante. Você pensar que você está aqui e você pode de repente consultar uma biblioteca do Cazaquistão. Eu acho que a gente está muito longe dos alunos terem essa curiosidade. Mas eu acho que a prática, utilizar na prática, utilizar várias vezes, ter que utilizar, acaba despertando para uma outra coisa. Porque a ideia é, quando você faz uma pesquisa sobre, sei lá, proteínas, de repente ali ele tenha uma outra dúvida, e isso puxe outra dúvida, e mais outra dúvida. (Prof. ${ }^{\text {a }}$ Rita de Cássia)

Os professores Renato, Cláudia e Rita de Cássia demarcam em suas falas a importância do papel da escola no mundo marcado pelo avanço de um novo universal. Para Lévy (1999), esta novidade situa-se no ciberespaço e modifica a relação do homem com a produção de conhecimento, o que coloca em cheque a organização do sistema educacional como um todo.

Para que a convivência com a cultura digital seja viável, é necessário que haja mudanças no processo de profissionalização docente, a fim de que as TDIC sejam incorporadas à prática professoral. Ao responder o item sete do roteiro de entrevistas, os docentes falam sobre a necessidade de formação continuada sobre o tema.

Formação, com certeza. Com certeza. Porque se as cinco ATPC instigaram dois [professores, grifo nosso], dez ATPC podem instigar seis. Eu vi também o pessoal de biologia instigado, eles também utilizaram os recursos, né? [...] Eu acho que a avaliação aqui devia ser assim: você teve essa formação, e o que você fez a respeito? [...] Mas eu acho que a formação deveria continuar. Ela deve continuar. $\mathrm{E}$ a exigência de utilizar as tecnologias deve ser importante. Deve ser exigida pelo coordenador, pelo gestor. (Prof. ${ }^{a}$ Rita de Cássia)

Acho que [falta] curso. [...] E um ambiente adequado, com profissionais adequados. Porque não é só técnica. É assim: o prazer de você chegar e você também praticar. Eu acho que ainda falta essa parte. Porque você tem aquele curso que você chega lá e aprende isso, você tem a técnica, mas chega na hora de praticar é meia hora, uma hora e você sai dali e não tem aquela continuidade. Daí, se você quiser, como é meu caso, você vai ter que aprender sozinha, você vai buscar sozinha. E às vezes tem coisa assim que não, me faltou aquele item. (Prof. ${ }^{a}$ Cláudia)

Falta mais curso de formação, com certeza, inclusive prático, né? Porque a gente tem os cursos, mas ficam teóricos. Teria que ter mais prática. De que maneira eu 
posso unir o inglês, sem ser o que eu acho que eu posso fazer? Precisa de profissionais tragam essas ideias do que já é feito, unindo a teoria dos cursos com 0 que a gente pode fazer aqui na nossa realidade [...] Tem que ter estudo. Tem que ter a prática, a gente realmente. Não só uma oficina porque você propôs, né? Você pediu e a gente fez. Mas no dia-dia, a gente não consegue arrumar tempo para isso. E talvez, como no meu caso, por pura falta de habilidade mesmo. [...] É formação para a gente melhorar mesmo, porque a gente não tem. Acho que eu e ninguém. Eu estou falando pelos professores, porque ninguém tem. Se você não tivesse trazido, desde o último que você fez, eu não vejo ninguém ter falado que procurou outros cursos parecidos. Teria que ser assim mesmo, de fora para dentro. (Prof. ${ }^{a}$ Silvana)

É, principalmente, como eu falei, a gente ver exemplos, assistir uma aula, uma oficina que usasse tecnologia. A direção teve a ideia de usar os ATPC para fazer umas oficinas, tipo, o professor dando aula pro outro. Eu acho bom. $O$ professor que usa, mostra como. A gente aprende vendo alguém fazer e fazendo. É uma outra ideia para novos exemplos, novos cursos. (Prof. ${ }^{a}$ Maria)

Porque, assim, é aquela coisa de você estar preso à sua base, né? A sua base. $E$ talvez isso elimine muitos problemas de embate em sala de aula seja no EJA ou lá. No nosso caso o embate é talvez uma palavra muito pesada. Mas mesmo no EJA ou na escola regular, eu acho assim, eu preciso entender que vem vindo uma nova formação, uma nova realidade, eu que eu preciso integrar isso. Então eu preciso, nesse sentido que eu falei que preciso sair da caverna, porque eu estou lá nas sombras, né? (Prof. Luiz Roberto)

O correto seria eu fazer uns cursos, né? [...] Acho que a formação é necessária permanentemente, né? Não tem outra possibilidade. Você tem alguns caminhos e a renovação permanente desses caminhos, com cursos, novas formas e novas plataformas. (Prof. Vinícius)

A formação continuada de professores para o uso educacional das TDIC é reconhecidamente relevante, mas não há consenso sobre sua melhor forma. As professoras Cláudia e Silvana, por exemplo, sugerem cursos de formação externos à escola, que ofereçam exemplos de experiências bem-sucedidas. Já a Prof. ${ }^{a}$ Maria, por sua vez, valoriza a troca de experiências entre os docentes da própria escola, reconhecendo as experiências e aproximando-se das proposições de Nóvoa (1995) e Tardif (2014).

Os professores Vinícius e Luiz Roberto, no entanto, destacam a dificuldade em participar de formações fora do horário de trabalho, por conta da rotina docente exaustiva.

O problema, não sei se cabe dizer porque é um caso particular, é que, como eu trabalho em duas instâncias, é meio complicado. Pode ser feito em um fim de semana e tal, mas a gente fica cansado da lide diária, é mais complicado. (Prof. Vinícius)

É assim, eu sei que discurso de professor vira lugar comum, né? A dinâmica muitas vezes acaba limitando bastante. Eu estou falando da dinâmica de vida do professor mesmo. Aquele coisa, sabe? Daria até para fazer alguma coisa, mas também acho que essa não é a discussão. (Prof. Luiz Roberto) 
Essa dificuldade, também discutida por Nóvoa (1995; 1999) e Giroux (1997), traz à tona a discussão sobre a necessidade de maior investimento em políticas de formação docente em horário de serviço, como propõem Aquino e Mussi (2001), Placco (2010) e Cunha e Prado (2010).

Quanto à avaliação que os docentes fazem do curso "Mídias Digitais na Educação de Jovens e Adultos", o quadro abaixo procura sintetizar os pontos fortes e as fragilidades, de acordo com as respostas obtidas por meio da sexta questão do roteiro de entrevistas.

Quadro 9 - Síntese dos pontos fortes e fragilidades do curso "Mídias Digitais na Educação de Jovens e Adultos”, segundo os entrevistados

\begin{tabular}{|c|c|c|}
\hline Docente & Pontos Fortes & Fragilidades \\
\hline $\begin{array}{l}\text { Prof. }^{\text {a }} \text { Rita de } \\
\text { Cássia }\end{array}$ & $\begin{array}{l}\text { "Eu acho que o ponto forte é o instigar. } \\
\text { Eu me senti instigada. [...] Fez com } \\
\text { que a gente falasse: 'não, espera lá, a } \\
\text { gente tem que se sacudir, porque nós } \\
\text { estamos parados aqui'. [...] É } \\
\text { importante você saber o porquê de } \\
\text { você estar discutindo aquilo. } \\
\text { Entendeu? Essa clareza de objetivo, } \\
\text { assim, eu acho bastante importante. Eu } \\
\text { acho que foi bacana." }\end{array}$ & $\begin{array}{l}\text { "O ponto fraco eu acho que é ser } \\
\text { obrigatório para todo mundo. Eu acho que } \\
\text { tem que ter interesse, né? [...] Tem que } \\
\text { ser por adesão. Porque aí você consegue, } \\
\text { de repente, cobrar, você pode ter um } \\
\text { feedback mais significativo, eu acho." }\end{array}$ \\
\hline Prof. ${ }^{a} \mathrm{Cl}$ & $\begin{array}{l}\text { "Abrangeu bem, atingiu bem. } \\
\text { Principalmente porque ajudou a } \\
\text { despertar um monte de ações que } \\
\text { antes não existiam. Não sei se é só o } \\
\text { curso ou se é todo o incentivo que } \\
\text { passou a ter. Eu já fazia, mas muitos } \\
\text { [professores, grifo nosso] não } \\
\text { punham a mão [nas tecnologias, } \\
\text { grifo nosso] e agora começam a por." }\end{array}$ & $\begin{array}{l}\text { "Eu acho que a gente deveria ter colocado } \\
\text { algumas coisas. A teoria é ótima, né? Mas } \\
\text { como eu te falei, até mesmo das questões } \\
\text { do curso, pra gente, a prática. Eu acho que } \\
\text { faltou. [...] Para complementar, faltou a } \\
\text { prática. [...] Precisa ter a coisa da vivência, } \\
\text { de você estar ali tirando suas dúvidas na } \\
\text { hora: é isso ou é aquilo, né?" }\end{array}$ \\
\hline Prof. ${ }^{\text {a }}$ & $\begin{array}{l}\text { "Eu não vou saber te detalhar, mas o } \\
\text { que ficou foi que você trouxe. O que foi } \\
\text { legal? Você começou o trabalho, } \\
\text { assim, da gente pensar nisso, para } \\
\text { fazer essa oficina, por exemplo. Porque } \\
\text { se não ia ser mais uma coisa que ia } \\
\text { ficar para lá. E quando você fez o curso } \\
\text { e sugeriu, a gente já foi pensando, já } \\
\text { teve algumas ideias para unir à } \\
\text { tecnologia ao aprendizado do aluno. } \\
\text { Então, isso ficou, com certeza, a teoria } \\
\text { toda eu não guardei." }\end{array}$ & $\begin{array}{l}\text { "Mas eu acredito que eu senti falta de fazer } \\
\text { a prática de algumas situações que você } \\
\text { colocou. Então, alguns mecanismos, } \\
\text { algumas ferramentas que você colocou } \\
\text { que existiam, eu acredito que eu até fixaria, } \\
\text { eu, pessoalmente, fixaria muito mais se eu } \\
\text { tivesse visto na hora, se alguém levasse } \\
\text { um computador, por exemplo." }\end{array}$ \\
\hline Prof. ${ }^{\text {a Maria }}$ & $\begin{array}{l}\text { "O ponto forte é a iniciativa, o } \\
\text { conhecimento trazido. A gente não leu } \\
\text { tudo. Eu, pelo menos, não li quase } \\
\text { nada. Mas participei das discussões. } \\
\text { Participei do debate, ajudei a pensar } \\
\text { tudo aquilo para nossa realidade aqui. } \\
\text { Porque nem tudo se aplica, né?" }\end{array}$ & $\begin{array}{l}\text { "Teve uma parte prática, né? Mas foi } \\
\text { pouco. E isso que falta, ponto fraco, não } \\
\text { teve a participação, a dedicação total dos } \\
\text { professores, como merecia ter. Faltou ver a } \\
\text { coisa acontecendo, exemplos práticas, } \\
\text { experiências que deram certo. Talvez } \\
\text { desse para fazer aulas de exemplo." }\end{array}$ \\
\hline Prof. Luiz & "Só por você ter um curso e o curso & "Eu acho assim, na verdade, o que \\
\hline
\end{tabular}




\begin{tabular}{|c|c|c|}
\hline Roberto & $\begin{array}{l}\text { estar estruturado - não vou ficar } \\
\text { fazendo elogios. [...] A leitura, o } \\
\text { material que o curso propôs, ele é } \\
\text { muito mais rico do que a gente possa, } \\
\text { sei lá. A discussão poderia ser mais } \\
\text { rica se ela ficasse centrada nesse } \\
\text { material. Então eu não sei como seria o } \\
\text { caminho melhor. [...] Mas acho legal } \\
\text { ter uma nova proposta desse curso. } \\
\text { Seria bom." }\end{array}$ & $\begin{array}{l}\text { compromete um curso como foi esse não é } \\
\text { nem a proposta do curso, é a disciplina de } \\
\text { quem está fazendo em receber o material } \\
\text { antecipadamente e abri-lo e explorá-lo. [...] } \\
\text { Porque como ele é um tema extremamente } \\
\text { atual e muito discutido, as pessoas acham } \\
\text { que dá para, sabe, entrar na discussão } \\
\text { sem essa leitura." }\end{array}$ \\
\hline Prof. Vinícius & $\begin{array}{l}\text { Não, eu acho que o formato foi } \\
\text { interessante. Teve uma parte prática, } \\
\text { né? [...] Mas acho que associar o } \\
\text { estudo de textos, houve estudos de } \\
\text { textos, conhecer os especialistas da } \\
\text { área é importante, as pessoas que } \\
\text { estão aí nos estudos sobre tecnologia } \\
\text { ou sobre o uso das tecnologias, não é } \\
\text { isso? É sempre importante a parte } \\
\text { teórica. E mostrar alguns caminhos, } \\
\text { mas não oferecer respostas, mas } \\
\text { oferecer e mostrar caminhos de } \\
\text { utilização das tecnologias. }\end{array}$ & $\begin{array}{l}\text { "Associar um pouco [com a prática, grifo } \\
\text { nosso], né? Propor, né? Juntamente com } \\
\text { o ensino teórico, com o estudo teórico, } \\
\text { desculpe, umas atividades, mostrar uns } \\
\text { caminhos, plataformas, possibilidades. Eu } \\
\text { acho que o formato foi bastante proveitoso } \\
\text { em tudo que foi feito." }\end{array}$ \\
\hline Prof. Renato & $\begin{array}{l}\text { "O ponto forte que eu avalio } \\
\text { positivamente é que, de certa forma, } \\
\text { nós vencemos muitos obstáculos } \\
\text { desde que iniciou o nosso incentivo ao } \\
\text { uso das tecnologias, ao mundo da } \\
\text { informática, ao mundo virtual, enfim. } \\
\text { Nós temos casos de professores aqui } \\
\text { que há cinco anos atrás não sabia nem } \\
\text { ligar um computador e hoje consegue } \\
\text { sentar na frente dele e digitar, } \\
\text { consegue fazer o mais simples trabalho } \\
\text { da nossa escola, por exemplo, digitar } \\
\text { uma nota no sistema. Quer dizer, foi } \\
\text { positivo, porque nós demos o incentivo } \\
\text { para que muitas pessoas que nem } \\
\text { conseguiam adentrar a esse mundo, } \\
\text { agora deram seus primeiros passos. } \\
\text { [...] Então hoje eles fazem questão de } \\
\text { usar aquela sala, porque aquela sala } \\
\text { está preparada par usar vídeo, usar } \\
\text { outros recursos na oficina, que vão } \\
\text { ajudar na atividade que os alunos vão } \\
\text { fazer depois da apresentação. [...] As } \\
\text { tecnologias ajudaram a fundamentar a } \\
\text { coisa toda. }\end{array}$ & $\begin{array}{l}\text { "Os pontos frágeis, penso assim, acho que } \\
\text { cada professor deveria ter seu notebook } \\
\text { durante a formação. Nem todos têm. O } \\
\text { número de computadores na escola devia } \\
\text { ser maior e o espaço físico também. Assim, } \\
\text { o curso fica prejudicado, porque não dá } \\
\text { para explorar mais isso. [...] Então poucos } \\
\text { alunos, poucos professores, utilizam, } \\
\text { fazem uso dos computadores. Mas isso já } \\
\text { mudou bastante em relação aos anos } \\
\text { anteriores. [...] Falta recurso, falta uma } \\
\text { lousa interativa digital, que para nossa } \\
\text { modalidade de ensino seria interessante, } \\
\text { entendeu? [...]. Então, por exemplo, na } \\
\text { nossa sala de informática nós temos cinco } \\
\text { ou seis computadores, mas, de repente, se } \\
\text { existisse um sinal que o aluno tivesse } \\
\text { acesso, não sei de que forma poderia ser } \\
\text { para ter controle, mas que ele pudesse } \\
\text { trazer sua maquina, seu celular e tablet } \\
\text { para a escola, sentasse no pátio e, enfim, } \\
\text { se ele tivesse acesso sem } \\
\text { necessariamente precisar da sala de } \\
\text { informática." }\end{array}$ \\
\hline
\end{tabular}

Fonte: elaborado pelo autor com base na coleta de dados

Os docentes Vinícius, Maria, Silvana e Cláudia, conforme o quadro, apontam para falta de experiências práticas como a principal fragilidade do curso de formação "Mídias Digitais 
na Educação de Jovens e Adultos". Este dado é bastante relevante, no sentido de contribuir para o avanço de novas experiências de formação docente para o uso das TDIC. Como ensina Tardif (2014), é preciso questionar as lógicas disciplinares dos cursos de formação de professores, abrindo espaço para uma lógica de formação profissional baseada na análise das práticas, das tarefas e dos conhecimentos dos professores de profissão, isto é, na leitura dos respondentes, a falta de atividades práticas e exemplos concretos de uso educacional das TDIC impuseram limites ao processo de formação.

As questões da resistência e desmotivação dos professores aparecem, mais uma vez, entre as fragilidades do curso em tela apontadas por Luiz Roberto e Rita de Cássia. Estas observações apresentam também desafios para o repensar sobre o próprio curso, na medida em que ele não pareceu capaz de mobilizar os docentes, como se propunha a fazer. Ao serem questionadas sobre a adesão dos docentes ao curso, as docentes Rita de Cássia e Silvana complementaram.

Porque existe um certo comodismo de estar aqui, de se achar, prepotente não é bem a palavra, mas achar que não pode, que não precisa melhorar, entendeu? Achar que o que faz é o bastante. [...] Eu nunca acho que faço o bastante. Então, eu quero sempre fazer mais, mais para os meus alunos, pelas dificuldades que eles têm. (Prof. ${ }^{a}$ Rita de Cássia)

De alguns colegas, eu acho que teve um pouco de resistência. Porque a gente vê que alguns colegas resistem ao uso mesmo até para si. Ainda tem professores que resistem. Acho que é um medo de usar o computador, de ensinar para o aluno uma coisa que você não sabe. [...] Mas isso é próprio de escola pública, Bruno. Isso é a cara da escola pública. Alguns professores estão acomodados esperando aposentar. [...] Você sempre vai ter metade envolvida e outra metade não em qualquer situação. [...] É uma prática da escola pública, independente de ser regular ou não. E aqui é um espaço mais fácil, né? Mas nem aqui todas as pessoas se envolvem quando não tem interesse, porque são acomodadas. $E$ aí eu digo que não é o curso que vai mobilizar. Você pode vir aqui e dar aula de cabeça para baixo que as pessoas não vão se interessar, porque não se interessam mesmo, querem ver 0 bonde passar. Eu penso assim. Com raríssimas exceções e são sempre as mesmas pessoas que você vai contar. E são sempre as mesmas pessoas que você tem que cutucar, que são mais acomodadas, né? Não é que não fazem, mas fazem com aquele peso, né? Não curte o que está fazendo. Mas isso é típico da escola pública. (Prof. ${ }^{a}$ Silvana)

As duas falas são representativas do grande desafio de promover formação continuada em serviço, ainda mais exercendo a dupla função de coordenador e formador. Apesar das falas contundentes, para Prof. Renato, que permanecia como professor coordenador deste CEEJA até o momento de aplicação do instrumento de coleta de dados, a resistência vem diminuindo com o avanço das ações de promoção das TDIC entre os docentes. 
Eu acho. Acho que eles estão juntando mais. Todas as atividades que eram feitas sem uso de tecnologias, hoje eles estão mesclando e criando coisas novas. Estão mostrando de uma outra forma agora. Tanto tem aumentado que nós estamos até investindo mais em aparelhos de tecnologia, porque quando usa muito, quebra mesmo. [...] Aquela resistência inicial vem sendo superada. Antes a oficina era escolher um texto legal, uma imagem legal para que os alunos participassem das discussões, das reflexões, agora, depois principalmente dessa formação do ano passado, eles começaram, como eu já falei, a experimentar. Eles fazem o mesmo, mas com maior interação, maior atenção dos alunos. A qualidade do trabalho é a mesma, mas ele é mais próximo do aluno agora. Estou falando a partir do que eu vi e eu vejo. (Prof. Renato)

A fala do professor coordenador Renato, bem como todos os pontos fortes apontados pelos docentes, sugere que o curso serviu para mobilizar parte significativa dos professores para o uso das TDIC. Não se trata, ainda, de abranger a totalidade do corpo docente e muito menos de superar a perspectiva instrumental, mas os dados indicam o início de um processo de incorporação da cultura digital às práticas deste CEEJA, o que, por si só, já é válido como um primeiro passo.

Apesar do considerável avanço, os sujeitos tiveram bastante dificuldade em responder quais noções e temas discutidos no curso ficaram presentes em sua memória. Este dado, por outro lado, é um indicativo de limites para o sucesso das dinâmicas escolhidas para o desenvolvimento da formação.

Olha, eu me lembro muito de uma discussão que a gente teve, da questão do, a gente estava falando sobre a questão das idades e sobre os modos como aprendem as tecnologias e da resistência. [...] Então, eu me lembro muito mais dessa situação. Acho que só. Não sei. Eu só lembro que a gente saia de cada ATPC pensando: "a gente tem que, a gente tem que, a gente tem que, a gente tem que fazer alguma coisa que coloque, que insira essas tecnologias nas nossas avaliações" (Prof. ${ }^{a}$ Rita de Cássia)

Acho que foi aquela do Moran, que fala da - acho que foi você que falou - da questão do uso da tecnologia em sala de aula, né? Do nosso receio de às vezes ter que estar trabalhando com ela. E acho que foi uma última coisa que você colocou, acho que foi o último texto, mas não lembro direito. (Prof. ${ }^{a}$ Cláudia)

Ah, não vou conseguir lembrar. Isolado, assim, não lembro não. Porque conforme você ia falando eu já ia pensando no que ia fazer. A minha memória é péssima para guardar assim. [...] Eu me lembro de uma aula que você deu em que você disse da dificuldade em se garantir direitos autorais, que tudo se compartilha quando joga na internet. [...] Mas falou muito mais que isso. Acho que para mim ficou mais essa parte, porque eu já devo ter associado com fanfiction, já estava aqui numa repartição, num arquivo da memória. (Prof. ${ }^{a}$ Silvana)

Não lembro tudo. Mas claro que fica sempre alguma coisa. Aquele negócio dos recursos abertos. Aquilo é muito bacana. Foi assim que montamos a oficina, 0 simulador, que a gente até já conhecia, mas não tinha pensado como um. Tem muita coisa lá, né? A gente viu. Não vimos tudo, porque é muito e tem que ter tempo de procurar, de fuçar. [...] Assim, toda aquela discussão da desigualdade. Uns com 
acesso, outros sem. Isso marcou porque discutimos com dados, números. [...] A gente está aqui com a pessoa excluída mesmo, já excluída desde criança. Então é preciso levar isso em conta. (Prof. ${ }^{a}$ Maria)

Eu estava no curso, eu acompanhei, eu participei, mas não como eu deveria. Então, na verdade, eu não estou munido. Agora fazendo uma leitura crítica para minha pessoa, aí talvez a iniciativa. Lembra que você me perguntou qual era o maior problema, a maior dificuldade? Talvez o maior problema e a maior dificuldade seja a iniciativa. Porque? 0 que eu retive do curso? A dificuldade que eu estou tendo de buscar o texto e tal. Eu me lembro de temas, me lembro de palavras, mas talvez faltou eu ter essa base para deixar claro: tem que fazer isso, isso e aquilo. Agora, eu analisando a minha falta de iniciativa, ela não pode ser pensada pelo tempo, mas pela falta de base mesmo. Ai vem a pergunta: como é que eu vou trabalhar com 0 outro e tentar alfabetizar introduzir o outro, se a minha base também não está legal? (Prof. Luiz Roberto)

Então, essa questão da inclusão digital é interessante. Porque, não sei, no nosso caso aqui, em nosso tipo de atividade, por incrivel que pareça, a gente ainda encontra pessoas que não tem acesso, que tem dificuldade, às vezes até por uma questão financeira. Então, essa ampliação por esse sistema de conexão aberto, wifi, acesso público. Seria interessante ampliar esse serviço. Um país como o Brasil que em todas as instâncias tem dificuldades, tem limitações. (Prof. Vinícius)

As falas dos seis docentes destacam algumas noções superficiais de temas tratados no curso, como Recursos Educacionais Abertos e inclusão digital. No entanto, nota-se grande dificuldade dos respondentes em resgatá-las de suas memórias e, quando surgem, essas noções são bastante vagas. A distância temporal entre o curso e a realização da entrevista foi de pouco mais de treze meses, o que pode justificar esta dificuldade. Outro fator relevante é a ausência de leituras, conforme relataram os docentes Luiz Roberto, Maria e Silvana.

\subsection{Discussão dos Resultados}

A discussão de resultados ampara-se nos achados da análise documental do plano de curso, do projeto político-pedagógico do CEEJA e dos planos de oficinas elaborados pelos professores, acrescidos da análise temática de conteúdo dos dados obtidos por meio de entrevistas semiestruturada junto a seis docentes e ao professor coordenador do CEEJA.

A análise documental do PPP do CEEJA pesquisado sugere discussões sobre três aspectos:

a) a escola percebe e valoriza a ATPC como um espaço formativo, garantindo a participação de todos os docentes na reunião e favorecendo a troca de experiências;

b) a visão do uso educacional das TDIC ainda é um tanto instrumental, de acordo com o documento, especialmente por compreendê-lo como apoio ao processo de ensino individualizado e coletivo da escola; 
c) a concepção de EJA distancia-se da perspectiva compensatória e aproxima-se do ideal de educação ao longo da vida.

A análise documental do plano de curso "Mídias Digitais na Educação de Jovens e Adultos" indica que a bibliografia sugerida e as estratégias de formação descritas no documento condizem com os pressupostos teóricos da presente pesquisa, especialmente a perspectiva não instrumental do uso das TDIC e a visão do empoderamento (na acepção freireana) de alunos e professores.

A análise documental dos planos de oficina elaborados pelos docentes, ao término do curso, sugere que os docentes foram capazes de relacionar as discussões e leituras propostas no curso com a tarefa de construir um plano que colocasse em prática seus pressupostos. Há uma pluralidade: de um lado, planos que se aproximam mais de uma perspectiva crítica, colaborativa e autoral; de outro, planos ainda bastante restritos à racionalidade instrumental do uso das TDIC.

No que se refere à Categoria A - Nível de apropriação tecnológica dos docentes e empoderamento - da análise temática de conteúdo, os dados obtidos por meio das entrevistas permitem perceber que o nível de apropriação tecnológica é distinto entre os docentes. Apenas um entre os seis entrevistados demonstrou habilidades tecnológicas que se aproximam de uma perspectiva autoral de rompimento com a lógica instrumental e que também evidencia maior aderência ao empoderamento. Há no relato dos docentes indícios de que uma alfabetização em tecnologia ainda frágil vem paulatinamente ocorrendo entre os docentes do CEEJA. Além disso, os dados propiciam avaliar as próprias condições de uso das TDIC na escola pesquisada, isto porque há uma série de dificuldades que se impõem ao docente que pretende fazê-lo, como falta de computadores, limitação de tempo e desmotivação docente. Esses fatores devem ser levados em conta pelas políticas públicas, pela gestão educacional do CEEJA e em novas formações que poderão ocorrer nesta ou em outras escolas.

Os resultados analisados na Categoria B "Pertinência e aproveitamento do curso" sugerem que o curso "Mídias Digitais na Educação de Jovens e Adultos" não atingiu a totalidade de seu objetivo: mobilizar o uso educacional das TDIC a partir da superação da perspectiva instrumental, visando ao empoderamento. Todavia, há indícios que revelam a importância desta formação como encetamento de um processo de mobilização para o uso das TDIC na instituição. Os docentes e o professor coordenador reconhecem a relevância do curso e asseveram como pontos positivos os avanços ocorridos após sua promoção. Além disso, os 
entrevistados percebem as ATPC do curso em análise como momento privilegiado de formação continuada em serviço, o que, por si só, também é uma consequência relevante.

Em relação ao problema de pesquisa, - se e como o curso em tela contribui para o repensar de prática docente, amparada na utilização crítica das TDIC, de modo a empoderar os professores ao situar sua prática docente em uma perspectiva autoral - a discussão dos resultados sugere um desafio: o fortalecimento da fluência tecnológica dos docentes a partir de uma perspectiva crítica e autoral, para que os mesmos possam se empoderar cada vez mais, como autores da sua prática docente.

Este desafio está relacionado às políticas públicas, em primeiro lugar, mas também se relaciona ao cotidiano de cada escola, por meio das formações continuadas em ATPC. As formações, quando consideradas dentro de contextos específicos, como é o caso estudado, tendem a ser mais significativas e capazes de oferecer maiores contribuições para o repensar dos docentes sobre suas práticas.

No tocante às contribuições do curso em tela, a discussão de resultados destaca, portanto, avanços no repensar dos docentes sobre suas práticas, na medida em que há relatos de experiências práticas transformadas ou impulsionadas pelas discussões ocorridas nos cinco encontros promovidos. Estes avanços, entretanto, não decorreram da apropriação dos conceitos e noções trazidos na bibliografia do curso, mas de um movimento de mobilização dos docentes para a preparação de oficinas que fazem uso das TDIC. 


\section{Considerações Finais}

A presente pesquisa desenvolveu-se com o objetivo de verificar se e como o curso de formação "Mídias Digitais na Educação de Jovens e Adultos", realizado em um CEEJA do estado de São Paulo, no ano de 2015, contribuiu para o repensar da prática docente, amparado pela utilização crítica das TDIC, de modo a empoderar os professores, ao situar sua prática em uma perspectiva autoral.

Do ponto de vista teórico, este estudo acentua a preocupação acadêmica e pedagógica em se posicionar na intersecção de três campos educacionais secundarizados e vistos como distantes: formação de professores, uso educacional das TDIC e educação de jovens e adultos. O diálogo entre estes campos, construído ao longo desta dissertação, é uma importante contribuição desta pesquisa.

A revisão de literatura, que selecionou 14 trabalhos sobre o uso das TDIC na educação de jovens e adultos e 25 estudos sobre a formação de professores para o uso das TDIC, entre os anos de 2007 e 2014 constatou a escassez de pesquisas sobre a possibilidade de conciliar a formação docente e o uso das TDIC na EJA. Além disso, a revisão verificou a presença de um número reduzido de trabalhos que apresentam exemplos bem sucedidos de formação docente para o uso das TDIC (BARROS, 2007; BARCELOS, 2011; MACHADO, 2011). Os estudos revisados convergem para o apontamento da necessidade de superação da perspectiva instrumental do uso das TDIC e para a necessidade de avanços na formação inicial e continuada de docentes (TOZETTO, 2008; SANTOS, 2009; LARA, 2011; PROCOPIO, 2011; SCRAINER, 2011; FROZI, 2012).

É possível afirmar que a presente pesquisa corrobora com estes estudos, em três sentidos. Em primeiro lugar, ao se posicionar exatamente na lacuna deixada pelas pesquisas acadêmicas sobre EJA, que, de modo geral, não levam em conta a formação docente para o uso das TDIC, da mesma maneira como as pesquisas sobre formação para uso das TDIC tendem a ignorar os contextos de EJA. Em segundo lugar, este estudo de caso contribui com o campo, ao relatar uma experiência bem sucedida de formação docente para o uso das TDIC, ainda que com limites sobressaltantes, conforme indicado na análise de dados. Há, portanto, uma preocupação grande com a possibilidade de levar o leitor desta dissertação à experiência vicária e a realizar generalizações naturalísticas (ALVEZ-MAZZOTI, 2006; LUDKE e ANDRÉ, 2014), de modo a comparar as experiências formativas e seus desdobramentos no contexto do CEEJA em tela com outras experiências, em contextos semelhantes. Por fim, por 
meio de todo arcabouço teórico mobilizado nos quatro capítulos teóricos, esta pesquisa ratifica a percepção de que a visão técnica e instrumental do uso educacional das TDIC é hegemônica e que ações formativas, a depender do enfoque que se dê, podem se situar como elementos contribuintes para o ideal de superação deste paradigma, na direção de uma visão mais crítica e reflexiva, que posicione o professor em sua perspectiva autoral (BELLONI, 1998; BARRETO, 2002; BRITO, 2006; PRETTO e ASSIS; 2008; PESCE, 2014).

Ao lançar um olhar sobre a formação continuada em serviço de professores da EJA para o uso pedagógico das TDIC, foram tecidas argumentações que sinalizam para um posicionamento aderente à perspectiva crítico-reflexiva (GIROUX, 1997; NÓVOA, 1995; 1999; FREIRE, 2001; 2002; IMBERNÓN, 2000; AZANHA, 2004; TARDIF, 2014). Esta perspectiva sustenta um processo formativo em que as escolas sejam entendidas como espaços de formação de seus profissionais, a partir da reflexão sobre sua prática e concebe o professor como intelectual, que combina a reflexão e a prática. Esta formação tende a ser ainda mais significativa se ocorrer de forma continuada, em serviço e centrada na escola (CANÁRIO, 1999; AQUINO e MUSSI, 2001; PLACCO, 2010; CUNHA e PRADO, 2010), isto é, em diálogo permanente com os contextos escolares e com as demandas coletivas dos docentes.

A pesquisa revalida, ainda, a importância de uma formação específica para professores da EJA, também amparada na perspectiva crítico-reflexiva, que leve em conta as características específicas dos seus estudantes, aspecto-chave para a constituição da identidade e da profissionalização dos docentes da modalidade (RIBEIRO, 1999; DI PIERRO, 2005a; ARROYO, 2006; SOARES, 2008; MOURA, 2009).

Os estudos sobre formação de professores para a EJA são ainda bastante incipientes e estéreis de dados sobre como as práticas de educação de jovens e adultos de fato funcionam e sobre os saberes experienciais dos docentes (VÓVIO, 2010; DI PIERRO, 2010b). É válido considerar a contribuição da presente pesquisa no diálogo com este campo em dois sentidos. O primeiro é a preocupação em desenvolver um curso de formação que levasse em consideração as peculiaridades do aluno jovem e adulto e que valorizasse os saberes e as experiências dos professores cursistas, buscando evitar a simples transposição das práticas da escola regular. O segundo sentido relaciona-se com a interlocução entre as discussões sobre formação docente para o uso das TDIC e a formação docente para a EJA. Há, em ambas, a presença de uma perspectiva política de busca da superação de paradigmas: o uso instrumental das tecnologias e a concepção compensatória da educação de jovens e adultos. 
A perspectiva crítica do uso educacional das TDIC, tal qual propõem Belloni (1998), Pesce (2013a), Pretto e Assis (2008), que visa situar a prática docente em uma perspectiva autoral, é a premissa para a rejeição da égide da racionalidade técnica e instrumental dominante (ADORNO e HORKHEIMER, 1985). É neste olhar que o presente estudo se ampara, ao contribuir para o debate sobre a exclusão/inclusão digital no Brasil, compreendida como uma faceta da própria exclusão social, especialmente de jovens e adultos com baixa escolarização (TAKAHASHI, 2005; SORJ E GUEDES, 2005; BUZATO, 2010).

Neste sentido, amparado pela acepção freireana de empoderamento, esta pesquisa também pretende contribuir para a reflexão sobre o papel do uso educacional das TDIC para a promoção de práticas sociais contribuintes da construção do capital cultural de jovens e adultos com baixa escolarização. O conceito de empoderamento é central nesta pesquisa e perpassou toda a discussão teórica sobre formação docente, uso pedagógico das TDIC e educação de jovens e adultos, de modo a posicioná-la dentro de uma visão emancipadora e capaz de desequilibrar as relações de poder na sociedade (FREIRE e SHOR, 1986; BAQUERO, 2012). Esta discussão contribui para corroborar com a centralidade dos aspectos políticos presentes no campo da EJA e da perspectiva crítica do uso pedagógico das TDIC.

Do mesmo modo, a pesquisa enunciou uma perspectiva de educação de jovens e adultos alicerçada no paradigma da educação ao longo da vida (DI PIERRO, 2005a; ALHEIT e DAUSIEN, 2006; LIMA; 2007), procurando distanciar-se da visão compensatória proposta pelo ensino supletivo (DI PIERRO; 2005a; OLIVEIRA, 2007). Esta visão, que perpassa toda a história da educação de jovens e adultos no Brasil, configura-se como um grande entrave para constituição de uma identidade para modalidade (OLIVEIRA, 2007; DI PIERRO e HADDAD, 2000; 2015). A partir deste olhar, o presente estudo também busca contribuir para a construção paulatina desta identidade, especialmente por descrever e analisar suas especificidades, seus entraves e avanços. Além disso, ao analisar as características da modalidade ofertada pelos CEEJA e ao tratar de experiências formativas junto aos docentes de uma de suas unidades e dialogar com seu cotidiano, o estudo também intenciona contribuir com outros pesquisadores interessados em investigar programas de presença flexível e ensino individualizado destinado a jovens e adultos em processo de escolarização.

A abordagem qualitativa amparou o movimento metodológico da presente dissertação, que se caracteriza como estudo de caso educacional (STENHOUSE apud ANDRÉ, 2005; LUDKE e ANDRÉ, 2014). 
Foram utilizados como instrumentos de coleta de dados a entrevista semiestruturada junto a seis professores cursistas e junto ao atual professor coordenador da escola que, na ocasião, participou do planejamento e da promoção do curso, além de documentos como o projeto político-pedagógico da escola em tela, o plano de curso e os planos das oficinas elaborados pelos docentes cursistas.

Quanto às formas de análise, o presente estudo desenvolveu a análise temática de conteúdo (BARDIN, 1977; TRIVIÑOS, 1987) dos depoimentos emanados nas entrevistas e a análise documental do projeto político-pedagógico do CEEJA em tela, do plano do curso "Mídias Digitais na Educação de Jovens e Adultos" e dos planos de oficinas elaborados pelos docentes no último encontro da formação. Dito de outro modo, as formas de análise concentram-se na análise documental e na análise temática de conteúdo dos depoimentos dos docentes, nas entrevistas semiestruturadas. Esta análise buscou evidenciar o nível de apropriação tecnológica dos docentes que participaram da formação, assim como a pertinência e o aproveitamento que os docentes fizeram do curso, amparada em autores destacados nos capítulos teóricos e nos padrões de competência docente em TDIC estabelecidos pela UNESCO (2009a; 2009b). Também foram salientados os limites e as possibilidades do curso em tela para o repensar dos docentes, envolvidos em uma formação que os situe em uma perspectiva autoral, procurando observar as contradições intrínsecas ao fenômeno investigado.

No que se refere à discussão de resultados, o grupo de docentes participantes do curso em tela, sujeitos da pesquisa, demonstrou possuir diferentes níveis de apropriação tecnológica e diferentes leituras sobre os usos das TDIC, ora percebendo-os a partir de uma perspectiva instrumental, ora de forma mais crítica e autoral. A análise também revela que os pontos fortes do curso contribuíram para mobilizar os docentes do CEEJA na direção do uso efetivo das TDIC nas práticas docentes, o que indicia aproximação com o objetivo do curso.

No tocante aos limites da pesquisa cumpre observar que o CEEJA e o grupo de docentes entrevistados apresentam características sui generis; tal fato faz com que a pesquisa apresente possibilidade de se lidar com generalização naturalística, em que os achados da investigação podem vir a ser transpostos a situações semelhantes à estudada (PESCE e ABREU, 2013). Este, aliás, é um limite característico dos estudos de caso, pois seus resultados não podem ser transpostos a contextos distintos. No entanto, os resultados contribuem para a construção de propostas formativas semelhantes, especialmente nos contextos de EJA, usualmente secundarizada pelas políticas de formação. 
Um grande desafio emana desta pesquisa: é preciso fortalecer a fluência tecnológica dos docentes a partir de uma perspectiva crítica e autoral, para que os mesmos possam se empoderar cada vez mais, como autores da sua prática docente e contribuir para o processo de inclusão digital e o empoderamento de jovens e adultos em escolarização.

Emana também o indício da necessidade de que as políticas públicas voltadas para a formação docente levem em conta as demandas dos próprios professores, para que os contextos específicos de cada escola sejam considerados na formulação dos processos formativos. Essa consideração vale especialmente para o campo da EJA, pela especificidade de seu público, e, mais ainda, do CEEJA, pela especificidade de sua organização. Além disso, os achados desta pesquisa também sublinham a importância da inserção do uso educacional das TDIC nos contextos da EJA, como estratégia de promoção da inclusão digital e, por conseguinte, de inclusão social e do empoderamento de professores e estudantes.

Os limites desta pesquisa residem no impedimento da observação das contribuições do curso em tela nas práticas docentes e na impossibilidade de generalização dos resultados. Tais circunstâncias incidam a uma inquietação: em que medida uma nova formação docente centrada na escola, que ressalte as experiências práticas, conforme apontado pelos sujeitos de pesquisa, promoveria maiores avanços no uso educacional das TDIC, amparado pela perspectiva crítica, de modo a empoderar os professores, ao situar sua prática em uma perspectiva autoral? Esta é uma questão para futuros estudos. 


\section{REFERÊNCIAS}

ADORNO, Theodor. Educação após Auschwitz. In: . Educação e emancipação. Tradução W. L. Maar. Rio de Janeiro: Paz e Terra, 1995, p.119-138.

ADORNO, Theodor; HORKHEIMER, Max. A Dialética do Esclarecimento. Rio de Janeiro: Jorge Zahar, 1985.

ALBERTI, Verena. História Oral: a experiência do CPDOC. Rio de Janeiro: Centro de Pesquisa e Documentação de História Contemporânea do Brasil, 1989.

ALHEIT, Peter e DAUSIEN, Bettina. Processo de formação e aprendizagens ao longo da vida. Educação e Pesquisa. São Paulo, vol.32, n.1, p.177-197, jan/abril 2006. Disponível em: < http://dx.doi.org/10.1590/S1517-97022006000100011 >. Acesso em: 25/11/2015 .

ALONSO, Katia Morosov. Tecnologias da Informação e Comunicação e Formação de Professores: sobre rede e escolas. Educação \& Sociedade, Campinas, v. 29, n.104, p. 747768, out. 2008. Disponível em: 〈http://dx.doi.org/10.1590/S0101-73302008000300006>. Acesso em: 13/03/2016.

ALMEIDA, Maria Elizabeth B. de; SILVA, Maria da Graça Moreira da. Currículo, Tecnologia e Cultura digital: espaços e tempos de web currículo. Revista e-curriculum, São Paulo, v.7, n.1, abr. 2011. Disponível em: $<$ http://revistas.pucsp.br/index.php/curriculum/article/view/5676/4002> Acesso em $12 / 05 / 2016$

AQUINO, Julio Groppa; MUSSI, Mônica Cristina. As vicissitudes da formação docente em serviço: a proposta reflexiva em debate. Educação e Pesquisa. São Paulo, v.27, n.2, p.211227, jul. 2001. Disponível em: <http://www.scielo.br/scielo.php?script=sci_art text\&pid=S151797022001000200002\&lng=en\&nrm=iso >. Acesso em: 11/05/2016

AQUINO, Mirian de Albuquerque; BEZERRA, Lebiam Tamar Silva. Ensinar e aprender na cibercultura. Revista FAMECOS, Porto Alegre, v. 18, n. 3, p. 834-854, set./dez. 2011.Disponível em: <http://revistaseletronicas.pucrs.br/ojs/index.php/revista famecos/article0 /view/10386> Acesso: 29/04/2016.

AMARAL, Luiz Henrique; AMARAL, Carmem Lúcia Costa. Tecnologias de comunicação aplicadas à educação. In: MARQUESI, Sueli Cristina; ELIAS, Vanda Maria da Silva; CABRAL, Ana Lúcia Tinoco (Org.). Interações virtuais: perspectivas para o ensino de Língua Portuguesa a distância. São Carlos: Editora Claraluz, 2008.

AMPARO, Matheus Augusto Mendes; SCHLÜNZEN JUNIOR, Klaus; FURLANETTI, Maria Peregrina de Fátima Rotta. Inclusão digital na educação de jovens e adultos: uma análise em um município do Brasil. In: VI Seminário Luso-Brasileiro Educação, Trabalho e Movimentos Sociais das políticas às lógicas de ação, Lisboa/Portugal. Anais do VI Seminário Luso-Brasileiro Educação, Trabalho e Movimentos Sociais das políticas às lógicas de ação, 2013. p. 39-51. Disponível em: <http://selubet2013.ie.ul.pt/> Acesso em: 13/03/2015. 
ANDERY, Maria Amália . Para compreender a ciência: uma perspectiva histórica. Rio de Janeiro: Garamond, 2007.

ANDRÉ, Marli Eliza Dalmazo Afonso de. Estudo de caso em pesquisa e avaliação educacional. Brasília: Liber Livro Editora, 2005.

A pesquisa sobre formação de professores: contribuições à delimitação do campo. In: DALBEN, Ângela et al. Didática: convergências e tensões no campo da formação e do trabalho docente. Belo Horizonte: Autêntica, 2010a.

A formação de professores: a constituição de um campo de estudos. Educação, Porto Alegre, v. 33, n. 3, p. 174-181, set./dez. 2010b. Disponível em <http://revistaseletronicas.pucrs.br/ojs/index.php/faced/article/ view/8075>. Acesso em 02/08/2015.

ARROYO, Miguel Gonzáles. Formação de educadores e educadoras de jovens e adultos. In: SOARES, Leôncio. (org.) Formação de educadores de jovens e adultos. Brasília: MEC/SECAD/Unesco; Belo Horizonte, Autêntica, 2006. p. 17-33. Disponível em < http://unesdoc.unesco.org/images/0014/001493/149314porb.pdf>. Acesso em 11/05/2016.

Educação de jovens e adultos: um campo de direitos e de responsabilidade pública. In: SOARES, Leôncio; GIOVANETTI, Maria Amélia; GOMES, Nilma (orgs.) Diálogos na Educação de Jovens e Adultos. Belo Horizonte: Autêntica, $1^{a}$ edição, 2005. p. 19-50.

ASSMANN, Hugo. Redes Digitais e Metamorfose do Aprender. Petrópolis, RJ: Vozes, 2005.

AZANHA, José M. P. Uma reflexão sobre a formação do professor da escola básica. Educação e Pesquisa, São Paulo, v.30, n.2, p.369-378, ago. 2004. Disponível em: $<\mathrm{http}$ //www.scielo.br/scielo.php?script=sci_arttext\&pid=S151797022004000200016\&lng=en \&nrm=iso>. Acesso em: 02/08/2015.

2006.

. A Formação do Professor e Outros Escritos. São Paulo: Editora Senac,

BAQUERO, Rute. Empoderamento: instrumento de emancipação social? Uma discussão conceitual. Revista Debates, Porto Alegre, v. 6, n. 1, p.173-187, jan./abr. 2012. Disponível em: < http://seer.ufrgs.br/debates/article/view/26722> Acesso em 07/05/2016.

BARDIN, Laurence. Análise de conteúdo. Lisboa: Edições 70, 1977.

BANDEIRA, Alexandre. O conceito de tecnologia sob o olhar do filósofo Álvaro Vieira Pinto. Geografia, Ensino e Pesquisa, Santa Maria, Rio Grande do Sul, v. 15, n. 1, jan./abr. 2011. Disponível em: <https://periodicos.ufsm.br/geografia/article/viewFile/7381/4420> Acesso em 04/10/2016.

BARCELOS, Gilmara Teixeira. Tecnologias na prática docente de professores de matemática: formação continuada com apoio de uma rede social na internet. Porto Alegre: UFRGS, 2011, 332f., Tese (Doutorado em Informática Educação) - Programa de PósGraduação em Informática na Educação, Centro Interdisciplinar de Novas Tecnologias na 
Educação, Universidade Federal do Rio Grande do Sul, Porto Alegre, 2011. Disponível em: <http://www.lume.ufrgs.br/handle/10183/48918> Acesso: em 11/05/2016

BARRETO, Raquel Goulart. Formação de Professores, tecnologias e linguagens. São Paulo:Edições Loyola, 2002.

BARROS, Daniela Melaré Vieira. Formação continuada para docentes do ensino superior: o virtual como espaço educativo. Revista Diálogo Educacional. Curitiba, v. 7, n.20, p.103-122, jan./abr. 2007. Disponível em: < http://www2.pucpr.br/reol/pb/index.

php/dialogo?dd1=559\&dd99=view\&dd98=pb> Acesso em 11/05/2016.

BELLONI, Maria Luiza. Tecnologia e formação de professores: rumo a uma pedagogia pósmoderna? Educação e Sociedade. Campinas, v.19, n.65, dez. 1998. Disponível em: <http://dx.doi.org/10.1590/S0101-73301998000400005> Acesso em: 29/04/2016.

BEISIEGEL, Celso. Paulo Reglus Neves Freire. In: FÁVERO, M. de Lourdes de A.; BRITTO, J. de M.. (Orgs.). Dicionário de educadores no Brasil da colônia aos dias atuais. Rio de Janeiro: UFRJ/MEC/INEP, 1999, p. 440-446.

BRITO, Bianca Maria Santana. Jovens e Adultos em Processo de escolarização e as tecnologias digitais: quem usa, e a favor de quem e para quê? São Paulo: USP, 2010, 121f., Dissertação (Mestrado em Educação) - Programa de Pós-Graduação em Educação, Faculdade de Educação, Universidade de São Paulo, São Paulo, 2010. Disponível em: < http://www.teses.usp.br/teses/disponiveis/48/48134/tde-01102012-103931/pt-br.php> Acesso em: 29/04/2016.

BRITO, Glaucia. A Inclusão Digital do Profissional Professor: entendendo o conceito de tecnologia. Anais do $30^{\circ}$ Encontro Anual da ANPOCS. Associação Nacional de PósGraduação e Pesquisa em Comunicação Social, Caxambu, MG, out. 2006. Disponível em<http://portal.anpocs.org/portal/index.php?option=com_docman\&task=doc_view\&gid=34 75\&Itemid=232> Acesso em 11/05/2016

BRZEZINSKI, Iria. Políticas contemporâneas de formação de professores para os anos iniciais do ensino fundamental. Educação e Sociedade. Campinas, v. 29, n. 105, p. 11391166, set./dez. 2008. Disponível em: 〈http://dx.doi.org/10.1590/S0101-73302008000400010> Acesso em 12/05/2016.

BOGDAN, Robert e BIKLEN, Sari. Investigação qualitativa em educação: uma introdução à teoria e aos métodos. Porto, Portugal: Porto Editora, 1994.

BONILLA, Maria Helena Silveira. Inclusão digital nas escolas. In: PINHEIRO, Antonio Carlos Ferreira; ANANIAS, Mauricéia (Org.). Educação, direitos humanos e inclusão social: histórias, memórias e políticas educacionais. João Pessoa: Editora universitária da UFPB p. 183-200. (v. 2), 2009.

Políticas Públicas para Inclusão Digital nas Escolas. Metrovivência. Florianópolis, SC, ano XXII, n. 34, p. 40-60, jun. 2010. Disponível em: $<$ https://periodicos.ufsc.br/index.php/motrivivencia/article/download/17135/15840> Acesso em $12 / 05 / 2016$. 
BUCKINGHAM, David. Cultura digital, educação midiática e o lugar da escolarização. Educação e Realidade, Porto Alegre, v. 35, n. 3, p. 37-58, set./dez., 2010. Disponível em: <http://seer.ufrgs.br/educacaoerealidade/article/view/13077> Acesso em 12/05/2016.

BUZATO, Marcelo El Khouri. Letramento digital abre portas para o conhecimento. EducaRede, Entrevista por JOFFILY, Olivia Rangel, jan. 2003. Disponível em: <www.educarede.org.br> Acesso em 07/07/2015.

Inclusão digital como invenção do quotidiano: um estudo de caso. Revista Brasileira de Educação. vol.13, n.38, p. 325-342, maio/ago. 2008. Disponível em: <http://dx.doi.org/10.1590/S1413-24782008000200010.> Acesso em 12/05/2016.

. Cultura digital e apropriação ascendente: apontamentos para uma educação 2.0. Educação em Revista, Belo Horizonte, v. 26, n.03, p. 283-304, dez. 2010. Disponível em: <http://dx.doi.org/10.1590/S0102-46982010000300014> Acesso em 11/03/2016.

CAMPERO, Carmen. La formación de los educadores y educadoras de personas jóvenes y adultas en Latinoamérica: aportes desde la investigación y la experiencia. Brasília, Revista Brasileira de Estudos Pedagógicos, v. 96, n. 244, p.501-527, set./dez. 2015. Disponível em: <http://www.scielo.br/pdf/rbeped/v96n244/2176-6681-rbeped-96-244-00501.pdf> Acesso em $11 / 05 / 2016$.

CANÁRIO, Rui. A escola: o lugar onde os professores aprendem. In: MOREIRA, A. et al. Supervisão na formação. Aveiro: Universidade, 1999.

Centros de formação das associações de escolas: Que futuro? In: AMIGUINHO, Abílio; CANÁRIO, Rui (orgs.). Escolas e mudança: o papel dos centros de formação. Lisboa: Educa, 1994. p. 13-58.

CANTINI, Marcos Cezar. Políticas públicas e formação de professores na área de tecnologias da informação e comunicação - TIC na rede pública estadual do Paraná. Curitiba: PUC-PR, 2008, 156f., Dissertação (Mestrado em Educação) - Programa de Pós-Graduação em Educação, Centro de Teologia e Ciências Humanas, Pontifícia Universidade Católica do Paraná, Curitiba, 2008. Disponível em: < http://livros01.livrosgratis.com.br/cp061568.pdf> Acesso em: 03/02/2016.

CARVALHO, Marcelo Pagliosa. O financiamento da EJA no Brasil: repercussões iniciais do FUNDEB. In: Anais do IV Congresso Ibero Americano de Política e Administração da Educação, 2014, Porto,Portugal. IV Congresso Ibero Americano de Política e Administração da Educação, 2014. Disponível em: <http://anpae.org.br/IBERO_AMERICANO_IV/index.html> Acesso em: 03/02/2016

CARVALHO, Maurílio. Tecnologia da informação e da comunicação (TIC) e ensinoaprendizagem de língua portuguesa: implicações na formação do professor. Taubaté: Universidade de Taubaté, 2012, 228f., Dissertação (Mestrado em Linguística Aplicada) Programa de Pós-Graduação em Linguística Aplicada, Departamento de Ciências Sociais e Letras, Universidade de Taubaté, Taubaté, 2012. Disponível em: 
<http://www.acervodigital.unesp.br/bitstream/123456789/45825/6/2ed_ing_m3d6.pdf> Acesso em: 02/08/2015.

COELHO, Lívia Andrade. As relações dos alunos da EJA com as tecnologias digitais: implicações e possibilidades na vida de cada um. Salvador: UFBA, 2011, 133f., Dissertação (Mestrado em Educação), Programa de Pós-Graduação em Educação, Faculdade de Educação, Universidade Federal da Bahia, Salvador, 2011. Disponível em: $<$ https://repositorio.ufba.br/ri/bitstream/ri/9254/1/> Acesso em: 02/08/2015.

COLLARES, Cecília; MOISÉS, Maria Aparecida; GERALDI, João Wanderley. Educação continuada: A política da descontinuidade. Educação e Sociedade, Campinas, ano XX, $\mathrm{n}^{\mathrm{o}}$ 68, p. 202-219. dez. 1999. Disponível em: <http://cev.org.br/biblioteca/educacao-continuadapolitica-descontinuidade/> Acesso em: 12/05/2016.

COLL, César; MONEREO, Carlos. Psicologia da educação virtual: aprender e ensinar com as tecnologias da informação e da comunicação. Porto Alegre: Artmed, 2010.

CORD, Deisi; MELO, S. M. M. . A produção de conteúdo - vídeo - em Tecnologia Digital de Informação e Comunicação (TDIC): um recurso pedagógico no trabalho com uma turma de alfabetização da Educação de Jovens e Adultos. In: Congresso Ibero-Americano de Ciência, Tecnologia, Inovação e Educação, 2014, Buenos Aires, Argentina, 2014. Disponível em: $<$ http://www.oei.es/congreso2014/memoriactei/788.pdf

>Aceso em: 07/12/2015

COSTA, Célio Juvenal; MENEZES, Sezinando Luiz A educação no Brasil Colonial (15491759). In: Fundamentos históricos da educação no Brasil /ROSSI, Ednéia Regina; RODRIGUES, Elaine; NEVES, Fátima Maria (orgs.). 2. ed.,Maringá: Eduem, 2009.

CRUZ, Regina Maria Ribeiro. Limites e possibilidades das tecnologias na educação de jovens e adultos. Belo Horizonte: CEFET-MG, 2008, 185 p., Dissertação (Mestrado em Educação Tecnológica), Programa de Pós Graduação em Educação tecnológica, Centro Federal de Educação Tecnológica de Minas Gerais, Belo Horizonte, 2008. Disponível em: $<$ http://31reuniao.anped.org.br/1trabalho/GT18-5049--Int.pdf> Acesso em: 14/11/2015.

CUNHA, Renata C. O. B.; PRADO, Guilherme do V. T. Formação centrada na escola, desenvolvimento pessoal e profissional de professores. Revista de Educação PUC-Campinas, Campinas, n.28, p.101-111, jan./jun., 2010. Disponível em: <http://periodicos.puccampinas.edu.br/seer/index.php/reveducacao/article/view/79> Acesso em: 07/12/2015.

CUNHA, Adriana dos Santos; TEODORO, António. A prática pedagógica nos CEEJA da rede estadual de ensino de São Paulo: a abordagem da política educacional e sua reconfiguração no desenvolvimento do trabalho docente. In: Atas do $V$ Seminário Nacional Formação de Educadores de Jovens e Adultos. Faculdade de Educação, UNICAMP, Campinas, SP, 2015. Disponível em: $<$ http://sistemas3.sead.ufscar.br/snfee/ index.php/snfee/article/view/165> Acesso em: 12/05/2016.

DEMO, Pedro. Inclusão digital - cada vez mais no centro da inclusão social. Inclusão Social, Brasília, v. 1, n. 1, p. 36-38, out./mar. 2005. Disponível em: <http://repositorio. unb.br/handle/10482/9652> Acesso em: 29/04/2016 
DIAS, Lia Ribeiro. Inclusão digital como fator de inclusão social. In: PRETO, Nelson; BONILLA, Maria Helena (orgs.). Inclusão digital: polêmica contemporânea. Salvador: EDUFBA, 2011. p. 61-90.

DI PIERRO, Maria Clara; JOIA, Orlando; RIBEIRO, Vera Masagão. Visões da Educação de Jovens e Adultos no Brasil. Caderno Cedes, Campinas, ano XXI, n. 55, p. 58-77, 2001. Disponível em: <http://dx.doi.org/10.1590/S0101-32622001000300005> Acesso em: 12/05/2016.

DI PIERRO, Maria Clara; HADDAD, Sérgio. Escolarização de jovens e adultos. Revista Brasileira de Educação, Rio de Janeiro, n.14, p.108-130, maio/ago. 2000. Disponível em: <http://www.scielo.br/pdf/rbedu/n14/n14a07> Acesso em: 07/12/2015.

.Transformações nas políticas de educação de jovens e adultos no Brasil no início do terceiro milênio: uma análise das agendas nacional e internacional. Caderno Cedes, Campinas, v. 35, n. 96, p. 197-217, maio/ago., 2015. Disponível em: $<$ http://www.scielo.br/pdf/ccedes/v35n96/1678-7110-ccedes-35-96-00197.pdf> Acesso em: $12 / 05 / 2016$.

DI PIERRO, Maria Clara. Notas sobre a redefinição da identidade e das políticas públicas de educação de jovens e adultos no Brasil. Educação e Sociedade, Campinas, vol. 26, n. 92, p.1115-1139, 2005a. Disponível em: 〈http://www.scielo.br/pdf/es/v26n92/v26n92a18.pdf> Acesso em: 07/12/2015

. Um balanço da evolução recente da educação de jovens e adultos no Brasil. In: Construção coletiva: contribuições à educação de jovens e a adultos. Brasília: UNESCO, MEC, RAAAB, 2005b.

. Educação de jovens e adultos na América Latina e Caribe: trajetória recente. Cadernos de Pesquisa. São Paulo, v.38, n.134, p.367-391, ago. 2008. Disponível em: <http://www.scielo.br/pdf/cp/v38n134/a0638134.pdf> Acesso em: 10/04/2016.

. A Educação de Jovens e Adultos no Plano Nacional de Educação: avaliação, desafios e perspectivas. Educação e Sociedade. Campinas, v.31, n. 112, p 939-959, jul./set. 2010a. Disponível em: <http://www.scielo.br/pdf/es/v31n112/15.pdf> Acesso em: $12 / 05 / 2016$.

Balanço e perspectivas da pesquisa sobre formação de educadores/as de jovens e adultos. In: Anais do III Seminário Nacional Formação de educadores de educação de jovens e adultos, 2011, Porto Alegre. Formação de educadores de educação de jovens e adultos: anais. Porto Alegre: Deriva, 2010b. p. 166-177. Disponível em: <http://forumeja.org.br/sites/forumeja.org.br/files/3_snf_poa.pdf> Acesso em: 12/05/2016.

ENGUITA, Mariano F. Ambiguidade da docência: entre o profissionalismo e a proletarização. Teoria \& Educação, Porto Alegre, vol. 4, p. 41-61, 1991.

FERNANDES, Janira Rodrigues. A integração das tecnologias da informação e comunicação ao currículo no PROEJA. São Paulo: PUC, 2012, 329f., Tese (Doutorado em Educação: Currículo), Programa de Pós-Graduação em Educação: Currículo, Pontifícia Universidade Católica de São Paulo, São Paulo, 2012. Disponível em: 
<http://www.sapientia.pucsp.br/tde_busca/arquivo.php?codArquivo=14644> Acesso em $07 / 12 / 2015$.

FLECHA, Ramón. La Pedagogia de la Autonomía de Freire y la educación democrática de personas adultas. Revista Interuniversitaria de Formación del Profesorado, vol. 18, n. 2, Zaragoza, Espanha, p. 27-43, 2004. Disponível em: <http://www.redalyc.org/articulo. oa? id=27418203> Acesso em 12/05/2016.

FLÔRES, Eneida da Silva. O uso da TV e do computador nas práticas docentes de Língua Portuguesa na educação de jovens e adultos. Maceió: UFAL, 2011, 150f., Dissertação (Mestrado em Educação Brasileira), Programa de Pós-Graduação em Educação, Centro de Educação, Universidade Federal de Alagoas, Maceió, 2011. Disponível em: <http://www.ufal.edu.br/unidadeacademica/cedu/pos-graduacao/mestrado-e-doutorado-emeducacao/dissertacoes/2008/eneida-da-silva-flores/at_download/file> Acesso em: 29/04/2016.

PORTAL FORUNS DE EJA, 2016. Disponível em: <http://www.forumeja.org.br/> Acesso em 12/05/2016.

FREIRE, Paulo. Pedagogia da Autonomia: saberes necessários à prática educativa. São Paulo: Paz e Terra, 2001.

. Pedagogia do Oprimido. Rio de Janeiro: Paz e Terra, 2002.

Terra, 1986.

. ; SHOR, Ira. Medo e Ousadia: o cotidiano do professor. Rio de Janeiro: Paz e

FREIRE, Paulo; HORTON, Myles. O caminho se faz caminhando: conversas sobre educação e mudança social. São Paulo: Vozes. 2003

FREITAS, Marcos Cézar de; BICCAS, Maurilane de Souza. Educação de Adolescentes, jovens e asultos analfabetos. História Social da Educação no Brasil (1926-1996). São Paulo: Cortez, 2009.

FREITAS, Maria Teresa. Letramento digital e formação de professores. Educação em Revista. Belo Horizonte, v. 26, n. 3, dez. 2010. Disponível em: <http://www.scielo.br/pdf/edur/v26n3/v26n3a17.pdf> Acesso em: 12/05/2016.

FROZI, Valtrícia Lucelita. De contextos do fazer pedagógico: entre formação continuada e tecnologias da informação e comunicação. Cuiabá: UFMT, 2012, 138f., Dissertação (Mestrado em Educação) Programa de Pós-Graduação em Educação, Instituto de Educação, Universidade Federal do Mato Grosso, Cuiabá, 2012. Disponível em: <http://www.ie.ufmt.br/ppge/dissertacoes/index.php?op=download\&id=390> Acesso em: 12/05/2016.

GATTI, Bernadete Angelina; SÁ BARRETO, Elba Siqueira de. Professores do Brasil: impasses e desafios. Brasília: Unesco, 2009.

GATTI, Bernadete Angelina; SÁ BARRETO, Elba S.; ANDRE, Marli. Políticas docentes no Brasil: um estado da arte. Brasília: Unesco, 2011. 
GIL, Antonio Carlos. Como elaborar projetos de pesquisa. 4. ed. São Paulo: Atlas, 2002.

GIROUX, Henry. A. Os professores como intelectuais: rumo a uma pedagogia crítica da aprendizagem. Trad. D. Bueno. Porto Alegre: ArtMed, 1997.

GONÇALVES, Becky Henriette. $O$ uso do computador, a alfabetização e a pósalfabetização: o que dizem educandos/as do MOVA. São Carlos: UFSCar, 2007, 172 p., Dissertação (Mestrado em Educação), Programa de Pós-Graduação em Educação, Centro de Educação e Ciências Humanas, Universidade Federal de São Carlos, São Carlos, 2007. Disponível em: <http://www.bdtd.ufscar.br/htdocs/tedeSimplificado/tde_arquivos/8/ TDE-2007-02-26T15:11:02Z-1349/Publico/DissBHG.pdf> Acesso em 12/05/2016.

GONTIJO, Cynthia Rubia Braga. Tecnologias de informação e comunicação na educação de jovens e adultos. Belo Horizonte: CEFET-MG, 2008, 185 p., Dissertação (Mestrado em Educação Tecnológica), Programa de Pós-Graduação em Educação Tecnológica, Centro Federal de Educação Tecnológica de Minas Gerais, Belo Horizonte, 2008. Disponível em: <http://portal.mec.gov.br/setec/arquivos/pdf3/tcc_tecnologias.pdf> Acesso em: 12/05/2016

. ; OLIVEIRA, Maria Rita Neto Sales. Vozes docentes e discentes sobre condições, objetivos e contribuições do uso das TICs na EJA. In: I Seminário Nacional de Educação Profissional e Tecnológica, 2008, Belo Horizonte-MG. CD-ROM do I Seminário Nacional de Educação Profissional e Tecnológica. Belo Horizonte: CEFET-MG, v. 1, 2008. Disponível em: < http://www.senept.cefetmg.br/galerias/Arquivos_

senept/anais/terca_tema6/TerxaTema6Artigo2.pdf> Acesso em 29/04/2016.

GOULART, Denise. Inclusão digital na terceira idade: a virtualidade como objeto e reencantamento da aprendizagem. Porto Alegres: PUCRS, 2007, 196 p., Dissertação (Mestrado em Educação), Programa de Pós-Graduação em Educação, Pontifícia Universidade Católica do Rio Grande do Sul, Porto Alegre, 2007. Disponível em: <http://tede.pucrs.br/tde_busca/arquivo.php?codArquivo=1043> Acesso em 12/05/2016.

GOUVEA, Andrea Barbosa. Políticas e Financiamentos na EJA: as mudanças na política de financiamento da educação e possíveis efeitos na EJA. EccoS - Revista Científica, São Paulo, v. $10, \quad$ n. $2, \quad$ p. 379-395, 2008. Disponível em: < http://www.redalyc.org/articulo.oa?id=71511645006> Acesso em 12/05/2016.

HIDALGO, Sivonei. A educação de jovens e adultos no município de Curitiba sob a ótica de gênero e tecnologia. Curitiba: UTFPR, 2007, 197 p., Dissertação (Mestrado em Tecnologia) Universidade Tecnológica Federal do Paraná, Curitiba, 2007. Disponível em: <http://files.dirppg.ct.utfpr.edu.br/ppgte/dissertacoes/2007/ppgte_dissertacao_223_

2007.pdf> Acesso em 29/04/2016

IGLESIAS, Sandra Letícia Schroeder. A formação do pedagogo e as tecnologias educacionais: realidade ou ficção? Curitiba: PUC-PR, 2012, 150f. Dissertação (Mestrado em Educação) - Programa de Pós-Graduação em Educação, Pontifícia Universidade Católica do Paraná, Curitiba, 2012. Disponível em: $<$ http://www.biblioteca.pucpr.br/tede/tde_busca/arquivo.php?codArquivo=2275> Acesso em 12/05/2016. 
IMBERNÓN, Francisco. Formação docente e profissional. 3.ed. São Paulo: Cortez, 2000.

KENSKI, Vani M. Novas Tecnologias na Educação presencial e a distância I. In.: Formação de Educadores: desafios e perspectivas. Org. Raquel Lazzari Leite Barbosa. São Paulo: Editora UNESP, 2003.

KLAMMER, Celso Rogério. Formação continuada para a prática docente no paradigma da complexidade com uso das tecnologias da informação e comunicação. Curitiba: PUC-PR, 2011. 303f. Tese (Doutorado em Educação) - Programa de Pós-Graduação em Educação, Pontifícia Universidade Católica do Paraná, Curitiba, 2011. Disponível em: <http://www.pucpr.br/posgraduacao/educacao/tesesdissertacoes.php> Acesso em 29/04/2016.

LAFFIN, Maria Hermínia Lage Fernandes; GAYA, Sidneya Magaly. Pesquisas e estudos sobre a formação inicial docente no campo da Educação de Jovens e Adultos. Revista Brasileira de Educação de Jovens e Adultos, Salvador, Bahia, vol. 1, n. 1, 2013. Disponível em: <http://www.revistas.uneb.br/index.php/educajovenseadultos/article/ view/256> Acesso em 12/05/2016

LARA, Rafael da Cunha. Impressões digitais entre professores e estudantes: um estudo sobre o uso das TIC na formação inicial de professores nas universidades públicas de Santa Catarina. Florianópolis: UDESC, 2011, 154f., Dissertação (Mestrado em Educação) Programa de Pós-Graduação em Educação, Centro de Ciências Humanas e da Educação, Universidade do Estado de Santa Catarina, Florianópolis, 2011. Disponível em: <http://www.faed.udesc.br/arquivos/id_submenu/151/rafael_da_cunha_lara.pdf> Acesso em 29/04/2016.

LAVILLE, C.; DIONNE, J. A construção do saber: manual de metodologia de pesquisa em ciências humanas. Porto Alegre: Artmed, 1999.

LAVINAS, Lena; VEIGA, Alinne. Desafios do modelo brasileiro de inclusão digital pela escola. Cadernos de Pesquisa. São Paulo, vol. 43, n. 149, maio 2013. Disponível em: <http://dx.doi.org/10.1590/S0100-15742013000200009> Acesso em 12/05/2016.

LÉVY, Pierre. Cibercultura. São Paulo: Editora 34, 1999.

LIMA, Licinio. Educação ao Longo da Vida: entre a mão direita e a mão esquerda de Miró. São Paulo, Cortez, 2007.

LOPES, Rosana Pereira. Um novo professor: novas funções e novas metáforas. In: ASSMANN, Hugo. Redes Digitais e Metamorfose do Aprender. Petrópolis, RJ: Vozes, 2005.

LOPES, Rosemara Perpétua; FURKOTTER, Monica. Formação para o Uso das Tecnologias Digitais de Informação e Comunicação (TDIC) nas Licenciaturas Presenciais das Universidades Estaduais Paulistas. In: $33^{a}$ Reunião Anual da ANPEd, 2010, Caxambu. Anais da 33 ${ }^{a}$ Reunião Anual da ANPEd - Educação no Brasil: o balanço de uma década. Rio de Janeiro: Associação Nacional de Pós-Graduação e Pesquisa em Educação - ANPEd, 2010. v. 33. p. 01-17. Disponível em: $<$ http://33reuniao.anped.org.br/33encontro/app/webroot/files/file/Trabalhos\%20em\%20PDF/ GT08-6288--Int.pdf> Acesso em 13/03/2016. 
LUDKE, Menga \& ANDRÉ, Marli E.D.A. Pesquisa em educação: abordagens qualitativas. São Paulo: Editora Pedagógica e Universitária, 2014.

LUNA, Sergio Vasconcelos. Planejamento de pesquisa: uma introdução. $2^{\mathrm{a}}$ edição. São Paulo: EDUC, 2009.

MACHADO, Lisandro Lemos. Informática educativa: elementos para uma proposta de formação continuada de professores. Passo Fundo: Universidade de Passo Fundo, 2011, 152f., Dissertação (Mestrado em Educação) - Programa de Pós-Graduação em Educação, Faculdade de Educação, Universidade de Passo Fundo, 2011. Disponível em: $<$ https://secure.upf.br/tede/tde_busca/arquivo.php?codArquivo=549> Acesso em 29/04/2016.

MAIA, Hélio José dos Santos. Formação para o ensino de ciências e o uso de tecnologias da informação e comunicação, um estudo de caso. Brasília: UnB, 2011, 110f., Dissertação (Mestrado em Ensino de Ciências) - Programa de Pós-Graduação em Ensino de Ciências, Instituto de Ciências Biológicas, Instituto de Física, Instituto de Química, Universidade de Brasília, Brasília, 2011. Disponível em: <http://repositorio.unb.br/handle/10482/8652> Acesso em 29/04/2016.

MARTINS, José de Souza. Exclusão social e nova desigualdade. São Paulo: Paulus, 2009.

MATTAR, João. Web 2.0 e Redes Sociais na Educação. São Paulo: Artesanato Educacional, 2013.

MATTOS, Fernando Augusto Mansor de; CHAGAS, Gleison José do Nascimento. Desafios para a inclusão digital no Brasil. Revista Perspectivas em Ciência da Informação. Belo Horizonte, v. 13, n.1, p. 67-94, 2008. Disponível em: $<$ http://portaldeperiodicos.eci.ufmg.br/index.php/pci/article/view/186/392> Acesso em 12/05/2016.

MILHOMEM, André Luiz Borges. A formação inicial de professores nos cursos de licenciatura do campus universitário Jane Vanini - UNEMAT/Cáceres-MT em relação ao uso do computador na educação básica. Cáceres/MT: UNEMAT, 2012, 167f., Dissertação (Mestrado em Educação) - Programa de Pós-graduação em Educação, Faculdade de Educação, Universidade do Estado de Mato Grosso, Cáceres/MT, 2012.Disponível em: $<$ http://portal.unemat.br/media/oldfiles/educacao/docs/dissertacao/ 2012/andre_luiz_borges_milhomem.pdf> Acesso em 04/12/2015.

MOURA, Tania Maria de Melo. Formação de Educadores de Jovens e Adultos: realidade, desafios e perspectivas atuais. Práxis Educacional, Vitória da Conquista, v. 5, n. 7, p. 45-72, jun./dez., 2009. Disponível em: <http://periodicos.uesb.br/index.php/praxis/article/ view/242> Acesso em 29/04/2016.

NÁPOLES, Neusa Nogueira. O uso das tecnologias da informação e comunicação na educação de jovens e adultos: visão de alunos e professores de uma escola municipal de Belo Horizonte. Belo Horizonte: CEFET-MG, 2008, 123 p., Dissertação (Mestrado em Educação Tecnológica), Programa de Pós-graduação em Educação Tecnológica, Centro Federal de Educação Tecnológica de Minas Gerais, Belo Horizonte, 2008. Disponível em: < http://www.dominiopublico.gov.br/pesquisa/DetalheObraForm.do?select_action= 
\&co_obra=169573> Acesso em 11/05/2016.

NIELSEN. Brasileiros com internet no smartphone já são mais de 70 milhões. Imprensa, Telecom, set. 2015. Disponível em: <http://www.nielsen.com/br/pt/pressroom/2015/Brasileiros-com-internet-no-smartphone-ja-sao-mais-de-70-milhoes.html> Acesso em 21/12/2015.

NÓVOA, Antonio. Concepções e práticas de formação contínua de professores. In: Congresso Nacional de Formação Contínua de Professores: realidades e perspectivas,, 1991, Aveiro. Anais Congresso Nacional de Formação Contínua de Professores Aveiro, Portugal: Universidade de Aveiro, 1991. p. 15-38.

Formação de professores e profissão docente. In: NÓVOA, Antonio. Os professores e sua formação. Lisboa, Portugal: Publicações Dom Quixote/ Instituto de Inovação Educacional, 1995, p. 15- 33

Os professores na virada do milênio: do excesso dos discursos à pobreza das práticas. Educação e Pesquisa, São Paulo. v.25. v.1. p.11-20. jan./jun. 1999. Disponível em: < https://dx.doi.org/10.1590/S1517-97021999000100002> Acesso em: 11/05/2016.

Paulo: Cortez, 2004.

Prefácio (2001). In: JOSSO, M. Experiências de vida e formação. São

OKADA, Alexandra; BUJOKAS, Alexandra. Comunidades abertas de prática e redes sociais de coaprendizagem da UNESCO. In: OKADA, Alexandra (org.). Recursos Educacionais Abertos e Redes Sociais: coaprendizagem e desenvolvimento profissional. Cambridge: The Opens University Press, v.1, 2012. Disponível em <http://openscout.kmi.open.ac.uk/toollibrary/pg/profile/bujokas> Acesso em 07/11/2015.

OLIVEIRA, Marta Kohl. Jovens e Adultos como sujeitos de conhecimento e aprendizagem. In.: RIBEIRO, Vera Masagão (org.). Educação de Jovens e Adultos: novos leitores, novas leituras. Campinas, SP: Mercado de Letras; São Paulo: Ação Educativa, 2001.

OLIVEIRA, Inês. Reflexões acerca da organização curricular e das práticas pedagógicas na EJA. Revista Educar. Curitiba, n. 29, p. 83-100, 2007. Disponível em: <http://www.scielo.br/scielo.php?script=sci_arttext\&pid=S0104-40602007000100007> Acesso em: 12/06/2016.

OLIVEIRA, Cristina Chaves. Qualificação para o trabalho no capitalismo contemporâneo: as tecnologias da informação e comunicação na formação docente inicial na UFMG. 106f. Dissertação (Mestrado em Educação) - Faculdade de Educação. Universidade Federal de Minas Gerais, Belo Horizonte, 2013. Disponível em: <http://www.bibliotecadigital.ufmg.br/dspace/handle/1843/BUBD-9FVG54> Acesso em 12/05/2016.

O’REILLY, Tim. O que é Web 2.0: padrões de design e modelos de negócios para a nova geração se software. Trad. Mirim Medeiros. 2005. Disponível em: $<$ http://pressdelete.files.wordpress.com/2006/12/o-que-e-web-20.pdf> Acesso em 30/12/2013 
PAIVA, Vanilda. Educação popular e educação de adultos. São Paulo: Edições Loyola, 1973.

Anos 90: as novas tarefas da educação de adultos na América Latina. Cadernos de Pesquisa, São Paulo,n. 89, maio 1994, p. 29-38. Disponível em: <http://publicacoes.fcc.org.br/ojs/index.php/cp/article/view/901/908> Acesso em 29/04/2015.

PESCE, Lucila. Formação online de educadores: uma proposta dialógica. In: MATOS, Olívia; PESCE, Lucila. (Orgs.). Educação e cultura midiática. 1a. ed. Salvador: EDUNEB - Editora da Universidade Estadual de Bahia, v. 1, 2012. Disponível em: <http://eduneb.uneb.br/download-2/ p. 121-144> Acesso em: 02/11/2015.

. O Programa Um Computador por Aluno no Estado de São Paulo: confrontos e avanços. In: Anais da XXXVI Reunião Anual da ANPED: Sistema Nacional de Educação e Participação Popular: desafios para as políticas educacionais, 2013, Goiânia: Ed UFG, 2013a. v. 1. p. 1-31. Disponível em: <http://36reuniao.anped.org.br/

pdfs_trabalhos_encomendados/gt16_trabencomendado_lucilapesce.pdf $>$ Acesso em: 29/04/2016.

A potência didática dos recursos educacionais abertos para a docência na contemporaneidade. REVEDUC (UFSCar). v. 07, n. 02, p. 195-210, 2013b. Disponível em: $<$ http://www.reveduc.ufscar.br/index.php/reveduc/article/viewFile/749/270> Acesso em: $11 / 05 / 2016$.

. Políticas de formação inicial de professores, tecnologias e a construção social do tempo. EccoS, Revista Científica. v. 33, n. 01, jan./abril. 2014. p. 157-172. Disponível em: $<$ http://www4.uninove.br/ojs/index.php/eccos/article/viewFile/3598/2721

$>$ Acesso em: 02/11/2015.

PESCE, Lucila; ABREU, Claudia Barcelos de Moura. Pesquisa qualitativa: considerações sobre as bases filosóficas e os princípios norteadores. Revista Educação $e$ Contemporaneidade. v. 22, n. 40, p. 19-30, jul./dez. 2013. Disponível em: <https://docs.google.com/file/d/0Bw5AkbjDMRP7RWQ3d0VjbWJ6LUE/edit> Acesso em $10 / 12 / 2015$.

PINTO, Álvaro Vieira. O Conceito de Tecnologia. Rio de Janeiro: Contraponto, 2005.

PLACCO, Vera Maria Nigro de Souza. Formação em serviço. In: OLIVEIRA, Dalila Andrade; DUARTE, Adriana Maria Cancella; VIEIRA, Lívia Fraga. Dicionário: trabalho, profissão e condição docente. Belo Horizonte: UFMG/Faculdade de Educação, 2010. Disponível em <http://www.trabalhodocente.net.br/index.php> Acesso em 07/07/2015.

PLACIDO, Maria Elze dos Santos. Formação continuada de professores: análise sobre o uso das tecnologias da informação e comunicação - TIC na organização do trabalho pedagógico. São Cristóvão: UFSE, 2011, 123f., Dissertação (Mestrado em Educação) - Núcleo de PósGraduação em Educação, Pró-Reitoria de Pós-Graduação, Universidade Federal do Sergipe, São Cristóvão, 2011. Disponível em: <https://bdtd.ufs.br/handle/tede/1780> Acesso em 12/05/2016. 
PORTO, Tania. As tecnologias de comunicação e informação na escola; relações possíveis...relações construídas. Revista Brasileira de Educação, São Paulo, vol. 11, n. 31, 2006. Disponível em: <http://www.scielo.br/pdf/rbedu/v11n31/a05v11n31.pdf> Acesso em $12 / 05 / 2016$.

PRENSKY, Marc. Digital Natives, Digital Immigrants, Part II: Do They Really Think Differently? MCB University Press, Vol. 9 No. 6. 2001. Disponível em: < http://www.marcprensky.com/writing/Prensky\%20\%20Digital\%20Natives, \%20Digital\%20Im migrants\%20-\%20Part1.pdf> Acesso em 13/07/2015.

Homo sapiens digital: dos imigrantes e nativos digitais à sabedoria digital. In.: APARACI, R. (coord.) Conectados no Ciberespaço, São Paulo: Paulinas, 2012.

PRETTO, Nelson De Luca; ASSIS, Alessandra. Cultura digital e educação: redes já! In.: PRETTO; SILVEIRA. Além das redes de colaboração: internet, diversidade cultural e tecnologias do poder. Salvador: EDUFBA, 2008.

PRETTO, Nelson. Professores autores em rede. In: SANTANA, Bianca; ROSSINI, Carolina; PRETTO, Nelson. (orgs.). Recursos Educacionais Abertos: práticas colaborativas e políticas públicas. Salvador: EDUFBA; São Paulo: Casa da Cultura Digital, 2012. p. 91-108. Disponível em: <http://issuu.com/lucaspretti/docs/livrorea> Acesso em: 08/01/2016.

PROCÓPIO, Elizabete Ramalho. Formação de professores e tecnologias: implicações da educação à distância na prática docente. Juiz de Fora: UFJF, 2011, 139f. Dissertação (Mestrado em Educação) - Programa de Pós-Graduação em Educação, Faculdade de Educação, Universidade Federal de Juiz de Fora, Juiz de Fora, 2011. Disponível em: < http://www.ufjf.br/ppge/files/2011/07/disserta\%C3\%A7\%C3\%A3o-elizabete-ramalhoprocopio.pdf> Acesso em 12/05/2016.

PROINFO APRESENTAÇÃO, 2016. Disponível em: $<$ http://portal.mec.gov.br/index.php?option=com_content $\&$ view=article \&id=244\&Itemid=46 2> Acesso em 12/05/2015.

RIBEIRO, Vera Masagão. A Formação de educadores e a constituição da educação de jovens e adultos como campo pedagógico. Educação e Sociedade, Campinas, ano XX, n. 68, dez., 1999. Disponível em: < http://www.scielo.br/pdf/es/v20n68/a10v2068.pdf> Acesso em 07/01/2016.

Referências internacionais sobre avaliação da educação de jovens e adultos. In: CATELLI JR. et al (Orgs.). A EJA em xeque: desafios das políticas de educação de jovens e adultos no século XXI. São Paulo, Global/Ação Educativa, 2014, p. 17-38.

REGO, Teresa Cristina; MELLO, Guiomar Nano. Formação de professores na América Latina e Caribe: a busca por inovação e eficiência. In: Conferência Regional o Desempenho dos Professores na América Latina e no Caribe: novas perspectivas, Brasília, 2002. Anais... Brasília: $\quad$ MEC, 2002. Disponível em: <http://www.namodemello.com.br/pdf/escritos/oficio/teresaversaoenviada.pdf> Acesso em $13 / 01 / 2016$ 
RESENDE, Maria Aparecida. Os saberes dos professores da Educação de Jovens e Adultos: o percurso de uma professora. Dourados, MS: Editora da UFGD, 2008.

SALESI, Luciana. A influência do uso das tecnologias da informação e comunicação (TIC) na formação de professores. Presidente Prudente: UNOESTE, 2011, 103f., Dissertação (Mestrado em Educação) - Pró-Reitoria de Pesquisa e Pós-Graduação em Educação, Universidade do Oeste Paulista, Presidente Prudente, 2011. Disponível em: $<$ http://apeclx.unoeste.br/tede/tde_busca/arquivo.php?codArquivo=290> Acesso em 11/05/2016.

SANTAELLA, Lucia. Gêneros discursivos híbridos na era da hipermídia. Bakhtiniana, Rev. Estud. Discurso. São Paulo, v. 9, n. 2, p. 206-216, dez. 2014 . Disponível em: <http://www.scielo.br/scielo.php?script=sci_arttext\&pid=S217645732014000200013\&lng=en \&nrm=iso $>$.Acesso em 11/05/2016.

SANTOS, Aparecida de Fátima Tiradentes dos. Teoria do Capital Intelectual e Teoria Do Capital Humano: estado, capital e trabalho na política educacional em dois momentos do processo de acumulação. In: Anais $27^{a}$ reunião da ANPEd. Caxambu, 2004. Disponível em: <http://27reuniao.anped.org.br/gt09/t095.pdf> Aceso em 12/05/2016.

SANTOS, Amaleide. 'Tá vendo aquele edifício moço?' - A especificidade da inclusão digital para trabalhadores da construção civil não alfabetizados. Salvador: UFBA, 2008, 158f., Dissertação (Mestrado em Educação) - Programa de Pós-Graduação em Educação, Faculdade de Educação, Universidade Federal da Bahia, Salvador, 2008. Disponível em: < https://repositorio.ufba.br/ri/handle/ri/11901> Acesso em 12/05/2016.

SANTOS, Ezicléia Tavares. A formação dos professores para o uso das tecnologias digitais nos GTs formação de professores e educação e comunicação da ANPEd - 2000 a 2008 . In.: $32^{a}$ Reunião Anual da ANPEd - Associação Nacional de Pós-Graduação e Pesquisa em Educação, Caxambu, 2009. Disponível em: <http://32reuniao.anped.org.br/arquivos/trabalhos/GT08-5899--Int.pdf> Acesso em: $12 / 05 / 2016$.

SANTOS, Flavia Freitas Fontany dos. Informática e educação: formação de professores e políticas públicas. Rio de Janeiro: UNIRIO, 2011, 80f., Dissertação (Mestrado em Educação) - Programa de Pós-Graduação em Educação, Universidade Federal do Estado do Rio de Janeiro, Rio de Janeiro, 2011. Disponível em: $<$ http://educacao.unirio.br/uploads/Disserta\%C3\%A7\%C3\%B5es/Disserta\%C3\%A7\%C3\%A 3o\%20PPGEdu\%20-\%20Flavia\%20Freitas\%20Fontany\%20dos\%20Santos.pdf> Acesso em: $11 / 05 / 206$

SAVIANI, Demerval. História das idéias pedagógicas no Brasil. 2 ed. Campinas: Autores Associados, 2008.

SCHRAINER, Juliana Cristina. Formação de professores e as possibilidades de utilização das tecnologias da informação e comunicação na aprendizagem. Curitiba: PUC-PR, 2011, 156f., Dissertação (Mestrado em Educação) - Programa de Pós-Graduação em Educação, Centro de Teologia e Ciências Humanas, Pontifícia Universidade Católica do Paraná, Curitiba, 2011. Disponível em: 
$<$ http://www.biblioteca.pucpr.br/tede/tde_busca/arquivo.php?codArquivo=1773> Acesso em $12 / 05 / 2016$.

SECRETARIA DE EDUCAÇÃO DO ESTADO DE SÃO PAULO. Cresce número de matrículas nos Centros de Educação de Jovens e Adultos, 2015. Disponível em <http://www.educacao.sp.gov.br/noticias/cresce-matriculas-nos-ceejas-da-capital-ermsp> Acesso em: 07/01/2016.

SILVA, Helena; JAMBIEIRO, Othon; LIMA, Jussara; BRANDÃO, Marco Antônio. Inclusão Digital e educação para a competência informacional: uma questão de ética e cidadania. Ciência da Informação. Brasília, v. 34, n.1, p. 28-36, jan./abr. 2005. Disponível em: <http://www.scielo.br/pdf/ci/v34n1/a04v34n1> Acesso em 12/06/2016.

SILVA, Everson; ARAÚJO, Clarissa M. Reflexão em Paulo Freire: uma contribuição para a formação continuada de professores. Anais do V Colóquio Internacional Paulo Freire. Recife, p. 1 a $8,2005$.

SILVA, Cleder Tadeu Antão da.; Gariglio, José Ângelo. A formação continuada de professores para uso das Tecnologias da Informação e Comunicação (TIC): o caso do Projeto Escolas em Rede da Rede Estadual de Educação de Minas Gerais. Revista Diálogo Educacional. Curitiba, v. 10, n31, p. 481-503, set./dez. 2010. Disponível em: <www2.pucpr.br/reol/index.php/dialogo?dd99=pdf\&dd1=4289> Acesso em 12/06/2016.

SILVA, Leandro Ferreira. As tecnologias da informação e comunicação na formação inicial de professores de matemática em Recife e região metropolitana. Recife: UFRPE, 2011, 97f., Dissertação (Mestrado em Ensino das Ciências e Matemática) - Programa de Pós-Graduação em Ensino das Ciências e Matemática, Universidade Federal Rural de Pernambuco, Recife, 2011. Disponível em: <http://bdtd.ibict.br/vufind/Record/URPE_ 6bf5293c82ccf4fe50f86cce3ce11cf8> Acesso em: 11/05/2016.

SILVA, Analígia Miranda da. O computador na educação e a formação docente: perspectivas de professores dos anos iniciais do ensino fundamental. In: $36^{a}$ REUNIÃO NACIONAL DA ANPED, 2013, Goiânia - GO. Anais 2013 - Associação Nacional de Pós-Graduação e Pesquisa em Educação, 2013. p. 1-16. Disponível em: < http://36reuniao.anped.org.br/pdfs_trabalhos_aprovados/gt08_trabalhos_pdfs/gt08_2810_text o.pdf> Acesso em 12/05/2016.

SILVEIRA, Sérgio Amadeu. A noção de exclusão digital diante das exigências de uma cibercidadania. In: HTKOWSKI, Tânia Maria (org.). Políticas públicas e inclusão digital. Salvador: $\quad$ EDUFBA, 2008. Disponível em < https://repositorio.ufba.br/ri/bitstream/ufba/202/1/Politicas $\% 20$ publicas $\% 20 \mathrm{e} \% 20$ inclusao $\% 2$ 0digital.pdf $>$ Acesso em 08/09/2016.

Inclusão digital, software livre e globalização contra-hegemônica. In: (Org.) Software livre e inclusão digital. São Paulo, Editora Conrad, 2003.

SOARES, Leôncio. O Educador de Jovens e Adultos e sua formação. Educação em Revista. Belo Horizonte, n. 47, p. 83-100, jun. 2008. Disponível em: <http://dx.doi.org/10.1590/S0102-46982008000100005> Acesso em 12/05/2016. 
As especificidades na formação do educador de jovens e adultos: um estudo sobre propostas de EJA. Educação em Revista. Belo Horizonte, v. 27, n.02, p.303-322, ago., 2011. Disponível em: <http://dx.doi.org/10.1590/S0102-469820110002 00014> Acesso em 11/05/2016.

SORJ, Bernardo; GUEDES, Luís Eduardo. Exclusão Digital: problemas conceituais, evidências empíricas e políticas públicas. Novos Estudos. CEBRAP, São Paulo, v. 72, p. 101117, jul. 2005. Disponível em: <http://dx.doi.org/10.1590/S0101-33002005000200006> Acesso em 11/05/2016.

TAKAHASHI, Tadao. Inclusão social e TICs. Inclusão Social. Brasília, v. 1, n. 1, p. 56-59, out./mar. 2005. Disponível em: < http://revista.ibict.br/inclusao/article/view/1509> Acesso em $11 / 05 / 2016$.

TANURI, Leonor M. História da formação de professores. Revista Brasileira de Educação, Rio de Janeiro, n. 14, p. 61-88, mai. 2000. Disponível em: <http://www.scielo.br/pdf/rbedu/n14/n14a05> Acesso em 12/05/2016.

TARDIF, Maurice. Saberes Docentes e Formação Profissional. 17. Ed. Petrópolis, RJ: Vozes, 2014.

TORRES, Rosa Maria. Resumen ejecutivo. In: TORRES, Rosa Maria. Aprendizaje a lo largo de la vida. Bonn, Educación de Adultos y Desarrollo, Suplemento 60, 2003, p. 17-30. Disponível em: < http://www.sida.se/contentassets/66253bc57a7a4a8fa90351e50ef 66fac/aprendizaje-a-lo-largo-de-toda-la-vida_617.pdf> Acesso em 12/05/2016.

TORRES, Patrícia Lupion; ALCÂNTARA, Paulo; IRALA, Esrom Adriano Freitas. Grupos de consenso: uma proposta de aprendizagem colaborativa para o processo de ensinoaprendizagem. Revista Diálogo Educacional, Curitiba, v. 4, n.13, p.129-145, set./dez. 2004. Disponível em: <www2.pucpr.br/reol/index.php/dialogo?dd99=pdf\&dd1 =76> Acesso em 12/05/2016.

TOZETTO, Jozeli Monteiro. Formação docente, prática pedagógica, tecnologias da informação e comunicação: rupturas e transformações em uma instituição de ensino superior. Curitiba: PUC-PR, 2008, 154f., Dissertação (Mestrado em Educação) - Programa de PósGraduação em Educação, Centro de Teologia e Ciências Humanas, Pontifícia Universidade Católica do Paraná, Curitiba, 2008. Disponível em: < http://www.dominiopublico.gov.br/pesquisa/DetalheObraForm.do?select_action=\&co_obra=1 11193> Acesso em: 11/05/2016.

TRIVIÑOS, Augusto Nibaldo. Método de análise de conteúdo. In: TRIVIÑOS, Augusto Nibaldo. Introdução à pesquisa em ciências sociais: a pesquisa qualitativa em educação. São Paulo: Atlas, 1987. p. 158-166.

TURIANI, José Luis de Melo. Formação continuada de professores e TIC: contribuições do "Curso Mídias na Educação". São Paulo: Mackenzie, 2011, 105f. Dissertação (Mestrado em Educação, Arte e História da Cultura) - Programa de Pós-Graduação em Educação, Arte e História da Cultura, Universidade Presbiteriana Mackenzie, São Paulo, 2011. Disponível em: <http://bdtd.ibict.br/vufind/Record/IPM_557ac2d3c10f909a73a26

367b15c82fd/Details> Acesso em 29/04/2016. 
VALENTE, José Armando. Uso da internet em sala de aula. Educar em Revista. Curitiba, v. 19, p. 131-146, 2002. Disponível em: <http://ojs.c3sl.ufpr.br/ojs2/index.php/ educar/article/view/2086> Acesso em 29/04/2016.

VEIGA, I. P. A. Projeto Político-Pedagógico da escola: uma construção possível. 10 ed. Campinas, SP: Papirus , 2000.

VÓVIO, Claudia Lemos. Formação de educadores de jovens e adultos: a apropriação de saberes e práticas conectadas á docência. In: DALBEN, A. et al (orgs). Convergências e tensões no campo da formação e do trabalho docente: educação de jovens e adultos. Belo Horizonte, Autêntica, 2010.

ZUFFO, Darci. A formação de professores para o uso das tecnologias educacionais: o que apontam as teses e dissertações defendidas no Brasil entre 2003 e 2008. Curitiba: PUC-PR, 2011, 148f. Dissertação (Mestrado em Educação) - Programa de Pós-Graduação em Educação, Centro de Teologia e Ciências Humanas, Pontifícia Universidade Católica do Paraná, Curitiba, 2011. Disponível em: $<$ http://www.biblioteca.pucpr.br/tede/tde_busca/arquivo.php?codArquivo=1890> Acesso em $12 / 05 / 2016$.

\section{DOCUMENTOS:}

BRASIL. Constituição (1988). Constituição: República Federativa do Brasil. Brasília: Senado Federal, 1988.

BRASIL. Ministério da Educação. Instituto Nacional de Estudos e Pesquisas Educacionais. Sinopse Estatística da Educação Básica 2014. Brasília: MEC/INEP, 2014.

CONFERÊNCIA NACIONAL DE EDUCAÇÃO (CONAE). Construindo o sistema Nacional Articulado de Educação: o Plano Nacional de Educação, diretrizes e estratégias. Documento Final. Brasília, DF: 2010.2 Disponível em: $<$ http://conae.mec.gov.br/images/stories/pdf/pdf/documetos/documento_final_sl.pdf > Acesso em $14 / 05 / 2016$.

MAPA DA INCLUSÃO DIGITAL. Coord. NERI, Marcelo. Rio de Janeiro: FGV, CPS, 2012, 190p. Disponível em < http://cps.fgv.br/pesquisas/mapa-da-inclusao-digital> Acesso em $14 / 05 / 2016$

SÃO PAULO. Secretaria Estadual de Educação. Coordenadoria de Estudos e Normas Pedagógicas. Para conhecer um Centro de Educação Supletiva. São Paulo, SE/CENP, 1985, $20 \mathrm{p}$.

Governador do Estado de São Paulo. Lei Complementar $N^{\circ} 836$, de 30 de dezembro de 1997. São Paulo, 1997.

Paulo: SEE, 2011.

Secretaria Estadual de Educação, Resolução $n .^{\circ} 77$ de dezembro de 2011. São 
São Paulo: SEE, 2012

Secretaria Estadual da Educação. Resolução no 08, de 19 de janeiro de 2012.

Secretaria Estadual de Educação, Documento Orientador $n^{\circ} .10$ de 2014, da CGEB (Coordenadoria de Gestão da Educação Básica). São Paulo: SEE, 2014

UNESCO. Padrões de competência em TIC para professores: diretrizes de implementação. Versão 1.0. Brasília: UNESCO, 2009a. Disponível em: <http://unesdoc.unesco.org/images/0015/001562/156209por.pdf> Acesso em 14/05/2016 Padrões de competência em TIC para professores: módulos de padrão de competência. Brasília: UNESCO, 2009b. Disponível em: <http://unesdoc.unesco.org/images/0015/001562/156207por.pdf> Acesso em 28/08/2016.

.Marco de ação de Belém. CONFITEA VI, Belém, Brasil, 2010. Disponível em: $<$ http://www.unesco.org/fileadmin/MULTIMEDIA/INSTITUTES/UIL/confintea/ pdf/working_documents/Belem\%20Framework_Final_ptg.pdf> Acesso em 14/05/2016.

Commonwealth of learning. A basic guide to open educational resources (OER) prepared by Neil Butcher for the Commonwealth of Learning \& UNESCO, 2011. Disponível em: <http://www.unesco.org/new/en/communication-andinformation/ resources/news-and-in-focus-articles/allnews/news/unescocommonwealth_of_learning oer_policy_guidelines_to_be_launched_at_the_unesco_general_conference/\#.VFOjPvnF9qU >. Acesso 20/11/2015 


\section{APÊNDICE A - TERMO DE CONSENTIMENTO LIVRE E ESCLARECIDO - TCLE}

1- Título do projeto: As TDIC na Educação de Jovens e Adultos: um estudo de caso da formação continuada em serviço de professores da EJA para o uso educacional das tecnologias digitais da informação e comunicação

2- Objetivo: O objetivo geral deste estudo é compreender o impacto de um curso de formação continuada em serviço para o uso pedagógico das Tecnologias Digitais da Informação e da Comunicação no repensar da prática de docentes da Educação de Jovens e Adultos.

3- Procedimentos: Serão aplicados questionários aos vinte e sete docentes de um Centro Estadual de Educação de Jovens e Adultos e mais entrevistas semiestruturadas junto a um grupo de seis docentes que serão escolhidos sob critério de seleção, através de um gradiente de adesão (dois professores com efetiva participação nas atividades do curso de formação, dois professores com adesão mediana e dois professores com baixa adesão às atividades propostas). Também fará parte dos procedimentos de pesquisa, a análise documental (Projeto Político Pedagógico das escolas em que os participantes da pesquisa atuam).

4- Desconfortos e riscos esperados: A presença de um pesquisador na escola coletando informações de documentos, bem como realizando entrevistas, poderá trazer algum tipo de desconforto, pelo fato do mesmo também atuar como professor coordenador na mesma instituição. Nesse sentido, se procurará ser discreto e não interferir com o andamento rotineiro das atividades escolares e procurar deixar clara a diferença do papel do pesquisador e do professor coordenador. Além disso, os docentes que aceitarem participar terão de disponibilizar certo tempo para que a entrevista seja realizada; nesse sentido, se procurará ser breve com as entrevistas. Uma vez que o nome da escola, bem como dos participantes e o conteúdo dos questionários e entrevistas serão mantidos em sigilo, o risco de exposição dos mesmos será minimizado.

5- Benefícios para o participante: Espera-se que esta pesquisa possa promover reflexões importantes sobre a relação entre a formação de professores da Educação de Jovens e Adultos, bem como discutir sobre a importância das (re) configurações da prática docente a partir da reflexão crítica sobre o uso pedagógico das Tecnologias Digitais da Informação e da Comunicação.

6- Garantias: Em qualquer etapa do estudo, você terá acesso aos profissionais responsáveis pela pesquisa, para esclarecimento de eventuais dúvidas. O principal investigador é Bruno dos Santos Joaquim, que pode ser encontrado no endereço: Rua do Rosário, $\mathrm{n}^{\circ} 382$ - Macedo Guarulhos - SP - CEP: 07111-080, Telefone: (11) 5576-4848. Se você tiver alguma consideração ou dúvida sobre a ética da pesquisa, entre em contato com o Comitê de Ética em Pesquisa (CEP) - Rua Botucatu, 572 - $1^{\circ}$ andar - cj 14, 5571-1062, FAX: 5539-7162 - Email: cepunifesp@epm.br.

7- É garantida a liberdade da retirada de consentimento a qualquer momento e de deixar de participar do estudo e, as informações obtidas serão analisadas em conjunto com as de outros voluntários, não sendo divulgada a identificação de nenhum participante da pesquisa. 
8- Também é garantido o direito de ser mantido atualizado sobre os resultados parciais das pesquisas, quando em estudos abertos, ou de resultados que sejam do conhecimento dos pesquisadores.

9- Despesas e compensações: Não há despesas pessoais para os participantes da pesquisa em qualquer fase do estudo. Também não há compensação financeira relacionada à sua participação.

10- Compromisso do pesquisador: manter a confidencialidade dos dados e utilizá-los somente para esta pesquisa.

11- Este termo de consentimento livre e esclarecido será assinado em duas vias originais, sendo que uma delas ficará em poder do pesquisador e a outra sob guarda do participante da pesquisa.

12- Todas as páginas deste termo de consentimento livre e esclarecido serão numeradas sequencialmente e assinadas/rubricadas pelos envolvidos.

Acredito ter sido suficientemente informado a respeito das informações que li ou que foram lidas para mim, descrevendo o estudo "As TDIC na Educação de Jovens e Adultos: um estudo de caso da formação continuada em serviço de professores da EJA para o uso educacional das tecnologias digitais da informação e comunicação". Eu discuti com o pesquisador Bruno dos Santos Joaquim sobre a minha decisão em participar deste estudo. Ficaram claros para mim quais são os propósitos do estudo, os procedimentos a serem realizados, seus desconfortos e riscos, as garantias de confidencialidade e de esclarecimentos permanentes. Ficou claro também que minha participação é isenta de despesas. Concordo voluntariamente em participar deste estudo e poderei retirar o meu consentimento a qualquer momento, antes ou durante o mesmo, sem penalidades ou prejuízo ou perda de qualquer benefício que eu possa ter adquirido.

Assinatura do participante da pesquisa/representante legal / data

Assinatura da testemunha / data

Para casos de voluntários menores de 18 anos, analfabetos, semianalfabetos ou portadores de deficiência auditiva ou visual.

Declaro que obtive de forma apropriada e voluntária o Consentimento Livre e Esclarecido deste participante da pesquisa ou representante legal para a participação neste estudo.

Assinatura do responsável pelo estudo / data 


\section{APÊNDICE B - ROTEIRO PARA ENTREVISTA SEMIESTRUTURADA - PROFESSORES}

Pesquisador: Bruno dos Santos Joaquim

Título da Pesquisa: As TDIC na Educação de Jovens e Adultos: um estudo de caso da formação continuada em serviço de professores da EJA para o uso educacional das tecnologias digitais da informação e comunicação

Sujeitos: Seis docentes escolhidos sob o seguinte critério: três professores que executaram oficinas planejadas ao final do curso, fazendo uso crítico das TDIC, sendo um professor de cada área do conhecimento (a- códigos e linguagens, b- ciências humanas e suas tecnologias, c- ciências da natureza e suas tecnologias) e três professores que não executaram as oficinas planejadas, obedecendo também o critério de um por área de conhecimento.

Agradeço a disponibilidade do docente em conceder esta entrevista e contribuir para a presente pesquisa. Os docentes participantes desta pesquisa terão seus nomes mantidos em sigilo, minimizando, desta forma, o risco de exposição dos mesmos.

1. Você faz uso de tecnologias digitais? Quais? Cite exemplo. sim, dê exemplo.

2. Você faz uso de tecnologias digitais nas suas práticas pedagógicas aqui no CEEJA? Se

3. Há dificuldades para a promoção de práticas que fazem uso das TDIC? Se sim, ordene as principais dificuldades?

4. Você é professor de escola regular? Se sim, você integra as TDIC às suas práticas escolares? Você planeja as mesmas atividades na escola regular e no EJA?

5. A partir do que estudamos no curso "Mídias Digitais na Educação de Jovens e Adultos", qual o papel das TDIC na formação para alunos jovens e adultos?

6. Considerando o curso "Mídias Digitais na Educação de Jovens e Adultos", quais são os pontos fortes que devem ser mantidos e que aspectos você identifica como fragilidades, que devem ser alteradas numa segunda oferta da formação?

7. Quais são as necessidades de profissionalização para implementar a integração das TDIC na sua prática professoral?

8. Que noções e temas ficam para você a partir da leitura dialogal dos textos ao longo do curso "Mídias Digitais na Educação de Jovens e Adultos"?

9. Quais noções, temas e práticas estudadas no curso podem acontecer no contexto deste CEEJA?

10. Há algum outro aspecto a respeito do curso que não tenha sido perguntado até agora e que você queira comentar? 


\section{APÊNDICE C - ROTEIRO PARA ENTREVISTA SEMIESTRUTURADA - COORDENADOR}

Título da Pesquisa: As TDIC na Educação de Jovens e Adultos: um estudo de caso da formação continuada em serviço de professores da EJA para o uso educacional das tecnologias digitais da informação e comunicação

Sujeito: Professor Coordenador do CEEJA que participou do processo de planejamento e execução do curso de formação continuada em serviço "Mídias Digitais na Educação de Jovens e Adultos"

Agradeço a disponibilidade em conceder esta entrevista e contribuir para a presente pesquisa. Os docentes participantes desta pesquisa terão seus nomes mantidos em sigilo, minimizando, desta forma, o risco de exposição dos mesmos.

1. Você faz uso de tecnologias digitais? Quais? Cite exemplo.

2. Os professores do CEEJA fazem uso de tecnologias digitais nas suas práticas pedagógicas aqui no CEEJA? Se sim, dê exemplo.

3. Há dificuldades para a promoção de práticas aqui no CEEJA em que os professores façam uso das TDIC? Se sim, ordene as principais dificuldades?

4. A partir do que realizamos com ocurso "Mídias Digitais na Educação de Jovens e Adultos", qual o papel das TDIC na formação para alunos jovens e adultos?

5. Considerando o curso "Mídias Digitais na Educação de Jovens e Adultos", quais são os pontos fortes que devem ser mantidos e que aspectos você identifica como fragilidades, que devem ser alteradas numa segunda oferta da formação?

6. Há algum outro aspecto a respeito do curso que não tenha sido perguntado até agora e que você queira comentar? 


\title{
ANEXO A - PLANO DE CURSO "MídIAS DIGITAIS NA EDUCAÇÃo DE JOVENS E ADULTOS
}

\author{
SECRETARIA DE EDUCAÇÃO DO ESTADO DE SÃO PAULO \\ DIRETORIA DE ENSINO REGIÃO DE SÃO VICENTE \\ CENTRO ESTADUAL DE EDUCAÇÃO DE JOVENS E ADULTOS (CEEJA)
}

\section{PROJETO DE FORMAÇÃO CONTINUADA EM SERVIÇO \\ "Mídias Digitais na Educação de Jovens e Adultos"}

\section{Responsável:}

Prof. Coordenador Bruno Joaquim - Mestrando do Programa de Pós-Graduação em Educação da Universidade Federal de São Paulo (UNIFESP).

Contato: brunosjoaquim@hotmail.com

Carga Horária: 15 horas

\section{Período:}

10,17 e 24 de abril e 8 e 15 de maio - 13 h10 às 15 h10 (aulas de ATPC)

\section{Justificativa:}

O curso de formação continuada em serviço promovida pela equipe gestora do "CEEJA

" tem por objetivo central mobilizar o corpo docente da escola para o uso pedagógico das Tecnologias Digitais da Informação e da Comunicação (TDIC), a partir de uma visão crítica dessas ferramentas e tendo a educação de pessoas adultas como foco central. $\mathrm{O}$ curso se articula com a proposta pedagógica da escola e com a necessária mudança na relação entre a escola e o conhecimento, no contexto da cibercultura.

$\mathrm{O}$ uso das aulas de trabalho pedagógico coletivo (ATPC) se justifica pela importância deste espaço para a formação continuada de professores. Nesta unidade de ensino, as possibilidades de formação das ATPC se potencializam pelo fato do corpo docente se reunir por completo neste encontro semanal. Em avaliação realizada ao final do ano letivo de 2014, os professores apontaram a temática do uso pedagógico das TDIC como um dos três temas mais relevantes para formação continuada em ATPC.

Este projeto de formação compõe parte da pesquisa referente à dissertação do mestrando Bruno Joaquim, do Programa de Pós-Graduação em Educação da Universidade Federal de São Paulo.

\section{Objetivos:}

- Mobilizar o corpo docente para a reflexão acerca das Mídias Digitais e suas implicações para a relação entre a escola e o conhecimento. 
- Discutir as implicações das mídias digitas a partir de uma postura crítica de rejeição à perspectiva instrumental;

- Refletir sobre as possibilidades de empoderamento através da inclusão digital de pessoas adultas reinseridas no ambiente escolar através da EJA;

- Elaborar projetos de oficinas e produção de material didático a partir do uso das TDIC, com a intenção de promover aproximação reflexiva entre os alunos e as mídias digitais.

\section{Conteúdo Programático:}

1. Cibercultura e Mídias Digitais

2. Empoderamento Freireano e Inclusão Digital

3. Recursos Educacionais Abertos e Aprendizagem Colaborativa

4. Redes Sociais e Inteligência Coletiva

\section{Metodologia:}

- Grupos de discussão

- Leitura e discussão dos textos previamente indicados

- Vídeos previamente selecionados

- Elaboração de projetos de oficinas com o uso das TDIC

\section{Recursos:}

- Bibliografia básica

- Projetos de Multimídia

- Laboratório com acesso à internet

\section{Avaliação:}

Leitura dos textos e participação nas discussões e na construção de projetos de oficinas.

\section{Bibliografia:}

Básica:

LÈVY, Pierre. Cibercultura Trad. C. I. Costa. São Paulo: Ed. 34, 1999. (Cap. 10 - A nova relação com o saber).

BONILLA, Maria Helena. Políticas públicas para inclusão digital nas escolas. Motrivivência, ano XXII, n. 34, p.

40-60, jun. 2010. Disponível em: http://www.periodicos.ufsc.br/index.php/motrivivencia/article/view/17135

PRETTO, Nelson. Professores autores em rede. In: SANTANA, B.; ROSSINI, C.; PRETTO, Nelson (orgs.). RecursosEducacionais Abertos: práticas colaborativas e políticas públicas. Salvador: EDUFBA; São Paulo: Casa da Cultura Digital, 2012. Disponível em: http://www.livrorea.net.br/livro/home.html p. 91-108

MATTAR, João. Web 2.0 e Redes Sociais na Educação. São Paulo: Artesanato Educacional, 2013. (Cap. 01 e 03).

BRITO, Bianca Maria Santana. Novas tecnologias na educação de jovens e adultos: quem usa a favor de quem e para quê? 
Disponível em: http://alb.com.br/arquivomorto/edicoes_anteriores/anais17/txtcompletos/sem02/COLE_1275.pdf

Complementar:

DIAS, Lia Ribeiro. Inclusão digital como fator de inclusão social. In: PRETO, Nelson; BONILLA, Maria Helena

(orgs.). Inclusão digital: polêmica contemporânea. Salvador: EDUFBA, 2011. p. 61-90.

Disponível em: https://repositorio.ufba.br/ri/bitstream/ri/4859/1/repositorio-Inclusao\%20digitalpolemicafinal.pdf

FREIRE, P. \& SHOR, I. (1987). Medo e ousadia: o cotidiano do professor. $7^{\text {a }}$. ed. São Paulo: Paz e Terra, 1997.

PEÑA, Maria de los Dolores et al. Recursos educacionais abertos: nova cultura de produção e socialização de saberes no ciberespaço. In: OKADA, Alexandra. (Org.). Recursos Educacionais Abertos e Redes Sociais coaprendizagem e desenvolvimento profissional. Cambridge: The Open University Press, 2012, v. 1, pp. 1-27.

Disponível em: http://oer.kmi.open.ac.uk/?page_id=2115

VIEIRA, Iúta. Leitura na Internet: mudanças no perfil do leitor e desafios escolares. In: ARAÚJO, Júlio César. (org.). Internet \& ensino: novos gêneros, outros desafios. Rio de Janeiro: Lucerna, 2007. pp. 248-267.

PESCE, Lucila. A potencialidade das interfaces interativas para a aprendizagem colaborativa. Revista Diálogos \& Ciência (FTC), v. 1, p. 119/8-135, 2010.

Disponível

em:

http://dialogos.ftc.br/index.php?option=com_content\&task=view\&id=227\&Itemid=1

\section{Videografia:}

Básica:

O que é cibercultura? (EducaRede Brasil) - http://youtu.be/hCFXsKeIs0

Cibercultura - Pierre Levy - http://youtu.be/NVW5L9szFr0

Inclusão Digital (animação) - http://youtu.be/w0-2GixZk3Q

Inclusão Digital (Jornal Hoje) - http://youtu.be/Gr7TGb3igzA

Recursos Educacionais Abertos - Bianca Santana - http://youtu.be/1wByUzxhaDY

Web 2.0 (not in words) - http://youtu.be/Bc0oDIEbYFc

Redes Sociais em Educação - http://youtu.be/6ZqoxzkjQlw

Complementar:

Pierre Lévy - As formas de Saber

http://youtu.be/i5Ko5gGPF4w

http://youtu.be/QIo2Q1QMN5k

http://youtu.be/cd0QbWBJwHU

http://youtu.be/9rxl75PcpaA

Conceito de Inclusão Digital - http://youtu.be/JK7pXK0uvbA 


\begin{tabular}{|c|c|c|}
\hline $\begin{array}{l}\text { O po } \\
\text { http://y } \\
\text { Tecnol } \\
\text { do k } \\
\text { O que }\end{array}$ & $\begin{array}{l}\text { er da tecnologia } n \\
\text { dutu.be/b5TdZ_ox99A } \\
\text { gias na sala de aula: } \mathrm{R} \\
\text { Inteligência Coletiva? }\end{array}$ & $\begin{array}{l}\text { educação: João Gabriel Alkmim at TEDxLacador - } \\
\text { bem Saldanha at TEDxUnisinos 2013- http://youtu.be/OdcSxb- } \\
\text { osdacomuncacao) - http://youtu.be/SaCJerTn_Eg }\end{array}$ \\
\hline & & Cronograma \\
\hline $10 / 04$ & $\begin{array}{ll}\text { Cibercultura } & \mathrm{e} \\
\text { Mídias Digitais } & \end{array}$ & $\begin{array}{l}\text { Texto: } \\
\text { LĖVY, Pierre. Cibercultura Trad. C. I. Costa. São Paulo: Ed. } \\
\text { 34, 1999. (Cap. } 10 \text { - A nova relação com o saber). } \\
\text { Vídeos: } \\
\text { O que é cibercultura? (EducaRede Brasil) - } \\
\underline{\text { http://youtu.be/hCFXsKeIs0w }} \\
\text { Cibercultura - Pierre Levy - } \underline{\text { http://youtu.be/NVW5L9szFr0 }}\end{array}$ \\
\hline $17 / 04$ & $\begin{array}{l}\text { Empoderamento } \\
\text { Freireano e Inclusão } \\
\text { Digital }\end{array}$ & 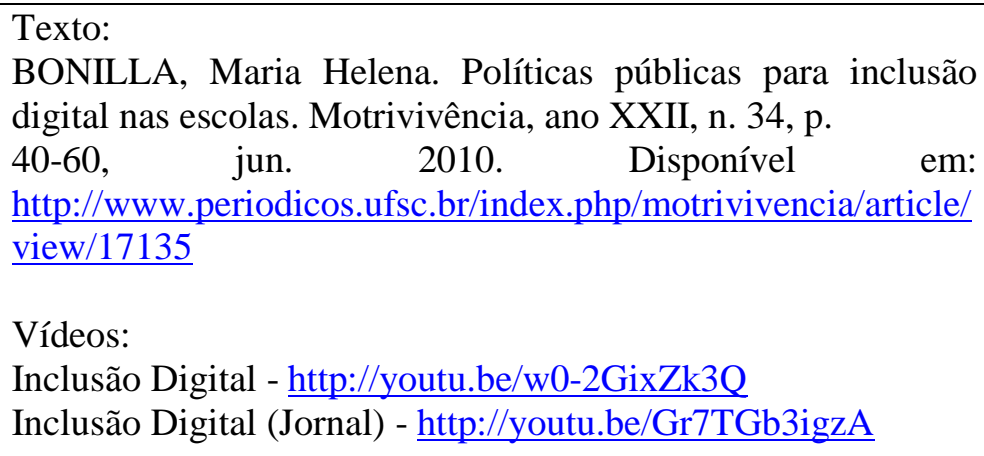 \\
\hline $24 / 04$ & $\begin{array}{l}\text { Recursos } \\
\text { Educacionais } \\
\text { Abertos } \\
\text { Aprendizagem } \\
\text { Colaborativa }\end{array}$ & 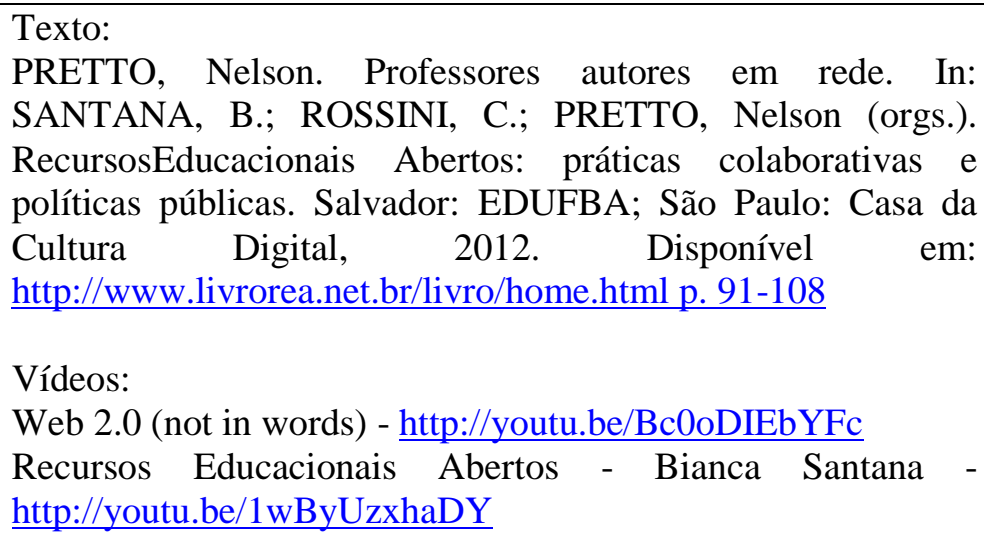 \\
\hline $08 / 05$ & $\begin{array}{l}\text { Redes Sociais e } \\
\text { Inteligência Coletiva }\end{array}$ & $\begin{array}{l}\text { Texto: } \\
\text { MATTAR, João. Web } 2.0 \text { e Redes Sociais na Educação. São } \\
\text { Paulo: Artesanato Educacional, 2013. (Cap. } 01 \text { e 03). } \\
\text { Vídeos: } \\
\text { Redes Sociais em Educação - http://youtu.be/6ZqoxzkjQlw }\end{array}$ \\
\hline $15 / 05$ & $\begin{array}{l}\text { Elaboração de } \\
\text { projetos de oficinas }\end{array}$ & $\begin{array}{l}\text { Texto: } \\
\text { BRITO, Bianca Maria Santana. Novas tecnologias na } \\
\text { educação de jovens e adultos: quem usa a favor de quem e } \\
\text { para quê? }\end{array}$ \\
\hline
\end{tabular}




\begin{tabular}{|l|l|l|}
\hline & $\begin{array}{l}\text { Disponível em: } \\
\text { morto/edicoes_anteriores/anais17/txtcompletos/sem02/COLE_-br/arquivo- } \\
\text { 1275.pdf }\end{array}$ \\
\hline
\end{tabular}




\section{ANEXO B - ASSENTIMENTO DA ESCOLA PARA REALIZAÇÃO DA PESQUISA}

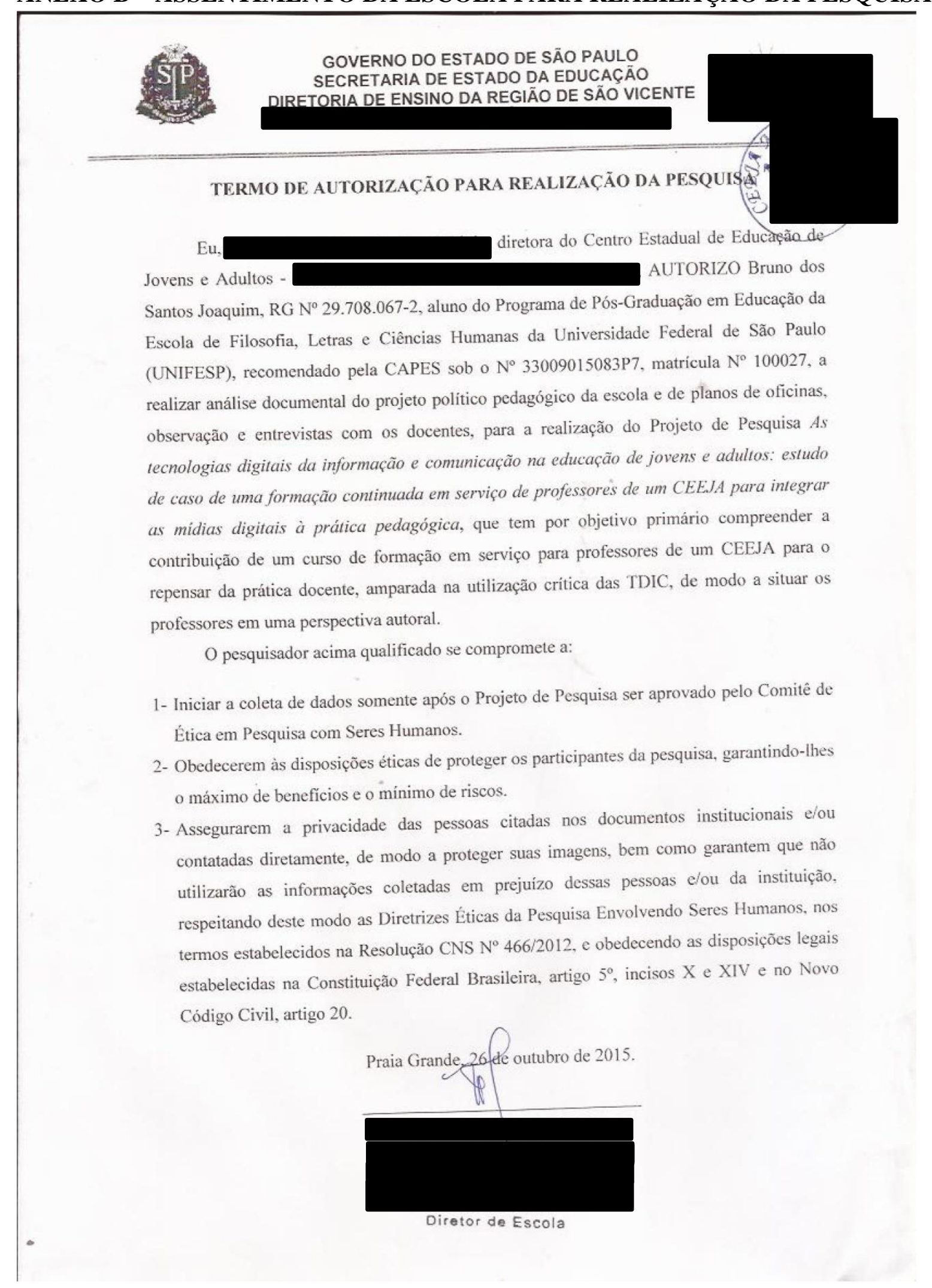




\section{ANEXO C - ENTREVISTA - PROF. RITA DE CÁSSIA}

É oportuno observar que a transcrição, na íntegra, dos depoimentos reproduz fielmente a coloquialidade característica da linguagem oral.

Entrevistada: Prof. ${ }^{a}$ Rita de Cássia Lima Alves (nome fantasia)

Entrevistador: Bruno dos Santos Joaquim

Transcrição: Bruno dos Santos Joaquim

Data: 28 de junho de 2016

Pesquisador: Agradeço a disponibilidade da professora em conceder esta entrevista e contribuir para a presente pesquisa. Os docentes participantes desta pesquisa terão seus nomes mantidos em sigilo, minimizando, desta forma, o risco de exposição dos mesmos. Bom, para começar, pergunto se você faz uso das tecnologias digitais?

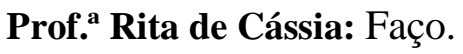

Pesquisador: Quais?

Prof. ${ }^{a}$ Rita de Cássia: Você quer saber eu, em particular, ou eu como os alunos?

Pesquisador: Os dois aspectos: pedagógico e pessoal.

Prof. ${ }^{a}$ Rita de Cássia: Em particular sempre, né? Em pesquisas, desenvolvimento de projetos, também para execução de provas, elaboração de provas. E com os alunos a gente, durante a, eu acho que durante esses ATPC, surgiu na nossa área a necessidade de a gente encaixar isso nas nossas avaliações periódicas. Então, até incentivado por isso, até a gente tem o uso do vídeo da internet como uma das nossas avaliações, como fontes de pesquisa. A gente, por conta dessas oficinas, dessas ATPC, nós fizemos um blog, foi a partir daí. A gente já vinha pensando no blog, porém eu acho que esse curso deu pra gente o start que a gente precisava para isso. Então a gente alimenta esse blog, que é um canal de comunicação com os alunos, um pouco menos acessado ou trabalhado do que eu gostaria. Mas acho que foi um fator preponderante, assim, pra gente utilizar. E a gente continua repetindo a oficina de tabela periódica, interagindo com os alunos com o uso de tecnologias de informação.

Pesquisador: E na sua vida pessoal?

Prof. ${ }^{\text {a }}$ Rita de Cássia: Ah, praticamente eu uso o smartphone, também como fonte de pesquisa, na elaboração de trabalhos pessoais. Tenho pesquisado muito a questão de comportamento, por conta do meu filho. E para lazer também.

Pesquisador: E redes sociais?

Prof. ${ }^{a}$ Rita de Cássia: Redes sociais para lazer mesmo.

Pesquisador: Agora, pensando nas questões pedagógicas, você faz uso de tecnologias digitais nas suas práticas pedagógicas aqui no CEEJA? Você já adiantou algumas coisas, mas fala um pouco mais.

Prof. a Rita de Cássia: A gente utiliza o computador como meio de vídeo, disponibilizado pelo próprio programa "EJA no mundo do trabalho", como um item de estudo, ele é obrigatório em uma prova e ele é facultativo nas outras, mas a gente incentiva bem o uso disso. Alguns 
trabalhos que são complementares do material que a gente está utilizando, a gente também utiliza como pesquisa da internet. E especificamente da internet que é para que ele tenha esse contato com essa sala [entrevista realizada na sala de leitura/informática], que acho que era o ponto principal, a utilização da sala de informática e da sala de leitura. E eu acho que essa prática de ter vários trabalhos fez com que eles utilizassem mais aqui até para outras coisas.

Pesquisador: Você acha que há dificuldades para a promoção de práticas que fazem uso das TDIC?

Prof. ${ }^{a}$ Rita de Cássia: Aqui não. Aqui não. Mas, assim, eu comecei a dar aula em 1993. Quando surgiram as primeiras salas de informática a gente não tinha acesso à internet. A gente tinha programas que vinham, que eram disponibilizados pelo Estado, e eu sempre utilizei o "fracionando", o "como as coisas funcionam". Não sei se você teve acesso a isso, porque você não era nem nascido. [risos] Então eu sempre fui uma professora, até em Guarulhos, quando eu trabalhava lá em Guarulhos, no Francisco Antunes, eu era uma das únicas professoras que levava eles para utilizar esses softwares. Tem uma série de outros softwares. E aí, na escola aqui, já em Praia Grande, também utilizei um software de química, que é um laboratório virtual, mas a gente sempre encontrou muitos entraves. Quando eu comecei aqui eu tinha uma diretora que ela achava que o material, o equipamento quebrava porque ele estava sendo usado. Então, isso nos deu muita liberdade para trabalhar. Mas encontrei diretores também que pensavam ao contrário, que a sala não podia ser utilizada, se não ia quebrar. Porque a gente sabe que a manutenção é difícil, manter os computadores funcionando é complicado. E eu não vejo muito isso aqui no CEEJA. Então, a dificuldade que eu sinto, que nós sentimos, por exemplo, foi até uma reivindicação, porque no primeiro mês aqui no CEEJA teve uma explosão de oficinas. Então, como não tinha espaço, usavam muito essa sala. A gente começou a interferir nisso, porque ela é um instrumento de estudo para a avaliação. Então a gente pediu para que essa sala não fosse utilizada tanto. Esse foi um dos entraves no começo do ano. O aluno ficava brecado.

Pesquisador: No começo desse ano?

Prof. a Rita de Cássia: Desse ano. Em fevereiro, março, se não me engano. Foi uma explosão que eles não tinham espaço aqui. Então nós interferimos. Esse foi, acho, o único entrave que a gente sentiu, porque o aluno tinha que ficar esperando para a sala, para poder assistir a um vídeo que era obrigatório e tal. Mas, assim, não sinto que eles têm dificuldade. A dificuldade que a gente tem é que os vídeos não passam no smartphone. Eles não têm, não conseguem ter acesso aos vídeos do programa pelo celular, então quem não tem internet em casa, tem que ser aqui. Mas fora isso, acho que a utilização da sala, por exemplo, depois desse período em que deram uma maneirada no uso desta sala. Eu não vejo problema nenhum.

Pesquisador: O fato da sala de informática dividir espaço com a sala de leitura, é um problema?

Prof. a Rita de Cássia: Não. Não achei. A princípio, eu pensava que sim, mas, por outro lado, o meu trabalho, que a gente conversou bastante, de utilização da sala de leitura, ficou meio obsoleto. Você lembra que a diretora pediu para que a gente criasse um projeto que utilizasse a sala de leitura e tal? Então, ficou meio obsoleto, porque eles usam muito aqui, agora. Então, é um espaço compartilhado que eles acabam usando muito, mas não para leitura, diga-se de passagem, mais por conta da informática mesmo. 
Pesquisador: Você é professor de escola regular?

Prof. ${ }^{a}$ Rita de Cássia: Sim, escola privada.

Pesquisador: Lá você também integra as TDIC às suas práticas escolares?

Prof. a Rita de Cássia: Difícil.

Pesquisador: Por que? Quando você consegue planejar e executar atividades na escola regular você procura trazê-la da mesma forma para a EJA? Ou o contrário, você leva daqui para lá?

Prof. a Rita de Cássia: Acho que é um misto. É um misto, principalmente a prática. Tem prática que eu faço lá porque lá eu dou aula de ciências, aqui de química. Algumas práticas, algumas aulas práticas que eu fiz lá com eles eu trouxe para cá e algumas daqui pra lá. Lá é uma escola que não tem computador, não tem sala de informática. A justificativa deles lá é que os computadores da escola vão estar sempre obsoletos em relação aos alunos. A gente tem computadores que a gente pode utilizar, mas é sempre muito difícil esse acesso. Então a gente acaba tendo uma aula assim, a aula lá é mais tradicional do que a do Estado, com certeza.

Pesquisador: Bom. A partir do que a gente estudou no curso "Mídias Digitais na Educação de Jovens e Adultos", qual o papel das TDIC na formação para alunos jovens e adultos?

Prof. ${ }^{a}$ Rita de Cássia: É abrangente isso, né? Eu acho que primeiro é se conectar com o mundo, né? A gente tinha uma visão muito pequena, eu acho, de mundo. E entender que você tem um leque de opções, que você pode buscar conhecimento em qualquer parte do mundo, eu acho que isso é muito importante. Você pensar que você está aqui e você pode de repente consultar uma biblioteca do Cazaquistão. Eu acho que a gente está muito longe dos alunos terem essa curiosidade. Mas eu acho que a prática, utilizar na prática, utilizar várias vezes, ter que utilizar, acaba despertando para uma outra coisa. Porque a ideia é, quando você faz uma pesquisa sobre, sei lá, proteínas, de repente ali ele tenha uma outra dúvida, e isso puxe outra dúvida, e mais outra dúvida. E eu acho que quem não está inserido está fora do mundo, está fora do mercado, principalmente do mercado de trabalho. Eu acho que é um ponto chave para nossos alunos: vir aqui para conseguir uma melhor colocação de mercado. E sem falar de alunos com limitações, né? Alunos com deficiência visual, deficiência auditiva. Acho que as tecnologias são importantes para inserir eles em um contexto que, até então, não seria possível.

Pesquisador: E você acha que se não fosse a EJA, pensando a EJA de modo geral, os alunos não teriam essa oportunidade de inclusão no mundo digital?

Prof. ${ }^{a}$ Rita de Cássia: Não. E essa nossa modalidade aqui, ainda é muito mais importante. Porque ela molda, ela se molda na disponibilidade do aluno. E eu acho que isso é importante. E a gente percebe que nós temos alunos com idade mais avançada, que sempre mostraram muita resistência à tecnologia. E ser obrigado, digamos assim, entre aspas, ser obrigado a pesquisar, a utilizar o computador, pode ter aberto muitas portas, muitas janelas aí, para entender um pouco como é que está o mundo agora. Porque a gente pensa assim, o cara que está desempregado com cinquenta, sessenta anos, que não tem o domínio da tecnologia, ele já está fora pela idade, ele está fora pelo desconhecimento. Eu acho que a escola tem esse papel. Quando a gente insere essa obrigatoriedade. Ah, eu nunca mexi no computador. Bom, então vamos lá, você vai ter que se virar, vai ter que mexer, vai ter que se virar, porque você vai precisar. Eu acho que esse start, eu acho que é importante. 
Pesquisador: Considerando o curso "Mídias Digitais na Educação de Jovens e Adultos", quais são os pontos fortes que devem ser mantidos e que aspectos você identifica como fragilidades, que devem ser alteradas numa segunda oferta da formação?

Prof. ${ }^{a}$ Rita de Cássia: Eu acho que o ponto forte é o instigar. Eu me senti instigada. O [nome suprimido] se sentiu instigado, que é meu companheiro de área. A gente saiu daqui falando sobre o curso. $\mathrm{O}$ ponto fraco eu acho que é ser obrigatório para todo mundo. Eu acho que tem que ter interesse, né? Então, a partir do momento em que eu acho muito válido, achei pouco, achei que tinha que ter mais, mas o cara tem que estar ali porque quer. Entendeu? Tem que ser por adesão. Porque aí você consegue, de repente, cobrar, você pode ter um feedback mais significativo, eu acho. Me incomoda um pouco esse "ai que saco, eu estou aqui". Mas, assim, o ser instigante e partir para discussão desse uso, dos entraves, dos porquês, porque o professor é tão resistente, isso eu achei bastante importante. Fez com que a gente falasse: "não, espera lá, a gente tem que se sacudir, porque nós estamos parados aqui". Para mim serviu como uma corda, assim.

Pesquisador: Você avalia que houve baixa adesão dos colegas professores?

Prof. ${ }^{a}$ Rita de Cássia: Baixa.

Pesquisador: E por que você acha que isso aconteceu?

Prof. ${ }^{a}$ Rita de Cássia: Porque existe um certo comodismo de estar aqui, de se achar, prepotente não é bem a palavra, mas achar que não pode, que não precisa melhorar, entendeu? Achar que o que faz é o bastante. Então, às vezes eu até comento com o [nome suprimido] que quando a gente acha que o que faz é o bastante, a gente podia aposentar. Eu nunca acho que faço o bastante. Então, eu quero sempre fazer mais, mais para os meus alunos, pelas dificuldades que eles têm. Eu quero tentar ajuda-los sempre da melhor maneira. E eu não vejo isso em todo mundo. Venho, cumpro minha obrigação, saio daqui, acabou, se pede para eu ficar mais uma hora, nem por decreto. Então, eu penso que, sabe aquela história do sapo que colocaram na água? Conhece?

Pesquisador: Acho que conheço.

Prof.a Rita de Cássia: Você coloca o sapo na água fria e vai esquentando, ele não sai de lá. Acho que é bem por aí, acomodado.

Pesquisador: Quais são as necessidades de profissionalização para implementar a integração das TDIC na sua prática professoral? O que falta?

Prof. a Rita de Cássia: Vontade. Falta vontade. Porque, assim, eu fico pensando que tudo aquilo que eu sei de Word, de Excel, de Paint, de outros mecanismos, eu aprendi sozinho, eu não fiz curso nenhum. Porque eu queria saber, porque eu queria aprender, eu tinha vontade. Então, eu acho que falta vontade. A gente está falando exclusivamente de tecnologia, mas é vontade. $\mathrm{O}$ professor perdeu a vontade, né? A vontade de ensinar, a vontade de fazer diferença. Então, eu acho que, mas eu acho que água mole em pedra dura, né?

Pesquisador: O que poderia estimular essa vontade, na sua visão?

Prof. ${ }^{a}$ Rita de Cássia: Formação, com certeza. Com certeza. Porque se as cinco ATPC instigaram dois, dez ATPC podem instigar seis. Eu vi também o pessoal de biologia instigado, eles também utilizaram os recursos, né? A partir daí, eles já tinham até uma oficina sobre isso, que é bastante interessante, de como estudar e tal. Eu acho que a avaliação aqui devia ser assim: você teve essa formação, e o que você fez a respeito? Porque uma das avaliações do 
ano passado foi comissões. Ah, você participou das comissões, então você foi bem avaliado, você não participou então não foi. Meu, no começo do ano todo mundo queria fazer parte de todas as comissões. E aí, o que acontece? O cara está na comissão não é porque ele não tem vontade de ajudar, é porque ele vai ser avaliado no final do ano. Entendeu? Agora, se a coisa é por adesão, "olha eu quero aprender". Como foi a história da vídeo-aula. A vídeo-aula o Cleber já fez, logo de cara, ele achou bacana, não sei o quê. Mas aí, é assim: ele é sempre o caxias, sempre o que faz primeiro, que sempre está na frente. Isso aí acaba sendo desestimulante, porque você não é estimulado pelos colegas. Parece uma competição. Mas eu acho que a formação deveria continuar. Ela deve continuar. E a exigência de utilizar as tecnologias deve ser importante. Deve ser exigida pelo coordenador, pelo gestor. Porque se você não faz uso disso, você está fora, Bruno, fora do que é agora e do que vai ser no futuro. Então, eu acho que tinha que continuar sim.

Pesquisador: Bom, estamos acabando. Que noções e temas ficam para você a partir da leitura dialogal dos textos ao longo do curso "Mídias Digitais na Educação de Jovens e Adultos"?

Prof. ${ }^{a}$ Rita de Cássia: Olha, eu me lembro muito de uma discussão que a gente teve, da questão do, a gente estava falando sobre a questão das idades e sobre os modos como aprendem as tecnologias e da resistência. Depois dessa discussão, a gente levou muito essa utilização, de como a gente faria aquela oficina para quem nunca tinha acessado. A gente fez a oficina, e tinha aluno que não tinha e-mail. E para ele interagir na nossa oficina, no nosso blog, ele tinha que ter um e-mail para poder responder. Então, eu me lembro muito mais dessa situação. Acho que só. Não sei. Eu só lembro que a gente saia de cada ATPC pensando: “a gente tem que, a gente tem que, a gente tem que, a gente tem que fazer alguma coisa que coloque, que insira essas tecnologias nas nossas avaliações".

Pesquisador: Quais noções, temas e práticas estudadas no curso podem acontecer no contexto do CEEJA?

Prof. ${ }^{a}$ Rita de Cássia: Acho que todos, né? Não sei especificar, mas o que nós mudamos em nossas oficinas e nossas avaliações também. Depende de tudo o que falei, mas tudo pode acontecer. Tem que ter vontade. Insistir. Experimentar.

Pesquisador: Para encerrar. Há algum outro aspecto a respeito do curso que não tenha sido perguntado até agora e que você queira comentar?

Prof. ${ }^{a}$ Rita de Cássia: Eu sinto falta um pouco da clareza de objetivo nas ATPC, quando não estão organizadas como no curso que você fez. É importante você saber o porquê de você estar discutindo aquilo. Entendeu? Essa clareza de objetivo, assim, eu acho bastante importante. Eu acho que foi bacana. A gente aprendeu bastante.

Pesquisador: Valeria a pena fazer outro?

Prof.a Rita de Cássia: Ah, vale. Eu sou muito a favor da formação em horário de trabalho. Quando eu era coordenadora, eu fiz o Ensino Médio em Rede, o número um e o número dois. Eu achava, assim, muito pertinente as discussões. Embora ele fosse por adesão, você poderia fazer se quisesse ou não, eu tive muitos problemas também. O cara que estava ali, mas ele não queria fazer as tarefas, não queria entregar as coisas. Não é fácil, eu sei que não é fácil. Mas eu acho que tinha que continuar sim, discutir sim. Da mesma forma que a gente tem que discutir avaliação, que faz tempo que não se discute aqui, a gente tem que discutir a inclusão. A gente acaba discutindo quando os problemas surgem, assim, a gente acaba sendo pego de 
surpresa. Acho que a gente também tinha que fazer umas discussões de tolerância. Acho que utilizar mais aqui com os professores, coisas mais dinâmicas, mas sempre por adesão. A gente percebe que aqui, ou em qualquer outra escola, quando o cara diz "eu quero fazer aquilo", as coisas fluem melhor.

Pesquisador: Muito obrigado, professora.

Prof. ${ }^{a}$ Rita de Cássia: De nada, Bruno. Espero ter ajudado sua pesquisa. 


\section{ANEXO D - ENTREVISTA - PROF.a CLÁUDIA}

É oportuno observar que a transcrição, na íntegra, dos depoimentos reproduz fielmente a coloquialidade característica da linguagem oral.

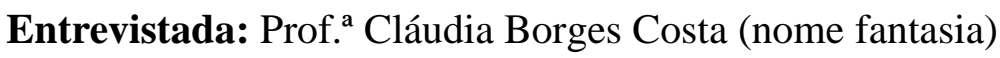

Entrevistador: Bruno dos Santos Joaquim

Transcrição: Bruno dos Santos Joaquim

Data: 23 de junho de 2016

Pesquisador: Agradeço a disponibilidade da docente em conceder esta entrevista e contribuir para a presente pesquisa. Os docentes participantes desta pesquisa terão seus nomes mantidos em sigilo, minimizando, desta forma, o risco de exposição dos mesmos.

$\mathrm{Eu}$ vou seguir um roteiro de entrevista. Você deve ficar a vontade para responder o que pensar, livremente, e, ao longo das suas falas, vou fazendo algumas intervenções para ressaltar os pontos mais importantes da pesquisa.

Prof. ${ }^{\text {a }}$ Cláudia: Tudo bem.

Pesquisador: Primeiramente, você faz uso de tecnologias digitais?

Prof. ${ }^{a}$ Cláudia: Sim

Pesquisador: Quais?

Prof. ${ }^{a}$ Cláudia: As redes sociais, para trabelho e pesquisa. E também para comunicação.

Pesquisador: Mas seu uso ocorre na vida pessoal e também.

Prof. ${ }^{a}$ Cláudia: Sim, também no trabalho.

Pesquisador: E você faz uso das tecnologias digitais nas suas práticas pedagógicas aqui no CEEJA?

Prof. ${ }^{\text {a }}$ Cláudia: Sim.

Pesquisador: Dá um exemplo para mim.

Prof. ${ }^{a}$ Cláudia: Na oficina que a gente faz, de jogos geográficos. E também na comunicação com eles, né? A gente usa Facebook.

Pesquisador: Você usa o Facebook para se comunicar com os alunos?

Prof. ${ }^{a}$ Cláudia: Isso para me comunicar com eles.

Pesquisador: Legal. E mais algum outro exemplo?

Prof. Cláudia: Vídeo seria?

Pesquisador: Sim.

Prof. ${ }^{a}$ Cláudia: Tem os vídeos que a gente usa, os documentários que a gente passa para eles também.

Pesquisador: Nas oficinas?

Prof. ${ }^{a}$ Cláudia: Isso, nas oficinas. E eles assistem também naquela pesquisa que a gente fez lá na sala de informática. Eu faço um roteiro e os alunos fazem uma pesquisa sobre o tema indicado.

Pesquisador: E como você sente a recepção deles em relação à essas práticas? 
Prof. ${ }^{a}$ Cláudia: Os mais velhos, com idade um pouco mais avançada, eles tem receio. É o medo da prática, né? Eles ainda não sabem mexer, às vezes não tem acesso. Então você vai e dá aquele auxílio, né? Os novos não. Entrou, é pá-pum. Porque eles têm mais acesso e mais facilidade, né? Então eles já conhecem, já sabem mexer. Então eles vão sozinhos. Agora os de mais idade, assim, é mais difícil.

Pesquisador: Você acha que há dificuldades para a promoção de práticas que fazem uso das TDIC aqui no CEEJA?

Prof. ${ }^{a}$ Cláudia: Não. Pelo contrário, dentro da escola, eu acho que poderia até ter mais, assim, da nossa parte, né? $\mathrm{Eu}$ acho que poderia ter mais atividades, entre elas, as interdisciplinares. Deveriam ser desenvolvidas mais.

Pesquisador: Você acha que a escola garante estrutura e autonomia para isso?

Prof. ${ }^{a}$ Cláudia: Estrutura que você diz é técnica ou o apoio?

Pesquisador: Ambas.

Prof. ${ }^{a}$ Cláudia: Acho que sim. Por parte da direção, acho que sim. Mais problema é da gente mesmo, né? É o receio de mexer com a tecnologia. É tecnofobia que fala? Tem professor que, dependendo do professor, tem medo de mexer por ele não conhecer as técnicas, como mexer, como estar usando e manuseando aquilo. Acho que ainda tem aquele medo de por a mão. Eu meto as caras. [risos] Eu vou assim, né? Eu vou observando, vou indo e, dependendo do aluno, até ele sabe mais que a gente, né? Então aprendo também com eles.

Pesquisador: É verdade. Você também dá aula em escola regular, certo?

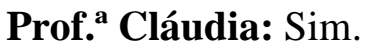

Pesquisador: Então, lá na escola regular, você integra as tecnologias às suas práticas?

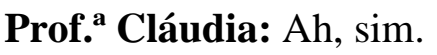

Pesquisador: Você planeja as mesmas atividades na escola regular e no EJA?

Prof. ${ }^{a}$ Cláudia: É diferente.

Pesquisador: E qual é a diferença?

Prof. ' Cláudia: Assim, quando é adolescente, eles caminham por si só. Em algumas coisas assim eles até avançam mais que a gente e até - como eu te falei - até auxiliam a gente. Essa é que é a grande diferença.

Pesquisador: Mas as atividades em si são as mesmas? Por exemplo, os jogos geográficos você desenvolve por lá também?

Prof. ' Cláudia: Faço. Eles também praticam.

Pesquisador: Mas tem coisa que você faz lá que não se adapta à EJA?

Prof. Cláudia: Depende também do aluno, da idade, do tempo, né?

Pesquisador: A questão do tempo atrapalha?

Prof. ${ }^{a}$ Cláudia: Do tempo, né? Porque aqui, como é a presença flexível, você nem sempre tem aquele mesmo aluno para dar continuidade, o que acho que é a dificuldade de desenvolver esse trabalho aqui. Vamos supor: eu começo hoje, marco uma pesquisa, se eu quero continuar com ela em um outro dia, eu já não vou ter o mesmo aluno. Eu vou ter alunos e grupos diferentes. Essa diferenciação que eu acho que dá uma quebra no trabalho.

Pesquisador: Você acha que o modelo do CEEJA dificulta esse tipo de atividade mais prolongada? 
Prof. ${ }^{a}$ Cláudia: Mais prolongada. Mas, assim, no caso dos jogos geográficos, a gente até consegue, né? Não consegue desenvolver como eu gostaria que fosse, com mais continuidade, mas dá aquele bloqueio, acho que é uma quebra. Mas, no mais, funciona.

Pesquisador: Então essa também é uma dificuldade? Podemos colocar a falta de continuidade como uma dificuldade do trabalho com tecnologias aqui no CEEJA?

Prof. ${ }^{a}$ Cláudia: É, falta de continuidade. Porque você começa lá com o jogo sobre coordenadas geográficas, você esta estudando latitude, a parte da longitude, vai trabalhar com meridianos relacionar com paralelos, né? Nessa parte, assim, o que eu quero aprofundar mais até chegar no GPS, para eu explicar essa parte, dá aquela quebra. Porque eu não vou ter o mesmo aluno para continuar. Acho que eu vejo assim.

Pesquisador: A partir do que estudamos no curso "Mídias Digitais na Educação de Jovens e Adultos", qual o papel das TDIC na formação para alunos jovens e adultos?

Prof. a Cláudia: Se há uma importância?

Pesquisador: Qual o papel das tecnologias na formação de alunos da EJA?

Prof. ${ }^{a}$ Cláudia: Na EJA hoje eu diria que é fundamental, né? Mesmo porque é fora, né? Não é só aqui. Porque a escola é um ambiente em que poderia ter mais. Mas eu digo que também é importante fora, para que os alunos tenham acesso. As redes sociais, os trabalhos de pesquisa que eles vão fazer em outros lugares. Eu acho que poderia ter mais, como se diz?

Pesquisador: Mais relação?

Prof. ${ }^{a}$ Cláudia: Isso. Mais relação e mais interação.

Pesquisador: Me dá um exemplo de um aspecto em que a formação do aluno poderia ter mais relação ou interação através das tecnologias.

Prof. ${ }^{a}$ Cláudia: Então, como eu te falei, o aspecto é que se eu quero trabalhar a questão de transgênicos, por exemplo, eu gostaria de ter essa interação com outros professores também. Eu vejo que isso é difícil mesmo.

Pesquisador: Quais são as necessidades de profissionalização para implementar a integração das TDIC na sua prática professoral? $\mathrm{O}$ que falta para que sejam totalmente integradas as tecnólogas nas suas práticas?

Prof. ${ }^{a}$ Cláudia: Nas minhas práticas? Acho que curso. Mas cursos assim. A gente tem o PROINFO, acho que o MEC oferece, né? E um ambiente adequado, com profissionais adequados. Porque não é só técnica. É assim: o prazer de você chegar e você também praticar. Eu acho que ainda falta essa parte. Porque você tem aquele curso que você chega lá e aprende isso, você tem a técnica, mas chega na hora de praticar é meia hora, uma hora e você sai dali e não tem aquela continuidade. Daí, se você quiser, como é meu caso, você vai ter que aprender sozinha, você vai buscar sozinha. E às vezes tem coisa assim que não, me faltou aquele item.

Pesquisador: Dentro daquilo que você consegue lembrar sobre o curso, quais foram as noções e temas que ficam para você a partir da leitura dialogal dos textos ao longo do curso "Mídias Digitais na Educação de Jovens e Adultos"?

Prof. ${ }^{a}$ Cláudia: Acho que foi aquela do Moran, que fala da - acho que foi você que falou da questão do uso da tecnologia em sala de aula, né? Do nosso receio de às vezes ter que estar trabalhando com ela. E acho que foi uma última coisa que você colocou, acho que foi o último texto, mas não lembro direito. Assim, relacionado mesmo a essa parte aí do uso das mídias 
em sala de aula. Ou seja, o meio, né? Meio. Ainda, em pleno século XXI, ainda é difícil. Eu vejo, eu fui nessa linha.

Pesquisador: Quais noções, temas e práticas estudadas no curso podem acontecer no contexto deste CEEJA?

Prof. ${ }^{a}$ Cláudia: Aqui. Acho que tudo pode, mas não depende só de estudar. Não sei dizer como. Algumas coisas acho que já até acontecem. Mas ainda tem muito medo que dificulta.

Pesquisador: Considerando o curso "Mídias Digitais na Educação de Jovens e Adultos", quais são os pontos fortes que devem ser mantidos e que aspectos você identifica como fragilidades, que devem ser alteradas numa segunda oferta da formação?

Prof. ${ }^{a}$ Cláudia: Assim, no meu caso, eu gosto muito de prática. Eu acho que a gente deveria ter colocado algumas coisas. A teoria é ótima, né? Mas como eu te falei, até a mesmo das questões do curso, pra gente, a prática. Eu acho que faltou. Para complementar, faltou a prática. Que nem esses dias a gente teve uma, veio a menina da diretoria de ensino e ela trouxe a vídeo-aula, né? Ela colocou lá e então eu fiquei assim. O receio de você. Eu tenho muita dificuldade de me expor. Gosto de falar assim em conversa, se tiver que fazer eu faço, mas então fiquei com medo, com receio, assim, sua imagem, como vai ficar. E também a parte que ela deu a teoria, mas ficou algumas coisas assim, pá pá pá, meio jogado, né? Então ficou assim. Falei: nossa, uma coisa tão interessante, que você pode até estar utilizando, né? Mas ainda não. Como eu te falei: a tecnofobia, fobia, o medo de você estar usando.

Pesquisador: Você então apontaria a falta da prática como uma fragilidade do curso?

Prof. ' Cláudia: Eu acho que a prática.

Pesquisador: Você achou tudo muito teórico?

Prof. ${ }^{a}$ Cláudia: Abrangeu bem, atingiu bem. Principalmente porque ajudou a despertar um monte de ações que antes não existiam. Não sei se é só o curso ou se é todo o incentivo que passou a ter. Eu já fazia, mas muitos não punham a mão e agora começam a por. Mas ainda é devagar mesmo, por conta de tudo que falei. Mas acho que precisa de uma coisa mais prática. Precisa ter a coisa da vivência, de você estar ali tirando suas dúvidas na hora: é isso ou é aquilo, né?

Pesquisador: Certo. E há algum outro aspecto a respeito do curso que não tenha sido perguntado até agora e que você queira comentar?

Prof. ${ }^{a}$ Cláudia: Que eu queira te perguntar?

Pesquisador: Comentar. Eu sei que já faz mais de um ano. Mas tem alguma outra coisa que marcou ou que poderia ser revista?

Prof. ${ }^{a}$ Cláudia: Acho que é isso mesmo. Espero ter ajudado, porque é difícil lembrar. Falei do que lembro, mas não lembro muito. Seria ótimo continuar falando sobre isso.

Pesquisador: Agradeço muito sua ajuda. Contribui muito para minha pesquisa.

Prof. ${ }^{a}$ Cláudia: Que bom! Eu que agradeço. 


\section{ANEXO E - TRANSCRIÇÃO DA ENTREVISTA - PROF. SILVANA}

É oportuno observar que a transcrição, na íntegra, dos depoimentos reproduz fielmente a coloquialidade característica da linguagem oral.

Entrevistada: Prof. ${ }^{a}$ Silvana Mussalim Guimarães (nome fantasia)

Entrevistador: Bruno dos Santos Joaquim

Transcrição: Bruno dos Santos Joaquim

Data: 28 de junho de 2016

Pesquisador: Agradeço a disponibilidade da professora em conceder esta entrevista e contribuir para a presente pesquisa. Os docentes participantes desta pesquisa terão seus nomes mantidos em sigilo, minimizando, desta forma, o risco de exposição dos mesmos.

Então vamos lá. Você faz uso das tecnologias digitais?

Prof. a Silvana: Sim.

Pesquisador: Quais? Em quais momentos? Pessoais, profissionais?

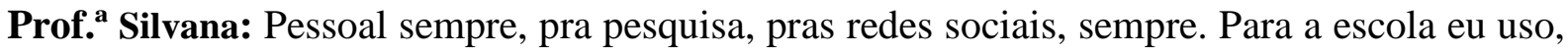
além do datashow, dos multimeios, eu utilizo, não, eu utilizei uma vez, que foi para fazer o fanfiction. Na verdade, interagindo mesmo com o aluno foi só o fanfiction. Já explico agora?

Pesquisador: Sim. Pode falar.

Prof. a Silvana: A ideia era eles produzirem um texto já dentro de uma página voltada para qualquer tipo de gênero. Então a gente, eu criei um gênero, dentro de uma data comemorativa, que a gente fez um trabalho com um filme da Frida. Eu comecei a história utilizando um fato que aconteceu e os alunos faziam vários parágrafos, lendo o que foi escrito, para treinar a leitura, e escrevendo, treinando a escrita também. Já escreviam direto na página do fanfiction. Eu cadastrei o nome da escola para eles poderem depois ter acesso ao texto completo.

Pesquisador: E fora isso houve alguma outra atividade com o uso das TDIC?

Prof. ' Silvana: Não. Eu uso outras coisas para trabalhar com eles, mas não que eles interajam usando a ferramenta. Aí não.

Pesquisador: Mas o que você tem como exemplo?

Prof. a Silvana: As oficinas, usando o áudio, usando vídeo, a gente usa muito filme. Curtametragem. A gente já fez alguns círculos de leitura com curta-metragem. Eles não interagem com a ferramenta, mas eles assistem, enfim.

Pesquisador: Bom. E você faz uso das tecnologias em suas práticas aqui do CEEJA? Você já falou de algumas. Algo mais a acrescentar?

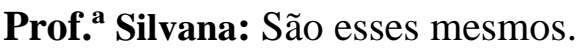

Pesquisador: Tudo bem. Há dificuldades para a promoção de práticas que fazem uso das TDIC? Se sim, ordene as principais dificuldades?

Prof. ${ }^{a}$ Silvana: A dificuldade é só que tem que ter um computador meu, né? Para usar na minha sala, sem ter que ir com o aluno para a sala de informática, porque nem sempre dá para sair. Isso limita um pouco. Mas claro, se eu fosse usar sempre a sala de informática, eu 
também limitaria os outros, que usam para pesquisa. Então, a única dificuldade é essa, você tem um único computador para vários alunos. Então, as atividades ficam limitadas. De vez em quando vai um aluno interagir.

Pesquisador: O número restrito de computadores na escola dificulta, então?

Prof. ' Silvana: Pelo menos na sala, né? Para fazer diariamente ou semanalmente essa atividade. Se não fica uma vez a cada semestre, enfim.

Pesquisador: Mais alguma outra dificuldade?

Prof. a Silvana: Assim, outra dificuldade que teve quando eu fiz esse trabalho com eles. No fundamental eles tinham a limitação de não terem ainda aprendido a produzir tanto um texto. $\mathrm{E}$ alguns, tanto do fundamental quanto do médio, não tinham, não sabiam lidar mesmo, eram analfabetos, não sabiam lidar com o computador, com o teclado, não sabiam o básico. E aí eu tive que ensinar. Mas como eram poucos.

Pesquisador: Isso é uma dificuldade também.

Prof. ${ }^{a}$ Silvana: Sim, é uma dificuldade, porque eles não têm esse acesso. Como a gente trabalha com pessoas de mais idade, então os que tinham mais idade tiveram muito mais dificuldade. Algumas senhoras, né? Teve um senhor que não sabia nada. Aí eu falava: "não, vai catando milho, mas você vai ter essa experiência que vai ser boa para o senhor". E ele gostou. Demorou muito mais. É uma grande dificuldade. Porque você já não tem o tempo, você só tem aquele espaço e aquele computador, então aquele aluno me tomou a tarde inteira para fazer um parágrafo. Isso sem você poder dar tanta atenção, porque você está fazendo isso junto com as provas.

Pesquisador: Então a questão do tempo também é um limite?

Prof. a Silvana: O tempo é.

Pesquisador: Então, entre essas três dificuldades: o pouco tempo, a falta de computadores e a dificuldade de parte dos alunos, qual você diria que é a principal?

Prof. ${ }^{a}$ Silvana: A falta da máquina, porque o resto a gente acaba se adaptando. A gente faz isso. A gente se adapta ao que a gente tem. Tanto que possível. Eu só demorei um pouco mais, porque eu achei que ia fazer em uma semana e durou duas, por causa dessas dificuldades. Mas não que não possa acontecer, pode. Você tem que dar mais atenção para aquele aluno que não sabe nada. Precisa falar: apera essa tecla, aqui é maiúscula, essa é minúscula. Até para ele ter contato mesmo, porque é importante para ele. Já que ele não tem contato fora, que seja aqui. Mas é uma dificuldade para um projeto. Se fosse uma coisa diária, já não poderia acontecer, não funcionaria. Enquanto um projeto, uma oficina, como foi a proposta, beleza. Mas se fosse uma coisa para ser feita sempre - o que seria legal, criar um texto dentro de um website é legal para eles, né? Eles se sentiram importantes vendo que está tudo publicado. Agora, só é viável se for um projeto, diário não. Nesse caso nosso, nessa nossa realidade.

Pesquisador: Você é professora de escola regular?

Prof. ' Silvana: Não. Só aqui mesmo.

Pesquisador: Ok. A partir do que estudamos no curso "Mídias Digitais na Educação de Jovens e Adultos", qual o papel das TDIC na formação para alunos jovens e adultos?

Prof. ${ }^{a}$ Silvana: Ai, caramba. Olha, como eu estava falando, se a gente tivesse realmente o espaço e o tempo, é a realidade, é o dia-dia do jovem. Dos mais velhos, não é o dia-dia o uso 
do computador, mas para os jovens é o dia-dia. Se a gente pudesse aliar sempre a tecnologia ao aprendizado, se tivesse ferramentas para isso, com certeza, acho que avançaria o dobro. A gente conquistaria o aprendizado deles em dobro. Mas na nossa realidade não. É só enquanto projetos, como a gente fez aqui. Mas, com certeza, o objetivo de tantas ferramentas, como você colocou no curso, eram tantas, não vou lembrar todas, né? Até o que a gente tem agora também. Não tive acesso. Eu mesma não tive tempo de procurar, mesmo depois de você mostrar. Eu também estou limitada ultimamente, por conta do meu tempo. Mas a gente tem um mundo de informações que a gente podia usar, para produção de texto, então, e para inglês muito mais, para inglês mais ainda. Eu mesma não tenho essa, eu não ampliei. Quantas coisas que você enumerou lá que a gente tem e eu não sabia, e não corri atrás. Como a gente não usa, não dá tempo de correr atrás. Com certeza, eu acredito que dobraria o aprendizado dos alunos, até desses que não tem acesso, né?

Pesquisador: Além de contribuir para a aprendizagem do aluno aqui na escola, o que mais o acesso às tecnologias poderiam contribuir para a formação do aluno aqui do CEEJA?

Prof. ${ }^{a}$ Silvana: Para vida dele, para o dia-dia, para a rotina, porque tudo agora a gente tem informatizado, desde retirar um dinheiro no banco, assistir à televisão, a linguagem agora é tecnológica. A gente é que não está acompanhando, né? Acho que mudaria a rotina mesmo do aluno, acompanharia o dia-dia. Aquele aluno que não tem, aquele aluno que é de uma classe um pouco mais pobre, que não tem acesso à nenhuma, ele é um analfabeto completo, porque ele não está aprendendo o mundo. O mundo está muito rápido, a tecnologia está muito rápida. Eu acredito que além daqui, do conteúdo, eu estava falando de conteúdo, além disso, acredito que avançaria na vida - como é que a gente fala? - profissional dele, enfim, social, porque as redes sociais estão aí, influenciam a vida deles e eles influenciam a vida de outros. Se você não tem uma linguagem, se não aprende a lidar com essa linguagem, você está boiando, está mais uma vez marginalizado. É mais uma forma de marginalizar, além das outras.

Pesquisador: Você acha que a falta de acesso torna o aluno excluído?

Prof. a Silvana: Excluído. É mais um tipo de exclusão. É só mais um tipo, além das outras tantas.

Pesquisador: E o papel da escola tem a ver com isso?

Prof. a Silvana: Totalmente, incluir em todos os sentidos, não só das limitações físicas e intelectuais, mas principalmente tecnologicamente, porque é o nosso mundo, né? Você vai falar em globalização. Todo mundo quer falar em globalização. Sem falar de tecnologia não está colando, né?

Pesquisador: Bom. Considerando o curso "Mídias Digitais na Educação de Jovens e Adultos", quais são os pontos fortes que devem ser mantidos e que aspectos você identifica como fragilidades, que devem ser alteradas numa segunda oferta da formação?

Prof. ${ }^{a}$ Silvana: Os pontos fortes, assim, eu não vou lembrar de toda a teoria que você passou, com certeza. Até porque algumas eu faltei também. Teve alguns ATPC daqueles que eu faltei. Mas eu acredito que eu senti falta de fazer a prática de algumas situações que você colocou. Então, alguns mecanismos, algumas ferramentas que você colocou que existiam, eu acredito que eu até fixaria, eu, pessoalmente, fixaria muito mais se eu tivesse visto na hora, se algum levasse um computador, por exemplo. Não sei se estou falando besteira. Eu não vou lembrar da teoria que você falou. Não vou mesmo. Mas acho que seria, não sei, uma segunda 
oportunidade em que cada vez que você colocar um exemplo, a gente pudesse olhar aquilo realmente dentro do universo lá, pelo menos eu, quando se fala em computador, em informática. De repente, fixaria muito mais. Não sei se os outros professores lembram mais do que eu. Depois de um ano é difícil.

Pesquisador: A ideia de todo esse tempo é também verificar o que ficou.

Prof. ${ }^{a}$ Silvana: Mas fica. Eu não vou saber te detalhar, mas o que ficou foi que você trouxe. $\mathrm{O}$ que foi legal? Você começou o trabalho, assim, da gente pensar nisso, para fazer essa oficina, por exemplo. Porque se não ia ser mais uma coisa que ia ficar para lá. E quando você fez o curso e sugeriu, a gente já foi pensando, já teve algumas ideias para unir à tecnologia ao aprendizado do aluno. Então, isso ficou, com certeza, a teoria toda eu não guardei. Eu guardei na hora lá, conforme você foi falando do que eu precisava para eu produzir a minha oficina. Agora, a teoria eu não vou lembrar.

Pesquisador: Quais são as necessidades de profissionalização para implementar a integração das TDIC na sua prática professoral? Ou seja, o que falta para que, do ponto de vista do seu trabalho docente, as tecnologia estejam totalmente presentes?

Prof. 'a Silvana: Falta mais curso de formação, com certeza, inclusive prático, né? Porque a gente tem os cursos, mas ficam teóricos. Teria que ter mais prática. De que maneira eu posso unir o inglês, sem ser o que eu acho que eu posso fazer? Precisa de profissionais tragam essas ideias do que já é feito, unindo a teoria dos cursos com o que a gente pode fazer aqui na nossa realidade. É curso. Tem que ter curso. Tem que ter estudo. Tem que ter a prática, a gente realmente. Não só uma oficina porque você propôs, né? Você pediu e a gente fez. Mas no diadia, a gente não consegue arrumar tempo para isso. E talvez, como no meu caso, por pura falta de habilidade mesmo. Eu sou desorganizada no meu tempo e por pura falta de habilidade. Até onde eu posso ir? Eu estou limitada. Nunca mais fiz, nunca mais tive nenhum curso voltado para tecnologia. $\mathrm{O}$ último foi o que você passou. Por fora não tem essa procura. Não faço. Então, falta mesmo estudo mesmo. É formação para a gente melhorar mesmo, porque a gente não tem. Acho que eu e ninguém. Eu estou falando pelos professores, porque ninguém tem. Se você não tivesse trazido, desde o último que você fez, eu não vejo ninguém ter falado que procurou outros cursos parecidos. Teria que ser assim mesmo, de fora para dentro.

Pesquisador: Bom. Se você não lembrar, pode falar, sem problemas, tá? Que noções e temas ficam para você a partir da leitura dialogal dos textos ao longo do curso "Mídias Digitais na Educação de Jovens e Adultos"?

Prof. ' Silvana: Ah, não vou conseguir lembrar. Isolado, assim, não lembro não. Porque conforme você ia falando eu já ia pensando no que ia fazer. A minha memória é péssima para guardar assim.

Pesquisador: Então, vou aproveitar e perguntar sobre a oficina desenvolvida em consequência do curso. De onde veio a ideia?

Prof. ${ }^{a}$ Silvana: Eu tive uma paciente que usava isso quando era adolescente. E aí eu achei legal, porque eu sou professora de línguas, né? Eu pensei não no inglês, eu pensei na nossa língua mesmo, porque a gente não tem a prática de escrever. Aí eu decidi unir a falta de prática de leitura e de escrita do aluno, mas com uma linguagem nova, que é uma página, um website com tantos outros gêneros. Eu escolhi, fiz um mote, aquele início, mas eu poderia ter deixado eles fazerem, cada um tipo de texto que quisesse. Porque o fanfiction a gente usou 
uma realidade nossa, mas a ideia é que você possa usar um personagem dentro de uma história que você goste, dentro de um filme, música ou qualquer área que você se encante. Você pode fazer uma história sobre aquilo sendo um personagem. A ideia é essa. Foi isso que eu pensei: ele é um personagem do próprio lugar em que ele estuda, para ele saber até que ele faz parte. Tanto que eles fizeram, um falava sobre e com o outro, não se conhecendo, mas falando como se tivessem dialogando, porque é o que acontece nos corredores do CEEJA. Então eles recriaram alguma vivência deles. É essa a ideia.

Pesquisador: E onde você viu a relação entre o curso e a Fanfiction?

Prof. ${ }^{a}$ Silvana: Por toda linguagem, né? A linguagem das redes sociais, você trouxe toda aquela linguagem nova, que está sendo usada, que eu desconhecia metade. Eu pensei numa dinâmica atual e quando você falava justamente isso, da gente trazer a teoria do uso da tecnologia para o computador, pras redes sociais. O Fanfiction acaba sendo uma rede social, só que de produção acadêmica. E eles não têm essa ideia. Inclusive tinham comentários lá. Já tinha uma pessoa que era lá do fanfiction e que fez comentários sobre o texto. Disse: "olha que ideia legal”. Deu parabéns para a escola. Eu coloquei quer era uma atividade de escola, coloquei o nome da escola como criador do texto. Mas eu pensei, assim, em unir a produção escrita, acadêmica, porque era uma coisa acadêmica, eram gêneros textuais, uma coisa que a gente aprende separado, com aquilo que você trouxe das linguagens tecnológicas mais atuais, das redes sociais, por exemplo. É o que aproxima mais o aluno, porque a gente acaba colocando muito termo técnico também e eles se distanciam denovo. Dizem: "eu não vou usar o computador, isso é muito difícil" ou "não sei usar". Principalmente nossos alunos adultos, né? Então trazer as redes sociais, que é uma coisa que eles podem interagir. Eu me lembro de uma aula que você deu em que você disse da dificuldade em se garantir direitos autorais, que tudo se compartilha quando joga na internet.

Pesquisador: Tá vendo como você se lembra de alguma coisa.

Prof. a Silvana: Pois é. [risos] E quando você joga na internet é de todo mundo. E isso é legal porque você pode interferir. Tanto que a gente colocou lá o texto dos alunos e um já interferiu elogiando, mas poderia ser um comentário sobre a produção deles, poderia ser como um blog, enfim. É que o blog o pessoal já usa mais, o fanfiction é mais específico para produção textual, ele é só para isso. E aí eu pensei nessa área, nisso que você falou. Mas falou muito mais que isso. Acho que para mim ficou mais essa parte, porque eu já devo ter associado com Fanfiction, já estava aqui numa repartição, num arquivo da memória.

Pesquisador: Bom. Há algum outro aspecto a respeito do curso que não tenha sido perguntado até agora e que você queira comentar?

Prof. ${ }^{a}$ Silvana: Não, eu nem consegui lembrar muita coisa. [risos] Eu lembrei mais dessa parte das redes sociais mesmo. Se for uma outra oportunidade, se você for refazer, que tenha uma parte mais prática pra gente fixar mais. É um problema meu assim, como usar a teoria. Acho que para lidar com a informática, não só com a informática, mas qualquer tecnologia, você tem que usar a prática. Você vai me ensinar a usar o datashow, se eu não fizer na hora, eu vou esquecer. Não sei, que o curso tenha alguma coisa a ver com a gente olhar na hora, fazer, abrir.

Pesquisador: Como você avalia sua adesão e a adesão dos demais professores ao curso? 


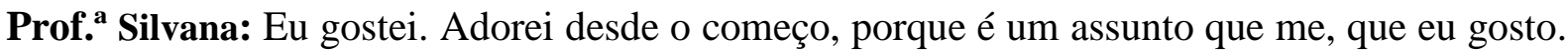
Pena que eu não tive tanto tempo para ficar buscando mais. Mas aquilo que eu falei, ainda bem que você trouxe, se não, não ia ter essa formação e eu não ia procurar fazer. De alguns colegas, eu acho que teve um pouco de resistência. Porque a gente vê que alguns colegas resistem ao uso mesmo até para si. Ainda tem professores que resistem. Eu tive dificuldades inclusive com colegas com resistência, porque a gente ia fazer a oficina com mais pessoas, e eu acabei fazendo sozinha por conta disso. Existiu essa resistência por parte de outros professores. Acho que é um medo de usar o computador, de ensinar para o aluno uma coisa que você não sabe. Para mim foi fácil ensinar aquilo ali que eu sabia, que era digitar um texto. Se eu tivesse que ter muito mais informação, eu também não ia inventar o que eu não sei fazer. Mas eu acho que teve uma resistência nesse sentido: "eu vou ficar com o computador e eu não sei usar essa tecnologia". Aí eu percebo que as pessoas deixaram de aproveitar um pouco pela resistência mesmo, da idade. Os professores mais antigos, alguns, são mais resistentes mesmo.

Pesquisador: Só os mais antigos?

Prof. ' Silvana: Deixa eu pensar. Bom, mas daí é preguiça, né? Existe a preguiça dos mais antigos também em aprender. Porque se você está no meio da educação, não tem como não meter a cara na tecnologia. Você não saber ligar um aparelho de datashow, ter sempre que ter alguém para fazer isso para você. Tenta, né? Existe a preguiça, tá? Eu sou resistente, mas até onde eu sou resistente ou eu sou preguiçoso? Enfim, aí são outros quinhentos. Não sei se dos jovens teve também, não parei para pensar. Acho que eu tive contato com os mais antigos, que prejudicaram, mas depois acabou dando certo porque eu fiz sozinha. Foi chato, mas saiu. Talvez não saísse do jeito que eu pensei se tivessem outras pessoas envolvidas, né? Depois eu fiquei pensando nisso também. Muita gente mexendo num texto assim, acho que também ia ser difícil.

Pesquisador: Pode ser que o curso não tenha mobilizado a todos.

Prof. ${ }^{a}$ Silvana: Mas isso é próprio de escola pública, Bruno. Isso é a cara da escola pública. Alguns professores estão acomodados esperando aposentar. Eu estou louca para aposentar, mas não vou ficar esperando sentada. O tempo não passa. Mas isso é uma característica da própria escola pública. Não é porque aqui a gente faz coisas com mais facilidade que no regular. No regular talvez eu não fizesse. Não fazia. Eu acho que isso é uma característica da escola pública. Você sempre vai ter metade envolvida e outra metade não em qualquer situação. A gente vê pelos eventos que a gente faz aqui. Quantas pessoas se envolvem? E o tema até diz respeito ao seu dia-dia, enfim. Quantas se envolvem? E aí não tem nem tecnologia, são temas que você conhece, do seu dia-dia, são temas de direitos humanos, de relações. É uma prática da escola pública, independente de ser regular ou não. E aqui é um espaço mais fácil, né? Mas nem aqui todas as pessoas se envolvem quando não tem interesse, porque são acomodadas. E aí eu digo que não é o curso que vai mobilizar. Você pode vir aqui e dar aula de cabeça para baixo que as pessoas não vão se interessar, porque não se interessam mesmo, querem ver o bonde passar. Eu penso assim. Com raríssimas exceções e são sempre as mesmas pessoas que você vai contar. E são sempre as mesmas pessoas que você tem que cutucar, que são mais acomodadas, né? Não é que não fazem, mas fazem com aquele peso, né? Não curte o que está fazendo. Mas isso é típico da escola pública. Se você fizer esse curso 
em uma escolar regular EJA, você vai ter aqueles dez por cento lá dedicados, fazendo com empenho, uns trinta mais ou menos e cinquenta porque foram obrigados. Sei lá se fiz a conta certa. Faltou mais dez, né? Enfim, você entendeu, né?

Pesquisador: Entendi. Está bom. Muito obrigado pela contribuição nessa pesquisa.

Prof. ' Silvana: Respondi tudo? Ajudou?

Pesquisador: Ajudou muito. Muito obrigado. 


\section{ANEXO F -ENTREVISTA - PROF. MARIA}

É oportuno observar que a transcrição, na íntegra, dos depoimentos reproduz fielmente a coloquialidade característica da linguagem oral.

Entrevistada: Prof. ${ }^{a}$ Maria Peregrino de Fátima Rotta (nome fantasia)

Entrevistador: Bruno dos Santos Joaquim

Transcrição: Bruno dos Santos Joaquim

Data: 29 de junho de 2016

Pesquisador: Agradeço a disponibilidade da professora em conceder esta entrevista e contribuir para a presente pesquisa. Os docentes participantes desta pesquisa terão seus nomes mantidos em sigilo, minimizando, desta forma, o risco de exposição dos mesmos.

Na sua vida como um todo, você faz uso das tecnologias?

Prof. 'Maria: Faço muito.

Pesquisador: Me dá exemplos.

Prof. ${ }^{a}$ Maria: Eu uso muito o computador para fazer compras, pagar contas, trabalhar, redes sociais. Falo muito com minha família e meus amigos pelas redes sociais.

Pesquisador: E você faz uso de tecnologias digitais nas suas práticas pedagógicas aqui no CEEJA?

Prof. ${ }^{a}$ Maria: Sim. Eu trago sempre meu computador para cá. É mais prático. Entre um aluno e outro estou no computador trabalhando.

Pesquisador: Trabalhando como?

Prof. ${ }^{a}$ Maria: Principalmente pesquisando, elaborando prova, montando PowerPoint, pesquisando vídeos para as oficinas. Uso para isso mesmo. Também uso, às vezes, para me comunicar com algum aluno. Quando um aluno some, mando uma mensagenzinha pelo Facebook. Eles ficam felizes e acabam voltando.

Pesquisador: E você utiliza em alguma atividade direta com o aluno?

Prof. ' Maria: Nas oficinas e também indicando o vídeo para que ele possa, como se diz, "EJA mundo do trabalho". Esses vídeos ajudam os alunos. Eles não são essenciais. Eles contextualizam um pouco mais. Sabe que a Física é assim, né? Se não contextualizar, para eles, é muito difícil.

Pesquisador: E nas oficinas?

Prof. ${ }^{a}$ Maria: Também, através dos vídeos. Os vídeos que nós pesquisamos, utilizamos para complementar o que foi, o que vai ser falado na oficina. Eles deixam mais dinâmico.

Pesquisador: E quanto ao simulador?

Prof. a Maria: Verdade. Foi uma ideia do [nome suprimido]. Usamos na oficina sobre astronomia. Os alunos gostaram, porque conseguem ver o que nem sempre conseguem ver olhando no telescópio ou a olho nu. Você assistiu a essa oficina, né? Não foi legal? Um aluno me disse que instalou no celular dele para ficar vendo. 
Pesquisador: E você acha que há dificuldades para a promoção de práticas que fazem uso das TDIC?

Prof. ${ }^{a}$ Maria: Na oficina não. A internet cai muito, né? Atrapalha quando a gente precisa usar e fica caindo. Mas fora isso. A escola ajuda também, porque aqui no CEEJA a gente tem um pouco mais de tempo para isso. Aqui dá para gente planejar, planejar coletivamente, até com outros professores, de outras disciplinas. Mas acho que a gente faz pouco. Podia ter mais, já que é mais fácil fazer aqui. Dou aula no particular também, aqui é mais fácil e temos mais apoio, seu apoio, apoio da direção. Mais que apoio, vocês valorizam. Por isso acho que a gente faz pouco.

Pesquisador: Mas você acha que esses professores tem alguma dificuldade em fazer esse uso? Por que você acha que se faz pouco?

Prof. ${ }^{a}$ Maria: A dificuldade é a falta de motivação mesmo, vontade. Eu mesma tento, vou tentando fazer. Não faço muito, mas faço o que eu sei só. Mas tem gente que sabe muito, mas faz pouco. E tem gente que não sabe também. Aquilo que eu acho que dá para fazer na minha disciplina, a gente planeja e faz.

Pesquisador: Falta formação?

Prof. ${ }^{a}$ Maria: Falta formação. Falta, mas quando tem o pessoal não valoriza. Sabe como é, né? O coordenador tenta, planeja, cria, mas o professor vê como castigo. Eu tento me dedicar. $\mathrm{Na}$ formação eu faltei um ou outro dia. E também não li tudo aquilo. Mas achei a iniciativa muito boa.

Pesquisador: Legal. Você também é professora de escola regular?

Prof. ${ }^{a}$ Maria: Sou sim. Do colégio [suprimido].

Pesquisador: Você integra as TDIC às suas práticas escolares lá? E teve alguma atividade que você planejou para lá e que tentou trazer para o CEEJA?

Prof. ${ }^{a}$ Maria: Não. São realidades diferentes. Acho que até daria. Por exemplo, os vídeos, o simulador, acho que não. Os vídeos eu uso, usava. Eu usei alguns lá e aqui o ano passado. A gente explica de forma diferente, porque aqui os alunos são muito diferentes, né? Muitas idades diferentes, às vezes pouca base. Os vídeos servem para ilustrar, aproximar o aluno da matéria. Lá eu usava também, mas como uma aula expositiva. Aqui o vídeo é ou para a oficina, ou para o aluno explicar, quer dizer, entender melhor o que está vendo.

Pesquisador: A partir do que estudamos no curso "Mídias Digitais na Educação de Jovens e Adultos", qual o papel das TDIC na formação para alunos jovens e adultos?

Prof. a Maria: É importante para todos. É importante para mim, para você, para os professores, para a criança, o jovem, o adulto, o idoso. Tecnologia é fundamental. Mesmo aqueles que não tem tanta condição financeira hoje se esforça para ter um celular, quer a senha do nosso wifi. Sinal de que reconhece que é importante. A gente tem que incentivar. Se a gente pensar, isso tem relação com a vida pessoal dele, com a felicidade. Tem relação com o emprego dele também, né?

Pesquisador: Considerando o curso "Mídias Digitais na Educação de Jovens e Adultos", quais são os pontos fortes que devem ser mantidos e que aspectos você identifica como fragilidades, que devem ser alteradas numa segunda oferta da formação?

Prof. ${ }^{a}$ Maria: Não, eu acho que o formato foi interessante. Teve uma parte prática, né? Mas foi pouco. O ponto forte é a iniciativa, o conhecimento trazido. A gente não leu tudo. Eu, pelo 
menos, não li quase nada. Mas participei das discussões. Participei do debate, ajudei a pensar tudo aquilo para nossa realidade aqui. Porque nem tudo se aplica, né? E isso que falta, ponto fraco, não teve a participação, a dedicação total dos professores, como merecia ter. Faltou ver a coisa acontecendo, exemplos práticas, experiências que deram certo. Talvez desse para fazer aulas de exemplo. Uma segunda oferta, né? Isso é uma boa para o outro.

Pesquisador: Quais são as necessidades de profissionalização para implementar a integração das TDIC na sua prática professoral? O que falta?

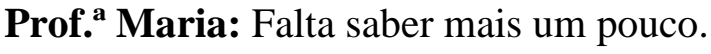

Pesquisador: Formação?

Prof. ${ }^{a}$ Maria: É, principalmente, como eu falei, a gente ver exemplos, assistir uma aula, uma oficina que usasse tecnologia. A direção teve a ideia de usar os ATPC para fazer umas oficinas, tipo, o professor dando aula pro outro. Eu acho bom. O professor que usa, mostra como. A gente aprende vendo alguém fazer e fazendo. É uma outra ideia para novos exemplos, novos cursos.

Pesquisador: Que noções e temas ficam para você a partir da leitura dialogal dos textos ao longo do curso "Mídias Digitais na Educação de Jovens e Adultos"?

Prof. ${ }^{a}$ Maria: Não lembro tudo. Mas claro que fica sempre alguma coisa. Aquele negócio dos recursos abertos. Aquilo é muito bacana. Foi assim que montamos a oficina, o simulador, que a gente até já conhecia, mas não tinha pensado como um. Tem muita coisa lá, né? A gente viu. Não vimos tudo, porque é muito e tem que ter tempo de procurar, de fuçar. Isso dos recursos eu me lembro.

Pesquisador: Mais algum?

Prof. ${ }^{a}$ Maria: Acho que não. Sim. Assim, toda aquela discussão da desigualdade. Uns com acesso, outros sem. Isso marcou porque discutimos com dados, números. Sou de exatas, isso faz sentido, né? Acho que lembro bem dessa aula. Lembro dos recursos e dessa fala assim.

Pesquisador: E você vê possibilidade de implementar esses conceitos e noções aqui no CEEJA?

Prof. ${ }^{a}$ Maria: Sim. Os recursos já estão. Não muito. Não como deveria. Mas já estão aí. Sei que geografia está usando, química. Agora, o outro, o da desigualdade, exclusão, inclusão digital, isso é nosso dia-dia. A gente está aqui com a pessoa excluída mesmo, já excluída desde criança. Então é preciso levar isso em conta

Pesquisador: Tem algum outro aspecto a respeito do curso que não tenha sido perguntado até agora e que você queira comentar?

Prof. ${ }^{a}$ Maria: Tem que ter outro para gente ler os textos que não leu. [risos] Eu preciso. Gosto muito do assunto. Acho que tem tudo a ver comigo, porque estou sempre com algum aparelho, sempre conectada de alguma forma.

Pesquisador: Então você acha interessante que acontecesse denovo.

Prof. 'Maria: Claro! Com certeza. Esse tipo de coisa, ainda mais quando tem que aplicar, motiva, tira a gente do lugar um pouco. Precisa.

Pesquisador: Legal. É isso! Obrigado, professora!

Prof. ${ }^{a}$ Maria: Imagina. Quando precisar. 


\section{ANEXO G -ENTREVISTA - PROF. LUIZ ROBERTO}

É oportuno observar que a transcrição, na íntegra, dos depoimentos reproduz fielmente a coloquialidade característica da linguagem oral.

Entrevistado: Prof. Luiz Roberto Marighetti (nome fantasia)

Entrevistador: Bruno dos Santos Joaquim

Transcrição: Bruno dos Santos Joaquim

Data: 23 de junho de 2016

Pesquisador: Agradeço a disponibilidade do professor em conceder esta entrevista e contribuir para a presente pesquisa. Os docentes participantes desta pesquisa terão seus nomes mantidos em sigilo, minimizando, desta forma, o risco de exposição dos mesmos.

Eu vou seguir um roteiro de entrevista. Você deve ficar a vontade para responder o que quiser.

Prof. Luiz Roberto: Tudo bem.

Pesquisador: Primeira pergunta: você faz uso das tecnologias digitais?

Prof. Luiz Roberto: Em termos

Pesquisador: Quais termos?

Prof. Luiz Roberto: Não. Olha, poderia fazer mais, né? Poderia fazer mais, mas ainda não acho que faço em bom número. Pelo menos aqui nesse espaço. Talvez na escola regular eu consiga utilizar mais. Não tem muita estrutura e tudo mais, mas aqui, como espaço educativo ainda não vingou.

Pesquisador: E fora do espaço escolar, em sua vida pessoal?

Prof. Luiz Roberto: Faço. Exemplos? Faço em termos de redes sociais e tudo mais, eu faço. Agora, voltando, em escola regular, eu consigo mais do que no EJA.

Pesquisador: Você faz uso de tecnologias digitais nas suas práticas pedagógicas aqui no CEEJA?

Prof. Luiz Roberto: Não.

Pesquisador: Nada?

Prof. Luiz Roberto: Não. Da tecnologia não.

Pesquisador: Há dificuldades para a promoção de práticas que fazem uso das TDIC?

Prof. Luiz Roberto: Não.

Pesquisador: Nenhuma dificuldade?

Prof. Luiz Roberto: Será? Eu preciso pensar. Que coisa horrível, né? Eu acho assim, não existe dificuldade, bom, de técnica, talvez um pouco, não muito. Tem sim, técnica, muito mais do que uma restrição administrativa, entendeu? Administrativamente, eu acho que o espaço permite muito mais do que a gente faz. Técnica talvez nem tanto.

Pesquisador: Mas o que você que dizer com técnica? 
Prof. Luiz Roberto: Recursos técnicos, né? Tecnológicos. Estrutura e tudo mais. A nossa estrutura é mínima. Mas o que falta mesmo que eu vejo é uma busca da utilização disso.

Pesquisador: Iniciativa?

Prof. Luiz Roberto: A iniciativa sim. Porque você conhece algum - como que eu posso chamar? - meios, não, - qual o nome, por favor? - você conhece alguma tecnologia, as mídias, você conhece ou meio que conhece, não há uma restrição administrativa para tanto, tecnologicamente você tem alguns limites, mas o que falta mesmo é iniciativa. No meu caso é falta de iniciativa mesmo. Quer dizer, eu não consegui pensar ainda, apesar de todo esse processo e de várias discussões que a gente teve em torno disso, ainda falta aquela coisa de você inserir no seu cotidiano, né? Então, eu ainda não consegui inserir em meu cotidiano da forma que eu acho que poderia ser. Eu acho assim, só para abrir um parêntese. Agora com a participação na comissão de formatura que a gente está usando muito essa questão. Whatsapp que é só bobeira, você percebe que em alguns momentos alguns alunos utilizam para fazer perguntas de outras coisas, até relativo ao, estava estudando para prova tal. Então aí você percebe o canal até está aberto, ele só não está sendo utilizado.

Pesquisador: Para as práticas pedagógicas?

Prof. Luiz Roberto: Sim, para as práticas pedagógicas.

Pesquisador: Então se você fosse ordenar as dificuldades, a iniciativa seria a principal?

Prof. Luiz Roberto: Acho que iniciativa é o principal por dois motivos. Um por uma questão mesmo de iniciativa e outro pela questão do desconhecimento. No meu caso, eu não vou dizer que seja desconhecimento. Eu preciso mesmo parar e pensar em como estruturar isso.

Pesquisador: Você colocaria infraestrutura também como um fator?

Prof. Luiz Roberto: Sim.

Pesquisador: Mais algum outro?

Prof. Luiz Roberto: Falando da minha realidade.

Pesquisador: Sim, sua visão.

Prof. Luiz Roberto: Não. Eu não acho que administrativamente a gente tenha algum problema nesse sentido. Se por exemplo, se de repente eu criar uma parte do meu trabalho online ou, sei lá, você abrir um clube, clube não, um grupo no Whatsapp, ou um blog, eu não acredito que teria, desde que legal, não teria problema administrativo. Não é?

Pesquisador: Você é professor também de escola regular?

Prof. Luiz Roberto: Sim.

Pesquisador: E você integra as TDIC às suas práticas escolares lá?

Prof. Luiz Roberto: Hoje sim.

Pesquisador: E aqui no CEEJA você planeja as mesmas atividades que você leva para lá?

Prof. Luiz Roberto: É. Eu acho que hoje eu posso. Assim, o tempo que eu tenho de CEEJA é curto. Então eu estou assim, tateando. Mas acho que hoje eu consigo colocar algumas coisas. Eu até estava pensando. Eu fiz um trabalho com os alunos, de um blog que eu tenho, e que eu posso estar utilizando gradativamente dentro do CEEJA. Então eles têm que entregar. Hoje o que a gente tem? O aluno tem uma avaliação com oito pontos, uma prova escrita, e uma tarefa que ele escreve e a gente anexa. Isso poderia ir para a sala, nosso laboratório, e o cara digitar e mandar, ele ter essa opção de fazer. Ou a sala de informática aqui da escola ou utilizar a casa, 
o ambiente que ele quiser. Mas é um caminho. Inclusive estava conversando isso com o [nome suprimido].

Pesquisador: Explica melhor essa atividade com blog que você desenvolve lá.

Prof. Luiz Roberto: Ele faz uma atividade online. E aí publica. E aí, assim, chega até a ser uma avaliação com eles. Mas já não com essa turma, já em uma outra realidade. Faz a avaliação no blog, eles vão e fazem. Porque aí não libera as respostas, você tem como segurar lá as respostas. Aí só depois que venceu a data de postagem é que libera os comentários deles.

Pesquisador: Entendi. A partir do que estudamos no curso "Mídias Digitais na Educação de Jovens e Adultos", qual o papel das TDIC na formação para alunos jovens e adultos?

Prof. Luiz Roberto: Aqui?

Pesquisador: Sim. E também na EJA em geral.

Prof. Luiz Roberto: É que aqui a gente tem uma amplitude muito de perfil de aluno, né? Então, você tem aluno que chega aqui e que já está integrado à essa linguagem, à essa tecnologia toda. Agora, para boa parte deles seria inseri-los, precisaria de um processo de alfabetização, que parta aí do mundo digital, ou parte dele. Uma alfabetização para o mundo digital até o cara conseguir entender, entender os procedimentos, não só os procedimentos, mas ele é importante para você até regrar e tentar formar um utilizador dessas tecnologias dentro de um parâmetro. Não sei, acho que isso é complicado de falar. Porque não é só introduzir a tecnologia, apresentar para ele uma alfabetização digital, mas também um bom uso disso.

Pesquisador: E o que seria um bom uso?

Prof. Luiz Roberto: Um bom uso seria um uso adequado dessas tecnologias. Acho que isso a gente pode também, principalmente quando a gente está falando de redes sociais. Eu acho assim, não dá pra separar uma coisa da outra. Você alfabetiza e precisa também mostrar os limites, ensinando essa coisa do que é viver no mundo virtual, né? Não sei. Eu tenho essa ideia de que talvez fosse importante neste sentido.

Pesquisador: Você acha que é papel da escola?

Prof. Luiz Roberto: Também é esse. Então eu acho que, pensando assim, claro que para os nossos alunos mais novos, que já estão integrados, talvez uma discussão, e a gente já teve até a oportunidade de fazer uma oficina discutindo isso, orientar no sentido de entender o que é viver no mundo virtual. Agora, no caso dos mais velhos, realmente essa alfabetização deveria ser a introdução.

Pesquisador: Você que públicos diferentes precisam de trabalhos diferentes?

Prof. Luiz Roberto: Precisa. Trabalhos diferentes, claro.

Pesquisador: Considerando o curso "Mídias Digitais na Educação de Jovens e Adultos", quais são os pontos fortes que devem ser mantidos e que aspectos você identifica como fragilidades, que devem ser alteradas numa segunda oferta da formação?

Prof. Luiz Roberto: Eu acho assim, na verdade, o que compromete um curso como foi esse não é nem a proposta do curso, é a disciplina de quem está fazendo em receber o material antecipadamente e abri-lo e explorá-lo. Porque muitas vezes, eu percebo assim, só por você ter um curso e o curso estar estruturado - não vou ficar fazendo elogios. Mas o que acontece? Porque como ele é um tema extremamente atual e muito discutido, as pessoas acham que dá para, sabe, entrar na discussão sem essa leitura. E a leitura, o material que o curso propôs ele é 
muito mais rico do que a gente possa, sei lá. A discussão poderia ser mais rica se ela ficasse centrada nesse material. Então eu não sei como seria o caminho melhor. É que eu falo por mim. Eu cheguei em momentos que eu não tinha lido o material. E tem texto que não li ainda, tá? Deixa isso registrado aí. Tem texto que eu ainda não li e sei que eu preciso retomar isso, porque, para sair desse achismo ou então de uma única visão. Mas acho legal ter uma nova proposta desse curso. Seria bom.

Pesquisador: Vamos pensar, no futuro. Quais são as necessidades de profissionalização para implementar a integração das TDIC na sua prática professoral? Ou seja, o que ainda falta para você integrar totalmente as tecnologias nas suas práticas?

Prof. Luiz Roberto: Você está pensando em escola regular ou aqui?

Pesquisador: Na sua prática como um todo.

Prof. Luiz Roberto: É assim, eu sei que discurso de professor vira lugar comum, né? A dinâmica muitas vezes acaba limitando bastante. Eu estou falando da dinâmica de vida do professor mesmo. Aquele coisa, sabe? Daria até para fazer alguma coisa, mas também acho que essa não é a discussão. Eu acho, assim, que é fazer. É fazer. Eu acho que a gente precisa. A gente está muito preso, né? Eu falo assim, eu tenho e estou muito preso eu tento às vezes. Primeiro essa centralização na figura do professor. Não que você utilizando essas mídias você não tenha essa centralização. Mas a sensação é de que você perdeu o domínio. E eu acho, assim, que a centralização é um problema sério, mas é, sei lá, o fazer mesmo, é arriscar, é entender que é possível, sair um pouco desse lugar comum da aula expositiva, em que tudo se resume à presença do professor, à presença física do professor, né? Na verdade precisa se habituar com a linguagem virtual. Eu não. Ainda tenho muita resistência, apesar de já ter dado alguns passos e tal, eu ainda, vivo ainda uma realidade real. Talvez eu ainda esteja na caverna do Platão.

Pesquisador: Por que você acha isso?

Prof. Luiz Roberto: É porque o mundo virtual é, sabe, é uma realidade. Eu estou aqui com as sombras agora, porque existe uma linguagem muito mais dinâmica, muito mais estimulante, uma linguagem que eu preciso utilizar, e que dá conta muito mais, principalmente pensando na escola regular e pensando no mundo como um todo, é a linguagem do momento. Então, um pouco da aula se torna maçante, se torna cansativa, porque não integra uma linguagem que seja mais acessível. Ainda ontem, conversando com outra professora, eu estava falando disso. A necessidade que eu tenho para escrever do papel e da caneta, certo? E existe uma geração agora. Quer dizer, eu consigo produzir texto no teclado? Até consigo. Mas eu fico travado, é muito mais fácil quando estou com caneta e papel. Eu estou muito preso a isso. E existe uma geração agora. Eu não consigo, no celular eu não consigo fazer texto.

Pesquisador: Mas você atribui à geração ou é uma questão de formação?

Prof. Luiz Roberto: Formação. Quando eu estou falando de geração, é formação. Porque, assim, é aquela coisa de você estar preso à sua base, né? A sua base. E talvez isso elimine muitos problemas de embate em sala de aula seja no EJA ou lá. No nosso caso o embate é talvez uma palavra muito pesada. Mas mesmo no EJA ou na escola regular, eu acho assim, eu preciso entender que vem vindo uma nova formação, uma nova realidade, eu que eu preciso integrar isso. Então eu preciso, nesse sentido que eu falei que preciso sair da caverna, porque 
eu estou lá nas sombras, né? Não que essas sombras não sejam reais também. Não vai muito lá para o filosófico, para Platão, se não eu me perco.

Pesquisador: Falando sobre o curso especificamente, agora. Que noções e temas ficam para você a partir da leitura dialogal dos textos ao longo do curso "Mídias Digitais na Educação de Jovens e Adultos"?

Prof. Luiz Roberto: Agora vai dar. Espera aí. Preciso lembrar. Posso olhar meu e-mail?

Pesquisador: Não precisa, tenta falar o que você se lembra. Se não lembrar de nada, tudo bem.

Prof. Luiz Roberto: Acho que eu não lembro nada não.

Pesquisador: Não tem problema.

Prof. Luiz Roberto: O texto do empoderamento eu achei legal. Esse talvez - se eu tiver errado você me fala - mas do empoderamento falava justamente dessa questão da alfabetização. Não sei se o texto falava bem isso. Mas a questão da introdução nesse mundo digital e do quanto a exclusão te deixa fora de muitas realidades e tal. Eu acho que foi isso. Mas eu não lembro bem não. Vou ser sincero. Eu vou buscar. Acho que eu devia ler esses textos. Mas eu já tinha dito para você que um dos problemas do curso era esse, o de se dedicar tempo para leitura dos textos, aí você fica esperando a explanação, porque a explanação sempre vem. E aí, sem a leitura, você vai trabalhar só com uma memória auditiva, aí não dá.

Pesquisador: Claro. E dessas discussões, noções, temas e práticas estudadas no curso, quais podem acontecer no contexto deste CEEJA? Pense no pouco que você se lembra.

Prof. Luiz Roberto: O que pode ser trabalhado no contexto do CEEJA?

Pesquisador: Sim. O que pode ser trazido para o CEEJA?

Prof. Luiz Roberto: Trazido? Vamos pensar assim, eu acho que tudo pode ser trazido a partir de um momento. Talvez, olha, agora você veja bem como uma coisa acaba casando com a outra, tá? Por que não há uma introdução o CEEJA? Aí eu vou, você viu que a minha leitura disso tudo. Eu estava no curso, eu acompanhei, eu participei, mas não como eu deveria. Então, na verdade, eu não estou munido. Agora fazendo uma leitura crítica para minha pessoa, aí talvez a iniciativa. Lembra que você me perguntou qual era o maior problema, a maior dificuldade? Talvez o maior problema e a maior dificuldade seja a iniciativa. Porque? $\mathrm{O}$ que eu retive do curso? A dificuldade que eu estou tendo de buscar o texto e tal. Eu me lembro de temas, me lembro de palavras, mas talvez faltou eu ter essa base para deixar claro: tem que fazer isso, isso e aquilo. Agora, eu analisando a minha falta de iniciativa, ela não pode ser pensada pelo tempo, mas pela falta de base mesmo. Ai vem a pergunta: como é que eu vou trabalhar com o outro e tentar alfabetizar introduzir o outro, se a minha base também não está legal? Nossa. Agora joguei pedra em mim.

Pesquisador: Mas é uma boa reflexão.

Prof. Luiz Roberto: Olha, tudo conduziu a isso. A lógica desse questionário é muito interessante, porque é difícil você fugir disso quando chega ao final, descobrir que o problema está em mim, enquanto professor. Certo? Uma boa parte dele está mesmo. Que dizer, como eu não me importei como aluno de um curso de formação, o que eu trouxe desse curso de formação?

Pesquisador: Mas você acha que não absorveu nada? 
Prof. Luiz Roberto: Não, eu incorporei. Eu até trouxe. Não é o curso, sou eu. Quer dizer, então, o que eu trouxe daquilo para minha prática? Entendeu? Não porque o curso não oferecia.

Pesquisador: Mas me parece que parte dele está presente no seu discurso.

Prof. Luiz Roberto: Sim. Está. Mas não atingi a etapa de colocar em prática. Então, talvez retomar essa leitura. Aí, voltando, reforça a ideia da necessidade de retomar a leitura do curso. Porque ele ficou teórico lá. Mas na prática não, entendeu?

Pesquisador: E para encerrar, tem algum outro aspecto a respeito do curso que não tenha sido perguntado até agora e que você queira comentar?

Prof. Luiz Roberto: Tem um aspecto ruim, muito ruim. Essa entrevista tinha que ser mais perto dele. [risos]

Pesquisador: Mas precisa ter um tempo de maturação, né? Senão seria uma coisa muito mecânica, você ia repetir o que acabou de ouvir. A ideia de dar esse tempo é exatamente ver o que ficou.

Prof. Luiz Roberto: Você sabe que eu até pensei. E foi legal não ter feito isso e nem tive tempo. Porque quando você me convidou, a ideia que eu tive foi: deixa eu retomar o curso, os textos. Mas acho que fica muito mais real dessa forma.

Pesquisador: A ideia é essa. Bom que você não fez isso.

Prof. Luiz Roberto: Sim, sim. Acho que fica muito mais verdadeiro, né?

Pesquisador: Bom, mais algum outro aspecto sobre o curso?

Prof. Luiz Roberto: Acho que é só isso. Deixa eu pensar. Só isso mesmo.

Pesquisador: Então muito obrigado pela contribuição.

Prof. Luiz Roberto: De nada. Desculpa por não lembrar muito.

Pesquisador: Imagina. Agradeço muito pela ajuda. 


\section{ANEXO H -ENTREVISTA - PROF. VINÍCIUS}

É oportuno observar que a transcrição, na íntegra, dos depoimentos reproduz fielmente a coloquialidade característica da linguagem oral.

Entrevistado: Prof. Vinícius Xavier Zammataro (nome fantasia)

Entrevistador: Bruno dos Santos Joaquim

Transcrição: Bruno dos Santos Joaquim

Data: 24 de junho de 2016

Pesquisador: Agradeço a disponibilidade do professor em conceder esta entrevista e contribuir para a presente pesquisa. Os docentes participantes desta pesquisa terão seus nomes mantidos em sigilo, minimizando, desta forma, o risco de exposição dos mesmos.

Primeira pergunta: na sua vida como um todo, você faz uso das tecnologias?

Prof. Vinícius: Faço. Eu faço uso dentro das minhas limitações, porque eu não tenho aquele domínio absoluto. Sou de uma geração que tem um pouco mais de dificuldade de dominar extensivamente a tecnologia, mas procuro, na medida do possível, até porque onde eu trabalho, sobretudo eu trabalho com ensino fundamental lá, a gente utiliza um pouco mais até do que aqui.

Pesquisador: E quais tecnologias você utiliza? Me dá um exemplo.

Prof. Vinícius: Não, basicamente, você falou do que? Em relação à internet?

Pesquisador: De exemplos do que você faz com uso de tecnologias.

Prof. Vinícius: Pesquisa, busca, sites de buscas, redes sociais também utilizo.

Pesquisador: Ok. E você faz uso de tecnologias digitais nas suas práticas pedagógicas aqui no CEEJA?

Prof. Vinícius: Na verdade, para mim, diretamente para mim, eu faço bastante, no sentido de pesquisas, né? Pesquisas, preparação de oficinas, de palestras, essas coisas. Indiretamente, no sentido de sempre estimular o aluno a pesquisar, a aprofundar o assunto, direcionando, utilização dos instrumentos da escola, do aparelhamento da escola, nesse sentido. Porque eu acho que eles, principalmente o pessoal que é menos refratário ao uso da tecnologia, o pessoal um pouco mais novo, que tem mais facilidade, eu sempre estimulo, no sentido deles utilizarem. Porque às vezes eles não sabem do potencial que tem. E sempre brinco que na minha época não existia essas facilidades que eles têm hoje, né? Mas, de qualquer forma, eu uso direta e indiretamente, dentro das minhas possibilidades ali.

Pesquisador: Mas em alguma atividade prática em oficina, ou atividade de atendimento ao aluno?

Prof. Vinícius: Prática, diretamente ainda não tentei, mas uso muito no sentido de colher material, né? Até material visual. Mesmo sendo a disciplina de Língua Portuguesa, é possível você trabalhar, sobretudo com as redes sociais, até no sentido humorístico, cômico da língua. 
Pesquisador: E você acha que há dificuldades para a promoção de práticas que fazem uso das TDIC?

Prof. Vinícius: Acho até que não. É um sistema diferenciado de ensino, a gente tem o atendimento na sala. Mas eu acho que o que está proporcionando, na medida do possível, uma sala de informática, eu acho que há possibilidade dessa prática. E há professores que até trabalham diretamente, como você falou, nessa linha de usar diretamente, por exemplo, dinâmicas ali, virtuais. Muitos que já utilizam, né? É uma questão até de, na minha área mesmo tem professores que utilizam em algumas oficinas, fazem ações que utilizam do computador, de um sistema online.

Pesquisador: Mas você acha que esses professores tem alguma dificuldade em fazer esse uso?

Prof. Vinícius: Acho que a grande dificuldade, no sistema daqui, no sistema regular, sobretudo no ensino público, é a quantidade de alunos e o material, os aparelhos disponíveis. Aqui é um pouco essa questão da circulação do aluno. Você pode até fazer um trabalho mais individualizado, mas aí existe um outro problema que você teria que, se fosse um atendimento individual, aliás, é um atendimento individual, mas do ponto de vista tecnológico, teria que acompanhar o aluno, para estar do lado dele, e nem sempre você tem uma pessoa para fazer um outro tipo, uma contrapartida, um outro tipo de atendimento mais rústico, digamos assim.

Pesquisador: Legal. Você também é professor de escola regular, como já disse. Você integra as TDIC às suas práticas escolares? Você já comentou, mas fala um pouco mais sobre suas atividades lá.

Prof. Vinícius: Então, na escola regular é há uma facilidade maior, quer dizer, há pontos positivos e negativos. O negativo é essa quantidade de alunos. Então, se você for utilizar, por exemplo, tablet ou alguma coisa, sempre tem uma dificuldade, pois não tem número suficiente. Um notebook a escola não disponibiliza. Se você pedir para o aluno trazer, existe um outro problema, a questão social, de repente o aluno tem o objeto furtado e tal. Por outro lado, onde eu trabalho, no município aqui de Praia Grande, tem as lousas digitais que facilitam. Inclusive, elas têm umas plataformas, uns programas que estão instalados lá, que dão muitas possibilidades, em quaisquer disciplinas. Há um senão, que é a questão que está sendo, está tentando se equacionar que é do wifi, da conexão e tal, que é problemática. É sempre um problema.

Pesquisador: Tem um problema de infraestrutura ainda.

Prof. Vinícius: Eu não entendo, mas existe até a questão de espessura de parede que dificulta. Eles estão tentando resolver esta questão. Então, às vezes você fica até com receio de fazer uma atividade online, porque, de repente, você planeja aquela atividade e não está conectado. Ou então você planeja, está realizando a atividade e cai a internet.

Pesquisador: E teve alguma atividade que você planejou para lá e que tentou trazer para o CEEJA?

Prof. Vinícius: Não, pela diferença de sistemas. É que aqui também é diferente, lá eu trabalho com uma faixa de etárias de catorze anos, né? É ensino fundamental regular, você tem que ter um outro tratamento. Não nesse sentido, acho que o foco aqui, que eu trago mais efetivamente nas oficinas e nas palestras, basicamente nas oficinas ou no círculo de leitura. E aí é diferente o nível de alcance, o tipo de objetivo é diferente. 
Pesquisador: A partir do que estudamos no curso "Mídias Digitais na Educação de Jovens e Adultos", qual o papel das TDIC na formação para alunos jovens e adultos?

Prof. Vinícius: Bom, eu, como eu falei, apesar de não ter o domínio, sou de uma geração meio jurássica, né? [risos] Estou tentando superar, mas parece que você já nasce com um déficit, com uma defasagem. Essa geração tem mais facilidade. Então, acho a tecnologia e o uso das tecnologias fundamental, sobretudo porque uma boa faixa, um bom número, uma boa porcentagem dessa clientela, entre aspas, já nasceu, já está envolvida pelas tecnologias, então já tem muita facilidade. Acho muito importante. Vai haver uma ou outra pessoa realmente que, também como eu - por incrível que pareça, a gente é professor, mas encontra pessoas com mais idade que a gente, jovens e adultos até no sentido de terceira idade e tal - e tem também, talvez, a mesma dificuldade. Mas é fundamental, eu acho. É importante. Acho que é irreversível. Até futuramente - não quero pregar isso porque seria o próprio desaparecimento do sistema - mas até um ensino, um professor só como um monitor, um orientador. Não sei se causará, não acredito que causará o desaparecimento do professor, mas a transformação dele.

Pesquisador: Mas você acha que para o aluno da EJA o uso das tecnologias tem uma importância diferente em relação aos alunos da escola regular, que já estão mais próximos delas?

Prof. Vinícius: Eu acho que sempre contribui. Sempre contribui por causa disso, pois já uma boa parte desses alunos já são dessa geração. Então, é o que possibilita a eles como forma de informação, de atividades virtuais, atividades online, né? Os que trabalham, sobretudo, eles trabalham, então, no ambiente de trabalho eles podem, tendo um aparelho, um note ou alguma coisa, lá dentro das possibilidades do trabalho, com auxílio do chefe ou alguma coisa assim, sempre está tentando resolver alguma coisa, fazer um curso. Às vezes até meio quebrado, mas acho que é sempre vantajoso.

Pesquisador: Considerando o curso "Mídias Digitais na Educação de Jovens e Adultos", quais são os pontos fortes que devem ser mantidos e que aspectos você identifica como fragilidades, que devem ser alteradas numa segunda oferta da formação?

Prof. Vinícius: Não, eu acho que o formato foi interessante. Teve uma parte prática, né?

Pesquisador: Teve.

Prof. Vinícius: Então, a parte prática, pra gente que tem dificuldade, é sempre necessária uma repetição, um reforço. Mas acho que associas o estudo de textos, houve estudos de textos, conhecer os especialistas da área é importante, as pessoas que estão aí nos estudos sobre tecnologia ou sobre o uso das tecnologias, não é isso? É sempre importante a parte teórica. E mostrar alguns caminhos, mas não oferecer respostas, mas oferecer e mostrar caminhos de utilização das tecnologias. Associar um pouco, né? Propor, né? Juntamente com o ensino teórico, com o estudo teórico, desculpe, umas atividades, mostrar uns caminhos, plataformas, possibilidades. Eu acho que o formato foi bastante proveitoso em tudo que foi feito.

Pesquisador: Quais são as necessidades de profissionalização para implementar a integração das TDIC na sua prática professoral? O que falta?

Prof. Vinícius: O correto seria eu fazer uns cursos, né?

Pesquisador: Formação?

Prof. Vinícius: Sim, formação. O problema, não sei se cabe dizer porque é um caso particular, é que, como eu trabalho em duas instâncias, é meio complicado. Pode ser feito em 
um fim de semana e tal, mas a gente fica cansado da lide diária, é mais complicado. Mas eu acho que a formação é necessária permanentemente, né? Não tem outra possibilidade. Você tem alguns caminhos e a renovação permanente desses caminhos, com cursos, novas formas e novas plataformas.

Pesquisador: Que noções e temas ficam para você a partir da leitura dialogal dos textos ao longo do curso "Mídias Digitais na Educação de Jovens e Adultos"?

Prof. Vinícius: Eu não me recordo dos temas. Você não pode me lembrar?

Pesquisador: Discutimos inclusão digital, empoderamento, recursos educacionais abertos.

Prof. Vinícius: Então, essa questão da inclusão digital é interessante. Porque, não sei, no nosso caso aqui, em nosso tipo de atividade, por incrível que pareça, a gente ainda encontra pessoas que não tem acesso, que tem dificuldade, às vezes até por uma questão financeira. Então, essa ampliação por esse sistema de conexão aberto, wifi, acesso público. Seria interessante ampliar esse serviço. Um país como o Brasil que em todas as instâncias tem dificuldades, tem limitações.

Pesquisador: E você vê possibilidade de implementar uma ação de inclusão digital aqui no CEEJA?

Prof. Vinícius: Individualmente? Acho que sim. Eu acho que algumas, me parece assim uma ação pequena, mas o fato de haver uma sala, ainda que pequena, com computadores de livre acesso para os alunos é muito importante. Eles têm cada vez mais utilizado. Os que não sabem, por serem novos na escola, a gente acaba apontando e eles vão e gostam, eles acham interessante e eles tem utilizado. Eu acho que isso falta até em níveis, assim, locais, né? Não sei se é possível em nível de Brasil, locais públicos assim, não lanhouses, locais públicos de acesso. Ainda existem realmente pessoas que não tem esse acesso em casa.

Pesquisador: Última. Tem algum outro aspecto a respeito do curso que não tenha sido perguntado até agora e que você queira comentar?

Prof. Vinícius: Não. Eu acho que a questão da educação de jovens e adultos no Brasil, acho que é sempre um pouco renegada. E eu acho que, nesse sistema aqui nosso de eliminação de matérias, na EJA em geral, mas esse sistema é extremamente interessante. Eu que não tinha essa experiência aqui, que já vem de muitos anos. Então acho que você abordar a tecnologia para a EJA, sobretudo para esse tipo, essa modalidade de ensino de eliminação de matérias é interessante, porque como você conciliar, como você aplicar programas duradouros produtivos para alunos em que há um rodízio, uma rotatividade. Então como você aplicar isso, viabilizar, conseguir ter bons resultados, oferecer para eles isso aí, para auxiliar na ampliação do conhecimento, do domínio dos assuntos, essa ponte. Acho que esse tipo de curso é relevante.

Pesquisador: E você acharia interessante que acontecesse denovo.

Prof. Vinícius: Eu acho. Acho interessante. Sobretudo eu que tenho limitações. Então é só martelando. É aquele esquema, né? Meio brincadeira, assim. Eu pergunto para minha filha um depoimento meio pessoal. Eu pergunto uma coisa, aí a pessoa explica para você e daqui há quinze minutos eu esqueci. Aí pergunto denovo. E às vezes quem explica, às vezes, não tem a mesma paciência de uma pessoa que está fazendo um curso, que é treinada para aquilo, né? Para dar aquele apoio, para explicar, para reforçar, para oferecer novos caminhos, ações 
diferenciadas para você chegar àquele objetivo. Eu acho que é sempre produtivo. Havendo possibilidade, é interessante.

Pesquisador: Legal. Obrigado, professor!

Prof. Vinícius: Foi tranquilo. Eu que agradeço. 


\section{ANEXO I - ENTREVISTA - PROF. RENATO}

É oportuno observar que a transcrição, na íntegra, dos depoimentos reproduz fielmente a coloquialidade característica da linguagem oral.

Entrevistado: Prof. Renato Pontes (nome fantasia)

Entrevistador: Bruno dos Santos Joaquim

Transcrição: Bruno dos Santos Joaquim

Data: 03 de agosto de 2016

Pesquisador: Agradeço a disponibilidade do coordenador em conceder esta entrevista e contribuir para a presente pesquisa. Os docentes participantes desta pesquisa terão seus nomes mantidos em sigilo, minimizando, desta forma, o risco de exposição dos mesmos. Podemos começar?

Prof. Renato: Podemos.

Pesquisador: Você faz uso de tecnologias digitais no seu dia-dia?

Prof. Renato: Sim. Sim, eu faço.

Pesquisador: Quais?

Prof. Renato: Não sei especificar quais na minha cabeça agora.

Pesquisador: Cite exemplos.

Prof. Renato: Tecnologias que você fala é computador, datashow?

Pesquisador: Sim, mas na sua vida pessoal também, como redes sociais.

Prof. Renato: Todo tempo eu estou ligado a isso. Acho que eu não consigo viver sem tecnologia.

Pesquisador: E na sua vida profissional?

Prof. Renato: Também. Acho que o tempo todo a gente está ligado nisso. Acho não, estamos. Agora mesmo eu estava falando para você do Google Drive, que não estava atualizando. Por que? Porque tem umas provas que estão ali e eu queria sentar lá embaixo para fazer. Como o Google Drive não estava atualizando, as provas não foram para lá. É isso.

Pesquisador: Então o google drive é um exemplo.

Prof. Renato: É um exemplo de tecnologia que eu uso na minha vida.

Pesquisador: Os professores do CEEJA fazem uso de tecnologias digitais nas suas práticas pedagógicas aqui no CEEJA?

Prof. Renato: Da mesma forma que eu faço uso da tecnologia no nosso trabalho, a gente tem feito trabalhos com eles usando o tempo todo a tecnologia.

Pesquisador: Então cita alguns exemplos para mim.

Prof. Renato: Eu utilizo durante os trabalhos de reuniões com os professores, com todos os segmentos. E procuro direcionar também esse trabalho para as atividades com alunos, no acompanhamento das atividades com alunos e professores. Alguns recursos, áudio, vídeos. Por exemplo, nos últimos tempos demos continuidade aquela questão da montagem dos 
vídeos dos professores. Seria isso também? Eles tiveram a formação. Começou o ano passado? Não me lembro.

Pesquisador: Não. Começou este ano.

Prof. Renato: Este ano começou. Daí a PCNP de tecnologia veio na escola, ela deu aos professores uma formação pautada no uso do Windows Media. Daí os professores, depois de um tempo, eles montaram aula encima da proposta. Logo após ela veio e foi apresentado a ela essas aulas, as vídeo-aulas que eles montaram. Então, quer dizer, demos início aí a este trabalho. $\mathrm{Na}$ verdade a gente plantou uma sementinha. $\mathrm{O}$ resultado que virá com o tempo, ainda é algo que a gente não tem uma - como eu posso dizer? - não tem uma previsão do que vai acontecer num todo. A exposição destes trabalhos de vídeo-aulas, nos primeiros trabalhos apresentados eles tiveram uma repercussão boa, até por parte dos professores que estavam vendo, cada um estava gostando. Então ficou claro que os professores conseguiram compreender com muita facilidade como se faz. Eles tiveram entendimento de que isso facilita o trabalho com alunos. E também um entendeu o outro: o professor de língua portuguesa entendeu o que o professor de biologia estava falando, o professor de ciências entendeu o que o professor de inglês estava demonstrando. E isso, levando para o aluno, chegamos a conclusão de que as vídeo-aulas contribuem bastante para a formação dos nossos alunos.

Pesquisador: Os professores receberam bem a proposta, então?

Prof. Renato: A gente até teve uma certa resistência, né? Na idealização das vídeo-aulas. Mas quando eles viram o material das outras disciplinas, aí acho que deu uma quebrada nessa resistência inicial. Talvez a resistência do uso da imagem, não do uso, de não querer se expor, da vergonha, talvez, de não querer se expor. Eu vejo mais por esse lado. Então, por exemplo, no caso de uma vídeo-aula, eu percebi que, talvez, a resistência tenha sido no caso do uso da imagem em si, vergonha mesmo. É mais nesse sentido, e não no sentido de não querer, de dizer: não quero fazer isso, pronto e acabou.

Pesquisador: E este trabalhou contribuiu de que forma?

Prof. Renato: Acho que é importante este tipo de atividade, porque para o aluno passa a ser uma atividade diferenciada. Então, como o aluno daqui tem uma faixa etária diferenciada, na época em que ele estudou não tinha nada disso. Então, a partir do momento que ele frequenta a escola tem uso dessas tecnologias, para ele é uma novidade e acaba sendo um atrativo. E, de certa forma, eles já usam a tecnologia também. No caso o próprio material sugere as vídeoaulas, aí eles necessitam dessas tecnologias. Por que? Porque é uma forma de estudo deles. É um estudo, uma escola de presença flexível, onde a questão de acesso ao conteúdo, à teoria, muitas das vezes o aluno tem que fazer de forma individual, ele tem o auxílio do professor sim, mas em grande parte do tempo ele pode estar de frente com esse conteúdo individualmente. Aí a questão dos vídeos vem ao encontro dessa necessidade deles de, talvez, com o uso da tecnologia, ampliar os horizontes e o acesso ao conhecimento, facilitar o acesso a esse conhecimento. Tem alguns vídeos dos professores, acho que uns dois ou três, que já está publicado, tem um no blog e outro no Youtube. Eu acredito que a partir do momento em que eles se verem de frente com um material do professor, talvez eles se sintam mais ainda, tenham mais facilidade ainda de acesso a esse conhecimento. Eu penso dessa forma, né? 
Pesquisador: Legal. Para além dos vídeos. As vídeo-aulas são um exemplo de trabalho com tecnologias. Você acha que há dificuldades para a promoção de práticas aqui no CEEJA em que os professores façam uso das TDIC?

Prof. Renato: Eu acredito que aquela minha fala inicialmente, sobre a resistência. Ela talvez exista, mas quando você mostra para o professor que não existe tanta complicação assim, acredito que a resistência maior é naquele sentido que eu disse, a vergonha de aparecer, de se expor, ou a questão de não querer sair de uma zona de conforto. Talvez esteja aí a resistência, mas quando eles percebem que não é tão complicado assim, por exemplo, de usar, eles visualizam e veem que a coisa não é tão difícil. E também, Bruno, tudo se dá através de um processo. Não dá para eu, coordenador, chegar na escola e falar: olha, no próximo ATPC a gente vai montar vídeo-aulas. Então existe todo um processo, tem que mostrar a importância, o objetivo do uso do vídeo ou de qualquer outra tecnologia e recurso. Tem que fazer um trabalho de formação continuada com os professores para conhecerem os recursos que a máquina oferece, para que ele tenha conhecimento, para que ele tenha essa facilidade de poder executar o trabalho. Não é um trabalho que dá para ser feito de um dia para o outro. Precisa ter o que? Uma formação continuada nesse sentido. Por mais que a gente saiba que tem professores que dominam muito bem, por outro lado tem aquele que não tem muito domínio. Então a troca de informação entre a pessoa que está fazendo a formação e até mesmo o professor que está ali, que às vezes supera a expectativa de quem está fazendo a formação continuada, vai estar interagindo e o professor vai estar se familiarizando com a situação, com a novidade, e vai ficando mais fácil de executar.

Pesquisador: Então são essas duas dificuldades apontadas: primeiro a questão da resistência por parte do grupo e segundo a questão da formação.

Prof. Renato: Eu acho que a resistência por uma parte do grupo é justamente a dificuldade em estar conhecendo os usos da tecnologia do computador ou outro equipamento, entendeu? É por pouca informação. Aqui não tem aquela resistência: ai, eu não quero fazer isso porque isso e chato. Não é isso. É que tem sim aqueles professores com dificuldade, que não se sentem preparados. Por isso que eu falo da falta de formação. E desde o ano passado a gente já vem fazendo essas formações, Bruno. A gente vem introduzindo essa questão do uso da tecnologia. Acho que essa é, inclusive, uma preocupação da escola há bastante tempo. A nossa característica de escola permite que cada professor traga seu notebook, que monte suas provas, seus materiais, selecione vídeos e tudo mais para os alunos, incentivo à pesquisa. É que agora a gente faz mais, é mais organizado isso agora. Isso é formação todos os dias: facilitar o trabalho do professor com tecnologias, para ele ver que o bicho não é tão feio assim. A gente faz isso, facilitar o dia-dia dele com o computador, com o site, com as oficinas.

Pesquisador: Em 2015 nós realizamos o curso em ATPC "Mídias Digitais na Educação de Jovens e Adultos". A partir do que foi discutido, qual o papel das tecnologias para os alunos jovens e adultos?

Prof. Renato: Facilitou bastante para que, a partir dessa formação feita nos ATPC, os professores começaram a trabalhar com os alunos na sala de informática. Então, hoje o professor direciona o aluno e ele começa a mostrar, a explorar a internet, podendo fazer a abordagem de vários conteúdos de forma diferenciada, uma forma mais lúdica. Uma 
aprendizagem que ele não consegue ter durante uma orientação, às vezes ele pode ter com a visualização de uma imagem, um site, uma prática, mesmo que seja visual, ele vai absorver melhor. Então, eu entendo que, a partir disso, houve mais essa familiarização do professor e do aluno em relação aos computadores da escola. Eles passaram a ser mais utilizados.

Pesquisador: Então, as tecnologias facilitam a aprendizagem? Qual o papel dela além disso?

Prof. Renato: Em relação à formação do aluno, ele busca as informações de uma forma mais rápida. Entendeu? A fonte de pesquisa é muito rápida. Ao invés de ele ir para a biblioteca e ficar consultando um livro, ele pode usar um site de pesquisa. Então, para ele isso é motivador, porque a informação, aquilo que ele precisa, vem de forma mais rápida, aí desperta mais interesse. Ele interage mais com o professor também: professor, olha, eu fiz isso, pesquisei isso, aquela coisa toda. E o papel da escola, nesse sentido, é mostrar para o aluno que existe um mundo muito complexo, muito amplo e complexo, e que a escola tem que buscar mostrar para esse aluno que de tão grande que é esse universo, esse mundo da informática, da internet, do mundo virtual, que ele tem que ter, a partir da escola, um discernimento de como caminhar nessas pesquisas. Porque ao mesmo tempo em que essa pesquisa é rápida, ela pode não ser tão verdadeira quanto parece ser. Então, a escola, eu acho, tem essa função, ao mesmo tempo em que o mundo da internet esta cada vez mais inerente, cada vez mais interligado. Eu não sei, não consigo imaginar o mundo em que ela deixa de existir, eu consigo imaginar um mundo em que ela se torne muito mais complexa. E a escola, nesse caminho de transição do homem entrando, cada vez mais, para o mundo virtual porque nós estamos em uma fase de transição, eu acredito, a internet está no início daquilo que ela virá a ser no futuro - a escola é fundamental para que todos nós tenhamos uma entrada, digamos assim, nesse mundo, de uma forma um pouco mais inteligente. Saber usar esse mundo, saber beneficiar, saber se aproveitar desse mundo de forma que venha a beneficiar o homem e não a nos destruir. É nesse sentido.

Pesquisador: Considerando o curso "Mídias Digitais na Educação de Jovens e Adultos", quais são os pontos fortes que devem ser mantidos e que aspectos você identifica como fragilidades, que devem ser alteradas numa segunda oferta da formação?

Prof. Renato: Os pontos frágeis, penso assim, acho que cada professor deveria ter seu notebook durante a formação. Nem todos têm. O número de computadores na escola devia ser maior e o espaço físico também. Assim, o curso fica prejudicado, porque não dá para explorar mais isso. Pela quantidade de alunos e de professores que nos temos na escola, não consegue atingir a totalidade. Então poucos alunos, poucos professores, utilizam, fazem uso dos computadores. Mas isso já mudou bastante em relação aos anos anteriores. A gente observa hoje tem mais alunos procurando os computadores. E em relação aos professores, também. Inclusive, muitos compraram computadores justamente para estar fazendo um trabalho aqui. Acho que isso é um ponto positivo. Mas ainda falta. Falta recurso, falta uma lousa interativa digital, que para nossa modalidade de ensino seria interessante, entendeu? Por exemplo, outro ponto que é frágil, e que seria interessante ser fortalecido, é, talvez esteja muito além do alcance ainda, mas seria que todos utilizassem de recursos pessoais e que o Estado pudesse proporcionar para eles o acesso a internet. Então, por exemplo, na nossa sala de informática nós temos cinco ou seis computadores, mas, de repente, se existisse um sinal que o aluno tivesse acesso, não sei de que forma poderia ser para ter controle, mas que ele pudesse trazer 
sua maquina, seu celular e tablete para a escola, sentasse no pátio e, enfim, se ele tivesse acesso sem necessariamente precisar da sala de informática. Da mesma forma que ele usa o RA dele para acessar o computador, poderia usar também. Agora, tudo isso, respeitando sempre a característica desta escola, porque na escola regular o trabalho é diferente daqui, você sabe disso.

Pesquisador: Mas voltando à pergunta, pensando especificamente no curso, pensando na maneira como a gente montou e organizou. Como você avalia?

Prof. Renato: O ponto forte que eu avalio positivamente é que, de certa forma, nós vencemos muitos obstáculos desde que iniciou o nosso incentivo ao uso das tecnologias, ao mundo da informática, ao mundo virtual, enfim. Nós temos casos de professores aqui que há cinco anos atrás não sabia nem ligar um computador e hoje consegue sentar na frente dele e digitar, consegue fazer o mais simples trabalho da nossa escola, por exemplo, digitar uma nota no sistema. Quer dizer, foi positivo, porque nós demos o incentivo para que muitas pessoas que nem conseguiam adentrar a esse mundo, agora deram seus primeiros passos. Depois da formação, o que a gente percebe também é que eles conseguem utilizar as tecnologias e reforçar as práticas dos alunos ao mesmo tempo. Então hoje eles fazem questão de usar aquela sala, porque aquela sala está preparada par usar vídeo, usar outros recursos na oficina, que vão ajudar na atividade que os alunos vão fazer depois da apresentação. Então, por exemplo, os professores de química fizeram uma atividade de produção de sabão usando óleo. Antes disso, eles utilizaram datashow, pesquisaram na internet um vídeo que falasse sobre a reação, sobre o que acontece, entendeu? Não foram só para a parte prática direto. As tecnologias ajudaram a fundamentar a coisa toda.

Pesquisador: E você avalia que a adesão dos professores ao uso das TDIC está acontecendo, então?

Prof. Renato: Eu acho. Acho que eles estão juntando mais. Todas as atividades que eram feitas sem uso de tecnologias, hoje eles estão mesclando e criando coisas novas. Estão mostrando de uma outra forma agora. Tanto tem aumentado que nós estamos até investindo mais em aparelhos de tecnologia, porque quando usa muito, quebra mesmo. Todos estão usando, física, biologia, química, até português, que antes tinha mais resistência. Na última oficina que [nome suprimido] fez ele usou as mídias, eu assisti. Eles liam um texto, discutiam e assistiam a alguns vídeos que traziam novas informações para a discussão. Foi muito bom, muito interativo. E isso é um avanço. Mas é depois de todo esse trabalho. Aquela resistência inicial vem sendo superada. Antes a oficina era escolher um texto legal, uma imagem legal para que os alunos participassem das discussões, das reflexões, agora, depois principalmente dessa formação do ano passado, eles começaram, como eu já falei, a experimentar. Eles fazem o mesmo, mas com maior interação, maior atenção dos alunos. A qualidade do trabalho é a mesma, mas ele é mais próximo do aluno agora. Estou falando a partir do que eu vi e eu vejo.

Pesquisador: Há algum outro aspecto a respeito do curso que não tenha sido perguntado até agora e que você queira comentar?

Prof. Renato: Por exemplo, a disciplina de matemática fazia atividades práticas, muitas. Usavam Torre de Hanói, usavam outros jogos. Percebi que depois disso veio o supermercado virtual, teve essa outra que você participou, que você disse que foi legal. Só para citar 
algumas consequências do ponto de vista da coordenação. Mudaram algumas ações, algumas oficinas, enfim. Próximo.

Pesquisador: Acabou. Era só isso. Muito obrigado.

Prof. Renato: Ficou bom? De nada.

Pesquisador: Ótimo, muito obrigado. 


\section{ANEXO J - PARECER DO COMITÊ DE ÉTICA E PESQUISA - UNIFESP}

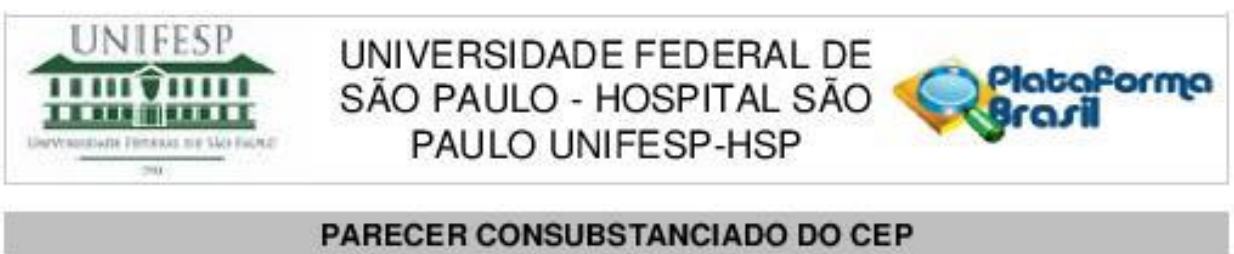

DADOS DO PROJETO DE PESQUISA

Título da Pesquisa: As tecnologias digitais da informaçăo $e$ comunicaçăo na educaçăo de jovens e adultos: estudo de caso de uma formaçăo continuada em serviço de professores de um CEEJA para integrar as mídias digitais à prática pedagógica

Pesquisador: Bruno dos Santos Joaquim

Area Temática:

Versăo: 1

CAAE: 53375315.2 .0000 .5505

Instituiçăo Proponente:Universidade Federal de Săo Paulo

Patrocinador Principal: Financiamento Próprio

\section{DADOS DO PARECER}

Número do Parecer: 1.445 .169

Apresentaçăo do Projeto:

Projeto CEP/UNIFESP n:0124/2016

O presente projeto de pesquisa tem por objetivo realizar um estudo de caso educacional que analise os limites e possibilidades de um curso de formaçăo continuada em serviço sobre a integraçăo das Tecnologias Digita is da Informaçăo e Comunicaçăo (TDIC) às práticas docentes. A formaçăo, desenhada para professores de um Centro Estadual de Educação de Jovens e Adultos (CEEJA), intencionou mobilizar os docentes para a inovação de suas práticas, integradas às TDIC, tendo como meta a promoção da inclusão digital e do empoderamento freireano, além de conduzir a açăo para o planejamento e a realizaçăo de oficinas, com uso das tecnologias a partir de uma perspectiva năo instrumental, que leve em conta as especificidades da Educaçăo de Jovens e Adultos e situe os professores como autores de sua prática educativa. Será deserrvolvida análise temática de conteúdo dos depoimentos dos professores participantes do curso em tela coletados em entrevistas semiestruturadas. Também será realizada análise documental do projeto pedagógico da escola, do plano do curso em tela e dos planos de oficinas elaborados pelos professores, ao final do curso de formação: corpus de investigaçăo da presente pesquisa.

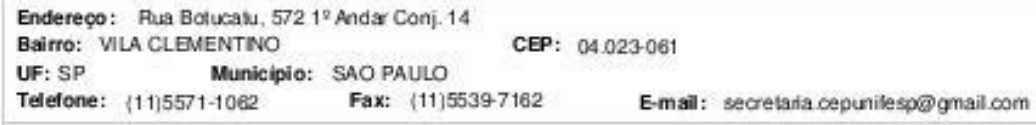




\section{UNIFESP
$\begin{gathered}\text { UNIVERSIDADE FEDERAL DE } \\ \text { IIIIVIIIIIIIIIIIIII }\end{gathered}$
SÄO PAULO - HOSPITAL SÃO Platoforma
PAULO UNIFESP-HSP}

Cortinuagto do Preoor: 1.445 .169

\section{Objetivo da Pesquisa:}

- Hipótese: De que forma um curso de formaçăo continuada em serviço de professores da educação de jovens e adultos para o uso educacional das TDIC, baseado em uma perspectiva năo instrumental pode contribuir para o repensar da prática docente, empoderando os professores, por situá-los como autores de seu cotidiano professoral?

- Objetivo Primário: O abjetivo geral deste estudo é compreender a contribuiçăo de um curso de formação em serviço para professores de um CEEJA para o repensar da prática docente, amparada na utilizaçăo critica das TDIC, de modo a situar os professores em uma perspectiva autoral

-Objetivo Secundário: 1. Contribuir para a discussăo sobre os limites e as possibilidades do uso pedagógico das TDIC na Educaçăo de Jovens e Adultos. 2. Discutir as possbilidades da formaçăo continuada em serviço de professores, valorizando a escola como locus de formaçăo critica e reflexiva. 3 . Refletir acerca das contr buiç̧es dos conceitos de inclusăo digital e do empoderamento, na acepção freireana, para o campo da educação de jovens e adultos.

\section{Avaliaçăo dos Riscos e Beneticios:}

Em relaçăo aos riscos e beneficios, o pesquisador declara:

-Riscos: A presença de um pesquisador na escola coletando informações de documentos, bem como realizando entrevistas, poderá trazer algum tipo de desconforto, pelo fato do mesmo também atuar como professor coordenador na mesma instituiçăo. Nesse sentido, procurar-se-á ser discreto e não interferir com o andamento rotineiro das atividades escolares e procurar deixar clara a diferença do papel do pesquisador e do professor coordenador. Além disso, os docentes que aceitarem participar terăo de disponibilizar certo tempo para que a entrevista seja realizada; nesse sentido, se procurará ser breve com as entrevistas. Uma vez que o nome da escola, bem como dos participantes e o conteúdo dos questianários e entrevistas serăo mantidos em sigilo, o risco de exposição dos mesmos será minimizado.

-Beneficios: Espera-se que esta pesquisa possa promover reflexóes importantes sobre a formaçăo de protessores da Educaçăo de Jovens e Adultos, bem como discutir sobre a importáncia das (re)configuraçóes da prática docente, a partir da reflexăo critica sobre o uso pedagógico das Tecnologias Digitais da Informação e da Comunicação.

\section{Comentários e Consideraçőes sobre a Pesquisa:}

Trata-se de estudo com o objetivo académico de Mestrado, vinculado ao Departamento de

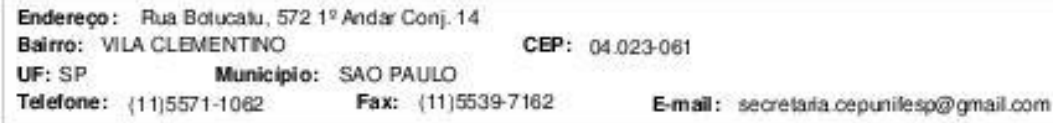




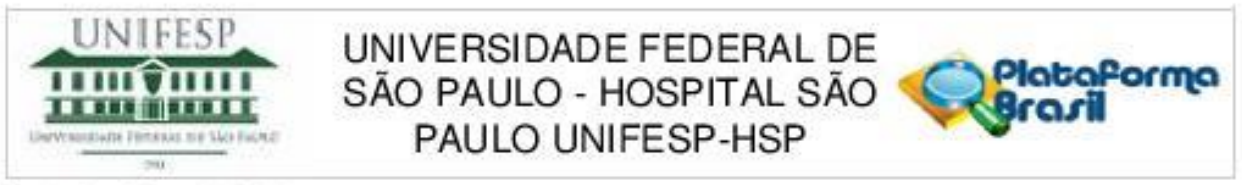

Cortinuagto do Preocer: 1.445 .169

Educaçăo, Campus Guarulhos, com orientaçăo da profa. Luçila Maria Pesce de Oliveira .

TIPO DE ESTUDO: Em busca de argumentaçóes, esta pesquisa qualitativa propõe-se a adotar a metodologia do estudo de caso do tipo educacional, compreendendo que esta pode contribuif para a busca por respostas, na medida em que, como pesquisador e professor coordenador, posiciono-me como objeto e sujeito de pesquisa.

LOCAL:Centro estadual de Educaçăo de Jovens e Adultos (CEEJA)

PARTICIPANTES: participarăo do estudo, seis dentre os 27 professores que fizeram parte dos encontros promovidos pela formação em serviço "Midias Digitais na Educação de Jovens e Adultos“. O critério de seleçăo dividirá os docentes em dois grupos: o primeiro corresponde aos professores que executaram seus planos de oficinas, tendo por base as discussóes promovidas nas ATPC, do qual serăo selecionados trés participantes da pesquisa, um de cada área de conhecimento (a códigos e linguagens, b- cièncias humanas e suas tecnologias, c- ciéncias da natureza e suas tecnologias); o segundo grupo representa os professores que até o momento da seleçăo ainda năo vieram a executar a oficina planejada como atividade de conclusăo do processo formativo, do qual também serăo selecionados um professor de cada grande área do conhecimento.

PROCEDIMENTOS:

Serăo realizadas entrevistas semiestruturadas junto aos docentes. Também fará parte dos procedimentos de pesquisa, a análise documental do Projeto Politico Pedagógico da escola, do plano do curso em tela e dos planos de oficinas produzidos pelos professores como conclusăo do curso.

\section{Consideraçōes sobre os Termos de apresentaçăo obrigatória:}

1. Foram apresentados os principais documentos: folha de rosto; projeto completo; TCLE

2- outros documentos:

a)- autorizaçăo do responsável pela Escola onde será realizado o estudo. (Pasta: Outros- Submissăo 2; Documento:autorização.pdf)

\section{Recomendaçōes:}

Sem recomendaçóes

\begin{tabular}{|c|c|c|}
\hline $\begin{array}{l}\text { Endereço: RLa Bolucalu, } 5721 \\
\text { Bairro: VILA CLEMENTNO }\end{array}$ & Andar Conj. 14 & $04.023-061$ \\
\hline Municipio: & SAO PAULO & \\
\hline Telefone: $\{11\} 5571-1062$ & Fax: $\{11\} 55397162$ & E-mail: secretaria cepunilesp@gnail.com \\
\hline
\end{tabular}




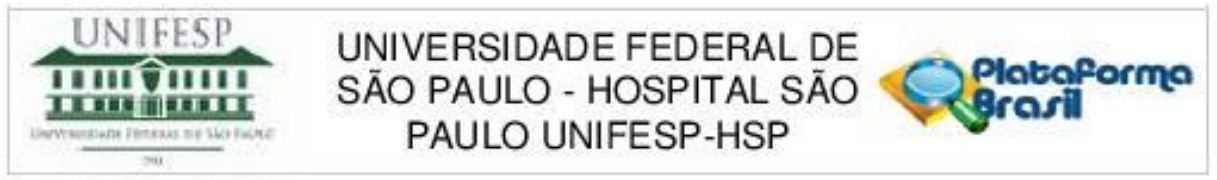

Continuapto do Paroor: 1.445.169

Conclusőes ou Pendências e Lista de Inadequaçōes:

aprovado

Consideraçōes Finais a critério do CEP:

O CEP informa que a partir desta data de aprovaçăo, é necessário o envio de relatórios semestrais (no caso de estudos pertencentes à área temática especial) e anuais (em todas as outras situaçóes). É também obrigatória, a apresentaçăo do relatório final, quando do término do estudo.

Este parecer foi elaborado baseado nos documentos abaixo relacionados:

\begin{tabular}{|c|c|c|c|c|}
\hline Tipo Documento & Arquivo & Postagem & Autor & Situaçăo \\
\hline $\begin{array}{l}\text { Informaçóes Básicas } \\
\text { do Projeto }\end{array}$ & $\begin{array}{l}\text { PB_INFORMAÇOES_BASICAS_DO_P } \\
\text { RONETO 615466.pdf }\end{array}$ & $\begin{array}{l}18 / 02 / 2016 \\
11: 14: 15\end{array}$ & & Aceito \\
\hline Outros & autorizacao.pdf & $\begin{array}{l}11 / 12 / 2015 \\
22: 09: 24\end{array}$ & $\begin{array}{l}\text { Bruno dos Santos } \\
\text { Joaquim }\end{array}$ & Aceito \\
\hline Folha de Rosto & folhaDeRostox.pdf & $\begin{array}{c}11 / 12 / 2015 \\
22: 02: 09\end{array}$ & $\begin{array}{l}\text { Bruno dos Santos } \\
\text { Joaquim }\end{array}$ & Aceito \\
\hline $\begin{array}{l}\text { TCLE / Termos de } \\
\text { Assentimento/ } \\
\text { Justificativa de } \\
\text { Auséncia }\end{array}$ & TCLE_BrunoJoaquim_final.doc & $\begin{array}{c}11 / 12 / 2015 \\
22: 00: 59\end{array}$ & $\begin{array}{l}\text { Bruno dos Santos } \\
\text { Joaquim }\end{array}$ & Aceito \\
\hline $\begin{array}{l}\text { Projeto Detalhado / } \\
\text { Brochura } \\
\text { Investigador }\end{array}$ & Projeto_TrabalhoFinal_final.doc $x$ & $\begin{array}{l}24 / 10 / 2015 \\
13: 29: 50\end{array}$ & $\begin{array}{l}\text { Bruno dos Santos } \\
\text { Joaquim }\end{array}$ & Aceito \\
\hline
\end{tabular}

Situaçăo do Parecer:

Aprovado

Necessita Apreciaçăo da CONEP:

Não

SAO PAULO, 10 de Março de 2016

Assinado por:

Miguel Roberto Jorge

(Coordenador)

Endereco: Rua Bofucals, $5721^{2}$ Ands Conj-14

Bairro: YILA CLEMENTINO

UF: SP MUnicipio: SAO PAULO

Telefone: $\{11\} 5571-1062 \quad$ Fax: (11)55397162 E-mail: secretaria oepunilesp@gnail.oom 